\title{
Special Waste-Form \\ Lysimeters-Arid: Three-Year \\ Monitoring Report
}

\author{
T. L. Jones \\ R. J. Serne \\ A. P. Toste
}

April 1988

Prepared for the U.S. Department of Energy

under Contract DE-AC06-76RLO 1830

Pacific Northwest Laboratory

Operated for the U.S. Department of Energy

by Battelle Memorial Institute 


\title{
DISCLAIMER
}

This report was prepared as an account of work sponsored by an agency of the United States Government. Neither the United States Government nor any agency thereof, nor Battelle Memorial Institute, nor any or their employees, makes any warranty, expressed or implied, or assumes any legal liability or responsibility for the accuracy, completeness, or usefulness of any information, apparatus, product, or process disclosed, or represents that its use would not infringe privately owned rights. Reference herein to any specific commercial product, process, or service by trade name, trademark, manufacturer, or otherwise does not necessarily constitute or imply its endorsement, recommendation, or favoring by the United States Government or any agency thereof, or Battelle Memorial Institute. The views and opinions of authors expressed herein do not necessarily state or refiect those of the United States Government or any agency thereof, or Battelle Memorial Institute.

\author{
PACIFIC NORTHWEST LABORATORY \\ operated by \\ BATTELLE MEMORIAL INSTITUTE \\ for the \\ UNITED STATES DEPARTMENT OF ENERGY \\ under Contract DE-ACO6-76RLO 1830
}

\begin{tabular}{|c|c|}
\hline \multicolumn{2}{|c|}{ Printed in the United States of America } \\
\hline \multicolumn{2}{|c|}{$\begin{array}{c}\text { United States Department of Commerce } \\
5285 \text { Port Royal Road } \\
\text { Springfield, Virginia } 22161\end{array}$} \\
\hline \multicolumn{2}{|c|}{$\begin{array}{l}\text { NTIS Price Cortes } \\
\text { Microfiche An1 }\end{array}$} \\
\hline \multicolumn{2}{|c|}{ Printed Copy } \\
\hline Pages & $\begin{array}{l}\text { Price } \\
\text { Codes }\end{array}$ \\
\hline $001-025$ & A02 \\
\hline $026-050$ & $\mathrm{~A} 03$ \\
\hline $051-075$ & $\mathrm{~A} 04$ \\
\hline $076-100$ & A05 \\
\hline $10 \uparrow-125$ & $\mathrm{~A} 06$ \\
\hline $126-150$ & $\mathrm{~A} 07$ \\
\hline 151.175 & $A 08$ \\
\hline $176-200$ & AOS \\
\hline $201-225$ & A010 \\
\hline $226-250$ & A011 \\
\hline $257 \cdot 275$ & A012 \\
\hline $276-300$ & A013 \\
\hline
\end{tabular}


PNL -6400

UC -70

SPECIAL WASTE-FORM LYSIMETERS-ARID:

THREE-YEAR MONITORING REPORT
T. L. Jones
R. J. Serne
A. P. Toste

Apri 1988

Prepared for the U.S. Department of Energy under Contract DE-AC06-76RLO 1830

Pacific Northwest Laboratory

Richland, Washington 99352 


\section{EXECUTIVE SUMMARY}

Regulations governing the disposal of commercial low-level waste require all liquid waste to be solidified before burial. Most waste must be solidified into a rigid matrix such as cement or plastic to prevent waste consolidation and site slumping after burial. These solidification processes affect the rate at which radionuclides and other solutes are released into the soil. In 1983, a program was initiated at Pacific Northwest Laboratory to study the release of waste from samples of low-level radioactive waste that had been commercially solidified. The primary method used by this program is to bury sample waste forms in field lysimeters and monitor leachate composition from the release and transport of solutes.

The lysimeter facility consists of 10 lysimeters, each containing one sample of solidified waste. Five different waste forms are being tested, allowing duplicate samples of each one to be evaluated. The samples were obtained from operating nuclear power plants and are actual waste forms routinely generated at these facilities. All solidification was accomplished by comercial processes. Sample size is a partially filled 210-L drum. All containers were removed prior to burial leaving the bare waste form in contact with the lysimeter soil.

The waste streams represented in the five waste forms are two boric acid evaporator concentrates, one sodium sulfate evaporator concentrate, and one sodium sulfate evaporator concentrate with spent ion exchange resin added. The solidification agents used were masonry cement, Portland III cement, Dow polymer, and bitumen. The dominant radionuclides contained in the waste are cobalt-60 and cesium-137. Additional radioactive elements include cesium134, manganese-54, and tritium. Total inventory of radionuclides in each sample is in the millicurie range. According to the waste classification system of 10 CFR part 61 , these waste samples would be class A waste.

The hydrologic environment of the lysimeters shows rather large seasonal variations. The volumetric water content at the depth of the waste samples ranges from approximately $11 \%$ in the late winter to a low of about $7 \%$ in the late summer. Drainage rates also vary from winter to summer. The resulting pore water velocities reach a peak of approximately $1 \mathrm{~cm} / \mathrm{wk}$ in the late winter 
and decline steadily to less than $0.05 \mathrm{~cm} / \mathrm{wk}$ in late sumer. Total drainage resulting from natural precipitation was $4 \mathrm{~cm}$ drainage out of $14 \mathrm{~cm}$ precipitation during the 1984-1985 climatic cycle, and $12 \mathrm{~cm}$ drainage out of $24 \mathrm{~cm}$ precipitation during 1985-1986.

Two radionuclides have been found in lysimeter leachates to date. Cobalt60 has been found in five lysimeters. The total amount of cobalt-60 leached to the bottom of the lysimeters is $<0.1 \%$ of the total inventory. This total amount is small but interesting because laboratory sorption studies indicate that cobalt-60 should be highly sorbed onto soil clays and therefore no measurable quantities should leach to the lysimeter drain. The presence of this small amount suggests that leaching of a small but highly mobile fraction of cobalt-60 has occurred. It is likely that the formation of organic complexes between cobalt-60 and organic chelating agents found in the waste is responsible for the cobalt-60 mobility. The second radionuclide found in lysimeter leachate is tritium. Tritium is only found in one of the waste forms being tested, but is found in the leachate from both lysimeters containing these samples. Tritium leached to the lysimeter drain is about $30 \%$ of total tritium inventory.

Analysis of the lysimeter leachates extends beyond identifying radionuclide content. A complete chemical inventory of leachates is made on a quarterly basis. Results of these analyses reveals migration of other constituents of the waste in addition to radionuclides. High amounts of sodium, sulfate, boron, calcium, and magnesium are found in various waste forms. All of these major components are found in the respective leachate samples. A complete quantitative analysis of these leachates will require extensive geochemical and transport modeling; however, sone qualitative trends have been identified. It appears that much of the sodium being released from the sodium sulfate wastes is displacing calcium from the soil and then replacing calcium on the soil exchange sites. This results in excess calcium appearing in the leachates and sodium levels being lower than anticipated. It also appears that the release of boron from the boric acid waste forms is being retarded to a significant degree. In the boric acid/masonry cement waste form, the retardation mechanism may be a solubility control with boron precipitating with cement solid phases. In the case of the boric acid/bitumen waste form the mechanism may be physical entrapment of the boron inside the bitumen structure. 
The program has collected extensive hydrologic and chemical data over the last 3 years relating to the leaching of commercial waste forms under field conditions. At this point, the analys is has been largely qualitative and speculative. The final phase of the program will rely extensively on the iterative process of model simulation and model calibration to provide quantitative interpretation to the existing data. However, preliminary analys is of the data indicates that these data will allow a more definitive analysis of source terms associated with commercial low-level waste than is possible with laboratory data alone. 
$a$ 


\section{ACKNOWLEDGMENTS}

The authors wish to acknowledge the support of Marcia Walter, Virginia LeGore, Stephanie McLaurine, Clark Lindenmeier, and Paula Heller for their help in collecting and managing the data contained in this paper.

The authors would also like to acknowledge the invaluable help of

Dr. Peter Colombo of Brookhaven National Laboratory (BNL). Dr. Colombo and his staff were responsible for obtaining all samples of commercial waste used in this study. This was a difficult task both technically and logistically and we express our appreciation to Peter. BNL also performed the original chemical characterization of the waste streams. 


\section{CONTENTS}

EXECUTIVE SUMMARY ......................... . . ... i i

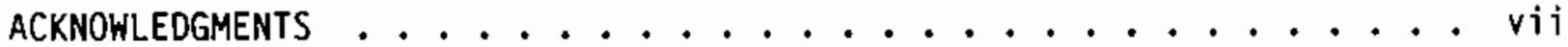

1.0 INTRODUCTION . . . . . . . . . . . . . . . . . . . . . . . . . . .

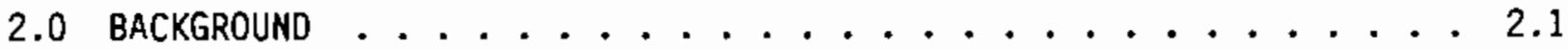

2.1 DESCRIPTION OF LYSIMETER FACILITY . . . . . . . . . 2.2

3.0 DESCRIPTION OF WASTES SOLIDIFIED AND PLACED IN THE LYSIMETERS . . . 3.1

3.1 ANALYSIS OF LIQUID WASTE STREAMS . . . . . . . . . . . 3.1

3.1.1 Boric Acid Waste $\# 1$.............. 3.3

3.1 .2 Boric Acid Waste $\# 2$. . . . . . . . . 3.4

3.1.3 Sodium Sulfate Evaporator Concentrate . . . . . . 3.7

3.1.4 Evaporator Concentrate With Ion Exchange Resin . . . 3.8

3.2 CALCULATION OF RADIONUCLIDE INVENTORY IN EACH DRUM . . . . 3.9

3.2.1 Drums 4-1B and 4-2B .............. 3.11

3.2.2 Drums $\# 1$ and $\# 2$................. 3.14

3.2.3 Drums $1-1 \mathrm{~B}$ and $1-2 \mathrm{~B} . . . . . . . . . . . .3 .14$

3.2 .4 Drums $2-1 B, 2-2 B, 2-3 B \ldots . . . . . . . . .3 .15$

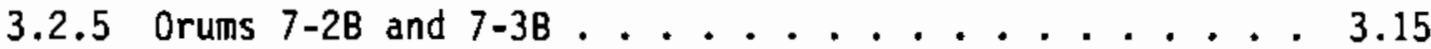

3.3 CALCULATION OF CHEMICAL INVENTORY IN EACH DRUM $\ldots . . . . .3 .16$

4.D LYSIMETER HYDROLOGY . . . . . . . . . . . . . . . . . . 4.1

4.1 SOIL HYDRAULIC PROPERTIES . . . . . . . . . . . . 4.1

4.2 LySimeter WATER BALANCE . . . . . . . . . . . . . 4.4

4.3 WATER balance Parameters RElevant to tRansport . . . . . . . 4.15

5.0 WASTE-FORM LEACHING RESULTS . . . . . . . . . . . . . . 5.1

5.1 RADIONUCLIDE MIGRATION . . . . . . . . . . . . 5.1

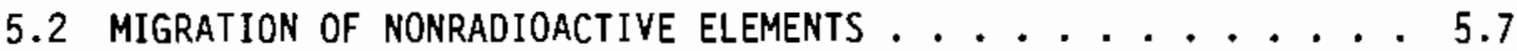




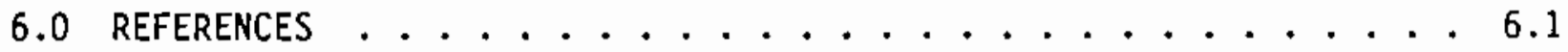
APPENDIX A - DETAILED ORGANIC ANALYSIS OF COMMERCIAL REACTOR WASTE

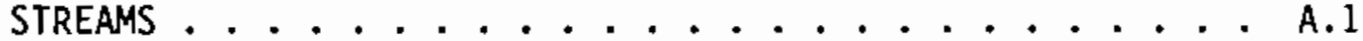
APPENDIX B - SOIL-WATER CONTENT OF LYSIMETERS MEASURED BY

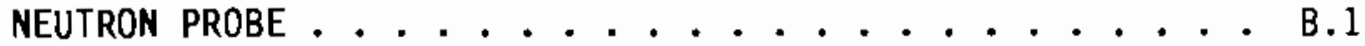
APPENDIX C - FIELD RADIOCHEMISTRY DATA ............. C.1 APPENDIX D - ChEMICAL ANALYSES OF LEACHATES . . . . . . . D.1 


\section{FIGURES}

2.1 Schematic of Lysimeter Facility . . . . . . . . . 2.3

4.1 Water Retention and Hydraulic Conductivity Curve for

Lysimeter Soil ................. . 4.2

4.2 Initial Water Content Profile for Lysimeters 1, 4, 7, and 9...4.5

4.3 Profile Water Storage for Lysimeters 1,4 , and $7 \ldots . . . .4 .6$

4.4 Cumulative Drainage for Lysimeters 1,4 , and $7 \ldots 4 . \ldots$

4.5 Water Content Profile for Lysimeters $1,5,6$, and 7 for $9 / 25 / 84 \ldots \ldots \ldots \ldots . \ldots . \ldots . \ldots . \ldots$

4.6 Profile Water Storage for Lysimeters, 1, 5, and 6...... 4.10

4.7 Cumulative Drainage for Lysimeters 1, 5, and $6 \ldots 4.11$

4.8 Profile Water Storage for Lysimeters 1, 5, and $8 \ldots \ldots . . \ldots 43$

4.9 Cumulative Drainage for Lysimeters, 1, 5, and $8 \ldots \ldots$. . . . 4.14

5.1 Cumulative Release of Tritium from Lysimeters 1 and 7 Versus Time ................... 5.2

5.2 Cumulative Release of Tritium from Lysimeters 1 and 7 Versus Cumulative Drainage .............. 5.4

5.3 Cumulative Release of Cobalt-60 from Lysimeters $2,3,4$,

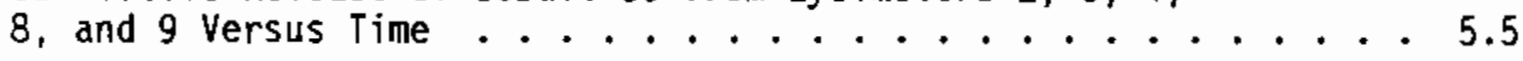

5.4 Cumulative Release of Cobalt-60 from Lysimeters $2,3,4$, 8 , and 9 versus Cumulative Drainage . . . . . . . . 5.6 


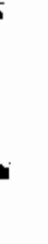




\section{$\underline{\text { TABLES }}$}

3.1 Description of Waste Streams and Solidification Agents Used to Generate Waste Forms Buried in the Lysimeter Facility . . . . . 3.1

3.2 Radioisotope Inventory of Boric Acid Waste \#1 . . . . . . 3.3

3.3 Comparison of BNL and PNL Analyses of Boric Acid Waste \#1

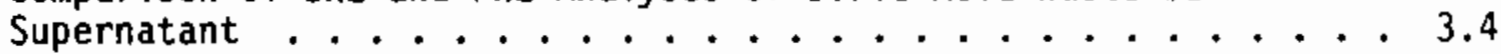

3.4 Chemical Analysis of Boric Acid Waste \#1 Slurry . . . . . . 3.5

3.5 Radionuclide Content of Boric Acid Waste \#2 . . . . . . . 3.5

3.6 Chemical Analysis of Boric Acid Waste \#2 Slurry . . . . . . 3.6

3.7 Radionuclide Content of Evaporator Concentrate . . . . . . 3.7

3.8 Chemical Composition of Evaporator Concentrate Slurry . . . . 3.8

3.9 Radionuclide Content of Evaporator Concentrate Plus Ion Exchange Resin ................ 3.9

3.10 Chemical Composition of Evaporator Concentrate Plus Ion Exchange Resin ................ . 3.10

3.11 Description of Drums . . . . . . . . . . . 3.12

3.12 Decay-Corrected Source Inventories of Radionuclides in Drums . . 3.13

3.13 Process Volumes Selected to Estimate Chemical Inventories . . . 3.16

3.14 Estimated Chemical and Preferred Radionuclide Inventory in Waste Forms ............... . 3.17

4.1 Average Water Balance Parameters for 1984-1986 . . . . . . 4 4.15

5.1 Total Amount of Nonradioactive Elements Leached from Lysimeters . . . . . . . . . . . . . . . . . 5.8 


.

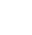




\subsection{INTROOUCTION}

In 1983 the Special Waste-Form Lysimeters-Arid (SWLA) program was initiated to evaluate radionuclide source terms associated with low-level waste being produced and solidified at comnercial power reactors. The research is sponsored by the U.S. Department of Energy (DOE) Low-Level Waste Management Program and is being conducted at the Hanford Site near Richland, Washington by the Pacific Northwest Laboratory (PNL)(a). The objectives of the research program are to: 1) monitor the release of radionuclides from solidified waste forms under field conditions; 2) correlate laboratory estimates of source term and transport with measured field results; 3 ) determine, where possible, the chemical and physical mechanisms controlling source terms and the relative role played by waste form and environment; and 4) make recommendations on how source terms for solidified waste should be characterized and modeled to support a burial site performance assessment. The primary benefit this program will offer to commercial waste management is an experimental evaluation of the validity of available source term models.

The first objective is being met by the construction and operation of a field lysimeter facility where large-scale (210-L drum) samples of solidified waste have been buried in soil-filled caissons since the spring of 1984 . The lysimeters are free of vegetation and only receive natural precipitation. The inventory of the waste forms was measured for each sample before burial. Leaching of the waste forms is currently being monitored through analysis of drainage water collected at the bottom of the lysimeter. Future measurements of leaching will come from exhumation of the waste forms, which will permit remeasurement of radionuclide inventories, together with detailed measurement of radionuclide concentrations within the lysimeter.

The samples of solidified waste being studied in the lysimeter facility were obtained from three commercial power reactors currently operating in the United States. The samples were manufactured as part of routine waste solidification operations at the reactor and with actual waste streams. As such, they represent waste forms routinely produced by the reactors and shipped to

(a) Operated by Battelle Memorial Institute for the U.S. Department of Energy. 
near-surface burial sites. The lysimeter facility contains duplicate samples (individual inventories vary by about 10-15\%) for each of the five waste forms. The waste streams were solidified with agents designed to meet the structural specifications of class $B$ or $C$ waste, although the radionuclide concentrations are well below the upper limit of class $A$ waste set by 10 CFR 61 .

In addition to the lysimeter study, the program also includes laboratory leaching studies and a transport modeling effort. The laboratory leaching studies include traditional water leaching tests such as ANS 16.1 (ANS 1986), soil column leach tests, as well as soil column and batch sorption tests (walter, Graham and Gee 1984). Historically, field performance of solid waste forms has been predicted solely on the basis of these types of laboratory tests. However, the correlation between laboratory leaching results and field performance has not been adequately validated through experimentation. An important objective in this research program is to evaluate predictions based on laboratory measurements by comparison with measurements made in the lysimeter facility.

Modeling will be used extensively to help interpret experimental results and formulate recomendations. The solution chenistry of laboratory and field leachate samples will be analyzed with geochemical models to aid in estimating the speciation component of source terms and to evaluate sorption parameters. Hydrologic models will be used to evaluate the effects of waste form geometry on water contents and flow rates, which are difficult to measure experimentally.

The results of laboratory leaching tests (i.e., estimated diffusion coefficients, adsorption surfaces, etc.) will not be directly comparable to data collected in the field (i.e., leachate concentrations, soil radionuclide distributions, water drainage rates, etc). Thus, hydrologic, geochemical, and dispersive transport models will be used to translate laboratory measured parameters into field measured results. Using the models to make predictions based on laboratory data will clarify which laboratory measurements are most descriptive and which conceptual models of leaching and transport are most effective in predicting field performance.

The remainder of this paper will discuss the design and operation of the field lysimeter facility, and the preliminary results obtained over the past 3 years. The important characteristics of the annual water balance are 
explained together with the relationship between lysimeter hydrology and local soil and climatic conditions. This discussion is followed by a sumnary of radionuclide leaching data and some preliminary observations on the relationship between the site hydrology and leaching history of the waste forms.

Section 2.0 of this report will discuss the technical background of the SWLA program, including the licensing regulations that motivate this program, and a brief description of the lysimeter facility where data presented in this report was collected. Section 3.0 presents a detailed explanation of the waste streams and solidification agents used to generate the waste forms buried in the lysimeter facility. The waste stream chemistry has been characterized in detail and data are presented on waste stream chemistry as well as the total inventory of radionuclides and nonradioactive chemicals contained in each waste form buried in the lysimeters. The hydrology of the lysimeter facility is presented in Section 4.0. This discussion includes a summary of the hydraulic properties of the lysimeter soil material, as well as an explanation of the seasonal patterns of water storage and drainage rates. The chemistry of the lysimeter leachate samples is presented in Section 5.0. The cumulative release of radionuclides is discussed first, followed by a summary of the total amount of nonradioactive chemicals that have leached from the lysimeters. The report is supplemented with four appendices that contain listings of measurements of water contents of the lysimeters and chemical analyses of the lysimeter leachates. 
.

.

:

. 


\subsection{BACKGROUND}

Licensing requirements (NRC 1986) prohibit the near-surface disposal of low-level radioactive waste in a liquid form. Consequently, generators of lowlevel waste, such as commercial power reactors, solidify their liquid waste streams before shipment to a waste disposal facility. A liquid waste is considered solidified if less than $0.5 \%$ by volume remains as a free liquid (NRC 1983). The U.S. Nuclear Regulatory Commission (NRC) has devised a three-tier waste classification system (classes A, B, and C), that guides the solidification process. Class $A$ waste contains the lowest concentration of radionuclides and can be solidified by adding any absorbent, such as sawdust or vermiculite, that will reduce the free liquid content. Class $B$ and $C$ waste contain higher concentrations of radionuclides and must meet additional requirements of stability such as minimum compressive strength, resistance to corrosion, dissolution, biodegradation, and leaching. Therefore, class $B$ and $C$ wastes are commonly solidified with materials such as cement, bitumen or vinyl-ester styrene (i.e., Dow(a) polymer).

The stability requirements are primarily designed to prevent the slumping and subsidence of surface covers that result from compaction and degradation of unstabilized buried waste. However, solidification can also affect the release rate and speciation of radionuclides entering the soil. Understanding these latter effects becomes important when predicting the performance of a buried waste site. A minimum of two performance assessments are required by 1D CFR 61 in the life of a burial site. The first assessment is in the initial licensing process and the second is at site closure. Additional assessments may be required if significant migration of radionuclides is detected during the operational phase. Each assessment includes extensive modeling of radionuclide transport from the waste site by pertinent pathways such as groundwater, air, plants, and burrowing animals.

While these diverse pathways are different in terms of transport mechanisms and modeling strategy, they share a common origin or source: the waste form. To enter any of the pathways, contaminants must first leave the waste form.

(a) Dow-Corning Corporation, Mid1and, Michigan. 
Therefore, the initial modeling step, regardless of the pathway, is to characterize the release of contaminants from the waste form.

There are three characteristics of a waste form that determine its role as a contamination source: 1) the inventory of contaminants contained in the waste form; 2) the chemical speciation of the contaminants being released from the waste; and 3) the tendency of the contaminants to leave the waste form. This latter characteristic differs from the other two in that it may depend as heavily on the burial environment (i.e., soil type and climate) as on properties of the waste form. The tendency of contaminants to leave a waste form may be quantified as a known flux of contaminant at the waste form surface, or as a known solution concentration at some point in the soil profile. Together, inventory, species, and release rate or concentration constitute what in modeling is known as the source term. Any transport calculation, regardless of the pathway involved, must make some assumption about or prediction of the source term associated with the burial site.

\subsection{DESCRIPTION OF LYSIMETER FACILITY}

The lysimeter complex (Figure 2.1) was constructed in the summer of 1983 and consists of 10 soil-filled caissons $(183 \mathrm{~cm} \times 305 \mathrm{~cm})$, placed concentrically around a central access caisson $(365 \mathrm{~cm} \times 365 \mathrm{~cm})$. Each lysimeter contains one waste form sample that has been removed from its $210-\mathrm{L}$ (55-gallon) barrel leaving the waste form in direct contact with the soil. Each lysimeter is equipped with a gravity drain leading to the central access caisson for collection of leachate water. The central caisson also provides access to each lysimeter through horizontal sampling ports. A $15-\mathrm{cm}-d i a m e t e r$ well is installed at the side of each lysimeter to allow downwell gamma-ray scanning and neutron probe measurements of soil water content. Lysimeters are instrumented with thermocouples to measure the vertical soil temperature profile, fiberglass resistance blocks to monitor soil water potential, and suction candles to allow extraction of soil solution samples.

The bottom of the waste sample in each lysimeter is at $250 \mathrm{~cm}$; however, the height of individual samples ranges from 60 to $80 \mathrm{~cm}$. The waste samples were located deep in the lysimeter to minimize the transport distance to the drain (gravel layer), thereby isolating the source term as much as possible. 


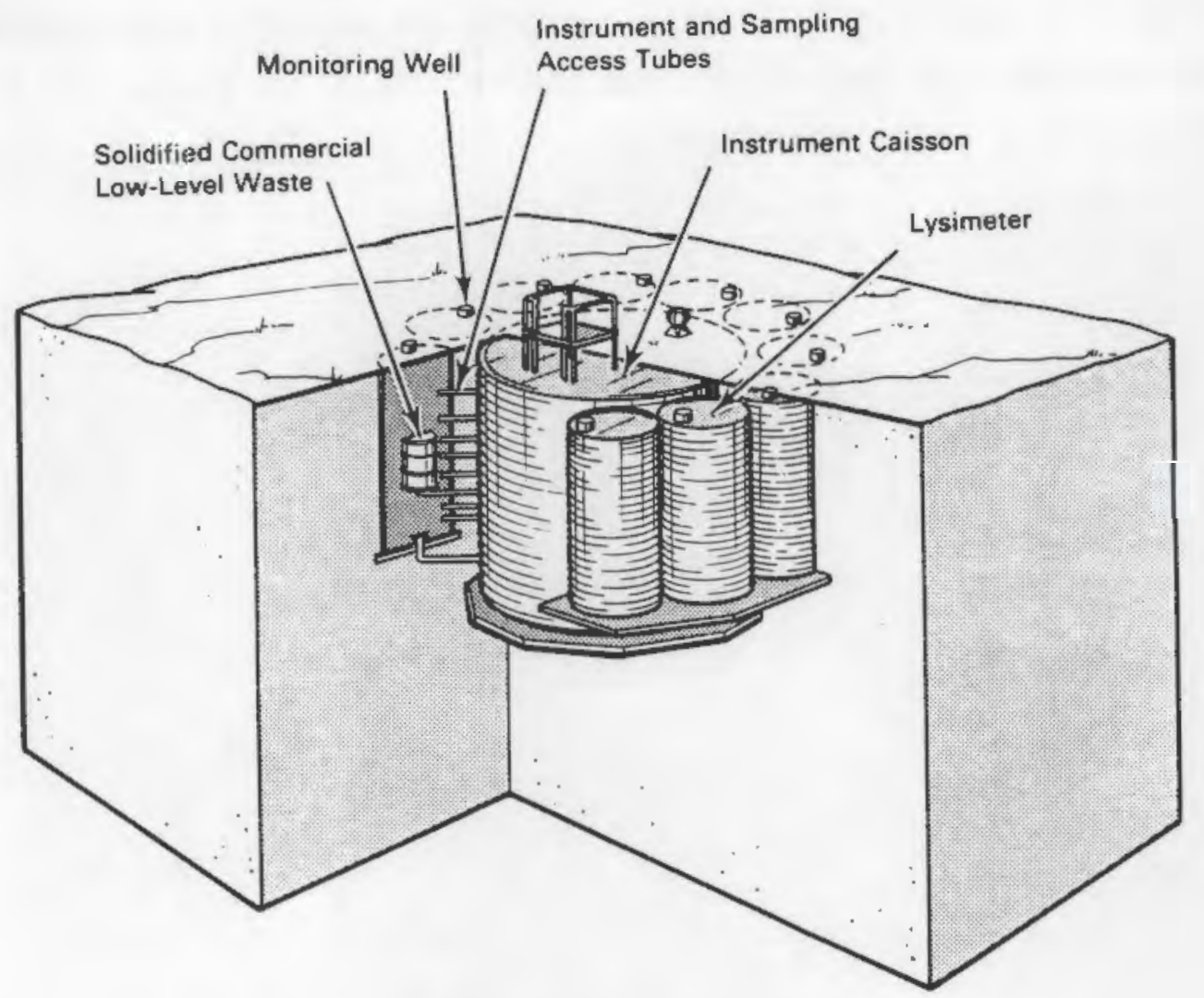

FIGURE 2.1. Schematic of Lysimeter Facility

Fiberglass moisture blocks were placed above the waste samples in an effort to detect ponding of water on top of the sample. Suction candles were placed immediately below the waste and between the waste and the drain to allow samples to be collected along the transport stream. Selected meteorological measurements are made on site and these are supplemented with data from the Hanford Meteorological Station located 30 miles north of the lysimeter facility. A complete description of all instrumentation and their placement is contained in Walter, Graham and Gee (1984).

Eight of the ten lysimeters were filled in March 1984; these included lysimeters 1-4 and 7-10, which contain the waste samples solidified with cement and Dow polymer. The bitumen waste forms were buried in lysimeters 5 and 6 in September 1984. Drainage measurements were made approximately once a month during 1985 and once every 2 to 3 weeks during 1986 and 1987. All drainage samples are analyzed for radionuclides, while a complete cation/anion analys is 
is performed quarterly. Soil water contents are measured approximately twice a month, whereas soil temperature and the soil moisture blocks are monitored continuously by a data logger system. 


\subsection{DESCRIPTION OF WASTES SOLIDIFIED AND PLACED IN THE LYSIMETERS}

Ten samples of five waste forms were buried in the SWLA lysimeter facility. The five waste-forms represent four waste streams and four solidification agents. Table 3.1 shows the combinations of waste stream and solidification agent used to generate the five waste forms. Table 3.1 also lists the lysimeters that contain each of the duplicate pairs of each waste-form. A brief description of the characterization methods used and individual waste forms follows. The acquisition of the waste forms and liquid waste streams was performed by employees of Brookhaven National Laboratory (BNL). Most of the radionuclide analyses and some of the total chemical analyses were also performed by BNL.

\subsection{ANALYSIS OF LIQUID WASTE STREAMS}

Soon after acquisition, the liquid waste streams were analyzed for $\mathrm{pH}$, Eh, percent solids, and gamma emitting radionuclides. For one waste stream, anions were also measured by ion chromatography soon after collection. Three to four years after collection, samples that had been archived were analyzed,

TABLE 3.1. Description of Waste Streams and Solidification Agents Used to Generate Waste Forms Buried in the Lysimeter Facility

\begin{tabular}{|c|c|c|}
\hline Waste Strean & $\begin{array}{l}\text { Solid } \\
\text { Matrix }\end{array}$ & Lys imeter \# \\
\hline $\begin{array}{l}\text { Evaporator } \\
\text { concentrate } \\
\text { (boric acid) }\end{array}$ & $\begin{array}{l}\text { Masonry cenent } \\
\text { Bitumen }\end{array}$ & $\begin{array}{l}1,7 \\
5,6\end{array}$ \\
\hline $\begin{array}{l}\text { Evaporator } \\
\text { concentrate } \\
\left.\text { (Na2 } \mathrm{SO}_{4}\right)\end{array}$ & $\begin{array}{l}\text { Portland III } \\
\text { cement }\end{array}$ & 2,8 \\
\hline $\begin{array}{l}\text { Evaporator } \\
\text { concentrate } \\
+ \text { exchange resin } \\
\left(\mathrm{Na}_{2} \mathrm{SO}_{4}\right)\end{array}$ & $\begin{array}{l}\text { Portland III } \\
\text { cement } \\
\text { Dow polymer }\end{array}$ & $\begin{array}{r}3,9 \\
4,10\end{array}$ \\
\hline
\end{tabular}


after total digestion by acidification, for common cations and anions and selected trace metals. Cations and trace metals were measured by inductively coupled plasma (ICP) spectroscopy and ion chromatography was used to measure the anions. At this time supernatant samples were also characterized for $3 \mathrm{H}$ content and gamma-emitting radionuclides. The $3 \mathrm{H}$ determination was performed by liquid scintillation after distillation in a holdback solution to separate $3 \mathrm{H}$ from other beta enitters. The holdback solution contains high concentrations of stable isotopes of elements, which could have been present as other beta emitters in the waste strean. All gamma analyses performed at BNL and PNL used $\mathrm{Ge}(\mathrm{Li})$, intrinsic Ge and/or NaI detectors. Radionuclide contents are decay corrected back to the date of acquisition April 20, 1983, for boric acid \#1; August 29, 1984, for boric acid \#2; and September 27, 1983, for the evaporator concentrate and concentrate with resin.

For boric acid waste $\# 1$ the ${ }^{90} \mathrm{Sr}$ content was determined by BNL 90 days after waste stream acquisition by adding a stable yttrium carrier to both the supernatant and dry solid. The solid was extracted in $6 \mathrm{~N}$ hot HCl, then filtered to remove solids. The acid extract was extracted with HDEHP, the organic phase was then washed several times with dilute $\mathrm{HCl}$, then yttrium was back extracted into $9 \mathrm{~N} \mathrm{HCl}$. The supernatant and aqueous phases from solids dissolution were purified by methyltricapril ammonium chloride. Yttrium was precipitated as the hydroxide, collected on a filter, dissolved in acid and reprecipitated as the oxalate. The precipitate was collected onto a filter disk by vacuum filtration, dried and weighed to calculate the yttrium carrier yield. The filter disks were mounted on planchets and beta counted on a gas flow Geiger counter. The sample was recounted 2 days later to check the radiochemical purity (in growth of $90 \mathrm{Y}$ with a 64 -hour half-life). The ${ }^{90} \mathrm{Sr}$ was determined by the measured activity of its daughter ${ }^{90} Y$.

A detailed organic analysis was performed on the boric acid \#1, evaporator concentrate, and evaporator concentrate with ion exchange resin beads within 1 year of acquisition. The supernatant and solid fraction of the waste streams were analyzed separately, and two fractions of organic compounds: hydrophobic and hydrophilic, were identified. Details of the analysis procedures and results are included in Appendix $A$. 


\subsubsection{Boric Acid Waste \#1}

This liquid sample was analyzed by BNL 90 days after collection. The sample was brownish pink in color with precipitate present (likely undissolved boric acid). The sample weighed $457.82 \mathrm{~g}$ and had a volume of $437.6 \mathrm{~cm}^{3}$, thus the specific density was 1.046 . The sample was centrifuged untit the supernatant was clear. The centrifuged solids, after drying, weighed $25.31 \mathrm{~g}$. A portion of the supernatant was evaporated to dryness and the dissolved solids content determined, $42.4 \mathrm{~g} / \mathrm{L}$. The $\mathrm{pH}$ and Eh of the slurry was 3.18 and $+690 \mathrm{mV}$. The supernatant had a $\mathrm{pH}=3.20$ and $\mathrm{Eh}=740 \mathrm{mV}$.

The radionuclide content of both the supernatant and dried solid were determined. From the weight of centrifuged solids $(25.31 \mathrm{~g})$ and volume of supernatant liquid $(419.9 \mathrm{ml})$, the activity of the total slurry could also be calculated. The results are shown in Table 3.2.

The solid phase accounted for about $10 \%$ of the total activity in the slurry while accounting for only $5.5 \%$ of the slurry's total weight. Thus, the solids are enriched over the supernatant by a factor of 2. In April 1987, PNL analyzed a sample of this waste stream's supernatant for gamma emitters and $3 \mathrm{H}$. The results are shown in Table 3.3. The PNL values for gamma emitters are about one-half as large as the BNL values. No explanation is offered other than perhaps the residual solids from the PNL slurry may have picked up more radionuclides after 4 years of storage.

TABLE 3.2. Radioisotope Inventory of Boric Acid Waste \#1 (decay corrected to $4 / 20 / 83$ )

Radionuclide Supernatant, $\mu \mathrm{Ci} / \mathrm{L}$ Dry Solids, $\mu \mathrm{Ci} / \mathrm{g}$ Total Slurry, $\mu \mathrm{Ci} / \mathrm{L}$

\begin{tabular}{|c|c|c|c|}
\hline${ }^{137} \mathrm{Cs}$ & $160.0 \neq 0.4$ & $0.31=0.01$ & $170.3=0.4$ \\
\hline${ }^{134} \mathrm{Cs}$ & $92.8 * 0.8$ & $0.18 \neq 0.01$ & $99.2 \pm 0.8$ \\
\hline & $6.3 \neq 0.2$ & $0.02 * 0.002$ & $7.1 * 0.2$ \\
\hline & $1.7 \pm 0.1$ & $0.003 \neq 0.0002$ & $1.8 \pm 0.1$ \\
\hline & $1.8 \neq 0.1$ & $0.003 \pm 0.00001$ & $1.9 \pm 0.1$ \\
\hline & $0.038 \neq 0.002$ & $0.00008 \neq 0.000003$ & $0.045 \div 0.002$ \\
\hline
\end{tabular}


TABLE 3.3. Comparison of BNL and PNL Analyses of Boric Acid Waste \#1 Supernatant (decay corrected to $4 / 20 / 83$ )

\begin{tabular}{|c|c|c|}
\hline & & \\
\hline Radionuclide & BNL & PNL \\
\hline${ }^{137} C_{s}$ & 160.0 & 82.5 \\
\hline${ }^{134} \mathrm{Cs}$ & 92.8 & 50.6 \\
\hline${ }^{60} \mathrm{Co}$ & 6.3 & 3.4 \\
\hline${ }^{58} \mathrm{Co}$ & 1.7 & $<$ \\
\hline${ }^{54} \mathrm{Mn}$ & 1.8 & $<$ \\
\hline $3 \mathrm{H}$ & -- & 70.0 \\
\hline
\end{tabular}

Table 3.4 shows the total chemical analysis values determined by PNL about 4 years after acquisition. The inorganic values represent the total slurry content as the samples were acid digested. The anion determinations performed by BNL 90 days after acquisition are shown in parenthesis in Table 3.4. In the 4 years of storage the anion composition of the waste slurry has remained constant. The waste form is a predominantly sodium borate solution with significant amounts of sulfate, nitrate, chloride, and calcium being present. Details on the organic analys is are found in Appendix A. The total organic carbon value in Table 3.4 arbitrarily assumes carbon constitutes $75 \%$ of the organic matter.

\subsubsection{Boric Acid Waste \#2}

The second boric acid evaporator concentrate waste stream was acquired at the same time two 55-gallon drums of bitumen waste forms were prepared (August 29, 1984). The waste stream sample was approximately $4 \mathrm{~L}$ and consisted of a clear supernatant liquid and two visible precipitates. The density of the slurry after homogenization by stirring was $1.015 \pm 0.007 \mathrm{~g} / \mathrm{mL}$. The supernatant liquid had a pH value of 8.4 and an Eh of $225 \mathrm{mV}$. At the time of acquisition, power plant chemists estimated that the waste stream contained $4.9 \%$ suspended solids (similar to the $5.5 \%$ calculated for boric acid evaporator concentrate waste \#1). An aliquot of the slurry was redissolved in concentrated nitric and hydrochloric acid. The acid digest was analyzed for gamma radionuclides. Table 3.5 gives the results in terms of microcuries per liter of original slurry. For comparative purposes, PNL measurements made 32 months 
IABLE 3.4. Chemical Analysis of Boric Acid Waste \#1 STurry

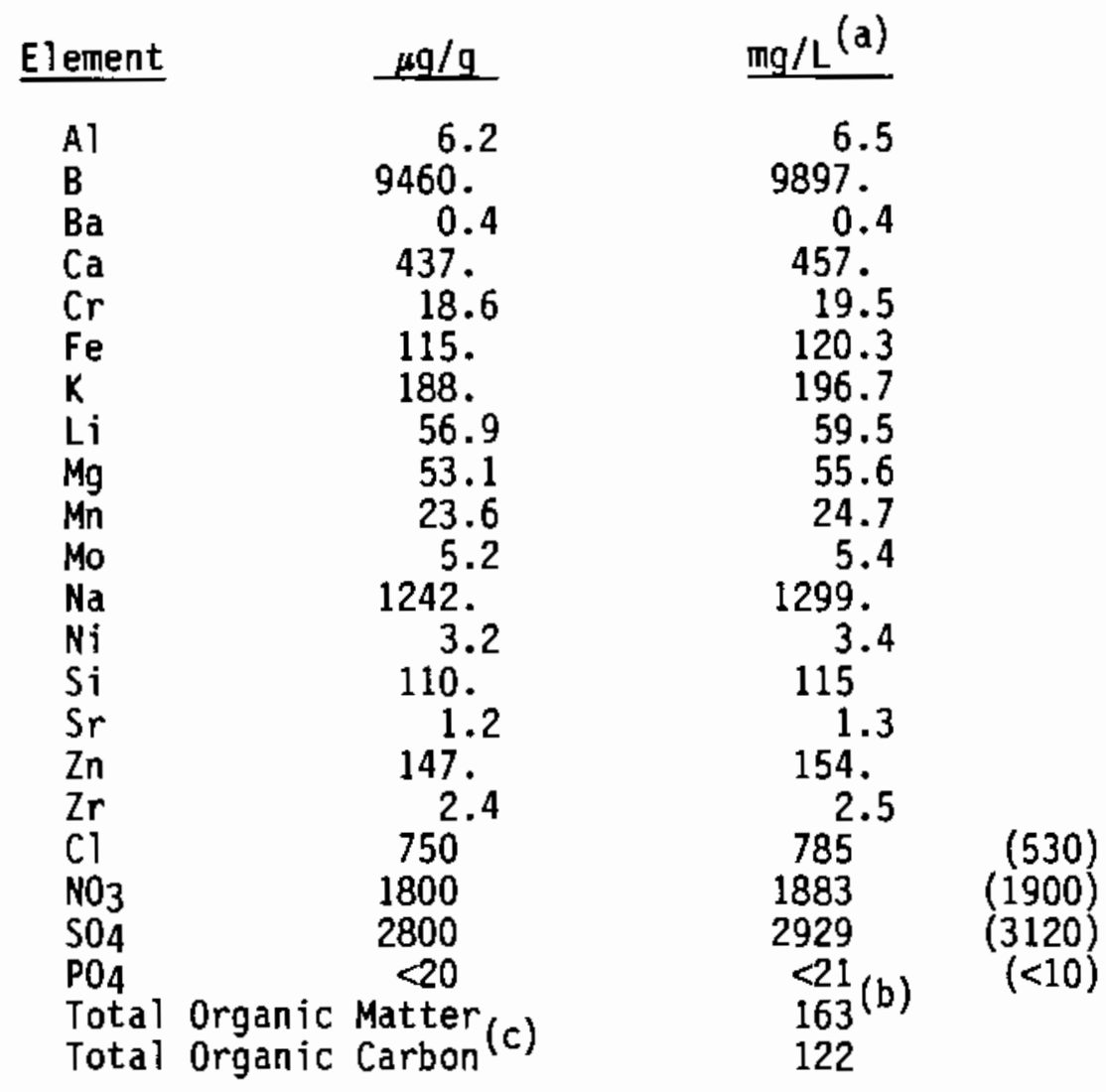

(a) If we assume specific density of the slurry remained constant over the 4-year storage period $(1.046 \mathrm{~g} / \mathrm{mL})$, we can convert to the volume concentration.

(b) Based on liquid fraction $=96 \%$ and solid fraction $=4 \%$ (see Appendix $A$ for details).

(c) Assumes carbon content of organic matter is $75 \%$.

TABLE 3.5. Radionuclide Content of Boric Acid Waste \#2 (decay corrected to $8 / 29 / 84$ )

Radionuclide

${ }^{60} \mathrm{Co}$

${ }^{137} \mathrm{Cs}$

${ }^{134} \mathrm{Cs}$

${ }^{54} \mathrm{Mn}$

$3 \mathrm{H}$ $\mu \mathrm{Ci} / \mathrm{L}$ of Slurry, BNL

$0.78 \neq 0.003$

$0.79 * 0.002$

$0.29 \div 0.003$

$0.13=0.006$ $\mu \mathrm{Ci} / \mathrm{L}$ of Supernatant, PNL
0.75
0.79
0.31
$<$

14.26 
after acquisition on the supernatant only are shown on Table 3.5. The $3 \mathrm{H}$ content of the supernatant was also measured at this time.

The BNL and PNL measurements agree very well suggesting that the precipitates not included in the PNL analysis may contain insignificant amounts of radionuclides (for comparison the precipitates in boric acid waste \#1 contained about $10 \%$ of the total gamana emitters in the slurry). Table 3.6 contains the chemical analyses of the total slurry after storage for 32 months. The waste stream is sodium borate solution with moderate amounts of sulfate, chloride, and aluminum. The sodium concentration is much higher than in boric acid waste \#1 likely because sodium hydroxide was used to neutralize the slurry. The boron concentration of waste \#2 is about $10 \%$ lower than waste $\# 1$, while chloride, nitrate, sulfate, calcium, iron, lithium, magnesium, manganese, and

TABLE 3.6. Chemical Analysis of Boric Acid Waste \#2 Slurry

\begin{tabular}{|c|c|c|}
\hline Element & $\mu g / g$ & $\mathrm{mg} / \mathrm{L}^{(\mathrm{a})}$ \\
\hline Al & 22.4 & 22.7 \\
\hline B & 9080 & 9216.2 \\
\hline $\mathrm{Ba}$ & 0.4 & 0.4 \\
\hline $\mathrm{Ca}$ & 15.8 & 16.0 \\
\hline $\mathrm{Cr}$ & 13.8 & 14.0 \\
\hline $\mathrm{Fe}$ & 10.4 & 10.6 \\
\hline$K$ & 34. & 34.5 \\
\hline $\mathrm{Li}$ & 0.4 & 0.4 \\
\hline $\mathrm{Mg}$ & 4.8 & 4.9 \\
\hline$M n$ & 0.4 & 0.4 \\
\hline Mo & $<0.5$ & $<0.5$ \\
\hline $\mathrm{Na}$ & 5520 . & 5603. \\
\hline $\mathrm{Ni}$ & $<0.5$ & $<0.5$ \\
\hline $\mathrm{Si}$ & 43.2 & 43.8 \\
\hline$S r$ & 0.3 & 0.3 \\
\hline $\mathrm{Ti}$ & 0.14 & 0.14 \\
\hline $2 \pi$ & 3.0 & 3.0 \\
\hline $\mathrm{Zr}$ & 2.6 & 2.6 \\
\hline $\mathrm{Cl}$ & 130. & 132 \\
\hline $\mathrm{NO}_{3}$ & 16. & 16.2 \\
\hline $\mathrm{PO}_{4}$ & $<10$. & $<10$ \\
\hline $\mathrm{SO}_{4}$ & 270 . & 274 \\
\hline
\end{tabular}

(a) Calculations assume density $=1.015 \mathrm{~g} / \mathrm{mL}$. 
zinc are significantly lower. The radionuclide content of boric acid evaporator concentrate $\# 2$ is also much less $(.01$ to $0.1 x)$ than $\# 1$, suggesting perhaps that waste \#1 contains some waste from another plant process. The difference in $\mathrm{pH}$, waste stream $1 \mathrm{pH}=3.2$ and waste stream $\# 2 \mathrm{pH}=8.4$, may explain the much lower $\mathrm{Fe}, \mathrm{Mn}$, and $\mathrm{Zn}$ concentrations as these metals are not very soluble in neutral environments. No organic analyses were completed on this waste stream.

\subsubsection{Sodium Sulfate Evaporator Concentrate}

On September 27, 1983, this sodium sulfate evaporator concentrate was sampled from a commercial boiling water reactor (BWR) site. The waste was a slurry of thick dark brown sludge, crystallized salts and an almost colorless liquid. The slurry has a density of $1.13 \mathrm{~g} / \mathrm{mL}$. The suspended solids content of the slurry was $26.0 \%$ by weight. The supernatant solution had a $\mathrm{pH}$ and Eh value of 11.05 and $290-300 \mathrm{mV}$, respectively.

Aliquots of the slurry were digested with fuming $\mathrm{HNO}_{3}, \mathrm{H}_{2} \mathrm{SO}_{4}$, and $\mathrm{HCl}$. The gamma emitters were determined on the digested solution. The PNL measurements on the supernatant only are presented for comparison in Table 3.7. Both data sets are decay corrected to September 27,1983 . The PNL data suggest that most of the activity is associated with the suspended solids.

A portion of the slurry that had been in storage for about $31 / 2$ years was totally digested and the chemical composition of the waste determined. The results are found in Table 3.8. Details of the organic analysis are found in Appendix A. There is a fairly large organic matter content in this

TABLE 3.7. Radionuclide Content of Evaporator Concentrate (decay corrected to $9 / 23 / 83$ )

\begin{tabular}{cccc} 
Radionuclide & $\mu \mathrm{Ci} / \mathrm{L}$ of Slurry, BNL & $\mu \mathrm{Ci} / \mathrm{L}$ of Supernatant, $\mathrm{PNL}$ \\
\hline${ }^{54} \mathrm{Mn}$ & $39.2 \pm 5.9$ & $<$ \\
${ }^{60} \mathrm{Co}$ & $845 . \pm 130$ & 110 \\
${ }^{134} \mathrm{Cs}$ & $17.4 \pm 2.6$ & $<$ \\
${ }^{137} \mathrm{Cs}$ & $155 \pm 23$ & 22. \\
${ }^{144} \mathrm{Ce}$ & $2.7 \pm 0.6$ & $<$
\end{tabular}


TABLE 3.8. Chemical Composition of Evaporator Concentrate Slurry

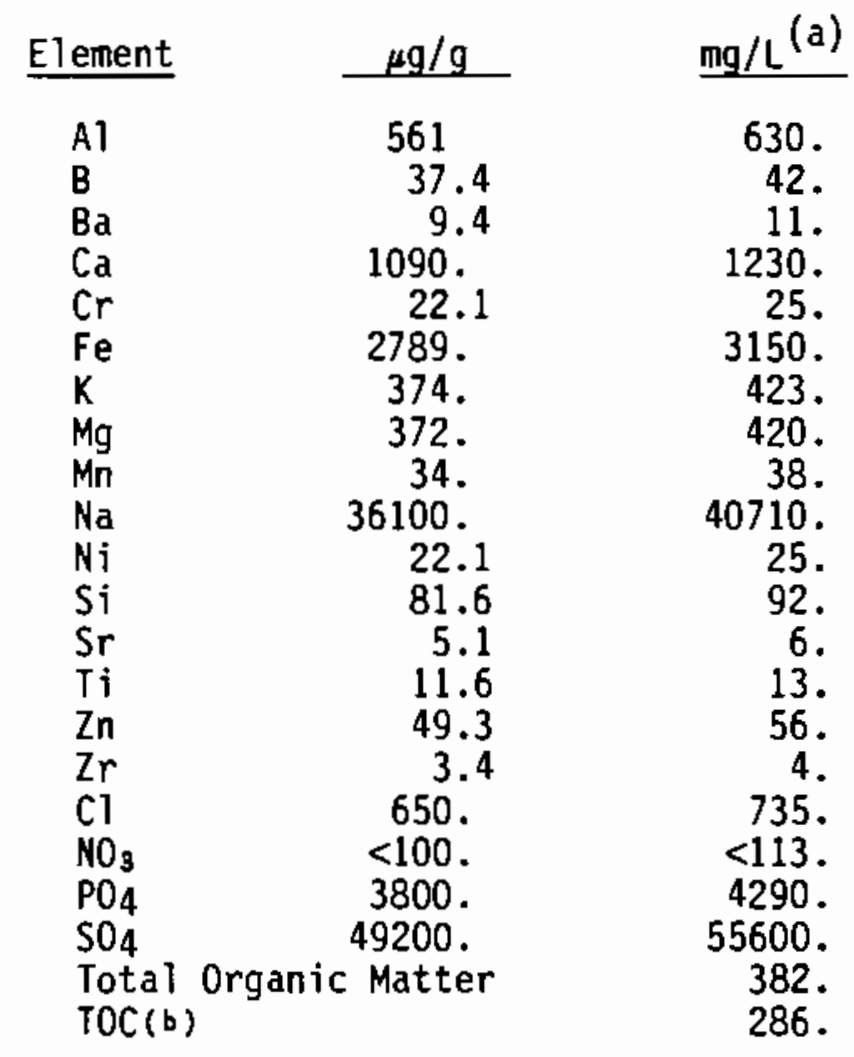

(a) Based on slurry density $=1.13 \mathrm{~g} / \mathrm{mL}$.
(b) Assumes that organic carbon repre-
sents $75 \%$ of organic matter.

waste stream. The total organic carbon value arbitrarily assumes that carbon constitutes $75 \%$ of the organic matter.

The waste strean is predominately a sodium sulfate waste as expected but there is also considerable concentrations of phosphate, iron, calcium, chloride, aluminum, potassium, and magnesium. It is likely that much of the iron, phosphate, aluminum, and magnesium is part of the solid phase in the slurry because these elements are not readily soluble at $\mathrm{pH}=11$.

\subsubsection{Evaporator Concentrate with Ion Exchange Resin}

On September 27, 1983, a second waste stream from the BWR was obtained. The waste stream was the same sodium sulfate waste with spent ion exchange resins added. This waste stream also consisted of a thick dark brown sludge that contained visible resin beads, more crystallized salts than the evaporator 
concentrate, and an almost colorless liquid. The density of this slurry was 1.27, $\mathrm{g} / \mathrm{mL}$ and the suspended solids content was $38.4 \%$. The $\mathrm{pH}$ and Eh values of the supernatant were $10.36 \pm 0.02$ and $260 \mathrm{mV}$, respectively. Aliquots were totally digested in sequential treatments with $\mathrm{HNO}_{3}, \mathrm{H}_{2} \mathrm{SO}_{4}$, and $\mathrm{H}_{2} \mathrm{O}_{2}, \mathrm{HF}$, and $\mathrm{H}_{2} \mathrm{SO}_{4}-\mathrm{HCl}$. The gamma nuclide inventory decay corrected to September 27, 1983, are shown in Table 3.9. Measurements on the supernatant made by PNL approximately 3.5 years after acquisition are also shown in Table 3.9.

Again it appears that the bulk (approximately 90\%) of the radionuclide content is present in the suspended solids. This waste stream contains about twice as much radioactivity as the evaporator concentrate waste suggesting that the resin beads are quite radioactive.

An aliquot of the slurry was totally digested in concentrated acids and the chemical composition determined. The results are shown in Table 3.10. A complete anatysis of the waste stream for organic matter was also performed. Details are shown in Appendix A. The total organic carbon number found in Table 3.10 is an estimate assuming that the average organic carbon content of the organic matter is arbitrarily $75 \%$ of the total molecular weight.

\subsection{CALCULATION OF RADIONUCLIDE INVENTORY IN EACH DRUM}

The volume of each waste stream that was solidified in each 55-gallon drum was estimated by process flow sheet information in most cases. For many of the solidified waste drums a second independent method based on nondestructive ganma logging of the entire drum was performed. For the bitumen waste form actual dissolution of a representative solid sample was performed. In general, the accuracy of the drum inventories varies with solidification

IABLE 3.9. Radionuclide Content of Evaporator Concentrate Plus Ion Exchange Resin (decay corrected to 9/27/83)

\begin{tabular}{cccc} 
Radionuclide & $\mu C i / L$ of Slurry, BNL & & $E C i / L$ of Supernatant, PNL \\
\hline${ }^{54} \mathrm{Mn}$ & 87.2 & $\neq 13.1$ & $<$ \\
${ }^{60} \mathrm{Co}$ & 1580. & $\neq 240$ & 150. \\
${ }^{134} \mathrm{Cs}$ & 36.0 & $\neq 5.4$ & $<$ \\
${ }^{137} \mathrm{Cs}$ & 234. & $\neq 35$ & 25.8 \\
${ }^{144} \mathrm{Ce}$ & $4.0 \neq 1.3$ & $\neq$
\end{tabular}


IABLE 3.10. Chemical Composition of Evaporator Concentrate Plus Ion Exchange Resin

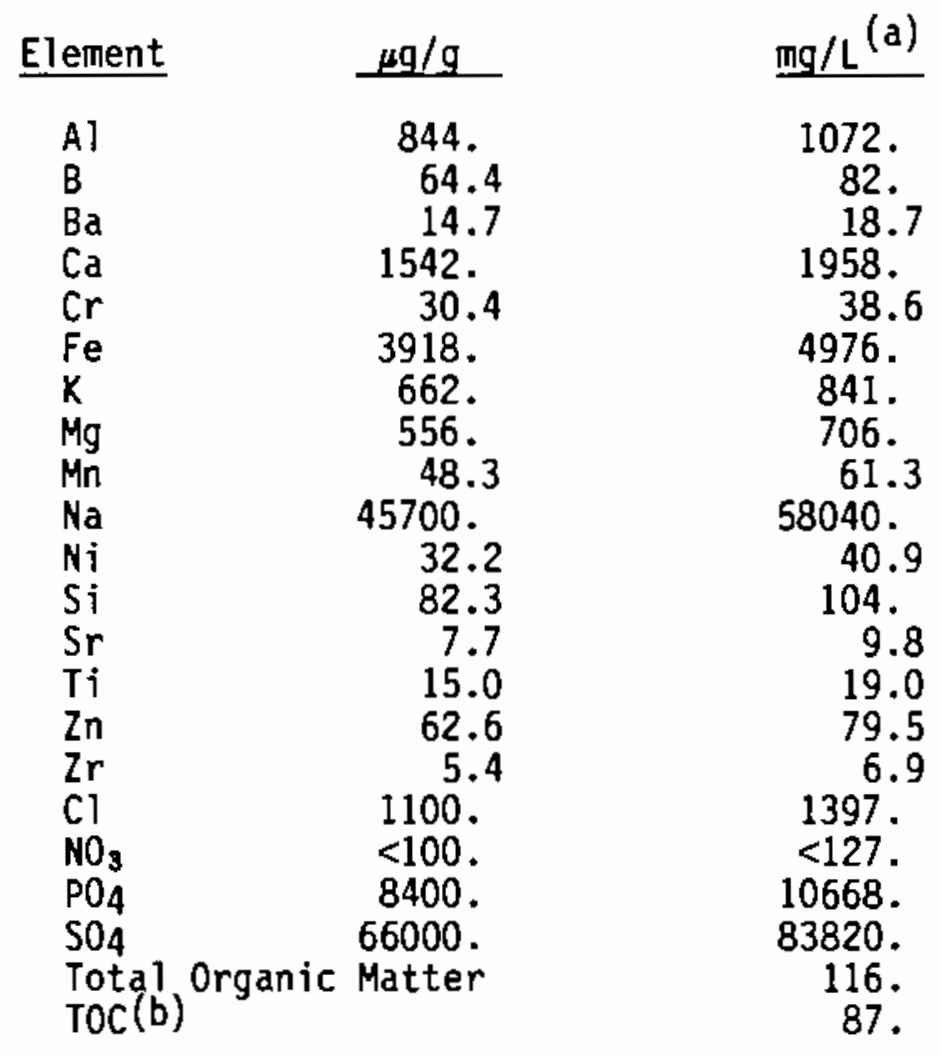

(a) Conversion based on density $=1.27 \mathrm{~g} / \mathrm{cm}^{3}$.
(b) Assumes $O C=75 \%$ of total organic matter.

process. When properly calibrated, the nondestructive gamma logging technique is more accurate than process flow sheet or production line monitoring. The nondestructive technique is also less tedious than product dissolution and measurement. The details for the nondestructive counting can be found in Brodzinski (1986) and Brodzinski et al. (1987). Briefly, the steel drum containing the waste form is placed on a rotating table top and counted with a high-resolution germanium diode, well-logging, ganma-ray spectrometer fit with a variable width tungsten horizontal slit collimator. The waste form is slowly rotated on the table top as the collimator is fixed at each height. Counts around the perimeter of the cylinder at each height are recorded and compared with known standards of gamana emitters in cement or vinyl-ester styrene polymer. 
A physical description of the drums is found in Table 3.11. The total inventories for the barrels as calculated by BNL personnel are compared to nondestructive counting of waste-forms performed by PNL personnel in Table 3.12. Where available comments on the accuracy are provided. The activities are decay corrected to the date of fabrication.

\subsubsection{Drums $4-1 B$ and $4-2 B$}

Drums $4-1 B$ and $4-2 B$ contained boric acid waste stream \#1 solidified in masonry cement, which consists of $50 \%$ Portland Type I cement and $50 \% 1$ ime. The solidification was performed using an Atcor Engineered Systems, Inc. (Farmington, Connecticut) in-line mixer/feeder. The process consisted of first placing a thin base of dry binder into the drum, next some liquid waste was pumped into the drum; then both binder and waste were added at a preset feed rate of $1: 1$ by volume. The drums were filled only two-thirds ful1. Drum $4-1 \mathrm{~B}$ weighed $283 \mathrm{~kg}(625 \mathrm{lb})$ and had a dose rate of $40 \mathrm{mR} / \mathrm{hr}$ at contact. Drum $4-2 B$ weighed $272 \mathrm{~kg}(600 \mathrm{lb})$ and had a higher dose rate of $45 \mathrm{mR} / \mathrm{hr}$. It would appear from the dose rates and weights that drum $4-2 B$ should have a larger weight or smaller dose rate all other things being constant. The system operators were quite confident $( \pm 10 \%)$ that each drum received about $76 \mathrm{~L}$ of liquid waste. The BNL personnel calculated the drum inventories based on drum 4-1B containing exactly $76 \mathrm{~L}$ of waste with the slurry activities reported in Table 3.2. Drum $4-2 B$ was assumed to contain slightly less, based on the lower weight, even though drum $4-2 B$ showed more dose. Table 3.12 compares the direct counting values versus the estimates based on liquid waste volume. The direct counting of drum $4-2 B$ suggests that it contains more inventory than drum 4-1B, which agrees with the dose measurements. From the directly measured inventories, the volume of liquid slurry found in each drum can be calculated from Table 3.2. The average liters of waste calculate to be $74 \pm 6$ and $84 \pm 8 \mathrm{~L}$, respectively, for drums $4-1 B$ and $4-2 B$. These values compare favorably with the plant operators estimate that each drum contained $76 \mathrm{~L}$. Because the direct counting values agree closer with the observed dose rates, PNL believes these values are most accurate. The tritium inventories were calculated assuming 74 and $84 L$ of waste in drums $4-1 B$ and $4-2 B$, respectively. 
IABLE 3.11. Description of Drums

\begin{tabular}{|c|c|c|c|c|}
\hline Drum \# & Waste Stream & Binder & Weight, $\mathrm{kg}$ & Dose, $\mathrm{mR} / \mathrm{hr}$ at contact \\
\hline $4-1 B$ & Boric acid $\# 1$ & Masonry cement & 283 & 40 \\
\hline $4-2 B$ & Boric acid \#1 & Masonry cement & 272 & 45 \\
\hline Drum 1 & Boric acid $\sharp 2$ & Bitumen & 160 & $n a^{(a)}$ \\
\hline Drum 2 & Boric acid $\# 2$ & Bitumen & 170 & na \\
\hline $1-1 B$ & Evaporator conc. & Portland III cement & 345 & 500 \\
\hline $1-2 B$ & Evaporator conc. & Portland III cement & 346 & 500 \\
\hline $2-1 B$ & Evap. + IEX resin & Portland III cement & 342 & 600 \\
\hline $2-2 B$ & Evap. + IEX resin & Portland III cement & 342 & 800 \\
\hline $2-3 B$ & Evap. + IEX resin & Portland III cement & 351 & 1200 \\
\hline $7-2 B$ & Evap. + IEX resin & Polymer & 170 & 700 \\
\hline $7-3 B$ & Evap. + IEX resin & Polymer & 189 & 900 \\
\hline
\end{tabular}

(a) Not available. 
IABLE 3.12. Decay-Corrected Source Inventories of Radionuclides in Drums, mCi

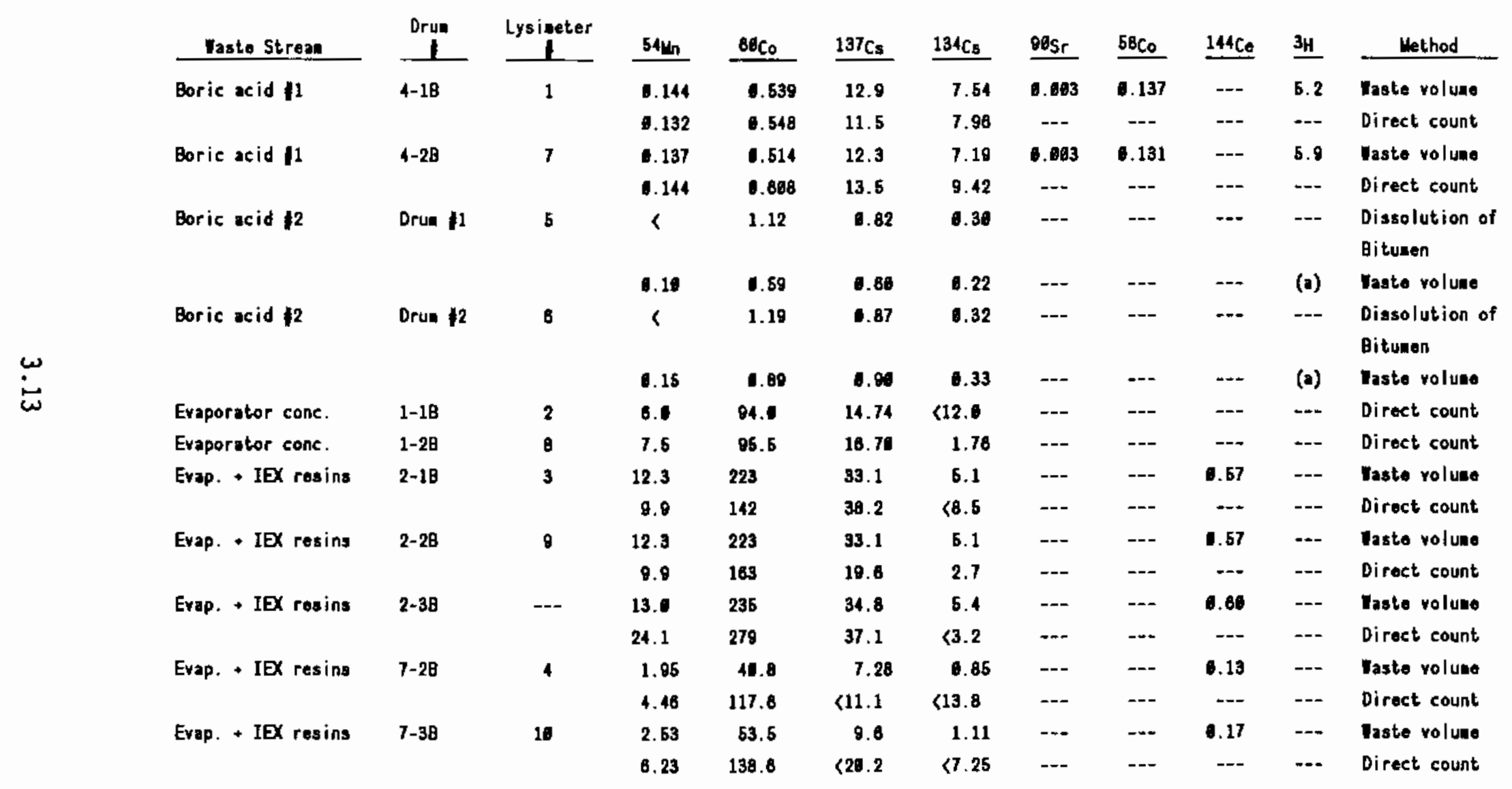

(a) Although waste strean has measurable 3 H, it is assuned that it evaporates during bitunen processing. 


\section{2 .2 Drums \#1 and \#2}

Two drums that contain boric acid waste stream $\# 2$ solidified in bitumen were generated with a Waste Chem extruder. Liquid waste and molten bitumen are pumped into a screw extruder where they are thoroughly mixed and heated to temperatures between 132 and $188^{\circ} \mathrm{C}$. The mixing process continues for an adequate time for $>99 \%$ water evaporation. The final product, salts bound in bitumen, is extruded directly into the drums. According to plant personnel, drum \#1 contained the salts from $757 \mathrm{~L}$ of waste bound in $122 \mathrm{~L}$ of bitumen. The filling process took 10 hours, and the drum weighed $160 \mathrm{~kg}$ (352 lb). Drum $\$ 2$ contained the salts from $1135 \mathrm{~L}$ of waste bound in $136 \mathrm{~L}$ of bitumen. The filling process took 8.5 hours and the drum weighed $170 \mathrm{~kg}(374 \mathrm{lb})$.

The total radionuclide inventory of the bitumen drums was calculated two ways. The first attempt relied on dissolution (using $100 \mathrm{~mL}$ xylene) of numerous 1-g samples of bitumen taken from several small right cylinders produced during the filling of the drums. The results suggest that the radionuclide content is not homogeneously distributed throughout the bitumen. The BNL staff speculated that radionuclide-bearing salts may settle during bitumen cooling. The second method of calculating drum inventories was to multiply the observed radionuclide concentrations in the liquid waste stream by the estimated volumes of waste solidified in each drum. The BNL staff prefer the latter approach. No nondestructive barrel counting was performed on the bitumen drums because they were received months after the counting and emplacement in the lysimeters of the other eight waste forms. Following BNL's judgment, PNL used the inventories based on the liquid waste stream concentrations. It is assumed that $3 \mathrm{H}$ present in the liquid waste evaporates and is not present in the final solid waste drums.

\subsubsection{Drums $1-1 \mathrm{~B}$ and $1-2 \mathrm{~B}$}

The waste stream solidified in drums $1-1 B$ and $1-2 B$ was sodium sulfate evaporator concentrate. This liquid waste was solidified with Portland Type III cement using Stock Equipment Company (Cleveland, Ohio) machinery. First the cement is added to the drum and then $55 \%$ of the predetermined volume of liquid waste is added. The drum is closed and tumbled end over end for 6 minutes. The drum is reopened and the remaining $45 \%$ waste volume is added and the drum tumbled end over end for 5 minutes. The weight and dose levels 
for the two cement drums are shown in Table 3.11. No inventory estimates were supplied as the volume of waste was not specified. The only estimate for the total inventories of radionuclides in these drums is the nondestructive barrel counting. The direct counts suggest that the drums contain between 120 and $130 \mathrm{~L}$ of liquid waste, which compares closely with the 141-L estimate for the solidified evaporator concentrate plus ion exchange resin to be discussed next.

\subsubsection{Drums 2-1B, 2-2B, 2-3B}

The waste stream solidified in drums 2-1B, 2-2B, and 2-3B contained the same sodium sulfate evaporator concentrate found in drums 1-1B and 1-2B. However, series $\# 2$ drums also contained spent ion exchange resin in addition to the evaporator concentrate. The plant operators estimated that $141 \mathrm{~L}$ of liquid waste slurry was mixed into the drums. For drum 2-3B the liquid volume was estimated to be $149 \mathrm{~L}$. BNL thus estimated the total drum inventories based on the product of the slurry concentrations and this volume. The wide range in measured dose rates, 600,800 , and $1200 \mathrm{mR} / \mathrm{hr}$ respectively, suggests that the volumes of waste in each drum is not so uniform or that the distribution of radionuclides within the drums is not uniform. The direct count seco data show the same progression as the dose rate data. For this reason we have elected to use the direct barrel counting inventory in further radionuclide calculations. Drum $2-18$ direct counting suggests that the drum contains $122 \pm 40 \mathrm{~L}$ of slurry waste and drum 2-2B direct counting data suggests that the drum contains $94 \neq 18 \mathrm{~L}$ of waste. These values are not as close to the $141 \mathrm{~L}$ suggested by plant operators as agreement for some of the other waste forms. Orum 2-3B was an extra and is not emplaced in the field lysimeter.

\subsubsection{Drums $7-2 \mathrm{~B}$ and $7-3 \mathrm{~B}$}

Drums $7-2 B$ and 7-3B of evaporator concentrate plus ion exchange resins were solidified into vinyl-ester styrene using a mobile system of Dow Chemical Nuclear and Solidification Services (Midland, Michigan). Briefly, the procedure is to place a premeasured quantity of vinyl-ester styrene in a 55-gallon drum. The aqueous waste and promoter catalyst was mixed under high shear mixing. One drum of this waste type and two drums of evaporator concentrate did not solidify. To effectively set up, different ratios of evaporator concentrate and ion exchange resins were used than the ratios emplaced in cement. The total inventory of each polymer drum was estimated by BNL 
from the volume of evaporator concentrate and ion exchange resin added as given by process information. The BNL assumptions used to generate inventory calculations are not clear, but available waste volume (BNL) calculations and direct measurement (PNL) inventories are found in Tables 3.11 and 3.12, respectively. The direct count data were chosen for future calculations.

PNL's best estimates of the volume of waste in each drum is shown in Table 3.13. The preferred radionuclide inventories for each waste drum and the lysimeter designations are shown in Table 3.14 along with selected chemical inventories.

\subsection{CALCULATION OF CHEMICAL INVENTORY IN EACH ORUM}

As mentioned, approximately 3.5 years after acquisition the slurry waste streams were analyzed for total chemical composition. The total waste stream chemical inventory was calculated from these data and estimates of the volume of slurry in each drum. The inventories represent only mass originating in the liquid slurries; in other words, the chemical composition of the binding agents (cement, polymer, and bitumen) is ignored. The inventory data for selected chemicals (those observed to leach and reach the lysimeter drains in concentrations above ambient background) are shown in Table 3.14.

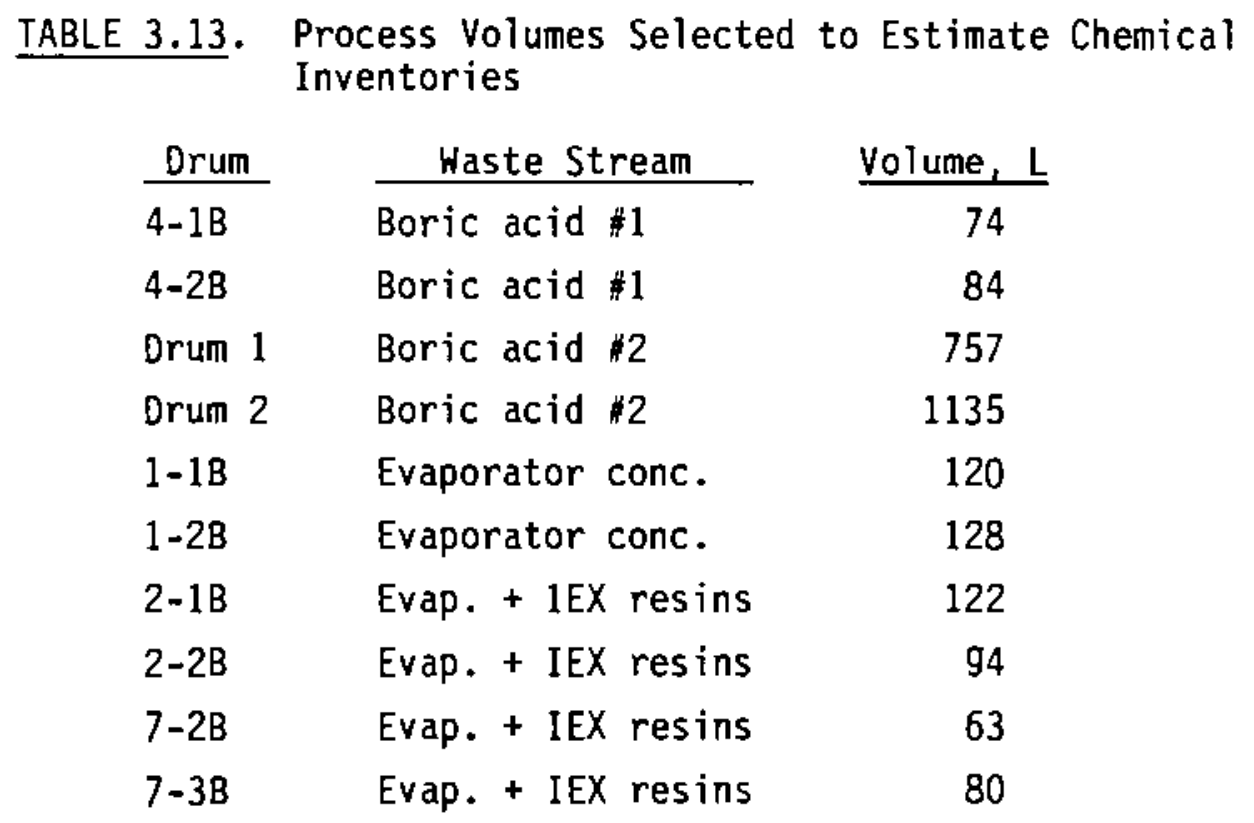


IABLE 3.14. Estimated Chemical and Preferred Radionuclide Inventory in Waste Forms

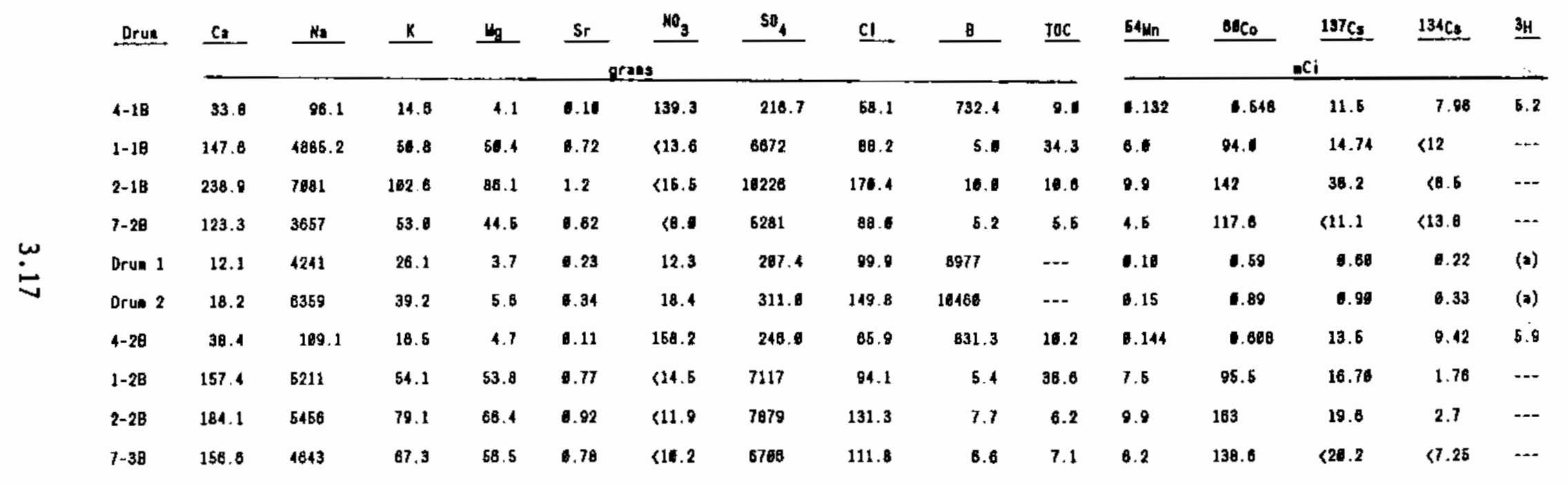

(a) During bitunen processing ${ }^{3} \mathrm{H}$ should evaporate and leave wasto forn. 
The chosen volumes are shown in Table 3.13. These values when multiplied by the concentrations shown in Tables $3.3,3.5,3.7$, and 3.9 yield the estimates found in Table 3.14. For the drums of Dow polymer we had to assume that the waste slurry was identical to that used to create the cement waste forms even though it is known that more resin beads and less evaporator concentrate was used to get the polymer to set up. No samples or data on the actual waste mixture placed in polymer are available.

The total inventories of chemicals and radionuclides in each drum can be compared with the mass of each constituent collected in the lysimeter drainage to determine the relative migration rate of constituents. For the chemicals, the comparison is confounded by the potential for the solid binder and sediment to add leachable mass to the drainage mass. Thus, for most of the chemicals, the comparison should be viewed qualitatively. Further, the chemical composition of drainage leachates is determined only every 3 months while drainage water is collected every 2 weeks. Thus an extrapolation scheme was devised to approximate masses of each constituent that has drained. The radionuclide drainage data also suffers from this need to extrapolate many of the early samples. Since June 6,1986 , the radionuclide contents of each drainage sample (taken every 14 days) has been measured to facilitate accurate mass balance calculations. Total chemistry has not been performed on every sample because of budget constraints. The interpolation scheme is described in Appendix D. 


\subsection{LYSIMETER HYDROLOGY}

The release of contaminants from the solid waste forms and subsequent transport through the soil depend on the hydrologic environment of the lysimeters as well as on the chemistry of the waste. The water content of the soil can affect solute diffusion coefficients and, to some degree, solubility processes. The flux or rate of water flow through the soil controls the convective and dispersive transport of solutes once they leave the waste form and enter the soil system. Soil-water contents and fluxes are determined by the climatic conditions such as precipitation, temperature, and solar radiation, as well as the soil hydraulic properties such as hydraulic conductivity and water holding capacity. In this section, the most important hydraulic properties of the lysimeter soil material are discussed, and the lysimeter water balance is described in terms of the storage of water in the soil profile and the drainage of water out the lysimeter. Finally, the effect of these water balance parameters on relevant transport parameters is summarized.

\subsection{SOIL HYDRAULIC PROPERTIES}

The soil material used to fill the lysimeters is from flood deposits found throughout the Hanford Site. These sediments consist of coarse sands and gravels, with minimal silt and clay fractions. The material used to fill the lysimeters was screened to remove the gravel and the remaining material consists of $92 \%$ sand, $6 \%$ silt, and $2 \%$ clay (Walter, Graham and Gee 1984).

The coarse nature of the sandy material is illustrated by the water retention curve and hydraulic conductivity function shown in Figure 4.1. Measurements of water retention and saturated hydraulic conductivity were made on samples from each lysimeter individually to check for variability among lysimeters. These data are reported in Walter, Graham and Gee (1984). No obvious trend in variability was discovered, and the data shown in Figure 4.1 are average values. The unsaturated hydraulic conductivity data shown in Figure 4.1 are calculated from field measurements of soil water content and drainage rates. The composite data represent at least two data points from each of the 10 lysimeters. Four observations can be made from the data in Figure 4.1 that are all consistent with the known coarse nature of the lysimeter fill 

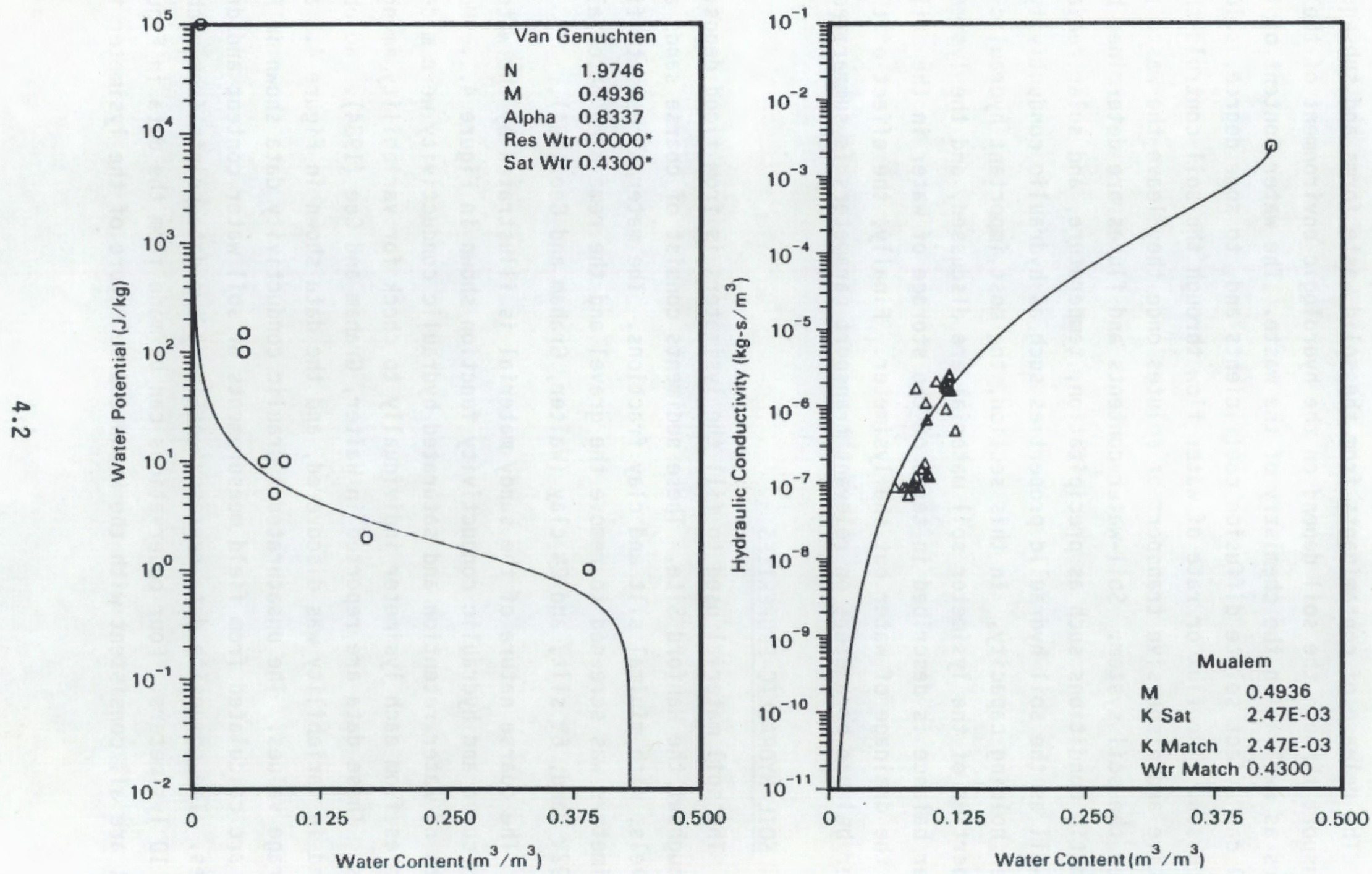

FIGURE 4.1. Water Retention and Hydraulic Conductivity Curve for Lysimeter Soil 
material: 1) the saturated hydraulic conductivity is relatively high; 2) the air entry potential is $\sim-1 \mathrm{~J} / \mathrm{kg}(-10 \mathrm{~cm}$ of water); 3$)$ the water content $(\sim 8.0 \%)$ at a water potential of only $-10 \mathrm{~J} / \mathrm{kg}(-100 \mathrm{~cm}$ of water $)$ is relatively low; and 4) the hydraulic conductivity drops four orders of magnitude in the 0 to $-10 \mathrm{~J} / \mathrm{kg}$ range.

The smooth curves in Figure 4.1 come from an analysis described by van Genuchten (1978). The equation describing the water retention curve is of the form:

$$
\theta=\theta_{r}+\left(\theta_{s}-\theta_{r}\right)\left[\frac{1}{1+(a \phi)^{n}}\right]^{m}
$$

where $\theta=$ volumetric water content, $\mathrm{m}^{3} / \mathrm{m}^{3}$

$$
\begin{aligned}
\theta_{S} & =\text { SAT WTR }=\text { saturated water content, } \mathrm{m}^{3} / \mathrm{m}^{3} \\
\theta_{r} & =\text { RES } \text { WTR }=\text { residual water content, } \mathrm{m}^{3} / \mathrm{m}^{3} \\
& =\text { soil water potential, } \mathrm{J} / \mathrm{kg} \\
\alpha & =\text { ALPHA }=\text { fitting parameter } \\
n & =N=\text { fitting parameter } \\
M & =1-1 / \mathrm{n} .
\end{aligned}
$$

The saturated water content was calculated from the bulk density of the samples, and the residual water content was taken as zero. The parameters ALPHA and N were curve fit from the data according to the procedure described by van Genuchten (1978).

The hydraulic conductivity curve shown in Figure 4.1 is predicted from the measured desorption curve following the theory of Mualem (1976). The theory requires one matching point. In Figure 4.1 the curve was matched to the measured saturated hydraulic conductivity as reported by Walter, Graham and Gee (1984). The equation is of the form:

$$
K(\theta)=K_{S} \theta^{1 / 2}\left[1-\left(1-\theta^{1 / m}\right)^{m}\right]^{2}
$$

where $K_{S}$ is K_SAT is saturated hydraulic conductivity and $\theta=\frac{\left(\theta-\theta_{r}\right)}{\left(\theta_{S}-\theta_{r}\right)}$. 


\subsection{LYSIMETER WATER BALANCE}

The soil physical properties measured for the lysimeter soil (i.e., particle size distribution, water retention, and saturated hydraulic conductivity) show no systematic difference in soil properties among lysimeters. Therefore, the water balance of each lysimeter should be similar. A preliminary analysis of the data has confirmed that the water balance of the lysimeters are similar. Water balance data are summarized here; however, complete water content data are listed in Appendix B, and complete drainage data are given in Appendix D.

Figure 4.2 shows the initial water contents of lysimeters $1,4,7$, and 9. The water contents are quite similar both with depth and among lysimeters with the exception of the slightly dryer surface soil of lysimeter 4 . The wetter surface soil found in other lysimeters is due to rain events during and immediately after filling of the lysimeters.

The seasonal pattern of water storage in lysimeters 1,4 , and 7 is shown in Figure 4.3. The small differences in initial storage values are because of the differences in initial water contents already mentioned. These differences quickly disappear as the winter precipitation wets the soil and soil water storage increases. By late winter, the amount of water stored in all three lysimeters is essentially equal and remains so for most of the next 2 years.

Figure 4.3 also shows the distinctive seasonal pattern in water storage observed in all lysimeters. The peak soil-water storage occurs during the late winter months, which corresponds with the season of peak precipitation at the Hanford Site. Additionally, most of this winter precipitation occurs as snow. Both the winter of 1984-85 and the winter of 1985-86 were extremely cold, preventing significant snow melt during the winter. In both years, most of the winter snowpack melted rapidly in February and produced the sharp peaks in seasonal storage.

The high water storage in February is followed by a steady decline throughout the spring and summer, with minimum storage occurring in early fall just prior to the onset of the next winter's precipitation. Note again the similarity in water storage among the three lysimeters shown in Figure 4.3, 


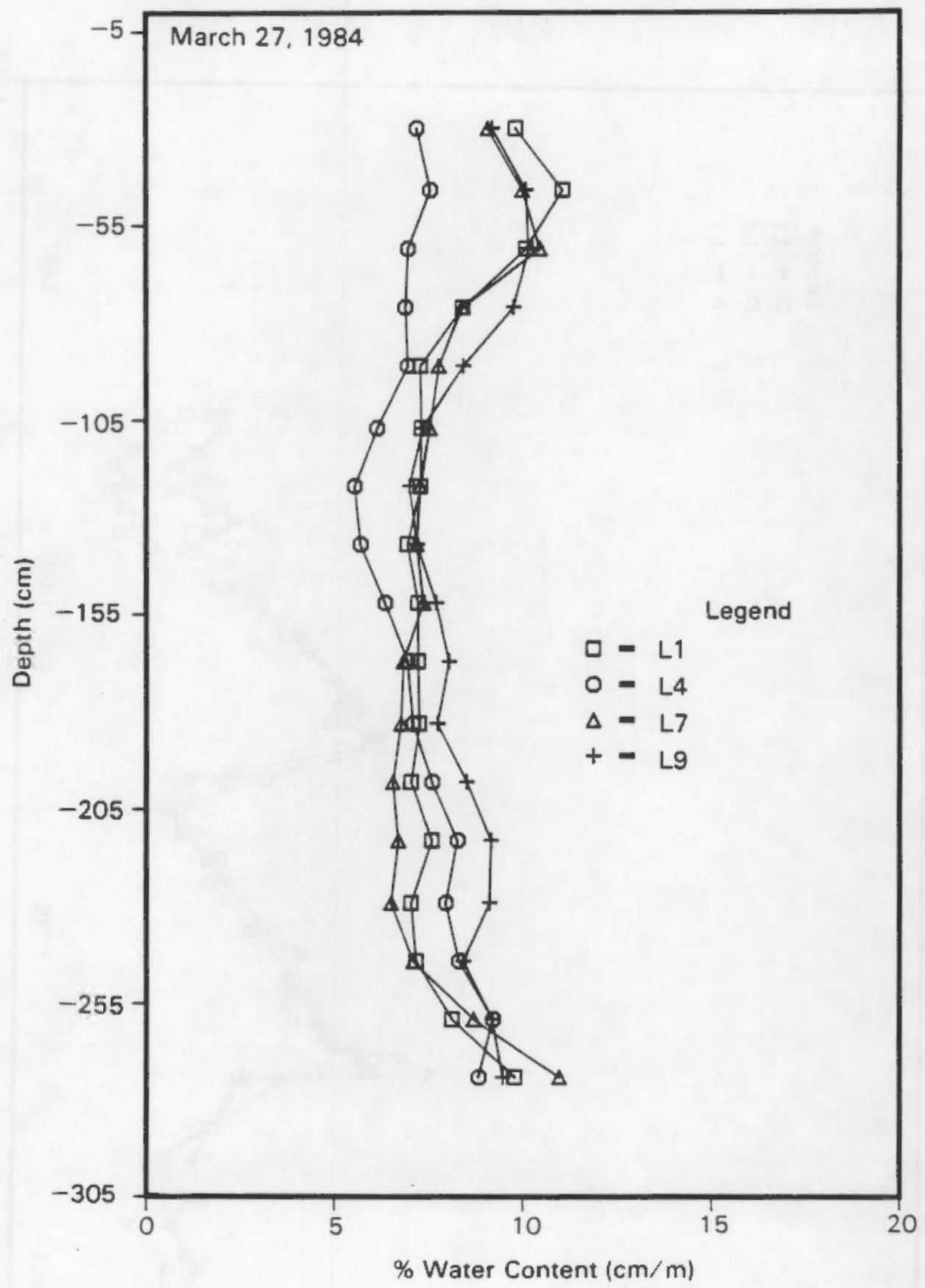

FIGURE 4.2. Initial Water Content Profile for Lysimeters 1, 4,7 , and 9 


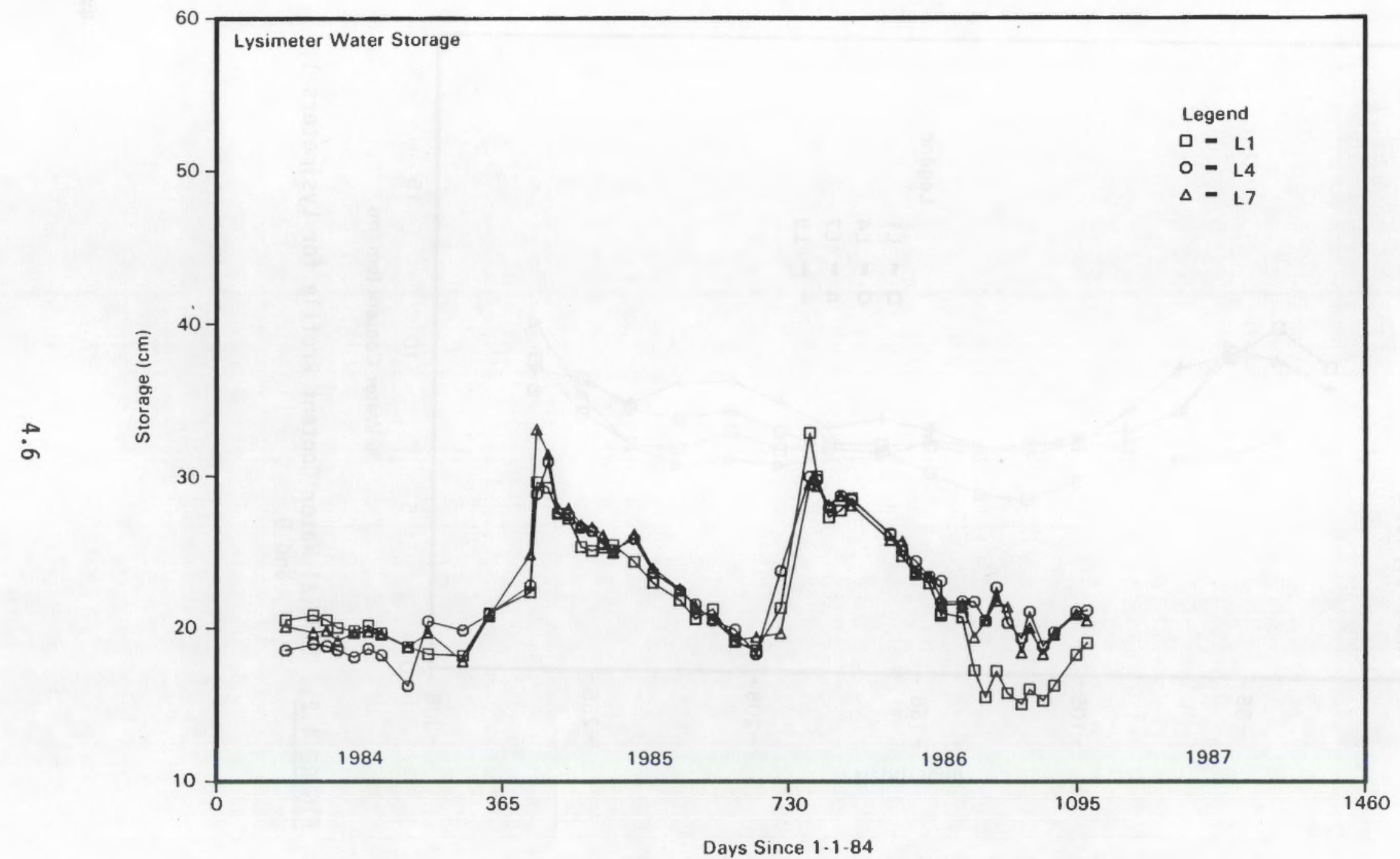

FIGURE 4.3. Profile Water Storage for Lysimeters 1, 4, and 7 
particularly during 1985 and the winter of 1986. Lysimeter 1 shows less storage during the summer of 1986 , but not to any large degree.

The drainage pattern for lysimeters 1, 4, and 7 is shown in Figure 4.4. As expected, the patterns are somewhat the inverse of the storage patterns shown in Figure 4.3. As the water storage is declining from February to october each year, the cumulative drainage is increasing. The drainage rate, however, decreases as the soil profile dries.

The similarity in the water balance behavior of lysimeters 1, 4, and 7 also holds for lysimeters 2 and 3 . This similarity was expected because of the similarity in soil properties discussed above. However, there are factors other than soil type that can influence the water balance of a soil profile. There were two anomalies that made the water balance of lysimeters 5,6 , and 8-10 temporarily different from the other 5. The water balance of lysimeters 5 and 6 was significantly affected by low initial water contents. As stated above, lysimeters 5 and 6 were filled in September 1984, 6 months later than the others. As a result, the soil used to fill the top $2 \mathrm{~m}$ of lysimeters 5 and 6 had been dried to a relatively low water content during the summer. Figure 4.5 shows that in September 1984 the volumetric water content in the top $1.5 \mathrm{~m}$ of lysimeters 5 and 6 was approximately $2.5 \%$, in contrast to the $7 \%$ water content of lysimeters 1 and 9 . The higher water content illustrated by lysimeters 1 and $g$ is also representative of the other six lysimeters that had been filled in March.

The effect of these dry initial conditions was to retard the wetting of the soil profile in lysimeters 5 and 6 during the winter of 1984-85. Figure 4.6 shows how the storage of water in lysimeters 5 and 6 lagged behind lysimeter 1. Similar comparisons can be made with other lysimeters as well. By the end of the first wetting and drying cycle (September 1985), the effect of the initially dry conditions was effectively removed. Lysimeter 6 still lags behind during the second cycle (1985-86), but not by as much as in 1984-85. All three lysimeters $(1,5$, and 6$)$ seemed to respond similarly during the winter of 1986-87.

The dry initial conditions also affected drainage from lysimeters 5 and 6. Figure 4.7 shows how the initial drainage of water from lysimeters 5 and 6 was delayed by almost 1 year. This delay in initiation of drainage was 


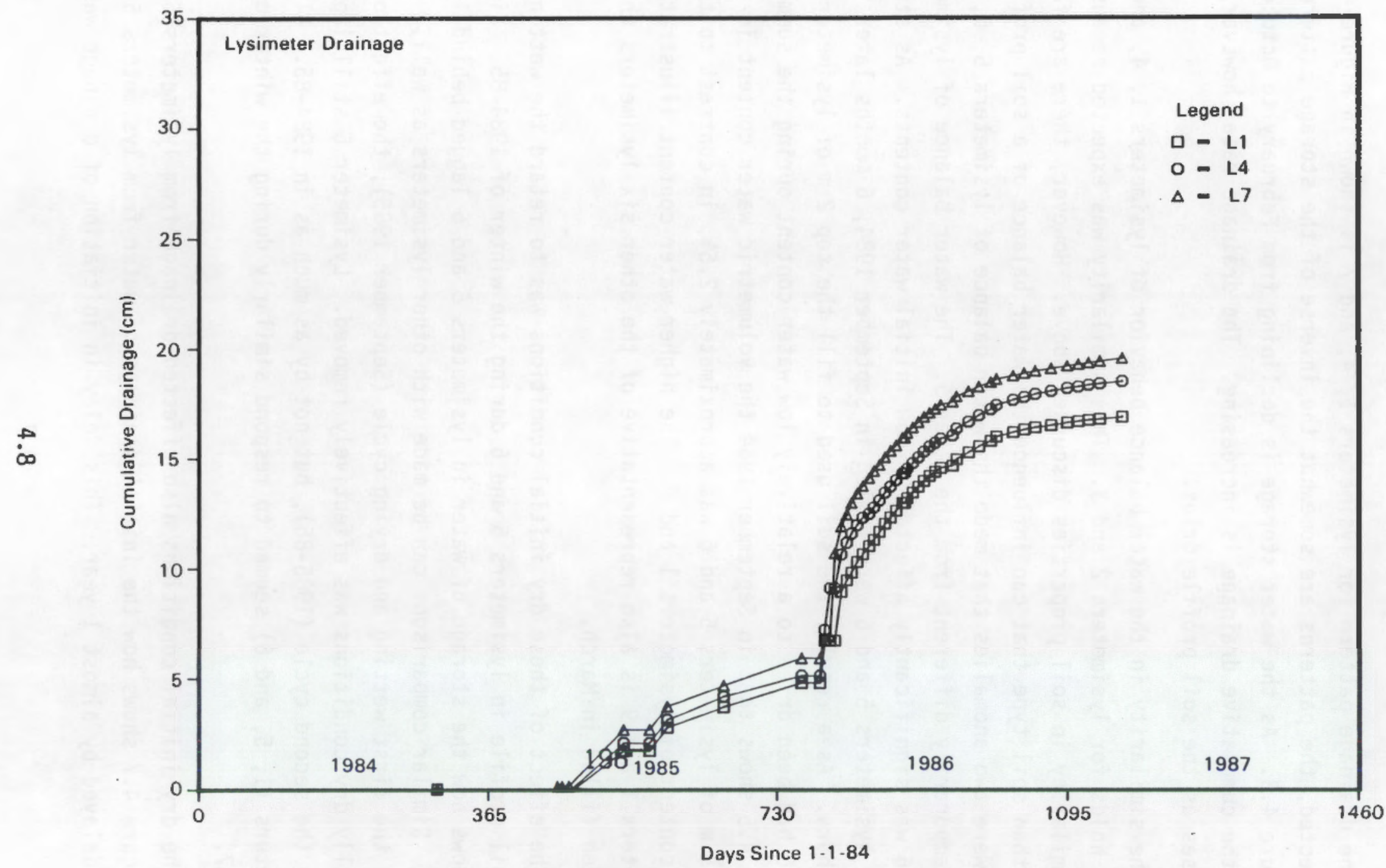

FIGURE 4.4. Cumulative Drainage for Lysimeters 1, 4, and 7 


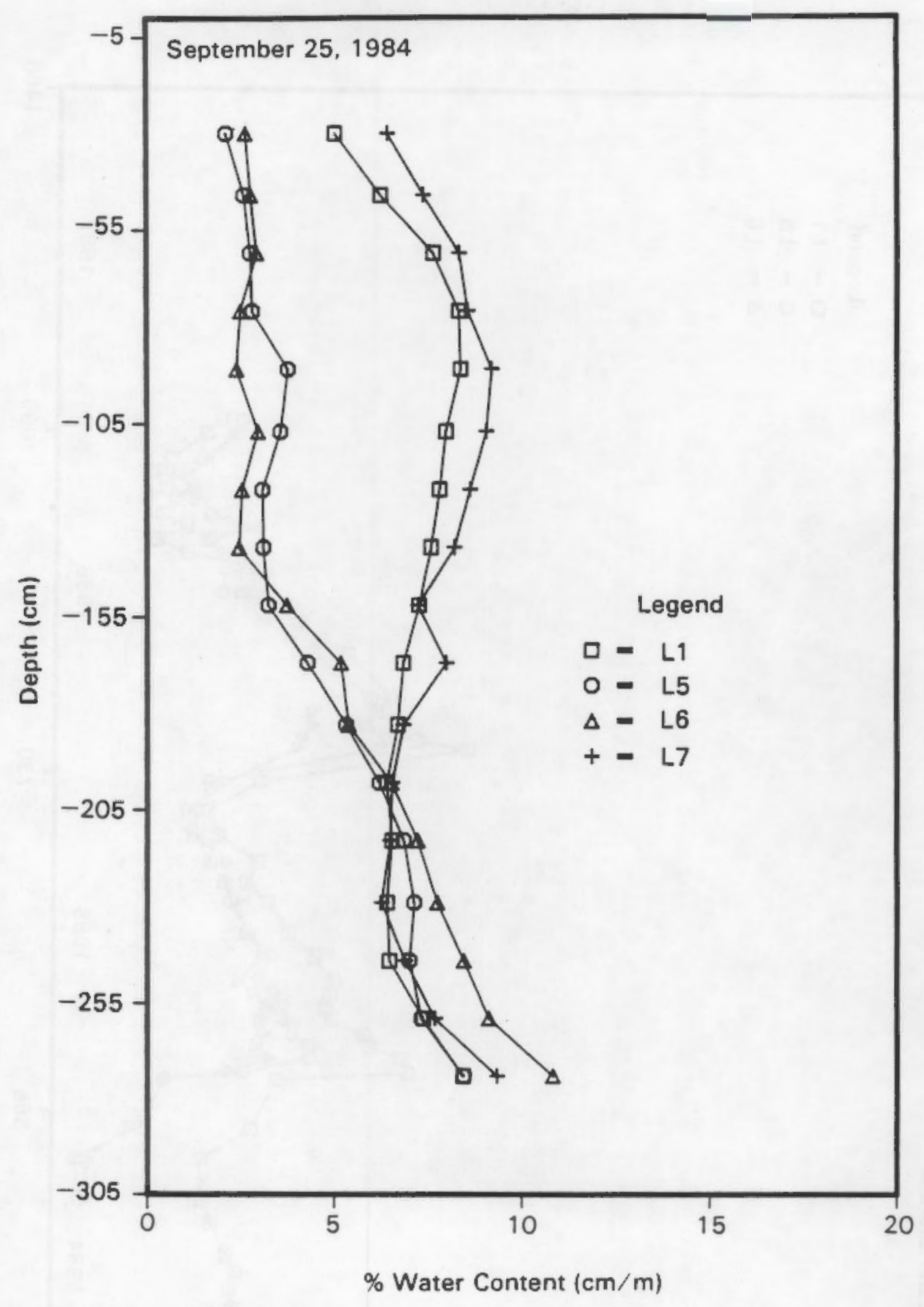

FIGURE 4.5. Water Content Profile for Lysimeters 1, 5, 6 , and 7 for $9 / 25 / 84$ 


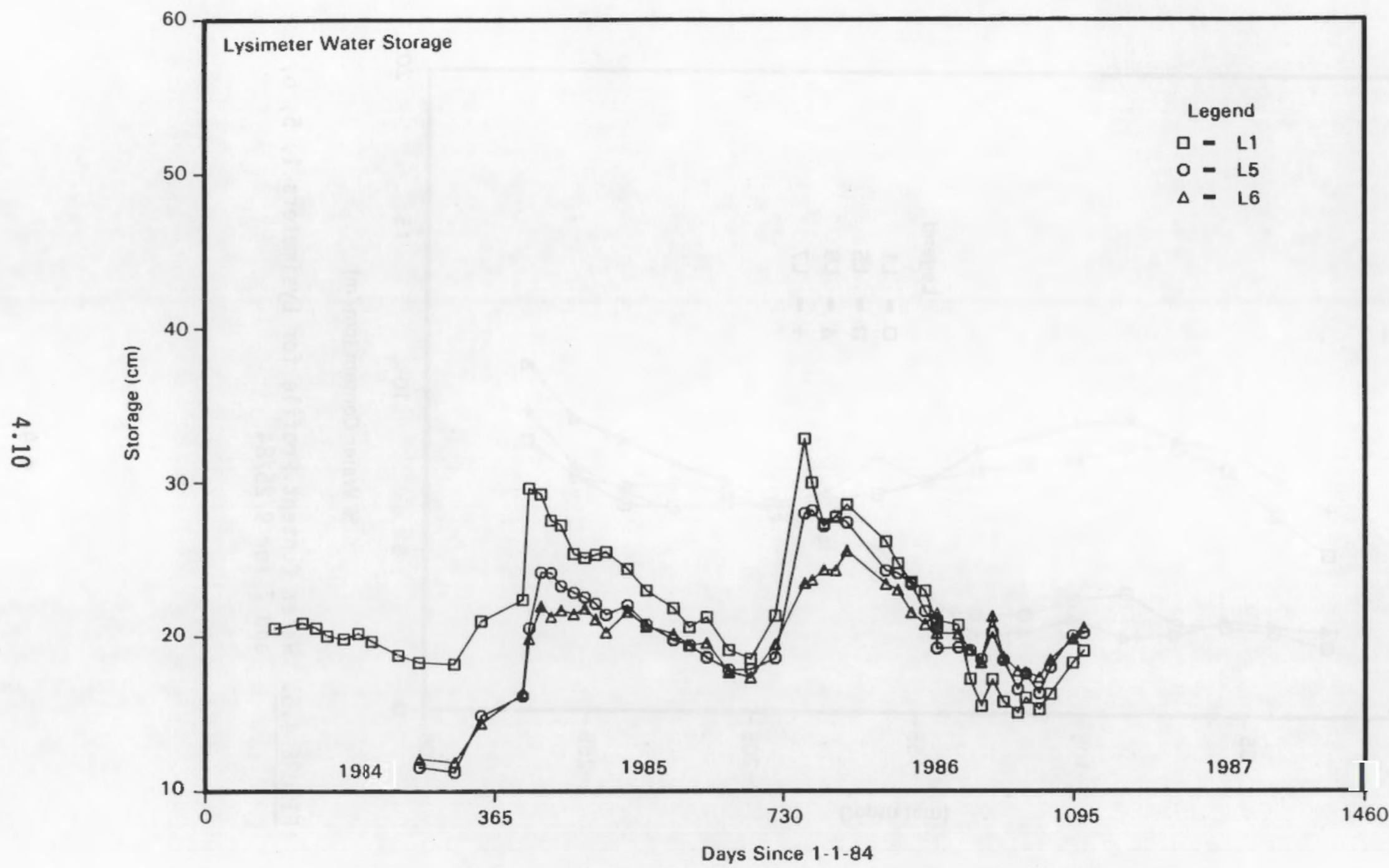

FIGURE 4.6. Profile Water Storage for Lysimeters, 1, 5, and 6 


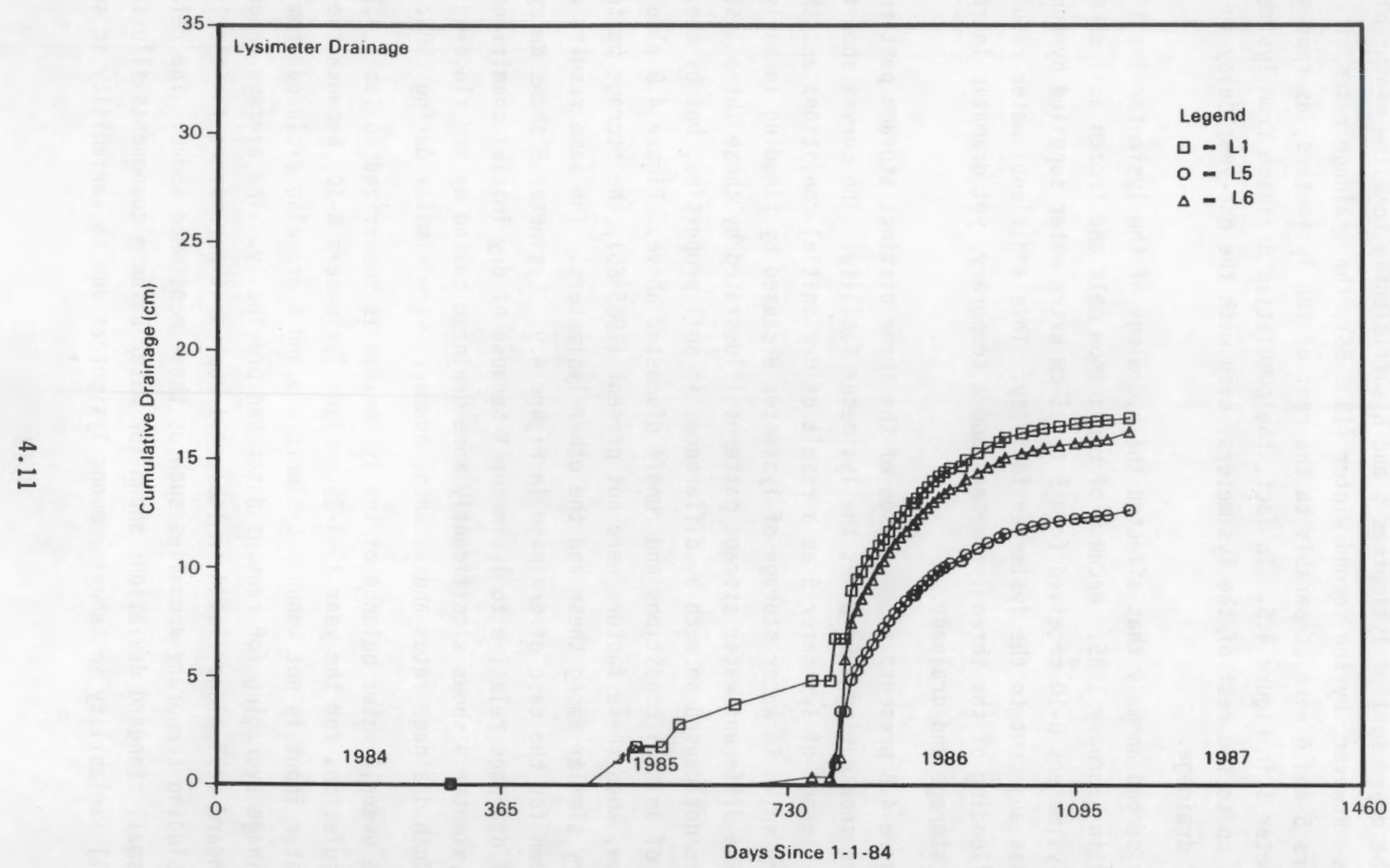

FIGURE 4.7. Cumulative Drainage for Lysimeters 1, 5, and 6 
because the precipitation received during the winter of 1984-85 was not enough to wet the dryer soil of lysimeters 5 and 6 sufficiently to allow measurable drainage. However, by the second winter (1985-86), the drainage rates of lysimeters 5 and 6 were comparable to the rest of the lysimeters, as represented by lysimeter 1 in Figure 4.5. In fact, the cumulative drainage from lysimeter 6 caught up to the rest of the lysimeters, even with the one-year delay in the start of drainage.

The second anomaly that affected the hydrology of the lysimeter facility occurred in February 1985. Because of rapid snow melt and frozen soil conditions, lysimeters $8-10$ received from 5 to $15 \mathrm{~cm}$ extra water supplied by runoff from areas adjacent to the lysimeter facility. This additional water resulted in the flooding of the three lysimeters and a temporary, yet dramatic increase, in both storage and drainage.

Figure 4.8 presents a comparison of the three distinct storage patterns that were seen during 1984-85 at the lysimeter facility. The curves show the reduced storage of lysimeter 5 as a result of dry initial conditions and the temporary spike in water storage of lysimeter 9 caused by flooding in early 1985. The different water storage patterns illustrated by these three lysimeters were not caused so much by differences in soil properties, but by the factors of initial conditions and runoff discussed above. Figure 4.8 also shows how, when these factors were not present (1985-86), the storage patterns were very similar among these and the other lysimeters. The same results are also shown for the case of drainage in Figure 4.9. Lysimeter 5 shows delayed onset of drainage relative to lysimeter 1 because of dry initial conditions while lysimeter 9 shows significantly more drainage caused by the flooding of 1985. Both drainage rates and amounts, however, were similar during 1986.

The overall water balance of the lysimeters is summarized in Table 4.1. The calculations for the year 1984-85 exclude lysimeters 8-10, because the exact water input is not known. Lysimeters 5 and 6 are also excluded from the drainage averaging for reasons discussed previously. The average values and standard deviations listed in Table 4.1 represent parameters for the lysimeters excluding temporary anomalies such as those mentioned above. The relatively small standard deviations shown for water balance components illustrate the small variability in behavior among lysimeters due to variability in soil 


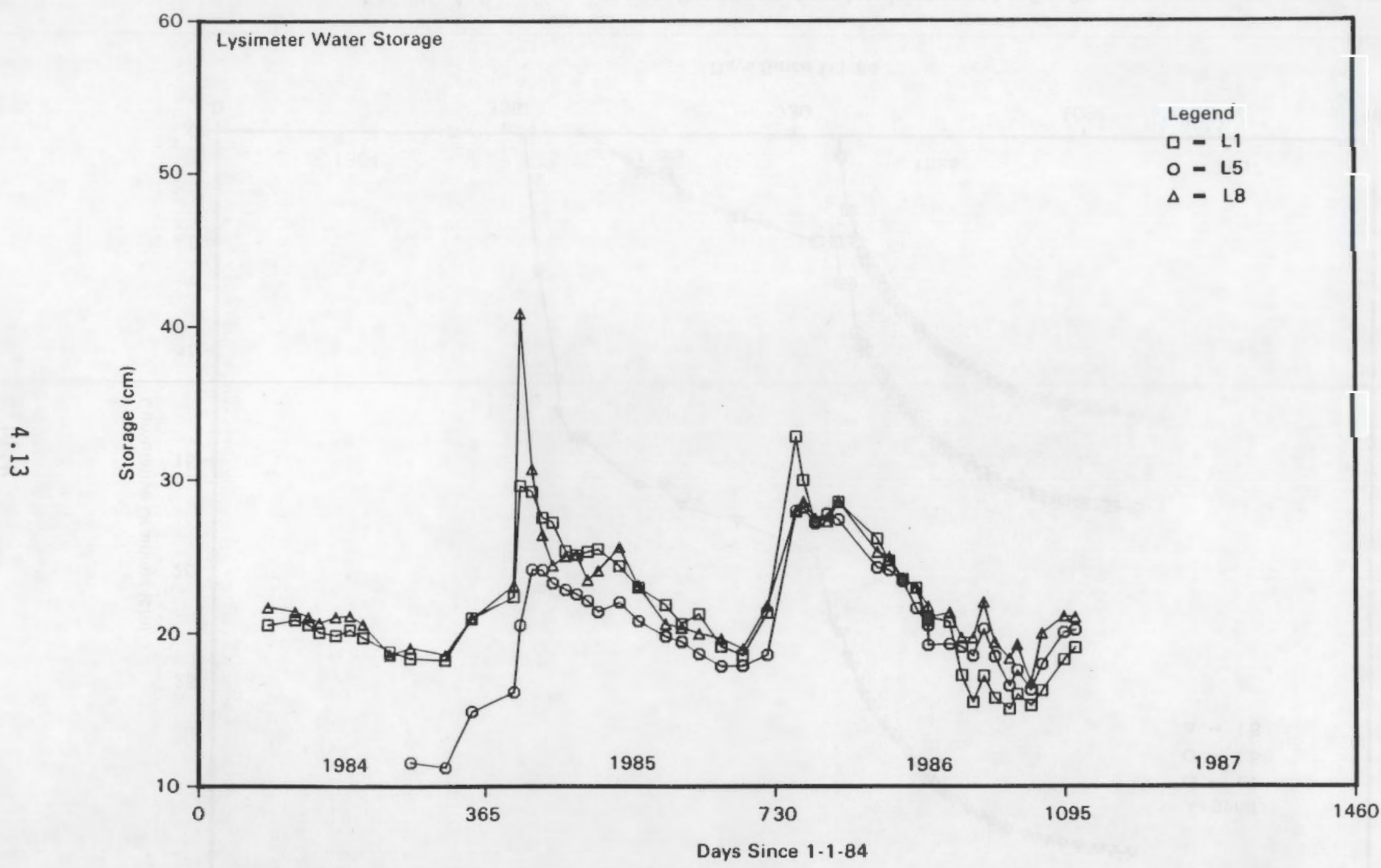

FIGURE 4.8. Profile Water Storage for Lysimeters 1, 5, and 8 


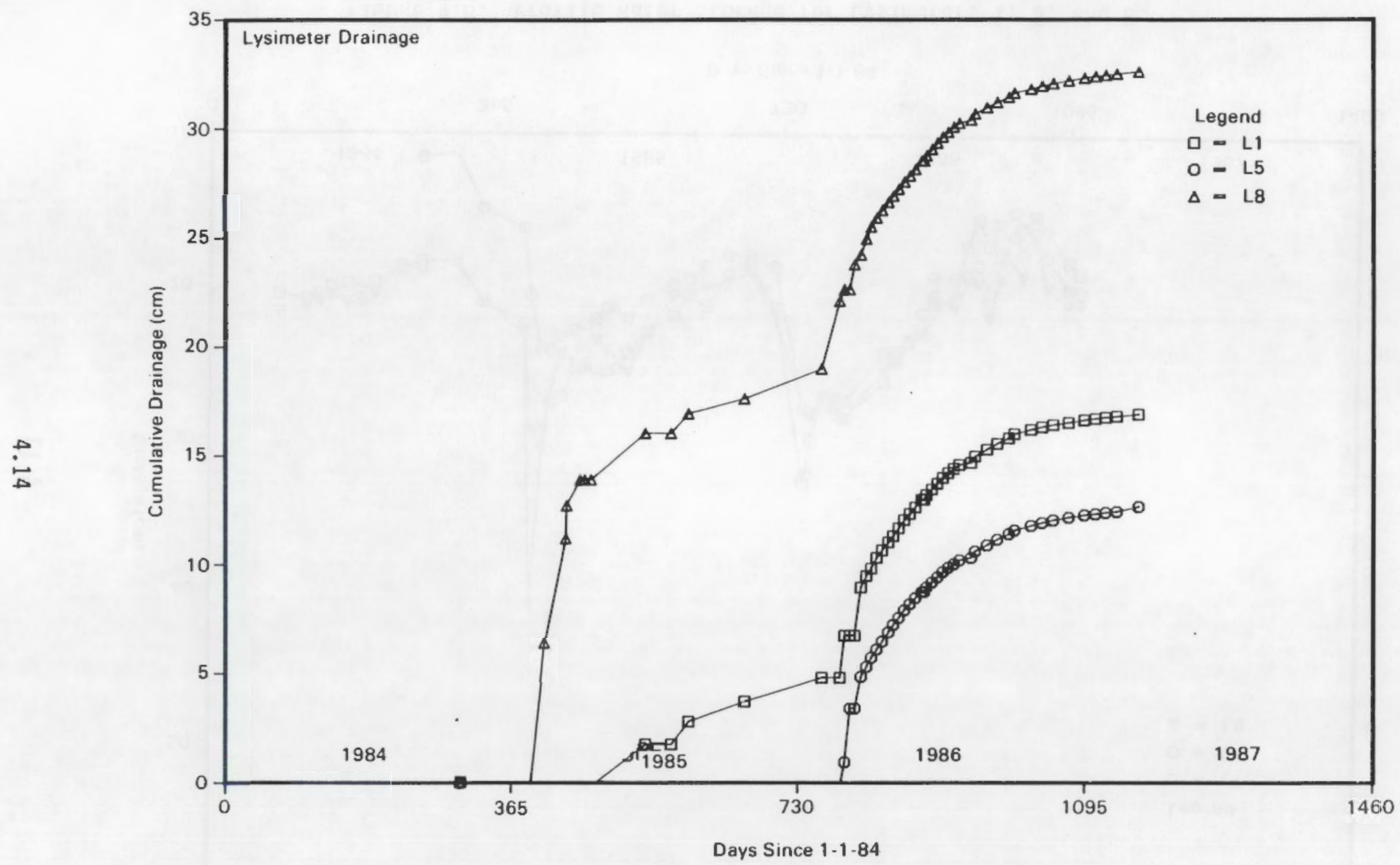

FIGURE 4.9. Cumulative Drainage for Lysimeters 1, 5, 8 
properties. Another interesting observation is the similarity in estimated evaporation for the 2 years, even though 1985-86 received 50\% more precipitation. This similarity illustrates the complex relationship that exists among precipitation and either drainage or evaporation. In this case, it is because of the extra precipitation in the form of snow, and quickly entering the soil as snow melt during late winter when evaporation was low.

The seasonal changes in total water storage shown above correspond to changes in average soil water contents. As shown in Table 4.1, the volumetric water content at the depth of the waste samples ranged from 7 to $11 \%$ in both years. This is a fairly narrow range considering the significant amount of drainage water moving through the soil profile. However, this is typical of coarse soils. Drainage rates also fluctuate during the year. The annual rates shown in Table 4.1 are annual averages. During 1986, the drainage rate ranged from a high of over $1 \mathrm{~cm} / \mathrm{wk}$ in February to less than $0.05 \mathrm{~cm} / \mathrm{wk}$ in November.

\subsection{WATER BALANCE PARAMETERS RELEVANT TO TRANSPORT}

Two contaminant transport processes are known to vary with water content and drainage rate. The first is hydrodynamic dispersion. This is the process

TABLE 4.1. Average Water Balance Parameters for 1984-1986.

\begin{tabular}{lcc} 
& $9 / 1 / 84(\mathrm{a})$ & $9 / 1 / 85$ \\
& to & to \\
& $8 / 31 / 85$ & $8 / 31 / 86$ \\
& 13.8 & 21.7 \\
\hline $\begin{array}{l}\text { total precip, cm } \\
\text { snow, cm }\end{array}$ & 55.6 & 86.6 \\
& & $-0.6 \pm 2.2$ \\
$\begin{array}{l}\Delta \text { storage, cm } \\
\text { drainage, cm } \\
\text { evaporation, cm }\end{array}$ & $2.1 \pm 0.5$ & $12.3 \pm 1.2$ \\
$\begin{array}{l}\Delta \text { water content, cm/m } \\
\Delta \text { matric potential, cm }\end{array}$ & $7.5 \pm 0.5=11.4$ & $10.0 \pm 2.8$ \\
& -40 to -80 & $6.9-10.7$ \\
\end{tabular}

(a) Calculations for $9 / 1 / 84$ to $8 / 31 / 85$ are only for lysimeters $1,2,3,4$, and 7 . 
that causes a solute pulse to spread (i.e., disperse) as it moves through a soil profile. It is usually characterized by a dispersion coefficient, which is commonly modeled as a linear function of pore water velocity. Pore water velocity in the case of the lysimeters is the drainage rate divided by the volumetric water content. Winter drainage rates are associated with a water content of about $11 \%$ and summer rates with $7 \%$. Therefore, pore water velocities are ranging from a high of $\sim 1 \mathrm{~cm} / \mathrm{wk}$ to less than $0.05 \mathrm{~cm} / \mathrm{wk}$. This change in pore water velocity can result in an order of magnitude change in dispersion.

The other transport parameter thought to vary with water content is solute retardation. The most popular model for sorption and transport of radionuclides in soil is the linear Freundlich isotherm combined with the classical convective-dispersive equation. In this model, sorption is expressed as a retardation factor $R$, defined as the ratio of water velocity to solute velocity. The usual formulation expresses $R$ as inversely proportional to volumetric water content. A change in water content of 7 to $11 \%$ would reduce the retardation factor by $60 \%$. Therefore, in the winter when drainage rates are at their highest, sorption and retardation may be at their lowest. 


\subsection{WASTE-FORM LEACHING RESULTS}

Leachate samples are collected from the lysimeter drains at regular intervals (currently every 2 weeks) and analyzed for radioactive elements. A complete chemical analysis (ICP and IC) is done quarterly. The results of these analyses are summarized in this section. Complete listings of these data are presented in Appendix C and Appendix D.

\subsection{RADIONUCLIDE MIGRATION}

Drainage water collected from the bottom of each lysimeter is analyzed for radionuclide content as one measure of release and transport. Tritium and cobalt-60 are the only radionuclides identified in any of the leachates. Tritium is part of the source inventory of only the boric acid/masonry cement waste forms and is present in the leachate of lysimeters 1 and 7 , which contain samples of this waste form. The total amount collected from the bottom of the lysimeters represents approximately $30 \%$ of the estimated tritium inventory of these waste forms.

Cobalt-60 is present in all waste streams, but is a primary constituent in the sodium sulfate evaporator concentrate waste streams. Cobalt-60 has been identified in all four cement waste forms constructed with the concentrate or concentrate plus exchange resin (lysimeter 2,8 and 3, 9, respectively). Cobalt- 60 has also been detected in one of the lysimeters containing a polymer waste form (lysimeter 4). The total amount of cobalt-60 collected from the lysimeters is less than $0.1 \%$ of the estimated cobalt- 60 inventory for each of the waste forms. Complete data on the radionuclide concentrations and cumulative migration is given in Appendix C.

The pattern of radionuclide release from the lysimeters is shown in Figures 5.1 through 5.4. The cumulative release is plotted versus time and also versus cumulative drainage from each of the lysimeters. Figure 5.1 shows the release of tritium from lysimeters 1 and 7 versus time. The total amount and temporal pattern of tritium arrival at the lysimeter drain are nearly identical for each lysimeter. Figure 5.1 indicates that there is a seasonal nature to tritium arrival at the lysimeter drain. More tritium arrives at the lysimeter bottom with the spring drainage of winter precipitation and snowmelt than with the 


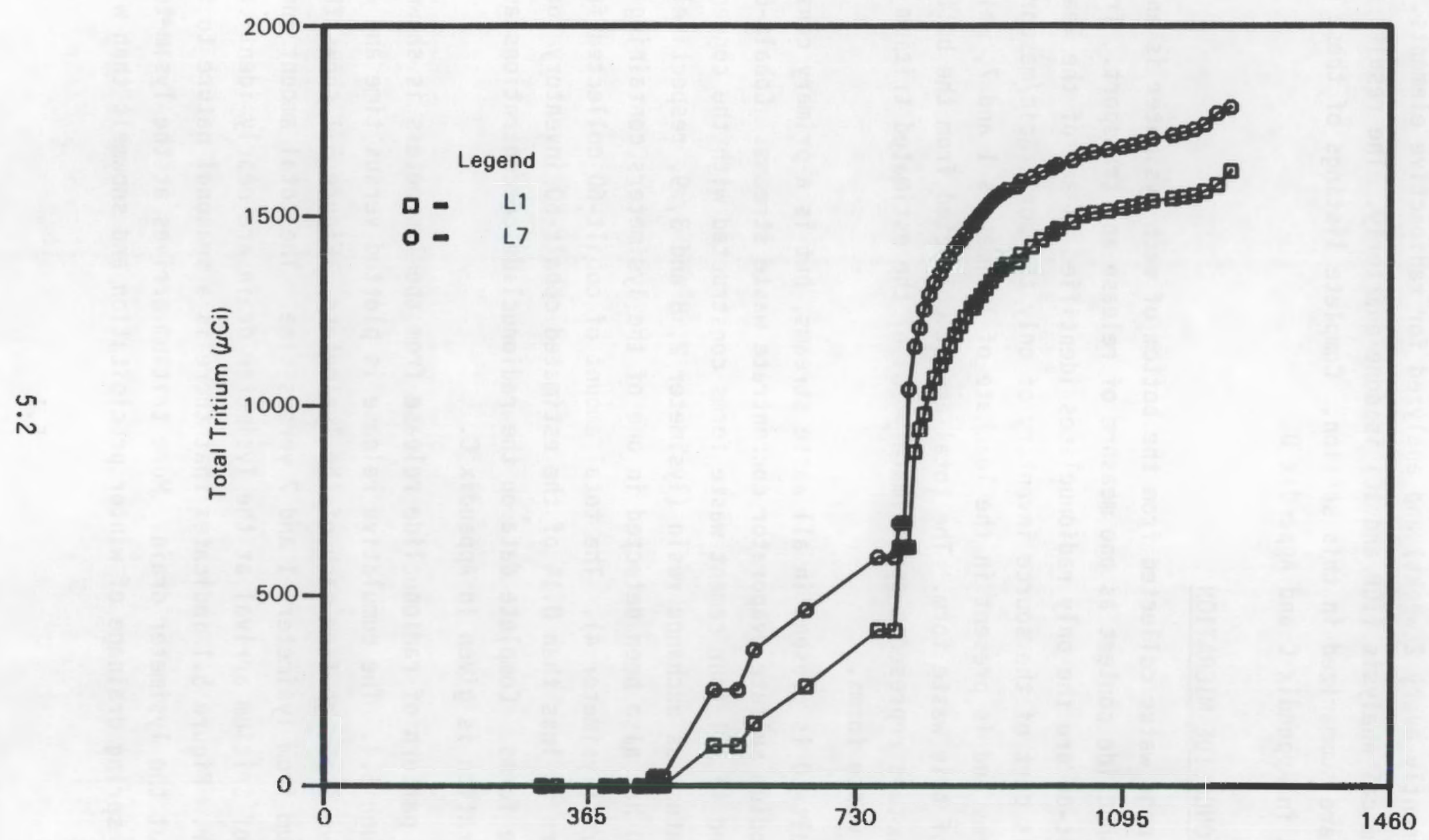

Days Since 1-1-84

FIGURE 5.1. Cumulative Release of Tritium from Lysimeter 1 and 7 Versus Time 
drainage water arriving in the summer and fall. This seasonal variability is essentially eliminated when the cumulative amount of tritium is plotted or normalized by the cumulative drainage (Figure 5.2). Figure 5.2 shows that there is less variability in the amount of tritium contained in a unit of drainage water than drains in a unit of time.

The pattern of cobalt-60 drainage is shown in Figures 5.3 and 5.4. Drawing source term conclusions from these curves is more speculative than for the tritium because these releases represent less than $0.1 \%$ of the total inventory of cobalt in the waste forms. Lysimeters 3 and 9 are replicate lysimeters that contain the same waste form; this is also true of lysimeters 2 and 8 . These replicate lysimeters seem to be releasing similar amounts of cobalt. Figures 5.3 and 5.4 show less variability in cumulative release among replicate lysimeters than among waste forms. The replicate of lysimeter 4 is lysimeter 10 , which has not shown any levels of cobalt above limits of detection. The polymer waste forms (lysimeters 4 and 10) are releasing less cobalt than the cernent (lysimeters 2,8 and 3,9$)$. The higher amount of cobalt released from lysimeters 3 and 9 relative to lysimeters 2 and 8 is probably due to the higher cobalt inventory of lysimeters 3 and 9 .

Figure 5.3 indicates a seasonal variability in drainage as was discussed above for tritium. The possible conclusions are also the same. Mobile cobalt-60 is generally thought to result from complex formation with some chelating agent. Chelating agents are present in the waste steams and the formation of complexes is a likely possibility. Solubility controls do not seem plausible for the mobile fraction of the cobalt. A comparison of Figure 5.3 with Figure 5.4 shows that the release is more strongly dependent on time than on cumulative drainage. The flooding of lysimeters 8,9 , and 10 does not seem to have had much effect on total amount or time of release. A cumulative release that depends more on time than drainage seems more consistent with some sort of diffusion-controlled source term although more data and extensive modeling will be necessary to confirm the most representative source term formulation. 


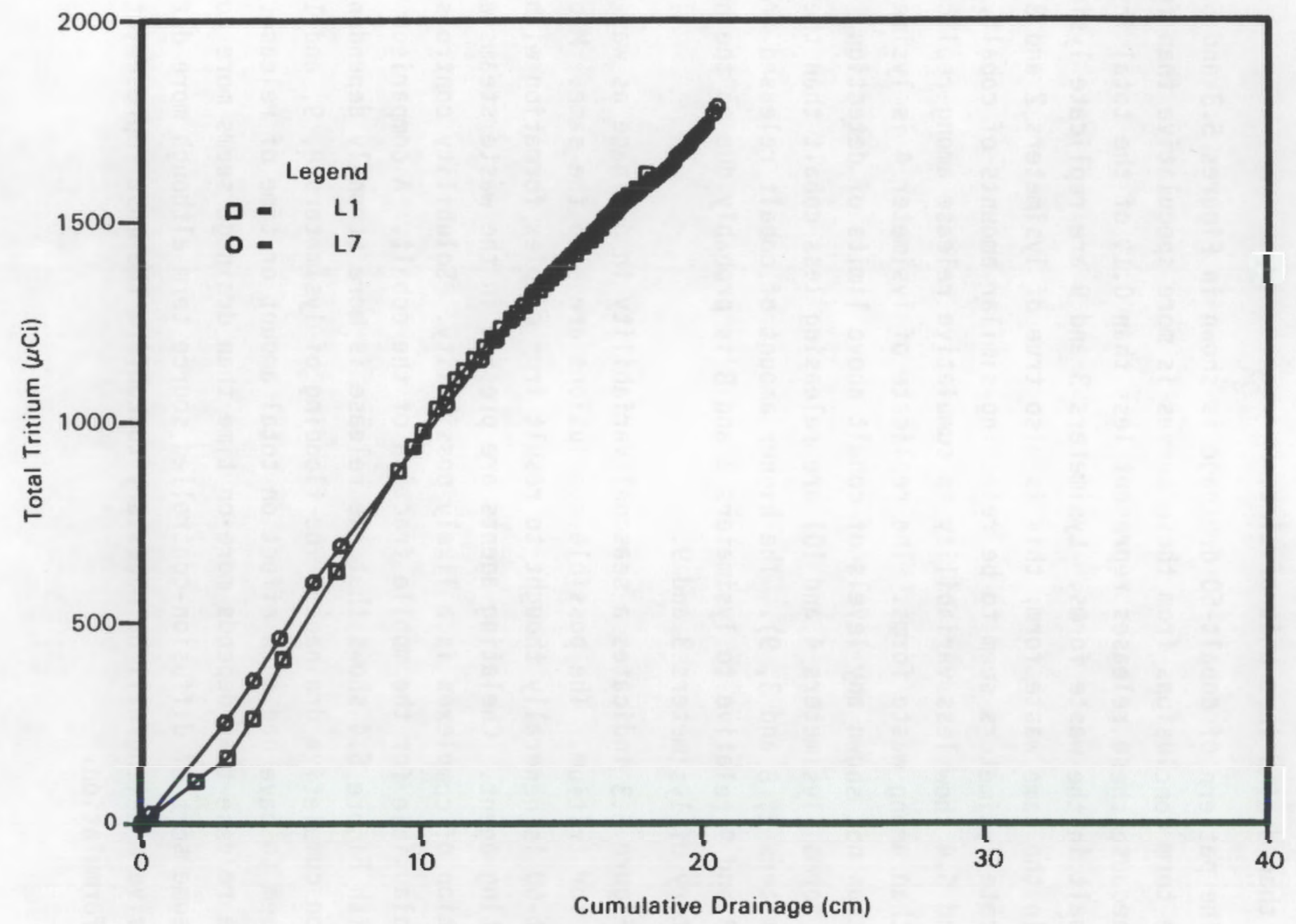

FIGURE 5.2. Cumulative Release of Tritium from Lysimeters 1 and 7 versus Cumulative Drainage 


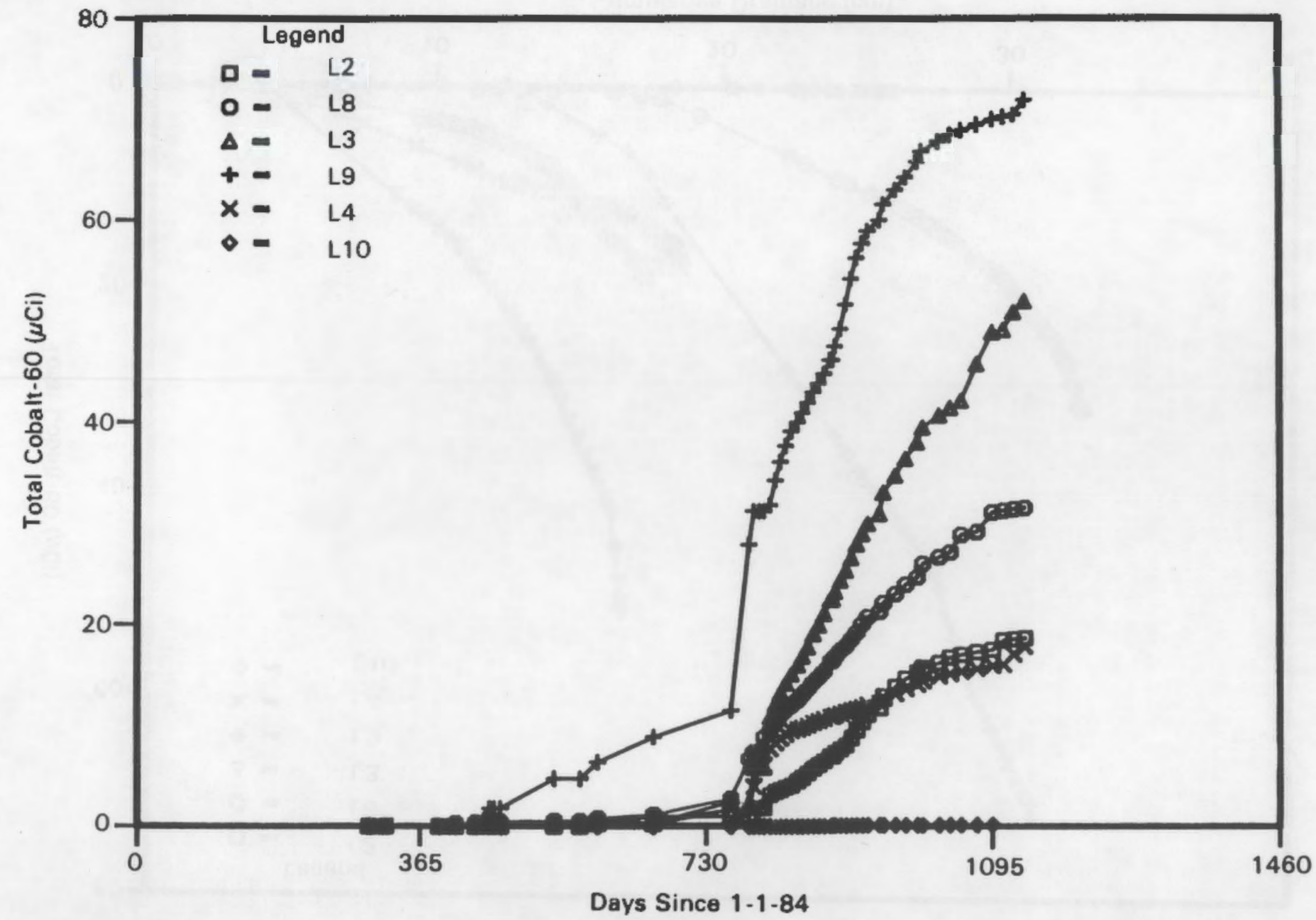

FIGURE 5.3. Cumulative Release of Cobalt-60 from Lysimeters $2,3,4,8$, and 9 Versus Time 


$$
24
$$




\subsection{MIGRATION OF NONRADIOACTIVE ELEMENTS}

The waste forms buried in the SWLA lysimeters contain significant amounts of nonradioactive components in addition to the radioactive waste. These components leach from the waste form and migrate to the lysimeter drain and are detected in the lysimeter leachate. Monitoring the release of the nonradioactive components is important for two reasons. First, obtaining a complete chemical inventory of leachate samples allows application of geochemical models to identify speciation and solubility processes controlling leachate composition. Lysimeter leachates will be analyzed by the geochemical model MINTEQ (Peterson et al. 1987) in the same way as leachates from this program's laboratory leaching experiments were analyzed by Criscenti and Serne (1987). The second importance of complete chemical analysis is that the nonradioactive components provide additional leachable components useful in developing and evaluating source term and transport models.

A sumnary of the cumulative amounts of nonradioactive components identified in the lysimeter leachate is presented in Table 5.1. A more complete listing of leachate chemistry is found in Appendix $D$. The data in Table 5.1 can only be analyzed qualitatively without the use of MINTEQ and transport models; however, some interesting trends can be observed.

A comparison of Table 2.14 with Table 5.1 shows that the cumulative release of several components exceeds estimated inventory. This implies that the soil and/or the solidification agents in the lysimeters are also a source of these constituents. These components include calcium, magnesium, strontium, and nitrate. These constituents are known to leach from the soil material used to fill the lysimeters and laboratory experiments are under way to try to estimate this effect.

Two particularly interesting components listed in Table 5.1 are sodium and sulfate. All wastes contain these two constituents, particularly the sodium sulfate evaporator concentrate found in lysimeters $2,3,4,8,9$, and 10. Table 5.1 shows that between 10 and $15 \%$ of the total inventory of sulfate has leached from all waste forms. This is in spite of the fact that the total inventory of sulfate varies by as much as a factor of 5 among different waste forms. Also, the effect of the flooding of lysimeters 8,9 , and 10 appears to 
TABLE 5.1. Total Amount of Nonradioactive Elements Leached from Lysimeters

\begin{tabular}{|c|c|c|c|c|c|c|c|c|c|}
\hline Drum & $\mathrm{Ca}$ & $\mathrm{Na}$ & K & $\mathrm{Mg}$ & $\mathrm{Sr}$ & $\mathrm{NO}_{3}$ & $\mathrm{SO}_{4}$ & $\mathrm{Cl}$ & B \\
\hline$-1 B$ & 41.4 & 12.3 & 4.9 & 9.8 & 0.17 & 99.2 & 23.0 & 2.1 & 0.06 \\
\hline$-I B$ & 152.0 & 198.6 & 8.3 & 42.2 & 0.65 & 48.2 & 764.6 & 14.0 & 0.02 \\
\hline-18 & 163.6 & 309.5 & 8.2 & 50.5 & 0.70 & 23.2 & 1114.3 & 18.3 & 0.02 \\
\hline$-2 B$ & 163.8 & 170.4 & 8.2 & 41.5 & 0.71 & 34.8 & 675.2 & 20.6 & 0.05 \\
\hline Drum 1 & 21.7 & 9.1 & 4.0 & 5.0 & 0.10 & 34.1 & 17.5 & 1.4 & 4.28 \\
\hline Drum 2 & 39.0 & 12.7 & 4.7 & 9.4 & 0.18 & 54.2 & 21.9 & 2.5 & 8.89 \\
\hline $4-2 B$ & 40.1 & 14.1 & 5.1 & 8.2 & 0.21 & 76.6 & 29.4 & 2.3 & 0.10 \\
\hline $1-2 B$ & 147.3 & 290.9 & 24.3 & 54.3 & 0.79 & 33.7 & 1021.1 & 21.2 & 0.05 \\
\hline $2-2 B$ & 152.5 & 392.0 & 28.1 & 53.9 & 0.82 & 46.4 & 1143.8 & 23.1 & 0.04 \\
\hline$-3 B$ & 46.3 & 20.3 & 3.0 & 10.9 & .21 & 7.5 & 78.9 & 3.5 & 0.04 \\
\hline
\end{tabular}

have had little effect in accelerating the release of sulfate from these three lysimeters. The small increase in the leaching of nonradioactive chemicals from the flooded lysimeters relative to the nonflooded lysimeters is similar to the lack of excess leaching of cobalt-60 from the flooded lysimeters discussed above.

The leaching of sodium is interesting because of the small amount of sodium found in leachate samples relative to sulfate levels and to sodium inventories. Percentage of sodium inventories leached is only comparable to sulfate leaching in lysimeters 1 and 7 (approximately $12 \%$ ). In all other lysimeters, the amount of sodium leached out of the lysimeters ranges from 2 to $4 \%$. One possible explanation of this is the interaction of sodium with calcium leaching out of the waste form and also calcium occurring naturally in the soil. Sodium will compete with calcium for soil exchange sites. Normally, calcium will compete more effectively and little or no sodium will be sorbed onto soil clays. However, when soluble sodium levels are high, calcium can be displaced from soil exchange sites and sodium become the dominant exchange bound cation. It appears that this is happening to a certain extent in the SWLA lysimeters. This 
displacing of soil calcium is one explanation for the high calcium levels found in leachate samples relative to calcium inventories in the waste forms. Another possible explanation of the high calcium levels would be dissolution of the cement in Tysimeters $2,3,8$, and 9 .

Examining the two boric acid waste forms provides some indication of how the solidification agent can affect release of solutes. The two elements of interest are sodium and boron. As mentioned above, the boric acid/masonry cement samples (drums $4-1 B$ and $4-2 B$ ) show the highest percentage of sodium leaching. One explanation has already been given that has to do with the low inventories of sodium, preventing sodium from competing effectively with calcium for soil exchange sites. If this is a viable explanation of leachate composition in lysimeters 1 and 7 , then there must be some other explanation for the relatively low leaching percentage for drums $\# 1$ and $\# 2$ (lysimeters 5 and 6 ). These samples also have low sodium inventories.

Lysimeters 5 and 6 contain the boric acid/bitumen waste forms. Laboratory leaching studies indicate that unless the bitumen is crushed or physically degraded, most solutes are physically trapped inside the complex structure of the bitumen. Therefore, the low leaching percentage for sodium may be the result of the waste form retarding release rather than the soil retarding transport as with the other cement waste forms.

The second element of interest in the boric acid waste forms is boron. Table 2.14 shows that both boric acid waste streams have significant amounts of boron. However, the leaching percentage is low for all four lysimeters containing these waste forms (Table 5.1). Boron is not likely to be retarded by the soil in any significant amount because it travels as a neutral or anionic species. The low leaching percentage is an indication of low release rates from the waste forms. It has been speculated that boron can be tied up with solid phases in cement and therefore its solution concentration is controlled at a low level by solubility relationships. This could be the explanation relevant to samples $4-1 B$ and $4-2 B$. In the case of the bitumen waste form (samples \#1 and \#2), the explanation is likely to be physical entrapment in the bitumen structure rather than solubility control.

There is much more to be learned from the leachate results presented here. However, a more detailed understanding of why the leachate composition 
is as measured and how leachate composition relates to source term functions will require more quantitative analysis. This analysis will come from applying geochemical modeling, as described above, as well as using solute release and transport models to simulate leachate results. The iterative process of simulation and calibration is the only way to document which types of source term models and which specific release parameters will effectively support low-level waste performance assessments. 


\subsection{REFERENCES}

ANS. 1986. Measurement of the Leachability of Solidified Low-Level Radioactive Wastes by a Short-Term Test Procedure, American Nuclear Socjety, Standards Committee, Working Group, ANSI/ANS 16.1, Champaign, Illinois.

Brodzinski, R. L., R. W. Perkins, H. G. Rieck and N. A. Wogman. 1987. "Measurement of Radionuclides in Waste Packages." U.S. Patent 4617169.

Brodzinski, R. L. 1986. An Instrument for Assaying the Radionuclide Concentrations in 208-1iter Drums. PNL-SA-13572S, Pacific Northwest Laboratory, Richland, Washington - presented at ANS Society Meeting, Reno, Nevada, June 1986.

Criscenti, L. J. and R. J. Serne, 1987. Geochemical Analysis of Leachates From Cement-Low Level Radioactive Waste-Soil Systems. PNL-6544, Pacific Northwest Laboratory, Richland, Washingtion.

Mualem, Y. 1976. "A New Model for Predicting the Hydraulic Conductivity of Unsaturated Porous Media." Water Resour. Res. 12(3):513-522.

NRC. 1986. Licensing Requirements for Land Disposal of Radioactive Waste, 10 CFR Part 61, U.S. Nuclear Regulatory Commission, Washington, D.C.

Peterson, S. R., C. J. Hostetler, W. J. Deutsch and C. E. Cowan. 1987. MINTEQ User's Manual. NUREG/CR-4808, U.S. Nuclear Regulatory Commission, Washington D.C.

Toste, A. P., T. R. Pah1, R. B. Lucke and R. B. Myers. 1987. Analysis of Complex Organic Mixtures in Nuclear Wastes. To be published in Proceedings of 24th Hanford Life Sciences Symposium, PNL-SA-13078, Pacific Northwest Laboratory, Richland, Washington.

van Genuchten, Rien. 1978. Calculating the Unsaturated Hydraulic Conductivity with a New Closed-Form Analytical Model. 78-WR-08, Department of Civil Engineering, Princeton University.

Walter, M.B., M.J. Graham and G.W. Gee. 1984. A Field Lysimeter Facility for Evaluating the Performance of Commercial Solidified Low-Level Waste. PNL-5253, Pacific Northwest Laboratory, Richland, Washington.

Walter, M. B., R. J. Serne, T. L. Jones and S. B. Mclaurine. 1986. Chemical Characterization, Leach, and Adsorption Studies of Solidified Low-Level Wastes. PNL-6047, Pacific Northwest Laboratory, Richland, Washington. 


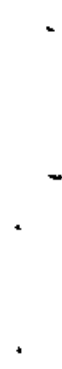




\section{APPENDIX A}

DETAILED ORGANIC ANALYSIS OF COMMERCIAL

REACTOR WASTE STREAMS

(summarized from Toste et a1. 1987) 
APPENDIX A

\section{DETAILED ORGANIC ANALYSIS OF COMMERCIAL REACTOR WASTE STREAMS}

The material presented in this appendix is summarized and in some cases excerpted from Toste et al. (1987). Shortly after PNL received the liquid waste samples from BNL, aliquots were sent to Dr. Anthony Toste (PNL) for complete organic analyses.

The samples were a mixture of liquid and solids. Each phase was further broken into two categories: hydrophilic and hydrophobic. The supernatant solution was extracted with chloroform to remove hydrophobic organic compounds; this extract, the hydrophobic organic fraction, was concentrated and set aside for analys is by GC and combined GC-MS. The extracted water sample, containing hydrophilic organic compounds, was evaporated to dryness under nitrogen. The residue of each aqueous fraction was then methylated in a sealed reaction vial with $1 \mathrm{~mL}$ of $\mathrm{BF}_{3} /$ methanol $(14 \% \mathrm{w} / \mathrm{v})$ at $100^{\circ} \mathrm{C}$ for 40 minutes. After cooling, I $\mathrm{mL}$ of chloroform was added, the mixture was transferred to a test tube containing $3 \mathrm{~mL}$ of $1 \mathrm{M} \mathrm{KH}_{2} \mathrm{PO}_{4}$ buffer solution ( $\mathrm{pH} 7$ ) with a $0.2 \mathrm{~mL}$ chloroform rinse and vortexed. Part of the chloroform layer $(0.6 \mathrm{~mL})$, which contained the methylated hydrophilic organic compounds, was then evaporated under nitrogen. The residue of this dried sample was immediately redissolved in chloroform, yielding the hydrophilic organic extract. This extract was analyzed by GC and GC-MS.

About $2 \mathrm{~g}$ of each commercial waste solid phase was extracted by stirring with distilled-deionized water at $\mathrm{pH} 11$ for 48 hours. The alkaline extract of the solids was then prepared as just described for the liquid phases, again yielding a hydrophobic and hydrophilic extract.

GC Analysis. GC analyses were performed on a Hewlett-Packard (HP) 5880 gas chromatograph equipped with a $30 \mathrm{~m} \times 0.25 \mathrm{~mm}$ I.D. fused-silica capillary column coated with a $0.25-\mu m$ film of DB-5 and a splitiess injection system. From an initial value of $40^{\circ} \mathrm{C}$, the column temperature was programmed at $20^{\circ} \mathrm{C}$ per minute for 3 minutes to $100^{\circ} \mathrm{C}$, followed by $8^{\circ} \mathrm{C}$ per minute for 25 minutes to $300^{\circ} \mathrm{C}$, and finally maintained isothermally at $300^{\circ} \mathrm{C}$ for 10 minutes. 
GC-MS Analysis. GC-MS analyses were performed on an HP 5985 GC-MS instrument in the electron-impact $(70-\mathrm{eV})$ mode. The gas chromatograph on the 5985 instrument was equipped with a $60 \mathrm{~m} \times 0.25 \mathrm{~mm} \mathrm{1.D.} \mathrm{fused} \mathrm{silica} \mathrm{capillary} \mathrm{column}$ coated with $0.25 \mu \mathrm{m}$ of SE-54; the column was programmed from $40^{\circ} \mathrm{C}$ to $300^{\circ} \mathrm{C}$ at $5^{\circ} \mathrm{C}$ per minute, where it was maintained isothermally for 8 minutes. A splitless injection system was used to introduce the sample into the GC-MS instrument. A mass range of 50 to 400 atomic mass units (AMU) was scanned every second by the computer (HP-7920 large disc drive).

GC/FTIR. Analyses were performed on a Nicolet 60SX FTIR (Nicolet Analytical Instruments, Madison, WI) instrument equipped with a Nicolet 1280 computer and interfaced to an HP $5840 \mathrm{GC}$. The GC was equipped with a widebore, fused silica capillary column (10 m $\times 0.53$ mn I.D. coated with a 1.5- $\mu m$ film of $0 \mathrm{~V}-17)$ and a splitless injection system, which was maintained at $200^{\circ} \mathrm{C}$. The GC column temperature was programmed from $40^{\circ} \mathrm{C}$ to $250^{\circ} \mathrm{C}$ at $30^{\circ} \mathrm{C}$ per minute. HeTium was used as the carrier gas at $5 \mathrm{~mL}$ per minute. The temperature of the GC/FTIR interface was maintained at $250^{\circ} \mathrm{C}$. The FTIR instrument was operated at a resolution of $8 \mathrm{~cm}^{-1}$ with a scan rate of 2 scans per second over a wavenumber range of 5000 to $700 \mathrm{~cm}^{-1}$. The temperature of the light pipe was maintained at $200^{\circ} \mathrm{C}$.

Quantitation. The organic species identified by the GC-MS analyses were quantitated by GC (with flame ionization detection) analysis using internal and external standards representative of compounds identified by GC-MS. Pure compounds representative of the various compound classes identified by GC-MS were selected as standards and methylated. A specific amount (1-2 $\mu \mathrm{L})$ of each starldard was co-injected with each sample to confirm the GC-MS identifications. To quantify, each standard was aiso injected onto the gas chromatograph prior to and following sample analyses. The response factor of each standard was calculated under analytical conditions identical to those of the sample analyses.

The results are summarized in Tables A.2 and A.3. The wastes were described by Toste et al. (1987) differently than the names that were used in the main text of this report. The names used in Tables A.2 and A.3 correspond as follows: 


\begin{tabular}{lc}
\multicolumn{1}{c}{ Main Text } & Appendix A \\
\hline Boric acid \#1 & PWR \\
Evaporator concentrate & BWR1 \\
Concentrate with resin & BWR2
\end{tabular}

The samples consisted of the percentage of solids and liquids shown in Table A.1. The table compares the percentages determined by Toste et al. to those determined by BNL when the wastes were obtained at the reactors.

Various hydrophobic organic compounds were identified, particularly in the BWR wastes, at relatively high concentrations (ppm, Table A.2). The two most abundant types of compounds are a class of alkylphenols and two classes of alkylphenyl phosphate esters. The latter were the prominent, or characteristic, classes in the BWR wastes, but a number of alkylphenols were also present in the solid phase of the boric acid \#1 waste. These compounds are commonly used as hydraulic fluids and plasticizers. The liquid phase of the boric acid $\# 1$ waste contained few identifiable hydrophobic organic compounds. The two BWR wastes differed; the solid phase of evaporator concentrate contained most of the hydrophobic organic species (149.9 ppm versus $49.1 \mathrm{ppm}$ for the solid and liquid phases, respectively), whereas the liquid phase of concentrate with resin contained most of the hydrophobic species (109 ppm versus $56.30 \mathrm{ppm}$ for the liquid and solid phases, respectively). These observations confirm the need to perform thorough source-term characterization on wastes. Related wastes may vary with respect to chemical content, making simplistic predictions about their leachability meaningless.

Various hydrophilic compounds, consisting mainly of organic acids, were identified in the commercial wastes (Table A.3). No hydrophilic species were identified in the solid phase of the boric acid $\# 1$.

The predominant class of hydrophilic organics identified are chelating agents, which were characteristic of the boric acid \#1 waste. EDTA and the chelator fragment ED3A are the major components; nine other chelator fragments were also identified at concentrations ranging from 0.1 to $17.9 \mu \mathrm{M}(39.3 \mu \mathrm{M}$ 
TABLE A.1. Phase Distribution in Waste Streams

\begin{tabular}{|c|c|c|c|c|}
\hline & \multicolumn{2}{|c|}{ Toste et al. } & \multicolumn{2}{|c|}{ BNL } \\
\hline & $\begin{array}{r}\text { Organ } \\
\text { Liquid, } \%\end{array}$ & $\begin{array}{l}\text { Aliquots } \\
\text { Solid, }\end{array}$ & $\begin{array}{l}\text { Original } \\
\text { Liquid, }\end{array}$ & $\begin{array}{l}\text { alysis } \\
\text { Solid, }\end{array}$ \\
\hline Boric acid \#1 & 96 & 4 & 94.5 & 5.5 \\
\hline Evaporator concentrate & 63 & 37 & 74 . & 26 . \\
\hline Concentrate with resin & 47 & 53 & 61.6 & 38.4 \\
\hline
\end{tabular}

TABLE A.2. Hydrophobic Organic Compounds Identified in Commercial Nuclear Wastes From Nuclear Power Reactors

Concentration,_PPm $(a)$
$\frac{\text { PWR Waste }}{\text { Liquid Solid }} \frac{\text { BWR Waste No. } 1}{\text { Liquid Solid }}$ BWR Waste No. 2
Liquid Solid

Alkyl Phenols

Cresol (methylphenol)

Dimethylphenols $(3)^{(b)}$

Ethylphenol

$C_{2}-$ phenols $(6)^{(b)}$

2,6(di-t-buty1)4-ethylphenol

4-methy 1, 2-nitrophengl

Ethylnitrophenols $(3)^{(b)}$

Phosphate Esters

$\begin{array}{rrrrr}1.5 & 3.2 & 25.8 & 4.3 & 5.9 \\ 11.1 & 1.3 & 14.4 & 0.7 & 16.2 \\ 7.1 & 3.9 & 8.8 & 1.7 & 9.5 \\ & 10.8 & 89.7 & 16.3 & 17.2 \\ 0.3 & & 1.3 & & 0.5 \\ & & 6.4 & & \end{array}$

1.6

73.2

15.4

11.1

2.9

(22) (b)

Phthalate Esters

Dioctylphthalate

Dimethylphthalates (2) ${ }^{(b)}$

A]kylphthalate

Hydroxybenzaldehyde

$\mathrm{N}-$ (pheny $\mathrm{l}$, methy $\mathrm{l}$ ) amine

Benzene sulfonamide

Polyethylene glycol
33.2

46.0
1.5

$0.2 \quad 1.2$

(a) No entry indicates compound was below detection level (0.1 ppb).

(b) Number of compounds identified. 
TABLE A.3 Hydrophilic Organic Compounds ${ }^{(a)}$ Identified in Commercial Nuclear Wastes From Nuclear Power Reactors

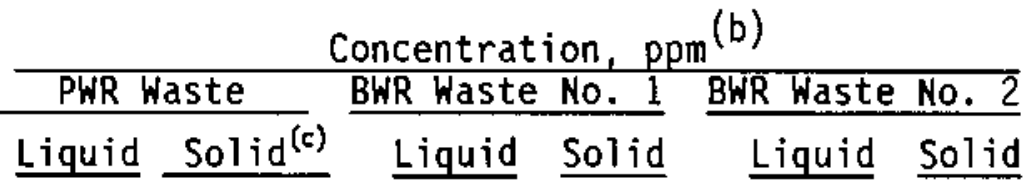

Chelating Agents (a)

\begin{tabular}{|c|c|}
\hline $\begin{array}{l}\text { Ethylenediaminetetraacetic } \\
\text { acid (EDTA) }\end{array}$ & 11.2 \\
\hline $\begin{array}{l}\text { Ethylenediaminetriacetic } \\
\text { acid (ED3A) }\end{array}$ & 22.5 \\
\hline Iminodiacetic acid (IDA) & 0.2 \\
\hline $\begin{array}{l}\mathrm{N}-(2-\text { Hydroxyethy } 1) \text { iminodia- } \\
\text { cetic acid (HEIDA) }\end{array}$ & \\
\hline $\begin{array}{l}\text { N-Methylethylenediamine-N, } N^{\prime}- \\
\text { diacetic acid }\left(\operatorname{MeEDD}^{\prime} A\right)\end{array}$ & 6.4 \\
\hline $\begin{array}{l}\text { N-Methylethy lenediamine-N, } N^{\prime}- \\
\text { diactic acid (MeDDA) }\end{array}$ & \\
\hline Chelator fragments ${ }^{(d)}$ & \\
\hline
\end{tabular}

Tricarboxylic Acids (a)

Methane Tricarboxylic Acid

Citric acid

7.8

$\begin{array}{lll}7.1 & 1.8 & 0.4\end{array}$

$2.1 \quad 66.8$

1.8

Diacarboxylic Acids $($ a)

Oxalic acid

Propanedioic acid

Methylpropanedioic acid

Hydroxypentanedioic acid

Maleic acid

Butanedioic acid

Methylbutanedioic acid

Hydroxybutanedioic acid

2-Ketoglutaric acid

Hexanedioic acid

octanedioic acid

Nonanedioic acid

0.2

$11.2 \quad 76.5$

$2.1 \quad 16.5$

0.8

0.7

0.2

4.1

0.4

$\begin{array}{lll}5.0 & 21.0 & 0.4\end{array}$

$\begin{array}{lll}5.9 & 47.6 & 4.8\end{array}$

$\begin{array}{lll}3.7 & 18.8 & 1.7\end{array}$

0.03

15.3

11.5

9.3

2.7

3.9

10.5

2.1

11.2

6.5

0.8

3.2

2.9

0.2

0.2

Monocarboxylic Acids (a)

2-Methylpropanoic acid

8.6

0.8

Butanoic acid

2-Butenoic acid

1.5

8.0

0.4 
IABLE A.3. (contd)

\begin{tabular}{|c|c|c|c|c|c|}
\hline \multirow[b]{3}{*}{ Monocarboxylic Acids (a) } & \multicolumn{5}{|c|}{ Concentration, $\mathrm{ppm}(\mathrm{b})$} \\
\hline & PWR Waste & BWR Wast & No. & BWR Waste & No. \\
\hline & Liquid Solid & Liquid & Solid & Liquid & Soli \\
\hline lethylbutanoic acid & & 1.1 & 25.3 & & \\
\hline -Butanoic acid & & & & & 0.6 \\
\hline $\begin{array}{l}\text {-Pentenoic acid } \\
\text { lexanoic acid }\end{array}$ & & 0.5 & 7.6 & & \\
\hline -Ethylexanoic acid & & & 2.2 & & \\
\hline ctanoic acid & & & 15.1 & & 0.70 \\
\hline Inanoic acid & & & 12.8 & & 1.1 \\
\hline odecanoic acid & & & & & 0.9 \\
\hline $\begin{array}{l}\text { exadecanolc acid } \\
\text { ctadecanoic acid }\end{array}$ & & & $\begin{array}{l}41.0 \\
17.9\end{array}$ & & \\
\hline
\end{tabular}

Oxygenated Acids (a)

Glycolic acid

Lactic Acid

5.3

0.6

2-Hydroxypropanoic acid

3-Hydroxybutanoic acid

Glyoxylic acid

Pyruvic acid

3-Hydroxypentanoic acid

4-Methyl,1,2-oxopentanoic acid

2.1

19.0

$12.3 \quad 73.6$

3.8

14.5

20.2

Furancarboxylic acid

4-0xopentanoic acid

5-0xoproline

\section{3}

$1.8 \quad 1.3$

\section{Aromatic Acids (a)}

Benzoic acid

Methylbenzoic acid

Benzeneacetic acid

2-Hydroxybenzeneacetic acid
$13.3 \quad 28.6$

$\begin{array}{rr} & 3.5 \\ 2.7 & 12.1\end{array}$

1.4
0.6

0.3

$18.3 \quad 3.4$

\section{2}

3.4

\section{1}

Ketones

3-Methy],3-hydroxy, 2-butenone

4-Methoxybenzaldehyde

4-Hydroxy, pheny 1, 1-ethanone

1.4

1.4

3.6

3.3

(a) Mehylated ( $\mathrm{BF}_{3} /$ methano) acids identified as methyl esters.

(b) No entry indicates compound was below detection level $(0.1 \mathrm{ppb})$.

(c) Solid phase of waste from PWR contained no identifiable hydrophilic organics.

(d) Four unknown compounds detected: A) unknown, $1.0 \mathrm{ppm}$; B) unknown, $1.7 \mathrm{ppm} ;$ C) MW 247 species, $17.9 \mathrm{ppm} ;$ D) MW 318 species, $1.4 \mathrm{ppm}$. 
collectively). Of the nine chelator fragments, Toste et al. (1987) have identified the structure of four: 1) IDA, $0.2 \mathrm{ppm}$; 2) HEIDA, $0.1 \mathrm{ppm}$; 3) MeEDD'A, $6.4 \mathrm{ppm} ;$ and 4) MeEDDA, $2.8 \mathrm{ppm}$. The five unknown fragments include a MW-190 species; $7.8 \mathrm{ppm}$; a MW-247 species, $17.9 \mathrm{ppm}$; a MW-318 species (possibly a lactam), $1.4 \mathrm{ppm} ;$ and two other unspecified species, 7.8 and $1.7 \mathrm{ppm}$.

The boric acid \#1 waste contained more ED3A and other chelator fragments than nondegraded EDTA, presumably reflecting greater chemical/radiolytic decomposition of EDTA than the BWR wastes. In contrast, most hydrophilic organic species were found in the liquid phase of the concentrate with resin waste $(55.0$ ppm versus $16.4 \mathrm{ppm}$ for the liquid and solid phases, respectively). A similar trend was observed for the hydrophobic organic fraction. 
*

.

.

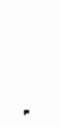

$\therefore$ 


\section{APPENDIX B}

SOIL-WATER CONTENT OF LYSIMETERS

MEASURED BY NEUTRON PROBE 


\section{SOIL-WATER CONTENT OF LYSIMETERS}

MEASURED BY NEUTRON PROBE

The following listing of data are soil-water contents as measured by a Mode 1503 Hydroprobe manufactured by Campbell Pacific Nuclear. Data shown covers the period of March 1984 through January 1987. Lysimeters 5 and 6 were not filled until September 1984; therefore, no data are available until then. The row of data marked AVG $\%$ is the average water content calculated for the entire lysimeter. The row marked WASTE $\%$ is the average water content measured over the length of the waste forms (183- to $244-\mathrm{cm}$ readings). The row marked STRG $\mathrm{cm}$ is the total amount of water stored in the lysimeter where the volume of soil in the lysimeter has been corrected for the volume of the waste form. 
DATE: $\quad 03-27-84$

DAY: $\quad 87$

PROBE: $\quad 2499$ STANDARD COUNTS: 17063

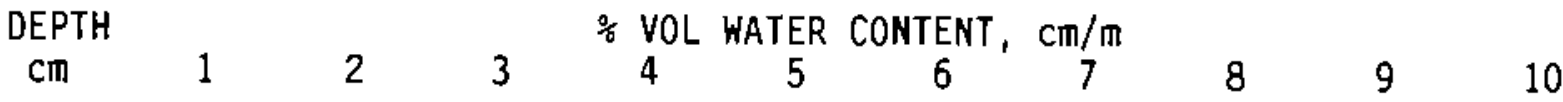

$\begin{array}{lllllllllll}30.0 & 9.8 & 9.6 & 9.6 & 7.2 & 0.0 & 0.0 & 9.1 & 7.7 & 9.2 & 9.4\end{array}$ $\begin{array}{lllllllllll}46.0 & 11.1 & 10.9 & 10.6 & 7.6 & 0.0 & 0.0 & 10.0 & 11.0 & 10.1 & 10.9\end{array}$ $\begin{array}{lllllllllll}61.0 & 10.1 & 9.6 & 10.7 & 7.0 & 0.0 & 0.0 & 10.5 & 10.8 & 10.2 & 11.1\end{array}$ $\begin{array}{lllllllllll}76.0 & 8.4 & 8.6 & 8.8 & 6.9 & 0.0 & 0.0 & 8.4 & 9.0 & 9.8 & 10.6\end{array}$ $\begin{array}{lllllllllll}91.0 & 7.3 & 7.6 & 7.2 & 7.0 & 0.0 & 0.0 & 7.8 & 7.6 & 8.4 & 9.5\end{array}$ $\begin{array}{lllllllllll}107.0 & 7.3 & 7.6 & 7.6 & 6.1 & 0.0 & 0.0 & 7.5 & 7.3 & 7.3 & 8.1\end{array}$ $\begin{array}{lllllllllll}122.0 & 7.3 & 7.3 & 7.7 & 5.5 & 0.0 & 0.0 & 7.3 & 7.7 & 7.0 & 6.7\end{array}$ $\begin{array}{lllllllllll}137.0 & 6.9 & 7.5 & 7.5 & 5.7 & 0.0 & 0.0 & 7.2 & 7.2 & 7.2 & 6.5\end{array}$ $\begin{array}{lllllllllll}152.0 & 7.2 & 8.4 & 7.3 & 6.4 & 0.0 & 0.0 & 7.4 & 7.3 & 7.7 & 7.1\end{array}$ $\begin{array}{lllllllllll}167.0 & 7.2 & 7.8 & 7.7 & 6.9 & 0.0 & 0.0 & 6.8 & 7.5 & 8.0 & 7.0\end{array}$ $\begin{array}{lllllllllll}183.0 & 7.3 & 7.1 & 7.8 & 7.1 & 0.0 & 0.0 & 6.8 & 7.6 & 7.7 & 7.3\end{array}$ $\begin{array}{lllllllllll}198.0 & 7.0 & 7.1 & 7.7 & 7.6 & 0.0 & 0.0 & 6.5 & 8.4 & 8.5 & 8.1\end{array}$ $\begin{array}{lllllllllll}213.0 & 7.6 & 7.0 & 8.1 & 8.3 & 0.0 & 0.0 & 6.7 & 9.1 & 9.2 & 7.6\end{array}$ $\begin{array}{lllllllllll}229.0 & 7.0 & 7.6 & 7.4 & 8.0 & 0.0 & 0.0 & 6.5 & 8.6 & 9.1 & 7.5\end{array}$ $\begin{array}{lllllllllll}244.0 & 7.2 & 8.1 & 7.9 & 8.3 & 0.0 & 0.0 & 7.1 & 8.3 & 8.4 & 7.3\end{array}$ $\begin{array}{lllllllllll}259.0 & 8.1 & 9.6 & 9.2 & 9.2 & 0.0 & 0.0 & 8.7 & 8.9 & 9.2 & 8.2\end{array}$ $\begin{array}{lllllllllll}274.0 & 9.8 & 10.2 & 10.5 & 8.8 & 0.0 & 0.0 & 11.0 & 11.4 & 9.5 & 9.9\end{array}$

$\begin{array}{lllllllllll}\text { AVG \% } & 7.5 & 7.7 & 7.8 & 6.7 & 0.0 & 0.0 & 7.3 & 7.9 & 8.1 & 7.8\end{array}$ $\begin{array}{lllllllllll}\text { WASTE \% } & 7.2 & 7.6 & 7.7 & 7.5 & 0.0 & 0.0 & 6.8 & 8.1 & 8.4 & 7.4\end{array}$

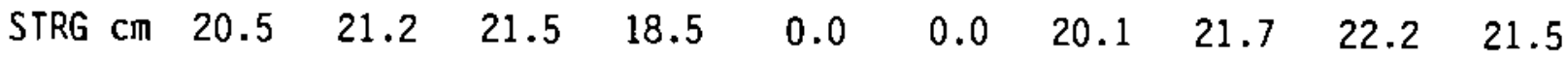


DATE: $\quad 05-02-84$

DAY: $\quad 122$

PROBE: $\quad 5140$ STANDARD COUNTS: 11254

\begin{tabular}{|c|c|c|c|c|c|c|c|c|c|c|}
\hline $\begin{array}{l}\text { DEPTH } \\
\mathrm{cm}\end{array}$ & 1 & 2 & 3 & $\begin{array}{c}\text { VOL } \\
4\end{array}$ & $\begin{array}{l}\text { ER CO } \\
5\end{array}$ & $\begin{array}{l}\text { ENT, } \\
6\end{array}$ & $\frac{m}{m} / m$ & 8 & 9 & 10 \\
\hline 30.0 & 9.0 & 9.0 & 9.3 & 6.6 & 0.0 & 0.0 & 8.7 & 9.1 & 8.6 & 8.1 \\
\hline 46.0 & 10.0 & 10.7 & 10.3 & 7.2 & 0.0 & 0.0 & 9.3 & 10.3 & 10.1 & 9.8 \\
\hline 61.0 & 11.2 & 10.8 & 10.6 & 7.7 & 0.0 & 0.0 & 10.1 & 10.6 & 10.1 & 10.4 \\
\hline 76.0 & 10.6 & 9.5 & 10.4 & 7.7 & 0.0 & 0.0 & 10.0 & 9.7 & 10.3 & 10.2 \\
\hline 91.0 & 8.8 & 8.4 & 9.8 & 7.2 & 0.0 & 0.0 & 9.1 & 8.6 & 9.6 & 9.3 \\
\hline 107.0 & 7.1 & 7.8 & 9.1 & 7.5 & 0.0 & 0.0 & 8.0 & 8.0 & 8.6 & 9.4 \\
\hline 122.0 & 7.2 & 7.8 & 8.2 & 6.3 & 0.0 & 0.0 & 7.4 & 6.9 & 7.5 & 8.2 \\
\hline 137.0 & 7.1 & 7.3 & 7.3 & 5.4 & 0.0 & 0.0 & 6.7 & 7.2 & 7.3 & 7.2 \\
\hline 152.0 & 7.3 & 7.6 & 7.6 & 6.3 & 0.0 & 0.0 & 7.0 & 6.8 & 7.5 & 7.0 \\
\hline 167.0 & 7.3 & 7.6 & 7.6 & 7.5 & 0.0 & 0.0 & 6.4 & 7.0 & 7.8 & 7.0 \\
\hline 183.0 & 6.6 & 7.4 & 7.5 & 7.2 & 0.0 & 0.0 & 6.3 & 7.0 & 7.5 & 6.9 \\
\hline 198.0 & 6.9 & 7.7 & 8.1 & 7.8 & 0.0 & 0.0 & 6.1 & 7.9 & 8.4 & 7.7 \\
\hline 213.0 & 7.2 & 7.7 & 8.4 & 8.3 & 0.0 & 0.0 & 6.3 & 8.3 & 8.8 & 7.3 \\
\hline 229.0 & 7.1 & 7.4 & 7.7 & 7.8 & 0.0 & 0.0 & 6.0 & 8.3 & 8.5 & 7.2 \\
\hline 244.0 & 7.1 & 8.3 & 7.9 & 7.9 & 0.0 & 0.0 & 6.5 & 7.8 & 8.5 & 7.1 \\
\hline 259.0 & 8.3 & 9.1 & 9.1 & 8.8 & 0.0 & 0.0 & 8.1 & 8.8 & 9.2 & 8.2 \\
\hline 274.0 & 10.0 & 10.4 & 10.7 & 8.7 & 0.0 & 0.0 & 10.5 & 10.6 & 9.3 & 9.5 \\
\hline AVG \% & 7.6 & 7.9 & 8.2 & 6.9 & 0.0 & 0.0 & 7.2 & 7.8 & 8.1 & 7.7 \\
\hline NASTE \% & 7.1 & 7.7 & 7.8 & 7.5 & 0.0 & 0.0 & 6.4 & 7.6 & 8.2 & 7.2 \\
\hline STRG cm & 20.8 & 21.7 & 22.5 & 18.9 & 0.0 & 0.0 & 19.7 & 21.4 & 22.4 & 21.2 \\
\hline
\end{tabular}


DATE: $\quad 05-18-84$

DAY: $\quad 139$

PROBE: $\quad 5140 \quad$ STANDARD COUNTS: 11254

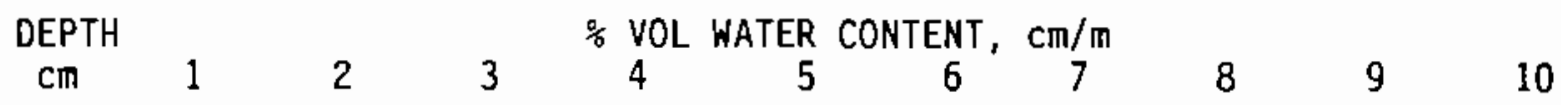

$\begin{array}{lllllllllll}30.0 & 8.3 & 7.7 & 8.5 & 5.7 & 0.0 & 0.0 & 8.5 & 8.6 & 7.9 & 7.5\end{array}$

$\begin{array}{lllllllllll}46.0 & 10.4 & 10.1 & 9.6 & 7.8 & 0.0 & 0.0 & 8.9 & 9.8 & 9.5 & 10.0\end{array}$

$\begin{array}{lllllllllll}61.0 & 11.2 & 9.9 & 10.7 & 7.7 & 0.0 & 0.0 & 9.5 & 10.3 & 10.2 & 10.3\end{array}$

$\begin{array}{lllllllllll}76.0 & 10.1 & 9.7 & 10.0 & 7.9 & 0.0 & 0.0 & 9.6 & 9.8 & 10.2 & 10.4\end{array}$

$\begin{array}{lllllllllll}91.0 & 8.8 & 8.9 & 9.8 & 7.5 & 0.0 & 0.0 & 9.5 & 9.1 & 9.7 & 10.0\end{array}$

$\begin{array}{lllllllllll}107.0 & 7.9 & 8.2 & 9.6 & 7.6 & 0.0 & 0.0 & 8.7 & 8.0 & 8.8 & 9.7\end{array}$

$\begin{array}{lllllllllll}122.0 & 7.1 & 8.0 & 7.9 & 6.6 & 0.0 & 0.0 & 7.2 & 7.2 & 7.7 & 8.3\end{array}$

$\begin{array}{lllllllllll}137.0 & 6.7 & 7.2 & 7.6 & 6.3 & 0.0 & 0.0 & 7.1 & 7.0 & 7.2 & 7.5\end{array}$

$\begin{array}{lllllllllll}152.0 & 7.2 & 7.4 & 7.5 & 6.7 & 0.0 & 0.0 & 6.9 & 6.9 & 7.6 & 7.5\end{array}$

$\begin{array}{lllllllllll}167.0 & 7.2 & 7.8 & 7.8 & 6.7 & 0.0 & 0.0 & 6.6 & 6.8 & 7.7 & 7.2\end{array}$

$\begin{array}{lllllllllll}183.0 & 7.1 & 7.8 & 7.4 & 7.0 & 0.0 & 0.0 & 6.3 & 7.0 & 7.9 & 6.8\end{array}$

$\begin{array}{lllllllllll}198.0 & 6.7 & 6.8 & 7.5 & 7.5 & 0.0 & 0.0 & 6.4 & 7.7 & 8.4 & 7.4\end{array}$

$\begin{array}{lllllllllll}213.0 & 6.7 & 6.9 & 7.6 & 7.8 & 0.0 & 0.0 & 6.3 & 8.0 & 8.5 & 7.6\end{array}$

$\begin{array}{lllllllllll}229.0 & 6.3 & 7.4 & 7.6 & 7.3 & 0.0 & 0.0 & 6.4 & 7.9 & 8.5 & 6.7\end{array}$

$\begin{array}{lllllllllll}244.0 & 7.3 & 8.0 & 7.2 & 7.6 & 0.0 & 0.0 & 6.7 & 7.6 & 9.1 & 7.4\end{array}$

$\begin{array}{lllllllllll}259.0 & 8.0 & 9.0 & 8.7 & 8.7 & 0.0 & 0.0 & 8.0 & 8.5 & 9.2 & 8.7\end{array}$

$\begin{array}{lllllllllll}274.0 & 9.6 & 10.3 & 10.7 & 8.8 & 0.0 & 0.0 & 10.4 & 10.5 & 8.7 & 9.5\end{array}$

$\begin{array}{lllllllllll}\text { AVG } \% & 7.5 & 7.7 & 7.9 & 6.8 & 0.0 & 0.0 & 7.2 & 7.7 & 8.1 & 7.8\end{array}$ $\begin{array}{lllllllllll}\text { WASTE } \% & 6.9 & 7.5 & 7.5 & 7.2 & 0.0 & 0.0 & 6.5 & 7.4 & 8.2 & 7.2\end{array}$

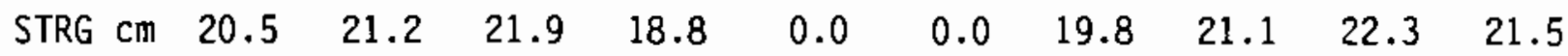




$$
\begin{array}{lc}
\text { DATE: } & 06-01-84 \\
\text { DAY: } & 153
\end{array}
$$

\begin{tabular}{|c|c|c|c|c|c|c|c|c|c|c|}
\hline $\begin{array}{l}\text { DEPTH } \\
\mathrm{cm}\end{array}$ & 1 & 2 & 3 & $\begin{array}{l}\text { VOL W } \\
4\end{array}$ & $\begin{array}{l}\text { ER CO } \\
5\end{array}$ & $\begin{array}{l}\text { ENT, } \\
6\end{array}$ & $\frac{\pi}{\pi} / \frac{\pi}{7}$ & 8 & 9 & 10 \\
\hline 30.0 & 7.7 & 7.5 & 7.9 & 5.3 & 0.0 & 0.0 & 7.7 & 7.7 & 7.3 & 7.3 \\
\hline 46.0 & 9.1 & 9.9 & 9.6 & 7.4 & 0.0 & 0.0 & 8.9 & 8.9 & 9.1 & 9.1 \\
\hline 61.0 & 10.3 & 10.4 & 10.6 & 7.4 & 0.0 & 0.0 & 9.4 & 9.4 & 9.4 & 9.8 \\
\hline 76.0 & 10.1 & 10.3 & 10.2 & 7.5 & 0.0 & 0.0 & 9.0 & 9.0 & 9.9 & 9.7 \\
\hline 91.0 & 9.3 & 9.5 & 9.7 & 7.2 & 0.0 & 0.0 & 9.1 & 9.1 & 9.6 & 9.5 \\
\hline 107.0 & 7.5 & 9.3 & 9.2 & 7.3 & 0.0 & 0.0 & 8.5 & 8.5 & 9.2 & 9.4 \\
\hline 122.0 & 7.5 & 8.4 & 8.2 & 7.0 & 0.0 & 0.0 & 7.5 & 7.5 & 7.3 & 8.5 \\
\hline 137.0 & 6.9 & 7.9 & 7.5 & 6.2 & 0.0 & 0.0 & 6.7 & 6.9 & 7.1 & 8.0 \\
\hline 152.0 & 6.8 & 7.3 & 7.3 & 6.5 & 0.0 & 0.0 & 6.8 & 7.0 & 7.1 & 7.6 \\
\hline 167.0 & 7.1 & 7.9 & 7.4 & 7.2 & 0.0 & 0.0 & 6.6 & 6.7 & 7.2 & 7.0 \\
\hline 183.0 & 6.7 & 7.8 & 7.4 & 6.7 & 0.0 & 0.0 & 6.3 & 6.7 & 7.8 & 7.0 \\
\hline 198.0 & 6.7 & 7.6 & 7.5 & 7.2 & 0.0 & 0.0 & 6.3 & 7.9 & 7.8 & 7.4 \\
\hline 213.0 & 6.7 & 7.5 & 7.3 & 7.4 & 0.0 & 0.0 & 5.7 & 7.9 & 8.4 & 7.0 \\
\hline 229.0 & 6.2 & 7.1 & 7.3 & 7.7 & 0.0 & 0.0 & 6.2 & 7.7 & 7.6 & 7.1 \\
\hline 244.0 & 6.8 & 7.2 & 7.6 & 8.3 & 0.0 & 0.0 & 6.0 & 8.2 & 8.2 & 7.3 \\
\hline 259.0 & 8.3 & 7.7 & 8.5 & 8.6 & 0.0 & 0.0 & 7.8 & 8.6 & 9.1 & 8.5 \\
\hline 274.0 & 9.3 & 9.8 & 10.7 & 8.6 & 0.0 & 0.0 & 9.6 & 10.7 & 9.1 & 9.9 \\
\hline AVG \% & 7.3 & 7.8 & 7.8 & 6.7 & 0.0 & 0.0 & 7.0 & 7.5 & 7.8 & 7.7 \\
\hline WASTE \% & 6.7 & 7.5 & 7.4 & 7.3 & 0.0 & 0.0 & 6.3 & 7.4 & 7.7 & 7.2 \\
\hline STRG $\mathrm{cm}$ & 20.0 & 21.6 & 21.6 & 18.6 & 0.0 & 0.0 & 19.1 & 20.6 & 21.4 & 21.1 \\
\hline
\end{tabular}

PROBE: $\quad 5140$ STANDARD COUNTS: 11317 
DATE: $\quad 06-22-84$

DAY: $\quad 174$

PROBE: $\quad 5140$ STANDARD COUNTS: 11280

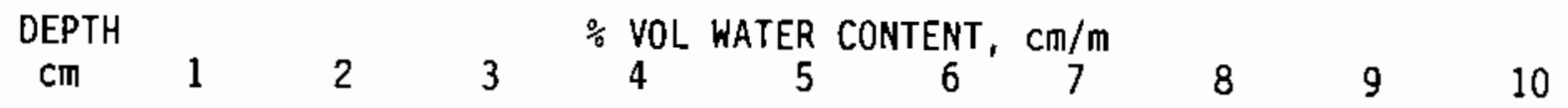

$\begin{array}{lllllllllll}30.0 & 6.8 & 7.1 & 7.3 & 5.0 & 0.0 & 0.0 & 7.4 & 7.6 & 7.1 & 6.7\end{array}$

$\begin{array}{lllllllllll}46.0 & 9.2 & 8.9 & 9.4 & 6.3 & 0.0 & 0.0 & 9.2 & 9.4 & 8.8 & 9.1\end{array}$

$\begin{array}{lllllllllll}61.0 & 10.1 & 10.2 & 10.4 & 7.1 & 0.0 & 0.0 & 9.9 & 10.1 & 9.8 & 10.1\end{array}$

$\begin{array}{lllllllllll}76.0 & 9.8 & 9.7 & 10.5 & 7.3 & 0.0 & 0.0 & 9.6 & 9.7 & 9.8 & 10.2\end{array}$

$\begin{array}{lllllllllll}91.0 & 9.3 & 9.4 & 9.7 & 7.2 & 0.0 & 0.0 & 9.8 & 9.4 & 9.7 & 10.0\end{array}$

$\begin{array}{lllllllllll}107.0 & 8.1 & 8.9 & 9.6 & 7.3 & 0.0 & 0.0 & 8.9 & 8.5 & 9.4 & 9.4\end{array}$

$\begin{array}{llllllllllll}122.0 & 7.3 & 8.3 & 9.0 & 6.8 & 0.0 & 0.0 & 8.6 & 7.8 & 7.8 & 9.5\end{array}$

$\begin{array}{lllllllllll}137.0 & 7.0 & 7.5 & 7.8 & 6.4 & 0.0 & 0.0 & 7.1 & 6.9 & 7.1 & 9.0\end{array}$

$\begin{array}{lllllllllll}152.0 & 7.0 & 7.8 & 7.5 & 6.9 & 0.0 & 0.0 & 6.7 & 6.8 & 7.3 & 8.0\end{array}$

$\begin{array}{lllllllllll}167.0 & 6.8 & 7.5 & 7.5 & 7.2 & 0.0 & 0.0 & 6.2 & 6.6 & 7.5 & 6.7\end{array}$

$\begin{array}{lllllllllll}183.0 & 6.8 & 7.2 & 7.3 & 6.7 & 0.0 & 0.0 & 6.1 & 6.8 & 7.7 & 7.1\end{array}$

$\begin{array}{lllllllllll}198.0 & 6.3 & 7.4 & 7.5 & 6.8 & 0.0 & 0.0 & 5.9 & 7.8 & 7.7 & 7.1\end{array}$

$\begin{array}{lllllllllll}213.0 & 6.7 & 6.8 & 7.6 & 7.4 & 0.0 & 0.0 & 6.2 & 8.2 & 7.9 & 7.1\end{array}$

$\begin{array}{lllllllllll}229.0 & 6.5 & 7.1 & 7.6 & 7.4 & 0.0 & 0.0 & 6.0 & 7.8 & 7.7 & 6.9\end{array}$

$\begin{array}{lllllllllll}244.0 & 6.8 & 7.6 & 7.4 & 7.5 & 0.0 & 0.0 & 6.6 & 7.9 & 8.3 & 7.3\end{array}$

$\begin{array}{lllllllllll}259.0 & 7.9 & 8.6 & 8.7 & 8.6 & 0.0 & 0.0 & 7.6 & 8.6 & 8.7 & 9.0\end{array}$

$\begin{array}{lllllllllll}274.0 & 9.1 & 9.5 & 9.5 & 8.4 & 0.0 & 0.0 & 8.8 & 10.1 & 9.1 & 9.1\end{array}$

$\begin{array}{lllllllllll}\text { AVG \% } & 7.2 & 7.6 & 7.9 & 6.6 & 0.0 & 0.0 & 7.2 & 7.7 & 7.8 & 7.8\end{array}$ $\begin{array}{lllllllllll}\text { WASTE } \% & 6.7 & 7.3 & 7.5 & 7.1 & 0.0 & 0.0 & 6.2 & 7.4 & 7.7 & 7.2\end{array}$ $\begin{array}{lllllllllll}\text { STRG } \mathrm{cm} & 19.8 & 21.0 & 21.8 & 18.1 & 0.0 & 0.0 & 19.7 & 21.0 & 21.4 & 21.6\end{array}$ 
$\begin{array}{lc}\text { DATE: } & 07-10-84 \\ \text { DAY: } & 192 \\ \text { PROBE: } & 5140\end{array}$

\begin{tabular}{|c|c|c|c|c|c|c|c|c|c|c|}
\hline $\begin{array}{l}\text { DEPTH } \\
\mathrm{cm}\end{array}$ & 1 & 2 & 3 & $\begin{array}{l}\text { VOL W } \\
4\end{array}$ & $\begin{array}{l}\text { ER CO } \\
5\end{array}$ & ENT, & $\frac{1 / m}{7}$ & 8 & 9 & 10 \\
\hline 30.0 & 5.9 & 6.6 & 6.1 & 4.5 & 0.0 & 0.0 & 6.7 & 7.1 & 6.0 & 6.4 \\
\hline 46.0 & 8.8 & 8.6 & 8.8 & 6.5 & 0.0 & 0.0 & 8.6 & 8.9 & 8.2 & 8.8 \\
\hline 61.0 & 10.1 & 10.0 & 10.0 & 7.1 & 0.0 & 0.0 & 9.4 & 9.8 & 9.9 & 9.9 \\
\hline 76.0 & 10.1 & 9.7 & 9.8 & 7.0 & 0.0 & 0.0 & 9.4 & 9.9 & 9.9 & 9.5 \\
\hline 91.0 & 9.5 & 9.4 & 9.6 & 7.2 & 0.0 & 0.0 & 9.4 & 9.7 & 9.9 & 9.8 \\
\hline 107.0 & 8.6 & 9.3 & 9.3 & 7.2 & 0.0 & 0.0 & 9.3 & 9.2 & 9.3 & 9.6 \\
\hline 122.0 & 7.6 & 9.1 & 8.8 & 7.1 & 0.0 & 0.0 & 8.6 & 8.3 & 8.3 & 9.5 \\
\hline 137.0 & 7.6 & 8.1 & 8.1 & 6.8 & 0.0 & 0.0 & 7.5 & 7.4 & 7.3 & 9.1 \\
\hline 152.0 & 7.2 & 7.8 & 7.0 & 7.4 & 0.0 & 0.0 & 6.6 & 7.2 & 7.7 & 8.7 \\
\hline 167.0 & 7.1 & 7.9 & 7.2 & 7.9 & 0.0 & 0.0 & 6.8 & 7.0 & 7.3 & 7.7 \\
\hline 183.0 & 6.8 & 7.6 & 7.8 & 7.2 & 0.0 & 0.0 & 6.6 & 6.5 & 7.5 & 7.2 \\
\hline 198.0 & 6.9 & 7.5 & 7.7 & 7.5 & 0.0 & 0.0 & 6.3 & 7.8 & 7.8 & 7.4 \\
\hline 213.0 & 6.7 & 7.3 & 7.4 & 7.9 & 0.0 & 0.0 & 6.1 & 7.8 & 8.4 & 7.0 \\
\hline 229.0 & 6.6 & 7.0 & 7.2 & 7.8 & 0.0 & 0.0 & 6.4 & 7.3 & 7.5 & 7.0 \\
\hline 244.0 & 7.2 & 7.7 & 7.1 & 7.7 & 0.0 & 0.0 & 6.6 & 7.9 & 8.5 & 7.4 \\
\hline 259.0 & 8.0 & 8.3 & 8.5 & 8.7 & 0.0 & 0.0 & 7.8 & 8.6 & 8.8 & 9.2 \\
\hline 274.0 & 9.3 & 9.4 & 9.5 & 9.3 & 0.0 & 0.0 & 9.0 & 10.8 & 9.0 & 9.2 \\
\hline
\end{tabular}

$\begin{array}{lllllllllll}\text { AVG } \% & 7.3 & 7.8 & 7.7 & 6.8 & 0.0 & 0.0 & 7.2 & 7.7 & 7.8 & 7.9\end{array}$ $\begin{array}{lllllllllll}\text { WASTE \% } & 6.9 & 7.6 & 7.4 & 7.6 & 0.0 & 0.0 & 6.5 & 7.4 & 7.8 & 7.5\end{array}$ $\begin{array}{lllllllllll}\text { STRG Cm } & 20.2 & 21.4 & 21.1 & 18.6 & 0.0 & 0.0 & 19.8 & 21.1 & 21.4 & 21.7\end{array}$ 
DATE: $\quad 07-27-84$

PROBE: 5140 STANDARD COUNTS: 11171

\begin{tabular}{|c|c|c|c|c|c|c|c|c|c|c|}
\hline $\begin{array}{l}\text { DEPTH } \\
\mathrm{cm}\end{array}$ & 1 & 2 & 3 & $\begin{array}{l}\text { VOL } \\
4\end{array}$ & $\begin{array}{c}\text { ER CO } \\
5\end{array}$ & $\begin{array}{c}\text { ENT, } \\
6\end{array}$ & $\begin{array}{c}\mathrm{cm} / \mathrm{m} \\
7\end{array}$ & 8 & 9 & 10 \\
\hline 30.0 & 5.4 & 5.3 & 5.6 & 3.3 & 0.0 & 0.0 & 5.7 & 6.0 & 5.0 & 4.4 \\
\hline 46.0 & 8.1 & 8.5 & 8.3 & 5.9 & 0.0 & 0.0 & 7.9 & 8.2 & 7.3 & 6.9 \\
\hline 61.0 & 9.9 & 9.2 & 9.5 & 7.2 & 0.0 & 0.0 & 8.9 & 9.3 & 8.6 & 8.8 \\
\hline 76.0 & 9.8 & 9.3 & 9.7 & 6.8 & 0.0 & 0.0 & 9.6 & 9.4 & 9.1 & 9.1 \\
\hline 91.0 & 9.0 & 9.2 & 9.6 & 7.3 & 0.0 & 0.0 & 9.3 & 9.1 & 9.0 & 8.7 \\
\hline 107.0 & 8.4 & 9.1 & 9.5 & 7.0 & 0.0 & 0.0 & 9.2 & 8.4 & 8.8 & 8.6 \\
\hline 122.0 & 8.1 & 8.4 & 9.3 & 7.0 & 0.0 & 0.0 & 8.8 & 8.0 & 8.4 & 8.9 \\
\hline 137.0 & 7.4 & 8.3 & 8.4 & 6.7 & 0.0 & 0.0 & 8.3 & 7.7 & 7.3 & 8.9 \\
\hline 152.0 & 7.6 & 7.8 & 7.5 & 7.7 & 0.0 & 0.0 & 7.5 & 7.1 & 7.5 & 9.1 \\
\hline 167.0 & 6.9 & 7.0 & 7.6 & 8.0 & 0.0 & 0.0 & 6.8 & 7.1 & 7.5 & 8.4 \\
\hline 183.0 & 6.7 & 7.1 & 7.5 & 7.4 & 0.0 & 0.0 & 6.4 & 6.7 & 7.4 & 7.3 \\
\hline 198.0 & 6.6 & 7.7 & 7.4 & 7.4 & 0.0 & 0.0 & 6.4 & 7.9 & 7.9 & 7.3 \\
\hline 213.0 & 6.6 & 7.2 & 7.7 & 7.3 & 0.0 & 0.0 & 6.4 & 7.7 & 8.0 & 7.5 \\
\hline 229.0 & 6.3 & 6.7 & 7.3 & 7.5 & 0.0 & 0.0 & 5.9 & 7.7 & 8.2 & 6.8 \\
\hline 244.0 & 6.5 & 7.5 & 7.5 & 7.8 & 0.0 & 0.0 & 6.3 & 8.1 & 8.1 & 7.4 \\
\hline 259.0 & 8.3 & 8.7 & 8.7 & 8.5 & 0.0 & 0.0 & 7.7 & 8.8 & 8.8 & 8.4 \\
\hline 274.0 & 9.5 & 9.3 & 10.0 & 8.8 & 0.0 & 0.0 & 9.4 & 10.3 & 8.3 & 9.2 \\
\hline AVG \% & 7.2 & 7.5 & 7.7 & 6.6 & 0.0 & 0.0 & 7.1 & 7.5 & 7.5 & 7.4 \\
\hline WASTE $\%$ & 6.7 & 7.3 & 7.5 & 7.6 & 0.0 & 0.0 & 6.5 & 7.5 & 7.8 & 7.7 \\
\hline TRG $\mathrm{cm}$ & 9.7 & 20.5 & 21.2 & 18.2 & 0.0 & 0.0 & 19.6 & 20.6 & 20.5 & 20.4 \\
\hline
\end{tabular}




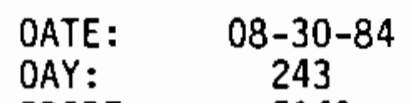

PROBE : $\quad 5140 \quad$ STANOARD COUNTS: 11297

\begin{tabular}{|c|c|c|c|c|c|c|c|c|c|c|}
\hline $\begin{array}{l}\text { OEPTH } \\
\mathrm{cm}\end{array}$ & 1 & 2 & 3 & $\begin{array}{l}\text { VOL } \\
4\end{array}$ & $\begin{array}{c}\text { ER } \\
5\end{array}$ & $\begin{array}{l}\text { ENT } \\
6\end{array}$ & $\begin{array}{l}1 / m \\
7\end{array}$ & 8 & 9 & 10 \\
\hline 30.0 & 4.4 & 4.3 & 4.5 & 2.1 & 0.0 & 0.0 & 4.9 & 4.7 & 4.0 & 3.7 \\
\hline 46.0 & 6.7 & 7.0 & 7.3 & 4.1 & 0.0 & 0.0 & 6.7 & 6.9 & 6.2 & 6.6 \\
\hline 61.0 & 8.1 & 7.7 & 8.6 & 5.0 & 0.0 & 0.0 & 7.8 & 8.1 & 7.8 & 7.7 \\
\hline 76.0 & 8.8 & 7.8 & 9.1 & 5.7 & 0.0 & 0.0 & 8.3 & 8.2 & 8.3 & 7.8 \\
\hline 91.0 & 8.1 & 7.9 & 9.2 & 5.7 & 0.0 & 0.0 & 8.9 & 8.4 & 8.5 & 7.8 \\
\hline 107.0 & 8.4 & 8.4 & 9.3 & 5.8 & 0.0 & 0.0 & 8.7 & 8.5 & 8.1 & 7.6 \\
\hline 122.0 & 7.8 & 8.5 & 9.4 & 5.8 & 0.0 & 0.0 & 8.7 & 7.4 & 7.9 & 8.0 \\
\hline 137.0 & 7.5 & 8.4 & 8.6 & 6.4 & 0.0 & 0.0 & 8.2 & 7.3 & 7.6 & 7.9 \\
\hline 152.0 & 7.6 & 7.7 & 8.3 & 7.2 & 0.0 & 0.0 & 7.5 & 6.3 & 7.2 & 8.1 \\
\hline 167.0 & 6.8 & 7.3 & 7.8 & 7.6 & 0.0 & 0.0 & 6.9 & 6.1 & 6.9 & 8.2 \\
\hline 183.0 & 7.1 & 7.2 & 7.3 & 7.4 & 0.0 & 0.0 & 6.5 & 6.0 & 7.0 & 7.1 \\
\hline 198.0 & 6.6 & 7.1 & 7.5 & 7.0 & 0.0 & 0.0 & 6.4 & 6.9 & 7.6 & 7.2 \\
\hline 213.0 & 6.6 & 7.1 & 7.7 & 7.1 & 0.0 & 0.0 & 6.3 & 7.0 & 8.0 & 7.1 \\
\hline 229.0 & 6.3 & 7.1 & 7.1 & 7.3 & 0.0 & 0.0 & 6.1 & 7.3 & 7.4 & 6.0 \\
\hline 244.0 & 6.7 & 7.5 & 7.0 & 7.5 & 0.0 & 0.0 & 6.4 & 7.5 & 7.6 & 6.7 \\
\hline 259.0 & 8.2 & 8.5 & 8.5 & 8.3 & 0.0 & 0.0 & 7.5 & 8.2 & 8.7 & 8.8 \\
\hline 274.0 & 9.2 & 9.3 & 9.5 & 8.1 & 0.0 & 0.0 & 8.8 & 9.5 & 8.8 & 9.1 \\
\hline
\end{tabular}

$\begin{array}{lllllllllll}\text { AVG } \% & 6.8 & 7.0 & 7.5 & 5.9 & 0.0 & 0.0 & 6.8 & 6.7 & 7.0 & 6.8\end{array}$

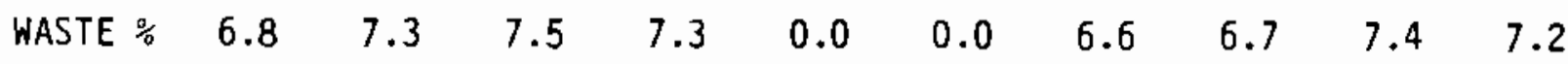

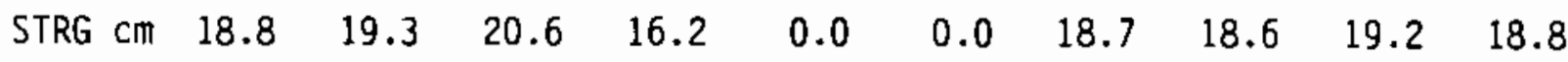


DATE: $\quad 09-25-84$

$\begin{array}{ll}\text { DAY: } & 269 \\ \text { PROBE: } & 5140\end{array}$

STANDARD COUNTS: 11253

\begin{tabular}{|c|c|c|c|c|c|c|c|c|c|c|}
\hline $\begin{array}{l}\text { DEPTH } \\
\text { cm }\end{array}$ & 1 & 2 & 3 & $\begin{array}{l}6 \text { VOL } \\
4\end{array}$ & $\begin{array}{c}\text { WATER C } \\
5\end{array}$ & $\begin{array}{c}\text { CONTENT, } \\
6\end{array}$ & $\mathrm{~cm} / \mathrm{m}$ & 8 & 9 & 10 \\
\hline 30.0 & 5.0 & 5.3 & 5.4 & 4.7 & 2.1 & 2.7 & 6.4 & 5.4 & 5.1 & 5.5 \\
\hline 46.0 & 6.3 & 7.2 & 6.7 & 6.5 & 2.6 & 2.8 & 7.4 & 6.6 & 6.1 & 6.4 \\
\hline 61.0 & 7.7 & 7.5 & 8.0 & 7.7 & 2.8 & 3.0 & 8.4 & 7.6 & 7.0 & 7.2 \\
\hline 76.0 & 8.3 & 7.6 & 8.9 & 8.0 & 2.8 & 2.5 & 8.6 & 7.9 & 7.9 & 7.0 \\
\hline 91.0 & 8.4 & 7.8 & 8.4 & 8.0 & 3.8 & 2.4 & 9.2 & 8.3 & 8.3 & 7.3 \\
\hline 107.0 & 8.0 & 8.3 & 8.7 & 8.6 & 3.6 & 3.0 & 9.1 & 7.9 & 8.2 & 7.8 \\
\hline 122.0 & 7.8 & 8.2 & 9.3 & 8.8 & 3.1 & 2.5 & 8.6 & 8.0 & 7.9 & 7.6 \\
\hline 137.0 & 7.6 & 7.8 & 8.3 & 8.5 & 3.1 & 2.5 & 8.2 & 7.8 & 7.8 & 7.7 \\
\hline 152.0 & 7.3 & 8.2 & 8.0 & 8.3 & 3.2 & 3.7 & 7.2 & 6.9 & 8.0 & 8.1 \\
\hline 167.0 & 6.9 & 7.7 & 7.8 & 9.4 & 4.3 & 5.2 & 8.0 & 6.7 & 7.5 & 7.8 \\
\hline 183.0 & 6.7 & 7.2 & 7.1 & 8.8 & 5.3 & 5.4 & 6.9 & 6.7 & 7.4 & 6.8 \\
\hline 198.0 & 6.4 & 7.0 & 7.2 & 8.0 & 6.2 & 6.5 & 6.6 & 7.1 & 7.7 & 6.9 \\
\hline 213.0 & 6.5 & 7.0 & 7.5 & 7.6 & 6.9 & 7.2 & 6.5 & 7.3 & 8.2 & 6.9 \\
\hline 229.0 & 6.4 & 7.0 & 6.9 & 7.3 & 7.1 & 7.7 & 6.3 & 7.3 & 7.4 & 6.7 \\
\hline 244.0 & 6.5 & 7.7 & 7.2 & 7.5 & 7.0 & 8.4 & 6.9 & 7.6 & 7.7 & 7.3 \\
\hline 259.0 & 7.4 & 8.3 & 8.4 & 8.8 & 7.3 & 9.1 & 7.7 & 8.6 & 8.6 & 8.7 \\
\hline 274.0 & 8.4 & 9.3 & 9.0 & 9.4 & 8.5 & 10.8 & 9.3 & 10.2 & 8.6 & 9.2 \\
\hline
\end{tabular}

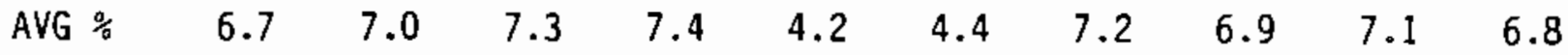
$\begin{array}{lllllllllll}\text { WASTE \% } & 6.7 & 7.4 & 7.4 & 8.1 & 5.7 & 6.3 & 6.9 & 7.1 & 7.7 & 7.2\end{array}$ $\begin{array}{lllllllllll}\text { STRG } \mathrm{cm} & 18.3 & 19.4 & 20.0 & 20.5 & 11.5 & 12.1 & 19.7 & 19.0 & 19.6 & 18.7\end{array}$ 
DATE: $\quad 11-09-84$

DAY: $\quad 314$

PROBE: $\quad 5140 \quad$ STANDARD COUNTS: 11293

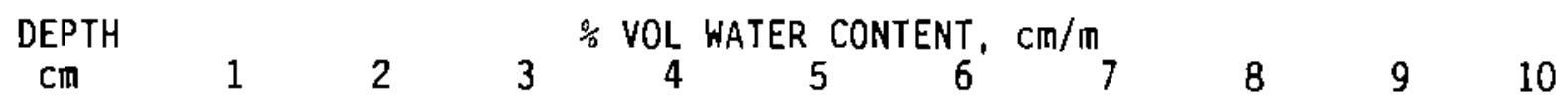

$\begin{array}{lllllllllll}30.0 & 5.1 & 5.2 & 5.6 & 4.6 & 1.9 & 2.0 & 5.0 & 5.3 & 5.1 & 4.8\end{array}$

$\begin{array}{lllllllllll}46.0 & 6.5 & 6.4 & 6.9 & 5.9 & 3.0 & 2.0 & 6.4 & 6.1 & 6.5 & 6.8\end{array}$

$\begin{array}{lllllllllll}61.0 & 7.6 & 7.0 & 7.6 & 7.0 & 2.6 & 2.8 & 6.7 & 6.5 & 7.5 & 7.1\end{array}$

$\begin{array}{lllllllllll}76.0 & 7.6 & 6.9 & 7.9 & 7.4 & 2.5 & 2.6 & 7.3 & 6.9 & 8.0 & 7.2\end{array}$

$\begin{array}{lllllllllll}91.0 & 7.7 & 7.4 & 8.1 & 7.9 & 3.3 & 2.9 & 8.2 & 7.6 & 7.6 & 6.4\end{array}$

$\begin{array}{lllllllllll}107.0 & 7.5 & 7.2 & 8.3 & 8.3 & 3.5 & 2.8 & 7.8 & 7.7 & 8.1 & 7.3\end{array}$

$\begin{array}{lllllllllll}122.0 & 7.7 & 7.5 & 9.2 & 8.3 & 3.5 & 3.1 & 8.7 & 8.2 & 7.9 & 7.3\end{array}$

$\begin{array}{lllllllllll}137.0 & 7.6 & 7.8 & 8.7 & 8.4 & 2.9 & 3.2 & 8.2 & 7.7 & 7.8 & 7.2\end{array}$

$\begin{array}{lllllllllll}152.0 & 7.5 & 7.8 & 8.5 & 8.4 & 3.6 & 3.5 & 8.1 & 7.1 & 7.4 & 7.8\end{array}$

$\begin{array}{lllllllllll}167.0 & 7.8 & 7.5 & 8.2 & 8.8 & 4.2 & 4.7 & 7.6 & 6.7 & 8.2 & 7.5\end{array}$

$\begin{array}{lllllllllll}183.0 & 6.8 & 7.5 & 8.0 & 8.3 & 5.2 & 5.4 & 6.1 & 6.9 & 8.0 & 7.2\end{array}$

$\begin{array}{lllllllllll}198.0 & 6.6 & 7.0 & 7.3 & 8.2 & 6.2 & 6.3 & 6.1 & 7.1 & 7.6 & 6.8\end{array}$

$\begin{array}{lllllllllll}213.0 & 6.5 & 6.7 & 7.4 & 7.8 & 6.3 & 7.1 & 5.6 & 7.1 & 7.7 & 6.2\end{array}$

$\begin{array}{lllllllllll}229.0 & 6.2 & 6.7 & 7.0 & 7.3 & 6.5 & 7.4 & 6.3 & 7.6 & 7.1 & 6.2\end{array}$

$\begin{array}{lllllllllll}244.0 & 6.5 & 7.7 & 7.7 & 7.3 & 6.8 & 8.1 & 5.5 & 8.1 & 8.1 & 7.0\end{array}$

$\begin{array}{lllllllllll}259.0 & 7.2 & 8.5 & 8.3 & 8.7 & 7.3 & 9.1 & 6.6 & 8.0 & 8.4 & 8.6\end{array}$

$\begin{array}{lllllllllll}274.0 & 8.4 & 9.6 & 9.9 & 8.5 & 8.1 & 11.3 & 8.2 & 10.6 & 8.5 & 9.2\end{array}$

$\begin{array}{lllllllllll}\text { AVG \% } & 6.6 & 6.7 & 7.3 & 7.2 & 4.1 & 4.3 & 6.5 & 6.7 & 7.1 & 66\end{array}$ $\begin{array}{lllllllllll}\text { WASTE \% } & 6.9 & 7.3 & 7.7 & 8.0 & 5.5 & 6.1 & 6.5 & 7.2 & 7.7 & 7.0\end{array}$ $\begin{array}{lllllllllll}\text { STRG Cm } & 18.2 & 18.6 & 20.2 & 19.9 & 11.2 & 11.8 & 17.8 & 18.6 & 19.6 & 18.0\end{array}$ 
DATE: $\quad 12-13-84$

DAY: $\quad 348$

PROBE: $\quad 5140 \quad$ STANDARD COUNTS: 12175

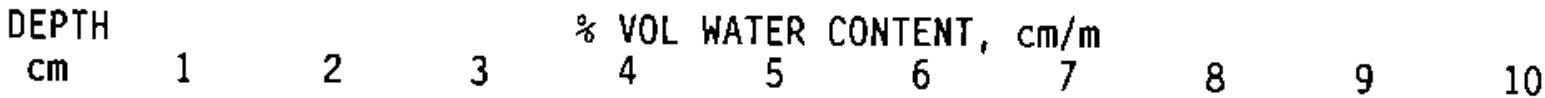

$\begin{array}{lllllllllll}30.0 & 9.4 & 9.7 & 9.8 & 9.0 & 8.9 & 9.3 & 9.2 & 9.7 & 9.3 & 9.4\end{array}$ $\begin{array}{lllllllllll}46.0 & 9.9 & 10.9 & 10.5 & 9.5 & 9.3 & 8.0 & 10.0 & 10.2 & 10.4 & 10.8\end{array}$ $\begin{array}{lllllllllll}61.0 & 10.8 & 10.7 & 10.4 & 9.4 & 7.4 & 5.0 & 9.9 & 10.1 & 10.4 & 10.7\end{array}$ $\begin{array}{lllllllllll}76.0 & 10.7 & 10.1 & 10.7 & 9.0 & 4.2 & 3.5 & 10.0 & 10.0 & 10.6 & 10.4\end{array}$ $\begin{array}{lllllllllll}91.0 & 9.7 & 9.7 & 10.2 & 8.3 & 3.6 & 2.8 & 9.3 & 10.2 & 10.1 & 9.9\end{array}$ $\begin{array}{lllllllllll}107.0 & 8.6 & 8.9 & 10.1 & 8.5 & 4.0 & 3.1 & 9.0 & 9.2 & 9.8 & 9.5\end{array}$ $\begin{array}{lllllllllll}122.0 & 7.4 & 8.3 & 9.6 & 7.8 & 3.5 & 3.3 & 8.4 & 8.1 & 8.9 & 8.5\end{array}$ $\begin{array}{lllllllllll}137.0 & 7.5 & 8.3 & 8.6 & 7.7 & 3.3 & 3.5 & 8.4 & 7.3 & 8.4 & 7.5\end{array}$ $\begin{array}{lllllllllll}152.0 & 7.8 & 8.7 & 8.9 & 7.6 & 4.0 & 4.7 & 8.2 & 7.1 & 8.6 & 7.9\end{array}$ $\begin{array}{lllllllllll}167.0 & 7.9 & 8.5 & 8.7 & 8.2 & 5.0 & 5.3 & 7.8 & 6.0 & 7.9 & 7.4\end{array}$ $\begin{array}{lllllllllll}183.0 & 7.4 & 7.6 & 7.4 & 8.0 & 5.6 & 5.5 & 6.7 & 6.1 & 7.4 & 6.9\end{array}$ $\begin{array}{lllllllllll}198.0 & 6.4 & 7.6 & 7.4 & 7.3 & 6.3 & 6.0 & 6.1 & 6.7 & 8.0 & 7.1\end{array}$ $\begin{array}{lllllllllll}213.0 & 6.5 & 7.4 & 6.9 & 7.2 & 6.2 & 6.7 & 6.3 & 6.8 & 7.7 & 6.8\end{array}$ $\begin{array}{lllllllllll}229.0 & 5.9 & 7.3 & 7.2 & 6.6 & 6.4 & 7.0 & 6.4 & 6.7 & 7.2 & 6.3\end{array}$ $\begin{array}{lllllllllll}244.0 & 6.6 & 6.9 & 7.0 & 7.2 & 6.9 & 7.1 & 6.0 & 7.4 & 8.0 & 6.8\end{array}$ $\begin{array}{lllllllllll}259.0 & 7.0 & 8.7 & 7.7 & 8.0 & 7.2 & 8.2 & 6.8 & 7.7 & 8.2 & 8.4\end{array}$ $\begin{array}{lllllllllll}274.0 & 8.3 & 9.8 & 9.1 & 8.3 & 8.2 & 9.7 & 8.3 & 9.2 & 8.0 & 8.8\end{array}$

$\begin{array}{lllllllllll}\text { AVG } \% & 7.6 & 8.2 & 8.3 & 7.6 & 5.4 & 5.2 & 7.6 & 7.6 & 8.3 & 79\end{array}$ $\begin{array}{lllllllllll}\text { WASTE \% } & 6.9 & 7.7 & 7.6 & 7.5 & 5.8 & 6.0 & 6.8 & 6.7 & 7.8 & 7.0\end{array}$ $\begin{array}{lllllllllll}\text { STRG } \mathrm{Cm} & 21.0 & 22.5 & 22.8 & 20.9 & 14.9 & 14.4 & 20.8 & 20.9 & 22.8 & 21.7\end{array}$ 
DATE: $\quad 02-04-85$

DAY: $\quad 401$

PROBE: $\quad 5140 \quad$ STANDARD COUNTS: 22628

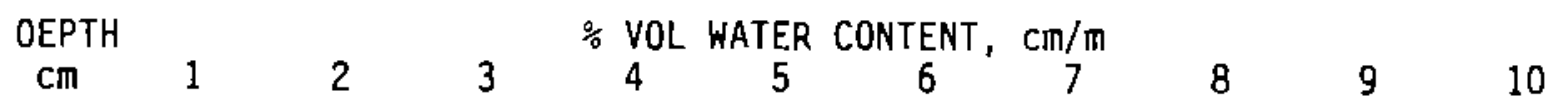

$\begin{array}{lllllllllll}30.0 & 9.4 & 9.8 & 10.5 & 9.4 & 8.7 & 9.7 & 10.5 & 10.6 & 9.8 & 9.7\end{array}$ $\begin{array}{lllllllllll}46.0 & 10.2 & 11.0 & 10.8 & 9.7 & 9.5 & 9.3 & 9.8 & 11.0 & 10.7 & 10.6\end{array}$ $\begin{array}{lllllllllll}61.0 & 10.6 & 10.3 & 10.2 & 9.7 & 8.5 & 7.2 & 10.0 & 10.1 & 9.9 & 9.8\end{array}$ $\begin{array}{lllllllllll}76.0 & 10.3 & 10.3 & 10.8 & 9.7 & 6.9 & 5.3 & 10.4 & 10.0 & 10.1 & 9.8\end{array}$ $\begin{array}{lllllllllll}91.0 & 9.8 & 9.9 & 10.7 & 9.8 & 5.2 & 3.4 & 10.6 & 10.8 & 10.5 & 9.6\end{array}$ $\begin{array}{lllllllllll}107.0 & 9.8 & 9.8 & 11.1 & 9.7 & 4.0 & 3.1 & 10.7 & 10.2 & 10.4 & 9.9\end{array}$ $\begin{array}{lllllllllll}122.0 & 9.3 & 9.5 & 10.6 & 9.1 & 3.1 & 3.4 & 11.0 & 9.6 & 10.4 & 9.7\end{array}$ $\begin{array}{lllllllllll}137.0 & 9.2 & 9.6 & 10.3 & 8.9 & 3.6 & 4.1 & 10.4 & 9.0 & 9.5 & 10.1\end{array}$ $\begin{array}{lllllllllll}152.0 & 8.2 & 9.1 & 9.4 & 8.5 & 4.6 & 5.4 & 10.0 & 8.6 & 9.8 & 10.0\end{array}$ $\begin{array}{lllllllllll}167.0 & 8.9 & 8.4 & 9.6 & 8.7 & 5.0 & 5.8 & 10.4 & 8.2 & 9.4 & 9.9\end{array}$ $\begin{array}{lllllllllll}183.0 & 7.5 & 8.1 & 8.2 & 8.5 & 6.1 & 5.9 & 10.0 & 7.0 & 9.1 & 9.3\end{array}$ $\begin{array}{lllllllllll}198.0 & 7.1 & 8.1 & 8.4 & 8.2 & 6.5 & 6.8 & 9.3 & 7.0 & 8.8 & 8.7\end{array}$ $\begin{array}{lllllllllll}213.0 & 7.2 & 7.8 & 7.7 & 7.8 & 6.8 & 7.4 & 8.7 & 7.5 & 8.3 & 7.2\end{array}$ $\begin{array}{lllllllllll}229.0 & 6.3 & 7.5 & 7.5 & 7.2 & 6.6 & 7.3 & 7.0 & 7.2 & 7.8 & 5.6\end{array}$ $\begin{array}{lllllllllll}244.0 & 6.5 & 7.7 & 7.1 & 7.5 & 7.3 & 8.2 & 6.8 & 7.7 & 8.3 & 6.5\end{array}$ $\begin{array}{lllllllllll}259.0 & 8.0 & 8.8 & 8.1 & 8.4 & 7.3 & 8.8 & 7.9 & 8.2 & 8.8 & 7.8\end{array}$ $\begin{array}{lllllllllll}274.0 & 9.1 & 9.6 & 9.1 & 8.5 & 8.2 & 10.8 & 8.7 & 9.4 & 8.6 & 8.3\end{array}$

$\begin{array}{lllllllllll}\text { AVG \% } & 8.1 & 8.6 & 8.9 & 8.3 & 5.9 & 5.9 & 9.0 & 8.4 & 8.9 & 8.5\end{array}$ $\begin{array}{lllllllllll}\text { WASTE \% } & 7.4 & 8.1 & 8.3 & 8.1 & 6.1 & 6.7 & 8.9 & 7.6 & 8.8 & 8.2\end{array}$ $\begin{array}{lllllllllll}\text { STRG } \mathrm{cm} & 22.4 & 23.6 & 24.4 & 22.8 & 16.2 & 16.3 & 24.9 & 23.1 & 24.5 & 23.3\end{array}$ 
DATE: $\quad 02-12-85$

PROBE: $\quad 2499$ STANDARD COUNTS: 34529

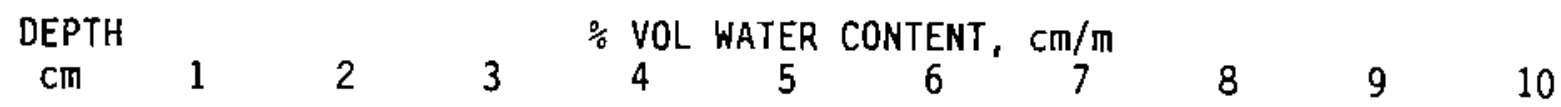

$\begin{array}{lllllllllll}30.0 & 16.2 & 16.3 & 16.8 & 15.5 & 17.2 & 17.1 & 15.3 & 15.4 & 16.3 & 26.8\end{array}$ $\begin{array}{lllllllllll}46.0 & 16.8 & 16.9 & 16.2 & 15.0 & 17.1 & 16.7 & 14.2 & 15.0 & 15.6 & 25.2\end{array}$ $\begin{array}{lllllllllll}61.0 & 16.1 & 15.7 & 15.2 & 14.7 & 11.4 & 10.7 & 14.4 & 13.7 & 14.2 & 20.5\end{array}$ $\begin{array}{lllllllllll}76.0 & 15.4 & 15.4 & 15.0 & 14.1 & 7.4 & 6.4 & 14.7 & 13.4 & 14.0 & 14.0\end{array}$ $\begin{array}{lllllllllll}91.0 & 13.9 & 14.8 & 14.9 & 13.4 & 5.4 & 4.2 & 14.9 & 13.9 & 14.0 & 13.8\end{array}$ $\begin{array}{lllllllllll}107.0 & 12.9 & 13.8 & 15.2 & 13.0 & 4.4 & 3.2 & 14.9 & 14.0 & 14.1 & 14.3\end{array}$ $\begin{array}{lllllllllll}122.0 & 11.1 & 11.6 & 14.5 & 10.9 & 4.4 & 3.5 & 15.1 & 13.9 & 13.8 & 14.4\end{array}$ $\begin{array}{lllllllllll}137.0 & 10.5 & 10.4 & 12.8 & 9.2 & 4.3 & 3.8 & 15.0 & 13.9 & 13.6 & 14.4\end{array}$ $\begin{array}{llllllllllll}152.0 & 9.8 & 10.5 & 11.5 & 9.3 & 4.9 & 5.1 & 14.9 & 14.5 & 14.4 & 15.0\end{array}$ $\begin{array}{lllllllllll}167.0 & 9.6 & 9.8 & 10.1 & 10.1 & 6.0 & 6.0 & 13.2 & 14.3 & 15.5 & 14.8\end{array}$ $\begin{array}{lllllllllll}183.0 & 9.1 & 9.0 & 9.4 & 9.2 & 6.7 & 6.3 & 11.0 & 14.9 & 16.2 & 14.5\end{array}$ $\begin{array}{llllllllllll}198.0 & 8.7 & 9.2 & 9.0 & 8.7 & 7.2 & 7.1 & 11.1 & 16.2 & 17.0 & 15.9\end{array}$ $\begin{array}{lllllllllll}213.0 & 8.2 & 8.6 & 8.6 & 9.1 & 7.9 & 7.7 & 10.2 & 16.7 & 16.8 & 17.3\end{array}$ $\begin{array}{lllllllllll}229.0 & 7.9 & 8.4 & 8.3 & 8.5 & 7.6 & 7.6 & 9.2 & 16.1 & 17.0 & 30.1\end{array}$ $\begin{array}{lllllllllll}244.0 & 7.8 & 8.7 & 8.2 & 8.3 & 7.2 & 8.1 & 7.8 & 18.2 & 16.9 & 44.0\end{array}$ $\begin{array}{lllllllllll}259.0 & 9.0 & 9.2 & 8.3 & 9.1 & 7.8 & 9.0 & 8.4 & 28.4 & 20.0 & 44.0\end{array}$ $\begin{array}{lllllllllll}274.0 & 10.1 & 10.2 & 9.5 & 9.4 & 8.0 & 11.1 & 8.8 & 44.0 & 44.0 & 44.0\end{array}$

$\begin{array}{lllllllllll}\text { AVG } \% & 10.8 & 11.1 & 11.4 & 10.5 & 7.5 & 7.2 & 12.0 & 14.9 & 14.7 & 19.9\end{array}$ $\begin{array}{lllllllllll}\text { WASTE \% } & 8.7 & 9.2 & 9.3 & 9.0 & 6.8 & 6.8 & 11.1 & 15.9 & 16.3 & 21.6\end{array}$ $\begin{array}{lllllllllll}\text { STRG cm } & 29.6 & 30.5 & 31.4 & 28.8 & 20.5 & 19.8 & 33.0 & 40.9 & 40.3 & 54.8\end{array}$ 
DATE: $\quad 02-27-85$

DAY: $\quad 424$

PROBE: $\quad 2499$ STANDARD COUNTS: 17234

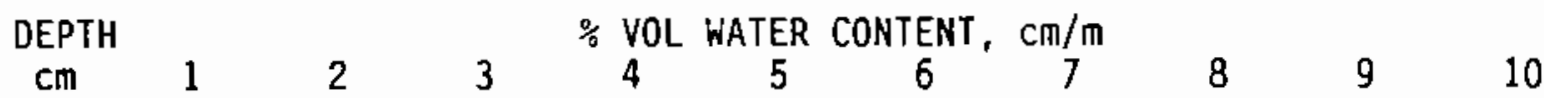

$\begin{array}{lllllllllll}30.0 & 8.2 & 8.8 & 8.8 & 9.2 & 10.1 & 9.9 & 9.6 & 9.5 & 7.9 & 8.7\end{array}$ $\begin{array}{lllllllllll}46.0 & 10.7 & 11.2 & 10.6 & 10.6 & 12.0 & 11.8 & 10.2 & 10.4 & 10.7 & 10.7\end{array}$ $\begin{array}{lllllllllll}61.0 & 12.2 & 12.0 & 12.4 & 10.8 & 14.4 & 12.5 & 11.3 & 10.8 & 11.2 & 11.1\end{array}$ $\begin{array}{lllllllllll}76.0 & 12.2 & 12.0 & 12.4 & 11.7 & 13.2 & 12.7 & 12.1 & 11.8 & 10.9 & 11.2\end{array}$ $\begin{array}{lllllllllll}91.0 & 11.4 & 12.4 & 12.6 & 11.8 & 13.8 & 11.7 & 11.9 & 11.7 & 10.8 & 11.6\end{array}$ $\begin{array}{lllllllllll}107.0 & 11.5 & 13.2 & 12.8 & 11.7 & 13.3 & 8.8 & 11.8 & 11.2 & 11.8 & 11.6\end{array}$ $\begin{array}{lllllllllll}122.0 & 11.2 & 13.0 & 12.2 & 12.3 & 10.1 & 5.6 & 11.5 & 11.3 & 12.0 & 11.2\end{array}$ $\begin{array}{lllllllllll}137.0 & 11.5 & 12.6 & 12.5 & 12.2 & 6.4 & 4.5 & 12.5 & 10.7 & 11.6 & 11.9\end{array}$ $\begin{array}{lllllllllll}152.0 & 11.5 & 13.2 & 12.2 & 12.2 & 5.6 & 5.6 & 12.5 & 11.5 & 12.0 & 11.4\end{array}$ $\begin{array}{lllllllllll}167.0 & 11.2 & 13.6 & 13.2 & 12.2 & 5.8 & 5.9 & 12.7 & 11.4 & 13.1 & 11.4\end{array}$ $\begin{array}{lllllllllll}183.0 & 10.6 & 13.2 & 12.1 & 12.7 & 6.0 & 6.3 & 12.6 & 12.8 & 13.7 & 11.7\end{array}$ $\begin{array}{lllllllllll}198.0 & 11.6 & 13.2 & 12.3 & 13.3 & 7.2 & 7.5 & 13.0 & 12.8 & 14.6 & 11.9\end{array}$ $\begin{array}{lllllllllll}213.0 & 12.0 & 13.4 & 12.0 & 13.2 & 7.3 & 8.1 & 13.4 & 13.0 & 14.3 & 12.3\end{array}$ $\begin{array}{lllllllllll}229.0 & 11.3 & 12.5 & 11.8 & 12.7 & 7.7 & 7.7 & 13.2 & 12.6 & 13.9 & 12.0\end{array}$ $\begin{array}{lllllllllll}244.0 & 11.1 & 13.0 & 11.8 & 12.5 & 7.9 & 7.8 & 12.7 & 13.4 & 14.0 & 14.3\end{array}$ $\begin{array}{lllllllllll}259.0 & 12.3 & 13.1 & 11.9 & 12.1 & 8.2 & 9.2 & 13.3 & 14.9 & 15.5 & 24.2\end{array}$ $\begin{array}{lllllllllll}274.0 & 12.4 & 13.4 & 11.9 & 10.6 & 9.2 & 10.8 & 14.0 & 28.1 & 23.9 & 44.0\end{array}$

$\begin{array}{lllllllllll}\text { AVG \% } & 10.6 & 11.8 & 11.3 & 11.2 & 8.8 & 8.0 & 11.4 & 11.2 & 11.7 & 11.6\end{array}$ $\begin{array}{lllllllllll}\text { WASTE 号 } & 11.3 & 13.2 & 12.2 & 12.7 & 6.8 & 7.0 & 12.9 & 12.5 & 13.7 & 12.1\end{array}$ $\begin{array}{lllllllllll}\text { STRG CM } & 29.2 & 32.4 & 31.0 & 30.9 & 24.1 & 21.9 & 31.4 & 30.7 & 32.0 & 31.9\end{array}$ 
DATE: $\quad 03-12-85$

DAY: $\quad 437$

PROBE: $\quad 5140 \quad$ STANDARD COUNTS: 11947

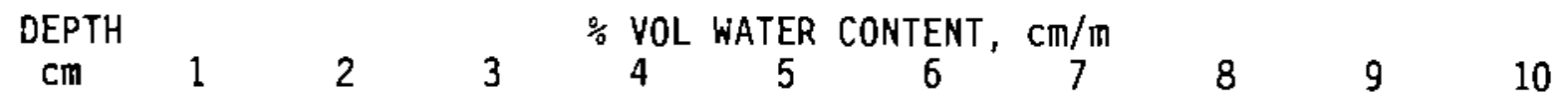

$\begin{array}{lllllllllll}30.0 & 8.7 & 8.2 & 8.7 & 8.9 & 9.3 & 9.3 & 8.8 & 8.9 & 7.8 & 8.7\end{array}$ $\begin{array}{lllllllllll}46.0 & 10.2 & 10.6 & 10.4 & 9.9 & 10.6 & 10.3 & 10.1 & 10.3 & 10.1 & 10.4\end{array}$ $\begin{array}{lllllllllll}61.0 & 11.2 & 10.9 & 10.8 & 10.4 & 11.8 & 10.9 & 10.7 & 10.5 & 10.5 & 11.0\end{array}$ $\begin{array}{lllllllllll}76.0 & 10.9 & 11.1 & 11.1 & 10.6 & 11.5 & 11.4 & 10.5 & 10.0 & 11.0 & 10.2\end{array}$ $\begin{array}{lllllllllll}91.0 & 10.8 & 10.7 & 11.6 & 10.4 & 12.7 & 10.1 & 10.5 & 10.1 & 10.5 & 9.9\end{array}$ $\begin{array}{lllllllllll}107.0 & 10.2 & 11.0 & 11.4 & 10.7 & 13.3 & 8.7 & 10.7 & 9.9 & 10.6 & 10.0\end{array}$ $\begin{array}{lllllllllll}122.0 & 10.3 & 10.7 & 11.7 & 11.0 & 12.0 & 7.2 & 11.0 & 9.9 & 10.9 & 10.4\end{array}$ $\begin{array}{lllllllllll}137.0 & 10.2 & 11.2 & 11.9 & 10.5 & 10.7 & 6.0 & 10.6 & 9.8 & 10.5 & 10.8\end{array}$ $\begin{array}{lllllllllll}152.0 & 10.4 & 11.6 & 12.2 & 10.3 & 8.4 & 5.6 & 10.9 & 10.0 & 10.9 & 10.7\end{array}$ $\begin{array}{lllllllllll}167.0 & 10.9 & 11.4 & 12.0 & 11.0 & 6.7 & 6.1 & 11.0 & 9.8 & 11.1 & 10.8\end{array}$ $\begin{array}{llllllllllll}183.0 & 10.7 & 11.4 & 11.5 & 11.0 & 6.3 & 6.5 & 10.9 & 10.2 & 11.3 & 10.6\end{array}$ $\begin{array}{llllllllllll}198.0 & 11.0 & 11.4 & 11.8 & 10.6 & 6.6 & 6.8 & 11.8 & 10.4 & 11.3 & 11.2\end{array}$ $\begin{array}{lllllllllll}213.0 & 10.6 & 11.6 & 11.4 & 11.0 & 6.5 & 7.7 & 11.2 & 10.5 & 11.0 & 10.2\end{array}$ $\begin{array}{lllllllllll}229.0 & 10.5 & 10.6 & 11.5 & 11.1 & 7.0 & 7.5 & 11.1 & 10.4 & 11.1 & 10.6\end{array}$ $\begin{array}{lllllllllll}244.0 & 11.0 & 11.2 & 11.5 & 11.3 & 7.4 & 8.2 & 10.8 & 10.7 & 11.2 & 12.1\end{array}$ $\begin{array}{lllllllllll}259.0 & 12.4 & 12.3 & 12.2 & 11.7 & 8.0 & 9.2 & 11.6 & 11.7 & 12.9 & 22.0\end{array}$ $\begin{array}{lllllllllll}274.0 & 13.2 & 13.0 & 12.6 & 12.3 & 8.6 & 11.2 & 13.0 & 15.5 & 13.7 & 44.0\end{array}$

$\begin{array}{lllllllllll}\text { AVG } \% & 10.0 & 10.3 & 10.7 & 10.0 & 8.8 & 7.7 & 10.1 & 9.6 & 10.2 & 10.6\end{array}$

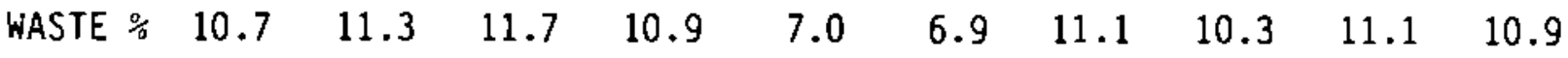
$\begin{array}{lllllllllll}\text { STRG } \mathrm{cm} & 27.5 & 28.4 & 29.4 & 27.6 & 24.1 & 21.3 & 27.9 & 26.4 & 27.9 & 29.0\end{array}$ 
DATE: $\quad 03-25-85$

DAY: $\quad 450$

PROBE: $\quad 5140$ STANDARD COUNTS: 11933

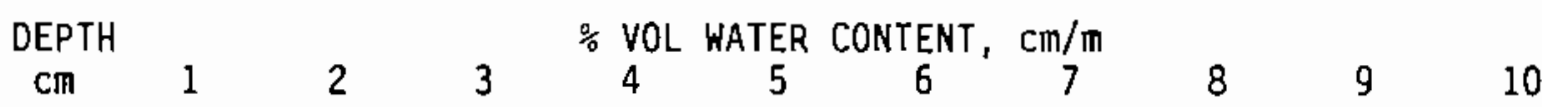

$\begin{array}{lllllllllll}30.0 & 7.2 & 8.1 & 8.0 & 8.1 & 7.8 & 8.5 & 8.6 & 8.0 & 6.6 & 6.6\end{array}$

$\begin{array}{lllllllllll}46.0 & 9.8 & 10.1 & 10.4 & 9.4 & 9.4 & 9.3 & 9.8 & 8.9 & 9.6 & 9.5\end{array}$

$\begin{array}{lllllllllll}61.0 & 10.8 & 10.8 & 10.9 & 10.1 & 10.5 & 10.4 & 10.4 & 9.6 & 10.1 & 10.2\end{array}$

$\begin{array}{lllllllllll}76.0 & 10.7 & 10.9 & 11.8 & 10.4 & 11.0 & 10.7 & 10.6 & 9.4 & 10.7 & 10.1\end{array}$

$\begin{array}{lllllllllll}91.0 & 10.5 & 10.6 & 11.4 & 10.1 & 12.0 & 10.3 & 10.6 & 9.3 & 10.6 & 9.7\end{array}$

$\begin{array}{lllllllllll}107.0 & 10.1 & 11.0 & 11.5 & 10.9 & 12.1 & 9.5 & 10.9 & 9.2 & 11.0 & 9.6\end{array}$

$\begin{array}{lllllllllll}122.0 & 10.4 & 10.8 & 11.5 & 11.0 & 10.3 & 8.2 & 11.1 & 9.2 & 10.6 & 10.0\end{array}$

$\begin{array}{lllllllllll}137.0 & 10.0 & 11.0 & 11.3 & 10.6 & 10.5 & 7.6 & 10.7 & 9.3 & 10.2 & 9.4\end{array}$

$\begin{array}{llllllllllll}152.0 & 10.3 & 11.7 & 11.7 & 10.6 & 9.4 & 7.3 & 11.0 & 9.0 & 11.1 & 10.1\end{array}$

$\begin{array}{lllllllllll}167.0 & 10.6 & 11.3 & 11.8 & 10.8 & 7.5 & 6.7 & 11.0 & 9.3 & 10.3 & 9.7\end{array}$

$\begin{array}{llllllllllll}183.0 & 10.9 & 11.6 & 11.3 & 10.9 & 6.7 & 6.1 & 10.6 & 9.1 & 10.7 & 9.8\end{array}$

$\begin{array}{llllllllllll}198.0 & 11.0 & 11.7 & 11.3 & 11.6 & 7.0 & 7.2 & 10.8 & 9.6 & 11.5 & 10.0\end{array}$

$\begin{array}{lllllllllll}213.0 & 10.9 & 11.5 & 11.3 & 11.5 & 6.9 & 7.7 & 11.0 & 9.9 & 11.7 & 9.7\end{array}$

$\begin{array}{lllllllllll}229.0 & 10.8 & 11.3 & 11.3 & 11.2 & 7.1 & 7.6 & 11.0 & 10.1 & 11.1 & 9.5\end{array}$

$\begin{array}{lllllllllll}244.0 & 11.4 & 11.8 & 11.8 & 10.9 & 7.3 & 8.1 & 12.0 & 10.2 & 11.2 & 11.1\end{array}$

$\begin{array}{lllllllllll}259.0 & 12.6 & 13.0 & 12.3 & 11.7 & 8.2 & 8.8 & 12.2 & 10.7 & 12.2 & 19.1\end{array}$

$\begin{array}{lllllllllll}274.0 & 13.6 & 13.9 & 13.5 & 12.9 & 8.6 & 10.4 & 13.9 & 13.9 & 14.1 & 44.0\end{array}$

$\begin{array}{lllllllllll}\text { AVG } \% & 9.9 & 10.4 & 10.6 & 10.0 & 8.4 & 7.9 & 10.1 & 8.9 & 10.0 & 9.7\end{array}$

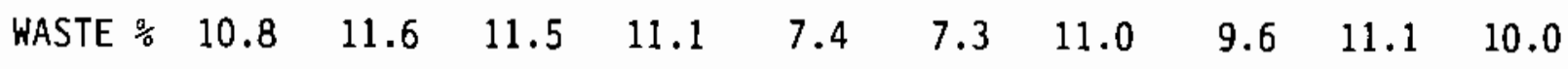
$\begin{array}{lllllllllll}\text { STRG Cm } & 27.2 & 28.6 & 29.1 & 27.4 & 23.2 & 21.7 & 27.9 & 24.4 & 27.4 & 26.5\end{array}$ 
DATE: $\quad 04-10-85$

$\begin{array}{lll}\text { DAY: } & 466 \\ \text { PROBE: } & 5140 \quad \text { STANDARD COUNTS: } 11861\end{array}$

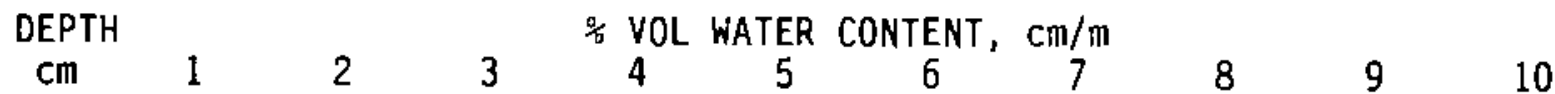

$\begin{array}{lllllllllll}30.0 & 6.3 & 6.9 & 6.7 & 6.7 & 6.8 & 7.7 & 6.9 & 7.4 & 5.4 & 6.8\end{array}$ $\begin{array}{lllllllllll}46.0 & 8.4 & 9.9 & 9.3 & 8.6 & 9.0 & 8.9 & 8.9 & 8.8 & 8.5 & 8.9\end{array}$ $\begin{array}{lllllllllll}61.0 & 9.8 & 10.4 & 10.3 & 9.5 & 10.0 & 9.6 & 9.9 & 9.7 & 9.6 & 10.2\end{array}$ $\begin{array}{lllllllllll}76.0 & 10.6 & 10.2 & 10.7 & 9.5 & 10.2 & 10.5 & 10.2 & 10.1 & 10.4 & 10.1\end{array}$ $\begin{array}{rrrrrrrrrrr}91.0 & 9.7 & 10.6 & 10.9 & 10.0 & 10.8 & 9.8 & 10.0 & 9.8 & 9.9 & 10.1\end{array}$ $\begin{array}{lllllllllll}107.0 & 9.7 & 10.5 & 11.0 & 10.8 & 11.1 & 9.4 & 10.2 & 9.5 & 10.8 & 10.1\end{array}$ $\begin{array}{lllllllllll}122.0 & 9.3 & 10.4 & 11.6 & 10.7 & 10.7 & 8.4 & 10.7 & 9.4 & 10.7 & 9.6\end{array}$ $\begin{array}{rrrrrrrrrrr}137.0 & 9.5 & 10.8 & 10.8 & 9.9 & 10.2 & 8.6 & 10.4 & 9.5 & 9.9 & 9.9\end{array}$ $\begin{array}{lllllllllll}152.0 & 9.3 & 11.2 & 11.3 & 10.4 & 9.5 & 7.8 & 10.7 & 9.5 & 10.0 & 10.9\end{array}$ $\begin{array}{lllllllllll}167.0 & 10.0 & 10.7 & 11.8 & 10.6 & 8.4 & 7.0 & 10.7 & 9.4 & 10.5 & 10.5\end{array}$ $\begin{array}{lllllllllll}183.0 & 10.3 & 11.3 & 11.1 & 10.7 & 7.4 & 6.2 & 10.9 & 9.4 & 10.3 & 10.5\end{array}$ $\begin{array}{lllllllllll}198.0 & 9.9 & 10.9 & 11.6 & 11.2 & 7.3 & 7.1 & 10.9 & 10.4 & 11.0 & 10.4\end{array}$ $\begin{array}{llllllllllll}213.0 & 10.4 & 11.1 & 11.2 & 11.2 & 7.4 & 7.5 & 11.0 & 10.1 & 10.8 & 10.6\end{array}$ $\begin{array}{llllllllllll}229.0 & 11.1 & 11.1 & 11.3 & 11.3 & 7.2 & 7.1 & 10.8 & 10.4 & 10.8 & 9.7\end{array}$ $\begin{array}{lllllllllll}244.0 & 10.3 & 11.2 & 11.6 & 11.2 & 7.4 & 8.0 & 11.2 & 10.4 & 11.0 & 10.4\end{array}$ $\begin{array}{lllllllllll}259.0 & 11.9 & 12.2 & 12.1 & 12.1 & 7.7 & 8.8 & 12.1 & 10.8 & 12.4 & 12.7\end{array}$ $\begin{array}{lllllllllll}274.0 & 13.1 & 13.6 & 13.4 & 14.4 & 8.6 & 10.5 & 13.3 & 14.0 & 12.7 & 18.8\end{array}$

$\begin{array}{lllllllllll}\text { AVG \% } & 9.2 & 10.0 & 10.2 & 9.7 & 8.3 & 7.8 & 9.7 & 9.1 & 9.5 & 9.5\end{array}$

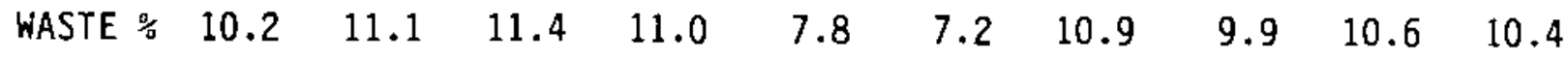
$\begin{array}{lllllllllll}\text { STRG cm } & 25.3 & 27.4 & 28.1 & 26.6 & 22.8 & 21.4 & 26.8 & 25.0 & 26.2 & 26.1\end{array}$ 


\begin{tabular}{|c|c|c|c|c|c|c|c|c|c|c|}
\hline $\begin{array}{l}\text { DATE: } \\
\text { DAY: } \\
\text { PROBE: }\end{array}$ & & & STANDARL & D COUNTS & S: $\quad 118$ & & & & & \\
\hline $\begin{array}{l}\text { DEPTH } \\
\mathrm{cm}\end{array}$ & 1 & 2 & 3 & $\begin{array}{l}\because \text { VOL WA } \\
4\end{array}$ & $\underset{5}{\text { ATER CO }}$ & $\begin{array}{l}\text { NTENT, } \\
6\end{array}$ & $\mathrm{~cm} / \mathrm{m}$ & 8 & 9 & 10 \\
\hline 30.0 & 6.0 & 6.7 & 6.4 & 6.1 & 6.6 & 7.2 & 7.2 & 7.2 & 5.8 & 5.9 \\
\hline 46.0 & 8.3 & 9.6 & 8.6 & 8.4 & 8.1 & 8.3 & 8.4 & 9.0 & 8.2 & 8.2 \\
\hline 61.0 & 10.3 & 10.0 & 9.9 & 9.5 & 9.7 & 9.2 & 9.7 & 9.8 & 9.8 & 10.0 \\
\hline 76.0 & 10.5 & 10.2 & 10.9 & 10.3 & 9.6 & 10.0 & 9.8 & 9.6 & 10.4 & 9.6 \\
\hline 91.0 & 10.2 & 10.1 & 10.2 & 10.2 & 10.6 & 9.5 & 10.4 & 9.6 & 10.3 & 9.7 \\
\hline 107.0 & 9.4 & 10.3 & 11.0 & 10.3 & 11.2 & 9.4 & 10.4 & 9.8 & 10.1 & 9.9 \\
\hline 122.0 & 9.0 & 10.6 & 10.7 & 10.2 & 10.1 & 8.5 & 10.5 & 9.3 & 10.4 & 9.7 \\
\hline 137.0 & 9.3 & 10.7 & 10.8 & 9.9 & 9.9 & 9.1 & 10.3 & 9.1 & 9.8 & 9.9 \\
\hline 152.0 & 9.5 & 10.6 & 11.1 & 10.2 & 9.3 & 8.9 & 10.3 & 9.6 & 10.4 & 11.0 \\
\hline 167.0 & 10.0 & 11.4 & 11.3 & 9.9 & 8.6 & 7.7 & 10.8 & 9.5 & 10.5 & 10.2 \\
\hline 183.0 & 9.7 & 11.0 & 10.3 & 10.9 & 8.3 & 7.0 & 10.6 & 9.6 & 10.5 & 9.9 \\
\hline 198.0 & 10.3 & 11.6 & 11.1 & 10.8 & 7.8 & 7.4 & 10.9 & 10.6 & 11.0 & 10.5 \\
\hline 213.0 & 10.5 & 11.0 & 11.2 & 11.5 & 7.3 & 8.0 & 10.7 & 10.7 & 11.0 & 9.8 \\
\hline 229.0 & 10.3 & 11.4 & 11.1 & 11.4 & 7.0 & 7.6 & 11.3 & 10.2 & 10.3 & 9.7 \\
\hline 244.0 & 10.5 & 11.8 & 11.7 & 11.3 & 7.2 & 8.1 & 11.3 & 10.3 & 11.1 & 10.8 \\
\hline 259.0 & 11.1 & 12.5 & 11.7 & 12.2 & 7.8 & 8.8 & 12.2 & 11.2 & 11.8 & 12.9 \\
\hline 274.0 & 13.3 & 14.2 & 13.9 & 14.2 & 8.7 & 10.8 & 14.2 & 14.3 & 12.9 & 18.8 \\
\hline
\end{tabular}

$\begin{array}{lllllllllll}\text { AVG \% } & 9.1 & 10.0 & 9.9 & 9.6 & 8.2 & 7.9 & 9.7 & 9.1 & 9.5 & 9.3\end{array}$ $\begin{array}{lllllllllll}\text { WASTE \% } & 10.1 & 11.3 & 11.1 & 10.9 & 7.9 & 7.8 & 10.8 & 10.1 & 10.7 & 10.3\end{array}$

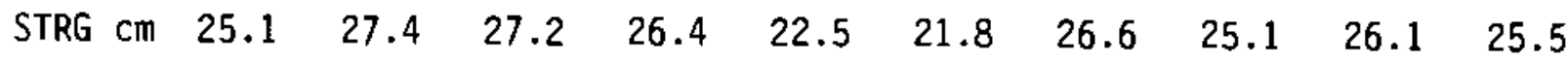


DATE : $\quad 05-08-85$

DAY: $\quad 494$

PROBE: $\quad 5140 \quad$ STANOARD COUNTS: 11920

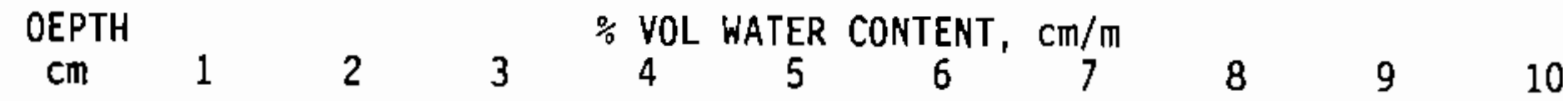

$\begin{array}{lllllllllll}30.0 & 5.9 & 6.5 & 5.7 & 5.9 & 6.1 & 6.1 & 6.8 & 6.7 & 5.0 & 5.1\end{array}$ $\begin{array}{lllllllllll}46.0 & 7.9 & 9.0 & 8.2 & 7.9 & 7.8 & 7.8 & 8.4 & 8.2 & 7.4 & 7.4\end{array}$ $\begin{array}{lllllllllll}61.0 & 9.9 & 9.9 & 9.8 & 9.1 & 8.3 & 8.7 & 9.6 & 8.8 & 8.8 & 8.8\end{array}$ $\begin{array}{lllllllllll}76.0 & 10.4 & 9.8 & 9.9 & 9.7 & 9.2 & 9.2 & 10.0 & 9.0 & 9.3 & 9.1\end{array}$ $\begin{array}{lllllllllll}91.0 & 9.5 & 9.6 & 10.0 & 10.0 & 10.1 & 9.1 & 10.2 & 9.3 & 9.7 & 9.2\end{array}$ $\begin{array}{lllllllllll}107.0 & 9.4 & 9.8 & 10.2 & 10.2 & 10.9 & 9.2 & 10.0 & 9.1 & 9.3 & 9.4\end{array}$ $\begin{array}{lllllllllll}122.0 & 9.3 & 9.8 & 10.2 & 9.9 & 10.0 & 8.1 & 10.2 & 8.5 & 9.6 & 9.7\end{array}$ $\begin{array}{lllllllllll}137.0 & 9.5 & 10.4 & 10.6 & 9.9 & 9.2 & 8.6 & 10.5 & 9.3 & 9.2 & 9.7\end{array}$ $\begin{array}{lllllllllll}152.0 & 9.8 & 9.9 & 10.5 & 10.2 & 9.2 & 8.4 & 10.4 & 8.9 & 9.7 & 10.1\end{array}$ $\begin{array}{lllllllllll}167.0 & 10.0 & 10.1 & 10.7 & 10.1 & 8.7 & 8.1 & 10.2 & 8.7 & 10.0 & 10.2\end{array}$ $\begin{array}{lllllllllll}183.0 & 10.2 & 10.3 & 10.8 & 10.3 & 8.3 & 7.4 & 10.2 & 8.9 & 10.1 & 9.6\end{array}$ $\begin{array}{lllllllllll}198.0 & 10.2 & 10.6 & 11.1 & 10.5 & 7.9 & 7.2 & 10.7 & 9.6 & 10.3 & 10.1\end{array}$ $\begin{array}{lllllllllll}213.0 & 10.5 & 10.5 & 11.4 & 10.8 & 7.7 & 7.9 & 10.6 & 9.6 & 10.0 & 10.0\end{array}$ $\begin{array}{lllllllllll}229.0 & 10.6 & 10.3 & 10.7 & 10.7 & 7.7 & 7.4 & 10.9 & 9.5 & 10.3 & 9.8\end{array}$ $\begin{array}{lllllllllll}244.0 & 11.2 & 10.9 & 11.3 & 10.9 & 7.4 & 8.1 & 10.9 & 9.7 & 10.5 & 10.6\end{array}$ $\begin{array}{llllllllllll}259.0 & 11.9 & 11.5 & 12.7 & 11.8 & 7.9 & 9.1 & 11.9 & 11.0 & 12.0 & 12.8\end{array}$ $\begin{array}{lllllllllll}274.0 & 13.9 & 13.2 & 19.5 & 14.0 & 8.5 & 10.6 & 13.9 & 14.3 & 13.1 & 20.4\end{array}$

$\begin{array}{lllllllllll}\text { AVG \% } & 9.2 & 9.3 & 9.6 & 9.3 & 8.0 & 7.7 & 9.5 & 8.5 & 8.9 & 8.9\end{array}$

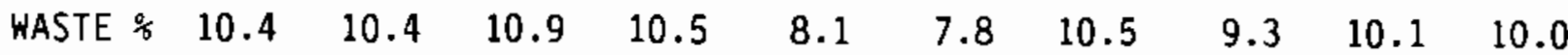
$\begin{array}{lllllllllll}\text { STRG cm } & 25.3 & 25.7 & 26.5 & 25.5 & 22.1 & 21.1 & 26.1 & 23.4 & 24.5 & 24.5\end{array}$ 
DATE: $\quad 05-21-85$

DAY: $\quad 507$

PROBE: $\quad 5140$ STANDARD COUNTS: 11823

\begin{tabular}{|c|c|c|c|c|c|c|c|c|c|c|}
\hline $\begin{array}{l}\text { DEPTH } \\
\mathrm{cm}\end{array}$ & 1 & 2 & 3 & $\begin{array}{l}\text { VOL } \\
4\end{array}$ & $\begin{array}{l}\text { TER C } \\
5\end{array}$ & $\begin{array}{l}\text { ENT, } \\
6\end{array}$ & $\pi /$ m & 8 & 9 & 10 \\
\hline 30.0 & 5.4 & 11.4 & 6.0 & 5.8 & 5.6 & 5.5 & 6.5 & 6.3 & 4.6 & 4.5 \\
\hline 46.0 & 8.2 & 8.7 & 8.6 & 7.7 & 7.6 & 7.4 & 8.3 & 8.1 & 7.6 & 7.0 \\
\hline 61.0 & 9.5 & 9.5 & 10.3 & 8.8 & 8.7 & 8.1 & 9.2 & 9.3 & 8.7 & 9.0 \\
\hline 76.0 & 10.1 & 9.7 & 10.0 & 9.4 & 8.8 & 8.7 & 9.6 & 9.2 & 9.5 & 9.2 \\
\hline 91.0 & 9.3 & 9.3 & 10.1 & 9.3 & 9.6 & 8.6 & 9.4 & 9.4 & 9.7 & 9.1 \\
\hline 07.0 & 9.5 & 9.9 & 10.4 & 9.7 & 9.7 & 8.3 & 9.8 & 9.4 & 9.6 & 9.6 \\
\hline 22.0 & 9.6 & 9.7 & 10.6 & 9.5 & 9.1 & 8.1 & 10.3 & 9.4 & 9.4 & 10.0 \\
\hline 137.0 & 9.3 & 10.0 & 10.8 & 9.5 & 8.9 & 7.8 & 10.0 & 9.3 & 9.8 & 9.8 \\
\hline 52.0 & 9.8 & 10.2 & 10.6 & 10.0 & 8.7 & 8.0 & 9.5 & 9.4 & 9.7 & 10.4 \\
\hline 67.0 & 10.6 & 10.0 & 10.8 & 10.5 & 8.3 & 8.1 & 9.7 & 8.8 & 10.2 & 10.1 \\
\hline 83.0 & 10.0 & 10.0 & 11.1 & 10.8 & 8.5 & 7.3 & 10.0 & 8.9 & 10.5 & 10.1 \\
\hline 98.0 & 10.5 & 10.4 & 10.9 & 10.5 & 8.5 & 7.7 & 9.7 & 9.7 & 10.6 & 10.5 \\
\hline 13.0 & 10.7 & 9.9 & 11.2 & 10.8 & 7.5 & 7.5 & 10.4 & 10.3 & 10.2 & 9.7 \\
\hline 29.0 & 10.9 & 10.1 & 11.5 & 10.7 & 7.3 & 7.4 & 10.3 & 9.8 & 10.1 & 9.7 \\
\hline 44.0 & 11.5 & 11.0 & 11.3 & 10.8 & 7.5 & 7.9 & 10.4 & 10.2 & 10.6 & 11.1 \\
\hline 259.0 & 12.5 & 11.4 & 11.9 & 11.6 & 7.9 & 8.7 & 11.3 & 11.2 & 11.9 & 12.1 \\
\hline 74.0 & 14.9 & 13.5 & 14.1 & 14.6 & 8.4 & 10.6 & 13.7 & 15.2 & 13.5 & 20.9 \\
\hline
\end{tabular}

$\begin{array}{lllllllllll}\text { AVG } \% & 9.3 & 9.5 & 9.8 & 9.1 & 7.8 & 7.4 & 9.1 & 8.7 & 9.0 & 8.9\end{array}$

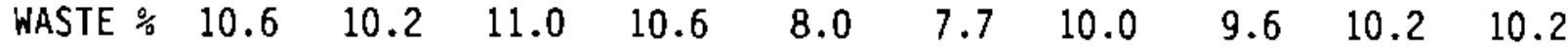
$\begin{array}{lllllllllll}\text { STRG cm } & 25.5 & 26.1 & 26.9 & 25.1 & 21.4 & 20.2 & 25.0 & 24.1 & 24.7 & 24.6\end{array}$ 
$\begin{array}{lcl}\text { DATE: } & 06-17-85 & \\ \text { DAY: } & 534 & \\ \text { PROBE: } & 2499 \quad \text { STANDARD COUNTS: } 33930\end{array}$

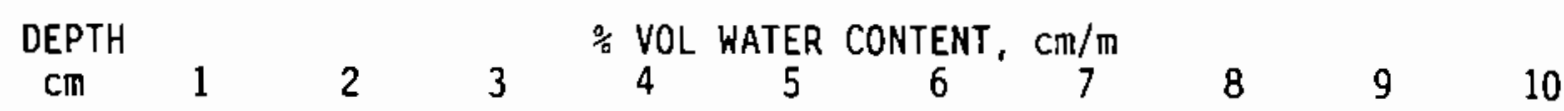

$\begin{array}{lllllllllll}30.0 & 5.5 & 6.2 & 5.1 & 5.4 & 5.4 & 6.4 & 6.3 & 6.7 & 4.9 & 4.2\end{array}$ $\begin{array}{lllllllllll}46.0 & 7.4 & 8.4 & 8.3 & 6.9 & 7.8 & 7.6 & 8.1 & 8.4 & 7.6 & 7.3\end{array}$ $\begin{array}{lllllllllll}61.0 & 9.7 & 9.2 & 9.8 & 8.7 & 8.4 & 8.2 & 9.1 & 9.2 & 9.2 & 8.7\end{array}$ $\begin{array}{lllllllllll}76.0 & 9.9 & 9.5 & 9.5 & 9.0 & 8.6 & 8.7 & 9.1 & 9.3 & 10.4 & 8.6\end{array}$ $\begin{array}{lllllllllll}91.0 & 9.1 & 9.7 & 9.9 & 9.4 & 9.3 & 8.7 & 9.4 & 9.1 & 10.0 & 9.3\end{array}$ $\begin{array}{lllllllllll}107.0 & 9.1 & 9.6 & 10.1 & 9.7 & 9.5 & 8.7 & 9.8 & 9.2 & 10.2 & 9.5\end{array}$ $\begin{array}{lllllllllll}122.0 & 9.2 & 9.6 & 10.7 & 9.7 & 9.1 & 8.5 & 10.3 & 9.6 & 10.1 & 9.7\end{array}$ $\begin{array}{lllllllllll}137.0 & 9.2 & 9.4 & 10.7 & 9.4 & 8.8 & 8.6 & 9.8 & 9.7 & 10.0 & 9.7\end{array}$ $\begin{array}{lllllllllll}152.0 & 9.6 & 9.7 & 10.9 & 10.4 & 9.0 & 8.7 & 10.1 & 10.2 & 11.1 & 11.3\end{array}$ $\begin{array}{llllllllllll}167.0 & 10.2 & 10.6 & 11.2 & 10.7 & 8.5 & 8.5 & 10.1 & 9.9 & 12.1 & 10.5\end{array}$ $\begin{array}{lllllllllll}183.0 & 10.0 & 10.5 & 11.1 & 10.8 & 8.7 & 8.0 & 10.6 & 10.4 & 12.4 & 10.4\end{array}$ $\begin{array}{lllllllllll}198.0 & 9.9 & 10.7 & 11.9 & 11.2 & 9.3 & 8.4 & 10.9 & 11.2 & 13.3 & 10.8\end{array}$ $\begin{array}{lllllllllll}213.0 & 10.8 & 11.0 & 12.0 & 11.7 & 8.7 & 8.6 & 11.5 & 11.2 & 13.2 & 10.8\end{array}$ $\begin{array}{llllllllllll}229.0 & 8.1 & 10.7 & 12.2 & 11.8 & 8.4 & 8.2 & 11.5 & 11.3 & 12.7 & 10.7\end{array}$ $\begin{array}{lllllllllll}244.0 & 11.1 & 11.1 & 12.4 & 12.2 & 7.9 & 8.7 & 12.1 & 11.0 & 12.5 & 11.9\end{array}$ $\begin{array}{lllllllllll}259.0 & 11.8 & 12.2 & 12.0 & 13.0 & 8.5 & 9.0 & 13.2 & 11.8 & 13.2 & 14.3\end{array}$ $\begin{array}{lllllllllll}274.0 & 14.7 & 14.8 & 15.3 & 18.7 & 9.2 & 11.1 & 17.2 & 16.8 & 15.4 & 25.9\end{array}$

$\begin{array}{lllllllllll}\text { AVG } \% & 8.9 & 9.3 & 9.9 & 9.4 & 8.0 & 7.8 & 9.5 & 9.3 & 10.2 & 9.3\end{array}$ $\begin{array}{lllllllllll}\text { WASTE \% } & 9.9 & 10.6 & 11.7 & 11.3 & 8.6 & 8.4 & 11.0 & 10.7 & 12.5 & 10.9\end{array}$ $\begin{array}{lllllllllll}\text { STRG } \mathrm{Cm} & 24.4 & 25.5 & 27.2 & 25.9 & 22.0 & 21.6 & 26.2 & 25.6 & 28.0 & 25.5\end{array}$ 
DATE: $\quad 07-11-85$

DAY: $\quad 558$

PROBE: $\quad 6031$ STANDARD COUNTS: 8486

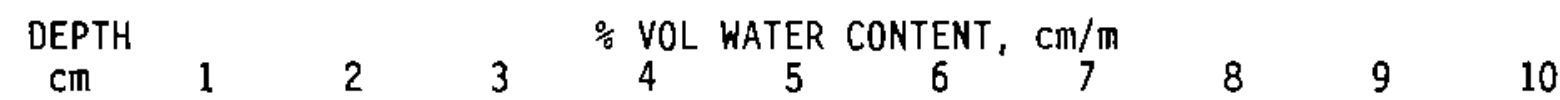

$\begin{array}{lllllllllll}30.0 & 3.2 & 3.8 & 3.8 & 3.9 & 3.8 & 4.5 & 4.6 & 4.3 & 2.8 & 2.4\end{array}$

$\begin{array}{lllllllllll}46.0 & 6.7 & 7.3 & 7.5 & 6.8 & 6.3 & 6.6 & 7.3 & 7.5 & 6.1 & 6.2\end{array}$

$\begin{array}{lllllllllll}61.0 & 8.6 & 8.2 & 8.4 & 7.4 & 7.7 & 7.3 & 8.2 & 8.8 & 8.1 & 8.0\end{array}$

$\begin{array}{lllllllllll}76.0 & 8.6 & 8.4 & 9.3 & 8.8 & 8.8 & 8.3 & 9.1 & 9.0 & 9.2 & 8.0\end{array}$

$\begin{array}{lllllllllll}91.0 & 8.6 & 8.8 & 9.6 & 9.1 & 9.0 & 8.5 & 9.3 & 8.6 & 9.0 & 8.1\end{array}$

$\begin{array}{lllllllllll}107.0 & 8.3 & 9.4 & 9.4 & 8.8 & 9.3 & 8.5 & 9.3 & 9.1 & 9.5 & 8.5\end{array}$

$\begin{array}{lllllllllll}122.0 & 8.9 & 9.2 & 11.1 & 9.2 & 8.3 & 7.7 & 9.6 & 9.0 & 9.5 & 9.0\end{array}$

$\begin{array}{lllllllllll}137.0 & 8.5 & 9.3 & 10.5 & 9.8 & 8.0 & 8.8 & 9.3 & 8.9 & 9.4 & 9.3\end{array}$

$\begin{array}{lllllllllll}152.0 & 9.8 & 9.2 & 10.3 & 10.1 & 8.4 & 8.6 & 9.8 & 9.1 & 9.6 & 10.0\end{array}$

$\begin{array}{lllllllllll}167.0 & 9.2 & 10.0 & 10.5 & 9.9 & 8.3 & 8.5 & 9.7 & 9.0 & 10.5 & 8.8\end{array}$

$\begin{array}{lllllllllll}183.0 & 10.2 & 10.1 & 10.1 & 10.0 & 8.7 & 8.5 & 10.0 & 9.0 & 10.2 & 9.5\end{array}$

$\begin{array}{lllllllllll}198.0 & 9.9 & 10.1 & 10.9 & 10.4 & 8.7 & 7.7 & 9.8 & 9.8 & 10.8 & 9.8\end{array}$

$\begin{array}{lllllllllll}213.0 & 10.2 & 10.2 & 11.3 & 10.3 & 9.0 & 8.4 & 10.1 & 9.9 & 9.9 & 9.9\end{array}$

$\begin{array}{lllllllllll}229.0 & 10.0 & 10.6 & 10.5 & 10.2 & 8.1 & 8.2 & 10.2 & 10.1 & 10.1 & 9.4\end{array}$

$\begin{array}{lllllllllll}244.0 & 9.8 & 11.1 & 11.1 & 10.2 & 7.9 & 8.3 & 10.1 & 9.9 & 10.5 & 10.2\end{array}$

$\begin{array}{lllllllllll}259.0 & 11.4 & 12.3 & 11.5 & 11.6 & 8.0 & 9.3 & 11.6 & 10.7 & 12.6 & 13.6\end{array}$

$\begin{array}{lllllllllll}274.0 & 14.2 & 14.1 & 13.6 & 13.6 & 8.9 & 11.2 & 13.3 & 14.6 & 12.6 & 24.9\end{array}$

$\begin{array}{lllllllllll}\text { AVG \% } & 8.3 & 8.7 & 9.2 & 8.6 & 7.6 & 7.5 & 8.7 & 8.4 & 8.7 & 8.3\end{array}$ $\begin{array}{lllllllllll}\text { WASTE } \% 5 & 9.9 & 10.2 & 10.7 & 10.1 & 8.4 & 8.3 & 10.0 & 9.6 & 10.2 & 9.6\end{array}$ $\begin{array}{lllllllllll}\text { STRG Cm } & 23.0 & 23.9 & 25.2 & 23.7 & 20.8 & 20.6 & 23.9 & 23.1 & 23.9 & 22.7\end{array}$ 
DATE: $\quad 08-14-85$

DAY: $\quad 592$

PROBE: $\quad 6031$ STANDARD COUNTS: 8504

\begin{tabular}{|c|c|c|c|c|c|c|c|c|c|c|}
\hline $\begin{array}{l}\text { DEPTH } \\
\text { cm }\end{array}$ & 1 & 2 & 3 & $\begin{array}{l}\text { VOL W } \\
4\end{array}$ & $\begin{array}{l}\text { ER CO } \\
5\end{array}$ & $\begin{array}{l}\text { ENT, } \\
6\end{array}$ & $c \mathrm{~cm} / \mathrm{m}$ & 8 & 9 & 10 \\
\hline 30.0 & 2.9 & 3.2 & 3.5 & 3.5 & 3.4 & 3.8 & 4.0 & 3.8 & 1.9 & 2.6 \\
\hline 45.0 & 6.4 & 6.7 & 6.6 & 5.6 & 6.3 & 5.9 & 6.4 & 5.7 & 5.9 & 5.5 \\
\hline 60.0 & 7.7 & 7.5 & 7.9 & 6.9 & 6.9 & 6.8 & 7.2 & 7.3 & 7.4 & 6.7 \\
\hline 75.0 & 8.7 & 7.5 & 7.7 & 7.6 & 7.4 & 7.2 & 8.2 & 7.5 & 8.4 & 7.1 \\
\hline 90.0 & 8.1 & 7.4 & 9.0 & 8.3 & 8.0 & 7.3 & 8.2 & 7.9 & 8.2 & 7.4 \\
\hline 105.0 & 7.6 & 8.3 & 9.3 & 9.1 & 8.2 & 7.8 & 8.7 & 8.6 & 9.4 & 7.8 \\
\hline 120.0 & 7.8 & 8.1 & 9.2 & 9.1 & 7.6 & 7.4 & 8.4 & 8.7 & 8.8 & 8.2 \\
\hline 135.0 & 8.0 & 8.5 & 9.6 & 8.2 & 8.3 & 8.4 & 9.4 & 8.1 & 8.7 & 7.7 \\
\hline 150.0 & 9.0 & 8.5 & 9.7 & 9.4 & 7.9 & 8.2 & 9.5 & 8.0 & 9.7 & 8.8 \\
\hline 165.0 & 8.9 & 8.5 & 10.0 & 9.3 & 8.1 & 8.6 & 9.4 & 8.0 & 10.2 & 8.8 \\
\hline 180.0 & 9.3 & 8.8 & 9.7 & 9.5 & 7.9 & 8.1 & 9.4 & 8.2 & 9.7 & 8.9 \\
\hline 195.0 & 9.7 & 9.4 & 10.0 & 10.1 & 8.4 & 8.2 & 9.2 & 9.0 & 10.4 & 9.1 \\
\hline 210.0 & 9.7 & 9.4 & 10.4 & 10.1 & 8.9 & 9.1 & 9.7 & 8.6 & 10.7 & 8.6 \\
\hline 225.0 & 9.6 & 9.6 & 11.0 & 10.6 & 8.1 & 9.0 & 10.1 & 9.0 & 10.0 & 8.5 \\
\hline 240.0 & 9.8 & 10.1 & 10.9 & 10.1 & 8.6 & 9.3 & 10.5 & 9.0 & 9.6 & 8.5 \\
\hline 255.0 & 11.7 & 12.0 & 11.7 & 11.3 & 8.1 & 9.4 & 11.3 & 9.8 & 11.4 & 8.5 \\
\hline 270.0 & 13.6 & 12.6 & 13.4 & 13.6 & 9.3 & 13.1 & 13.5 & 12.4 & 13.4 & 8.5 \\
\hline
\end{tabular}

$\begin{array}{lllllllllll}\text { AVG } \% & 7.9 & 7.8 & 8.6 & 8.2 & 7.2 & 7.3 & 8.2 & 7.5 & 8.3 & 7.2\end{array}$ $\begin{array}{lllllllllll}\text { WASTE \% } & 9.4 & 9.2 & 10.3 & 9.9 & 8.3 & 8.7 & 9.7 & 8.5 & 10.0 & 8.7\end{array}$ $\begin{array}{lllllllllll}\text { STRG Cm } & 21.8 & 21.6 & 23.7 & 22.4 & 19.8 & 20.2 & 22.6 & 20.6 & 22.7 & 19.9\end{array}$ 


\begin{tabular}{|c|c|c|c|c|c|c|c|c|c|c|}
\hline $\begin{array}{l}\text { DATE: } \\
\text { DAY: } \\
\text { PROBE: }\end{array}$ & $\begin{array}{r}09-0 \\
61 \\
60\end{array}$ & & STANDARL & D COUNTS & & 3542 & & & & \\
\hline $\begin{array}{l}\text { DEPTH } \\
\mathrm{cm}\end{array}$ & 1 & 2 & 3 & $\begin{array}{l}\% \text { VOL WAT } \\
4\end{array}$ & $\begin{array}{l}\text { ATER C } \\
5\end{array}$ & $\begin{array}{l}\text { ONTENT, } \\
6\end{array}$ & $\mathrm{~cm} / \mathrm{m}$ & 8 & 9 & 10 \\
\hline 30.0 & 2.5 & 2.8 & 3.5 & 3.6 & 3.3 & 3.7 & 3.5 & 3.7 & 1.6 & 2.0 \\
\hline 45.0 & 5.7 & 6.2 & 5.9 & 5.5 & 5.8 & 5.8 & 6.3 & 6.1 & 5.3 & 5.1 \\
\hline 60.0 & 7.4 & 6.1 & 7.9 & 6.4 & 6.2 & 7.2 & 7.3 & 6.8 & 6.7 & 6.8 \\
\hline 75.0 & 7.0 & 7.2 & 8.5 & 7.6 & 6.8 & 6.9 & 8.1 & 7.3 & 6.9 & 7.1 \\
\hline 90.0 & 8.0 & 7.4 & 8.4 & 7.8 & 7.8 & 7.4 & 8.1 & 7.6 & 8.5 & 7.1 \\
\hline 105.0 & 7.4 & 8.2 & 8.3 & 8.2 & 8.2 & 7.3 & 7.8 & 7.7 & 8.0 & 6.8 \\
\hline 120.0 & 7.8 & 8.4 & 9.8 & 8.4 & 7.0 & 7.2 & 8.3 & 8.1 & 8.7 & 7.1 \\
\hline 135.0 & 8.5 & 8.1 & 9.5 & 8.1 & 7.7 & 7.3 & 8.3 & 7.7 & 8.3 & 7.7 \\
\hline 150.0 & 8.4 & 8.3 & 9.0 & 8.3 & 7.7 & 8.1 & 8.5 & 7.7 & 9.1 & 8.0 \\
\hline 165.0 & 8.8 & 8.3 & 9.7 & 9.5 & 8.0 & 7.9 & 8.6 & 7.9 & 9.1 & 7.4 \\
\hline 180.0 & 8.9 & 8.7 & 9.7 & 8.8 & 7.9 & 7.8 & 8.7 & 8.1 & 9.9 & 7.5 \\
\hline 195.0 & 9.0 & 9.5 & 9.8 & 9.3 & 9.0 & 8.4 & 9.6 & 8.6 & 10.1 & 8.1 \\
\hline 210.0 & 9.3 & 9.2 & 10.3 & 9.8 & 8.7 & 8.5 & 9.6 & 9.3 & 10.4 & 7.5 \\
\hline 225.0 & 8.8 & 9.9 & 10.4 & 10.0 & 8.4 & 8.5 & 10.1 & 9.4 & 9.8 & 8.2 \\
\hline 240.0 & 9.3 & 10.1 & 10.5 & 10.3 & 8.8 & 8.6 & 9.5 & 9.4 & 9.2 & 8.2 \\
\hline 255.0 & 10.5 & 10.6 & 11.2 & 11.7 & 8.7 & 9.3 & 9.9 & 10.3 & 10.9 & 8.2 \\
\hline 270.0 & 12.9 & 12.3 & 12.9 & 12.6 & 10.2 & 11.0 & 11.1 & 12.9 & 12.0 & 8.2 \\
\hline
\end{tabular}

AVG \% $\quad \begin{array}{llllllllll}7.5 & 7.6 & 8.4 & 7.8 & 7.1 & 7.1 & 7.8 & 7.4 & 7.8 & 6.6\end{array}$

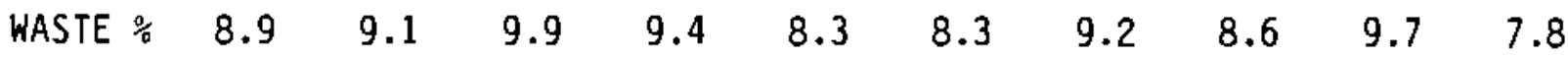
$\begin{array}{lllllllllll}\text { STRG } \mathrm{cm} & 20.6 & 20.9 & 23.1 & 21.5 & 19.4 & 19.4 & 21.4 & 20.3 & 21.4 & 18.3\end{array}$ 


\begin{tabular}{|c|c|c|c|c|c|c|c|c|c|c|}
\hline \multirow{2}{*}{$\begin{array}{l}\text { DATE: } \\
\text { DAY: } \\
\text { PROBE: } \\
\text { DEPTH } \\
\text { CM }\end{array}$} & \multicolumn{2}{|c|}{$\begin{array}{c}09-25-85 \\
634 \\
6031\end{array}$} & STANDARD & \multicolumn{2}{|c|}{ D COUNTS: } & \multicolumn{2}{|c|}{8571} & \multirow[b]{2}{*}{8} & \multirow[b]{2}{*}{9} & \multirow[b]{2}{*}{10} \\
\hline & 1 & 2 & 3 & $\begin{array}{l}6 \text { VOL WA } \\
4\end{array}$ & $\begin{array}{l}\text { ATER CO } \\
5\end{array}$ & $\begin{array}{l}\text { ONTENT, } \\
6\end{array}$ & $\begin{array}{c}\mathrm{cm} / \mathrm{m} \\
7\end{array}$ & & & \\
\hline 30.0 & 3.4 & 3.5 & 3.9 & 3.6 & 3.8 & 3.8 & 3.8 & 4.2 & 2.8 & 3.1 \\
\hline 45.0 & 5.8 & 6.3 & 6.5 & 5.6 & 5.2 & 6.3 & 5.8 & 5.8 & 5.6 & 5.4 \\
\hline 60.0 & 6.6 & 6.8 & 7.6 & 6.4 & 6.7 & 6.8 & 6.5 & 6.9 & 6.2 & 6.6 \\
\hline 75.0 & 7.1 & 6.5 & 7.6 & 7.1 & 6.2 & 6.9 & 7.7 & 7.1 & 7.4 & 6.4 \\
\hline 90.0 & 7.7 & 7.3 & 8.0 & 6.8 & 7.3 & 7.5 & 7.0 & 7.4 & 7.2 & 6.6 \\
\hline 105.0 & 7.8 & 8.3 & 8.4 & 7.9 & 7.7 & 7.4 & 7.4 & 7.7 & 7.7 & 7.6 \\
\hline 120.0 & 7.8 & 8.3 & 8.7 & 7.8 & 7.4 & 6.5 & 8.2 & 7.9 & 8.0 & 8.0 \\
\hline 135.0 & 7.0 & 8.0 & 8.7 & 8.1 & 7.2 & 7.2 & 8.2 & 7.6 & 8.0 & 7.3 \\
\hline 150.0 & 8.3 & 8.6 & 9.2 & 8.1 & 7.4 & 8.6 & 8.4 & 8.3 & 8.3 & 8.5 \\
\hline 165.0 & 9.2 & 7.9 & 9.8 & 8.8 & 7.1 & 8.2 & 9.1 & 7.5 & 8.9 & 8.0 \\
\hline 180.0 & 8.9 & 8.4 & 9.4 & 9.2 & 8.0 & 7.6 & 8.8 & 7.4 & 9.5 & 8.0 \\
\hline 195.0 & 9.5 & 8.8 & 10.0 & 8.8 & 7.7 & 8.3 & 8.9 & 9.0 & 10.2 & 8.7 \\
\hline 210.0 & 9.5 & 9.4 & 10.8 & 9.3 & 8.1 & 8.3 & 9.1 & 8.6 & 9.9 & 8.4 \\
\hline 225.0 & 8.8 & 9.0 & 10.1 & 8.9 & 8.6 & 8.8 & 9.6 & 9.3 & 9.3 & 8.2 \\
\hline 240.0 & 10.4 & 9.6 & 9.7 & 9.4 & 8.1 & 8.8 & 8.7 & 9.7 & 10.0 & 8.2 \\
\hline 255.0 & 13.4 & 10.7 & 11.0 & 10.9 & 8.8 & 10.0 & 10.1 & 9.0 & 10.6 & 8.2 \\
\hline 270.0 & 12.7 & 13.0 & 11.9 & 12.9 & 9.9 & 11.6 & 12.3 & 12.2 & 12.5 & 8.2 \\
\hline AVG \% & 7.7 & 7.5 & 8.2 & 7.5 & 6.8 & 7.1 & 7.5 & 7.3 & 7.6 & 6.9 \\
\hline WASTE \% & 9.2 & 8.8 & 9.9 & 8.9 & 7.8 & 8.4 & 8.9 & 8.5 & 9.5 & 8.3 \\
\hline STRG cm & 21.2 & 20.6 & 22.6 & 20.5 & 18.6 & 19.6 & 20.6 & 20.0 & 21.0 & 19.0 \\
\hline
\end{tabular}


DATE: $\quad 10-23-85$

OAY: $\quad 662$

PROBE: $\quad 6031$ STANDARD COUNTS: 8597

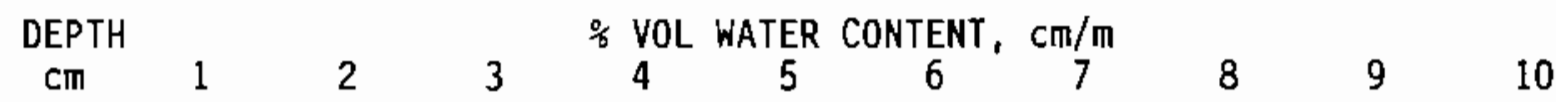

$\begin{array}{lllllllllll}30.0 & 3.6 & 3.9 & 4.0 & 3.6 & 4.1 & 4.1 & 4.3 & 5.6 & 3.3 & 1.4\end{array}$

$\begin{array}{lllllllllll}45.0 & 5.1 & 5.9 & 6.4 & 5.6 & 5.8 & 5.2 & 5.7 & 6.7 & 5.2 & 5.5\end{array}$

$\begin{array}{lllllllllll}60.0 & 7.0 & 7.1 & 7.3 & 6.1 & 6.0 & 6.3 & 6.9 & 6.7 & 6.7 & 6.3\end{array}$

$\begin{array}{lllllllllll}75.0 & 7.0 & 6.5 & 7.0 & 6.7 & 7.0 & 5.8 & 6.8 & 6.2 & 7.0 & 6.6\end{array}$

$\begin{array}{lllllllllll}90.0 & 6.9 & 7.7 & 6.9 & 6.7 & 7.1 & 6.1 & 6.6 & 7.3 & 7.7 & 6.3\end{array}$

$\begin{array}{lllllllllll}105.0 & 6.8 & 7.3 & 8.4 & 7.5 & 7.1 & 6.4 & 7.5 & 7.4 & 7.5 & 6.4\end{array}$

$\begin{array}{lllllllllll}120.0 & 7.2 & 7.5 & 8.8 & 8.0 & 6.9 & 6.8 & 7.4 & 7.6 & 7.7 & 7.1\end{array}$

$\begin{array}{lllllllllll}135.0 & 7.6 & 8.1 & 8.8 & 7.0 & 6.2 & 7.2 & 7.8 & 7.4 & 7.6 & 6.9\end{array}$

$\begin{array}{lllllllllll}150.0 & 7.5 & 8.3 & 8.8 & 7.6 & 6.6 & 7.2 & 7.6 & 7.6 & 8.3 & 8.4\end{array}$

$\begin{array}{lllllllllll}165.0 & 8.5 & 7.9 & 9.2 & 8.6 & 6.7 & 7.2 & 7.7 & 7.7 & 8.7 & 7.4\end{array}$

$\begin{array}{lllllllllll}180.0 & 8.2 & 8.5 & 9.0 & 9.1 & 7.2 & 7.3 & 7.9 & 7.5 & 8.9 & 7.4\end{array}$

$\begin{array}{lllllllllll}195.0 & 8.6 & 8.9 & 8.9 & 9.0 & 7.6 & 7.5 & 8.2 & 8.1 & 8.9 & 7.3\end{array}$

$\begin{array}{lllllllllll}210.0 & 8.2 & 9.5 & 9.7 & 8.6 & 7.9 & 8.3 & 8.1 & 8.1 & 9.8 & 8.5\end{array}$

$\begin{array}{lllllllllll}225.0 & 8.0 & 8.8 & 9.3 & 9.4 & 7.7 & 7.3 & 8.6 & 8.5 & 9.7 & 7.6\end{array}$

$\begin{array}{lllllllllll}240.0 & 8.3 & 9.2 & 9.6 & 9.3 & 8.0 & 8.2 & 8.4 & 9.2 & 9.6 & 8.1\end{array}$

$\begin{array}{lllllllllll}255.0 & 9.8 & 10.8 & 10.7 & 10.2 & 8.4 & 8.6 & 9.1 & 9.7 & 11.2 & 10.1\end{array}$

$\begin{array}{lllllllllll}270.0 & 12.2 & 12.1 & 11.8 & 12.9 & 10.1 & 10.1 & 11.1 & 11.9 & 12.7 & 13.5\end{array}$

$\begin{array}{lllllllllll}\text { AVG \% } & 6.9 & 7.4 & 7.8 & 7.2 & 6.5 & 6.4 & 7.0 & 7.1 & 7.5 & 6.6\end{array}$

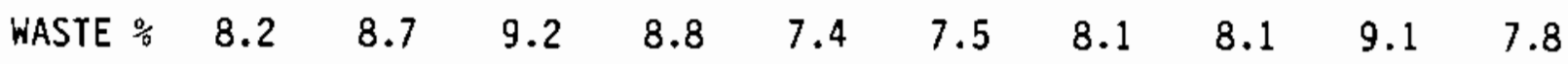
$\begin{array}{lllllllllll}\text { STRG } \mathrm{cm} & 19.1 & 20.4 & 21.5 & 19.9 & 17.8 & 17.7 & 19.2 & 19.6 & 20.7 & 18.0\end{array}$ 


\begin{tabular}{|c|c|c|c|c|c|c|c|c|c|c|}
\hline $\begin{array}{l}\text { DATE: } \\
\text { DAY: } \\
\text { PROBE: }\end{array}$ & $\begin{array}{r}11-1 \\
68 \\
60\end{array}$ & & STANDARD & D COUNTS: & 863 & & & & & \\
\hline $\begin{array}{l}\text { DEPTH } \\
\mathrm{cm}\end{array}$ & 1 & 2 & 3 & $\begin{array}{l}\% \text { VOL WATE } \\
4\end{array}$ & $\mathrm{CON}$ & $\begin{array}{l}\text { NTENT, } \\
6\end{array}$ & $\mathrm{~cm} / \mathrm{m}$ & 8 & 9 & 10 \\
\hline 30.0 & 4.4 & 4.5 & 5.0 & 4.5 & 4.5 & 4.7 & 5.1 & 5.2 & 4.1 & 4.1 \\
\hline 45.0 & 5.3 & 6.1 & 6.1 & 5.3 & 5.3 & 5.1 & 5.5 & 6.1 & 6.0 & 5.4 \\
\hline 60.0 & 6.1 & 6.5 & 6.9 & 5.7 & 6.1 & 6.1 & 5.9 & 6.5 & 6.6 & 5.9 \\
\hline 75.0 & 6.7 & 6.4 & 6.9 & 6.2 & 6.4 & 5.8 & 6.5 & 6.5 & 7.2 & 5.7 \\
\hline 90.0 & 6.2 & 6.8 & 7.1 & 6.2 & 6.3 & 6.0 & 6.7 & 6.5 & 7.2 & 6.4 \\
\hline 105.0 & 6.5 & 6.7 & 7.3 & 7.2 & 7.0 & 6.1 & 6.8 & 6.8 & 6.7 & 6.7 \\
\hline 120.0 & 6.9 & 7.0 & 8.7 & 6.6 & 6.5 & 6.2 & 7.7 & 6.8 & 7.5 & 6.6 \\
\hline 135.0 & 6.7 & 7.2 & 7.6 & 7.5 & 6.2 & 7.1 & 7.1 & 7.5 & 7.4 & 7.1 \\
\hline 150.0 & 7.9 & 7.4 & 8.3 & 7.2 & 6.9 & 6.8 & 7.9 & 7.9 & 8.7 & 7.4 \\
\hline 165.0 & 8.0 & 7.7 & 9.2 & 7.9 & 6.8 & 7.1 & 8.1 & 7.3 & 9.1 & 7.6 \\
\hline 180.0 & 8.0 & 7.5 & 8.8 & 7.6 & 7.1 & 7.2 & 8.3 & 7.3 & 9.1 & 7.7 \\
\hline 195.0 & 7.8 & 7.7 & 8.9 & 8.0 & 7.6 & 7.3 & 8.3 & 8.3 & 9.1 & 7.8 \\
\hline 210.0 & 8.0 & 8.1 & 9.6 & 7.9 & 7.6 & 7.5 & 8.5 & 8.2 & 9.5 & 7.6 \\
\hline 225.0 & 8.0 & 8.5 & 10.1 & 8.3 & 8.5 & 8.0 & 8.5 & 8.2 & 9.7 & 7.8 \\
\hline 240.0 & 8.7 & 8.9 & 9.2 & 8.3 & 8.5 & 8.2 & 8.9 & 8.9 & 9.0 & 8.3 \\
\hline 255.0 & 9.2 & 10.0 & 10.6 & 8.9 & 9.0 & 8.2 & 10.3 & 9.2 & 11.0 & 9.7 \\
\hline 270.0 & 11.6 & 12.1 & 11.9 & 11.4 & 9.8 & 10.8 & 11.6 & 11.4 & 12.3 & 11.6 \\
\hline
\end{tabular}

$\begin{array}{lllllllllll}\text { AVG } \% & 6.7 & 6.9 & 7.7 & 6.7 & 6.5 & 6.3 & 7.1 & 6.9 & 7.5 & 6.6\end{array}$ $\begin{array}{lllllllllll}\text { WASTE } \% & 8.1 & 8.0 & 9.1 & 7.9 & 7.6 & 7.4 & 8.3 & 8.0 & 9.2 & 7.7\end{array}$ $\begin{array}{lllllllllll}\text { STRG Cm } & 18.5 & 19.0 & 21.1 & 18.3 & 17.8 & 17.3 & 19.4 & 19.0 & 20.7 & 18.1\end{array}$ 
$\begin{array}{lc}\text { DATE: } & 12-20-85 \\ \text { DAY: } & 720\end{array}$

PROBE: $\quad 6031$ STANDARD COUNTS: 8701

\begin{tabular}{|c|c|c|c|c|c|c|c|c|c|c|}
\hline $\begin{array}{l}\text { DEPTH } \\
\text { cm }\end{array}$ & 1 & 2 & 3 & $\begin{array}{l}\text { VOL } \\
4\end{array}$ & $\begin{array}{l}\text { WATER CO } \\
5\end{array}$ & $\begin{array}{c}\text { NTENT, } \\
6\end{array}$ & $\begin{array}{c}\mathrm{cm} / \mathrm{m} \\
7\end{array}$ & 8 & 9 & 10 \\
\hline 30.0 & 9.3 & 9.1 & 9.0 & 9.5 & 8.2 & 8.5 & 7.0 & 8.3 & 8.7 & 8.3 \\
\hline 45.0 & 9.1 & 8.8 & 9.1 & 8.8 & 8.5 & 9.6 & 7.3 & 8.9 & 8.8 & 8.5 \\
\hline 60.0 & 9.8 & 8.3 & 9.0 & 10.0 & 7.2 & 8.5 & 7.7 & 10.4 & 10.2 & 9.3 \\
\hline 75.0 & 7.9 & 8.7 & 10.0 & 10.0 & 6.5 & 7.5 & 7.4 & 9.5 & 10.3 & 8.8 \\
\hline 90.0 & 7.2 & 8.3 & 9.5 & 10.5 & 6.5 & 6.7 & 7.0 & 8.3 & 10.7 & 8.7 \\
\hline 105.0 & 7.4 & 7.8 & 10.0 & 10.7 & 6.7 & 6.3 & 6.5 & 8.0 & 11.1 & 8.3 \\
\hline 120.0 & 7.7 & 6.6 & 10.7 & 9.9 & 6.5 & 6.2 & 6.9 & 7.3 & 11.1 & 7.5 \\
\hline 135.0 & 7.3 & 7.2 & 11.1 & 8.3 & 6.5 & 6.3 & 6.9 & 7.1 & 10.5 & 7.1 \\
\hline 150.0 & 7.4 & 7.4 & 11.0 & 7.6 & 6.6 & 6.5 & 8.2 & 7.2 & 10.2 & 7.6 \\
\hline 165.0 & 8.2 & 7.3 & 11.1 & 8.5 & 6.3 & 7.0 & 7.6 & 7.9 & 9.4 & 8.0 \\
\hline 180.0 & 8.4 & 7.3 & 10.2 & 8.7 & 6.4 & 7.1 & 8.2 & 7.6 & 8.8 & 7.3 \\
\hline 195.0 & 8.4 & 7.4 & 9.7 & 7.9 & 6.5 & 7.8 & 8.1 & 8.1 & 9.1 & 7.5 \\
\hline 210.0 & 7.6 & 8.2 & 9.3 & 8.7 & 7.6 & 7.9 & 7.7 & 8.9 & 10.1 & 7.7 \\
\hline 225.0 & 8.1 & 8.1 & 9.1 & 8.7 & 7.6 & 7.9 & 8.2 & 8.8 & 9.7 & 7.6 \\
\hline 240.0 & 8.6 & 8.8 & 9.3 & 8.9 & 8.2 & 7.9 & 7.8 & 8.8 & 9.7 & 7.8 \\
\hline 255.0 & 9.3 & 9.4 & 9.8 & 10.3 & 8.9 & 8.8 & 9.1 & 9.5 & 10.8 & 9.6 \\
\hline 270.0 & 11.9 & 11.9 & 11.9 & 12.9 & 9.8 & 11.1 & 11.9 & 11.9 & 12.7 & 12.3 \\
\hline$G \%$ & 7.8 & 7.6 & 9.3 & 8.6 & 6.8 & 7.1 & 7.1 & 7.9 & 9.4 & 7.6 \\
\hline NASTE \% & 8.1 & 7.8 & 9.9 & 8.4 & 7.0 & 7.4 & 8.0 & 8.2 & 9.6 & 7.6 \\
\hline RG Cm & 21.3 & 20.8 & 25.5 & 23.8 & 18.6 & 19.5 & 19.7 & 21.8 & 25.8 & 21.0 \\
\hline
\end{tabular}


$\begin{array}{lc}\text { DATE: } & 01-21-86 \\ \text { DAY: } & 757 \\ \text { PROBE: } & 6031\end{array}$

STANDARD COUNTS: 8628

\begin{tabular}{|c|c|c|c|c|c|c|c|c|c|c|}
\hline $\begin{array}{l}\text { DEPTH } \\
\mathrm{cIn}\end{array}$ & 1 & 2 & 3 & $\begin{array}{l}\text { VOL W } \\
4\end{array}$ & $\begin{array}{l}\text { ER C } \\
5\end{array}$ & IENT, & $\begin{array}{l}\mathrm{m} / \mathrm{m} \\
7\end{array}$ & 8 & 9 & 10 \\
\hline 30.0 & 9.9 & 8.9 & 9.5 & 8.3 & 8.8 & 9.2 & 8.5 & 9.2 & 7.5 & 8.5 \\
\hline 45.0 & 11.4 & 10.6 & 10.8 & 9.9 & 11.1 & 11.1 & 10.3 & 10.8 & 11.0 & 10.3 \\
\hline 60.0 & 13.1 & 12.1 & 11.9 & 11.2 & 11.8 & 11.0 & 11.1 & 11.2 & 11.6 & 11.3 \\
\hline 75.0 & 13.2 & 11.9 & 12.5 & 11.7 & 13.3 & 11.5 & 11.6 & 11.1 & 11.8 & 11.2 \\
\hline 90.0 & 13.2 & 11.9 & 12.6 & 11.9 & 13.7 & 11.0 & 11.5 & 11.4 & 12.4 & 11.4 \\
\hline 05.0 & 12.9 & 12.3 & 13.4 & 12.2 & 14.6 & 9.4 & 12.5 & 11.9 & 12.4 & 11.4 \\
\hline 120.0 & 13.2 & 12.1 & 12.8 & 13.0 & 14.2 & 8.1 & 12.3 & 12.0 & 12.6 & 12.2 \\
\hline 135.0 & 12.7 & 12.5 & 12.8 & 12.1 & 13.2 & 7.9 & 13.1 & 11.3 & 12.2 & 12.0 \\
\hline 150.0 & 12.6 & 11.5 & 13.4 & 12.7 & 12.1 & 7.8 & 12.8 & 11.4 & 13.2 & 12.6 \\
\hline 165.0 & 12.9 & 11.5 & 13.7 & 12.4 & 10.1 & 7.5 & 12.5 & 11.2 & 12.6 & 11.8 \\
\hline 180.0 & 13.3 & 11.5 & 12.6 & 12.3 & 7.8 & 8.1 & 12.4 & 11.5 & 12.8 & 11.5 \\
\hline 195.0 & 13.2 & 11.5 & 12.4 & 12.0 & 7.9 & 8.2 & 12.2 & 11.2 & 13.2 & 12.2 \\
\hline 210.0 & 12.2 & 11.7 & 12.4 & 12.3 & 8.3 & 7.9 & 11.5 & 11.3 & 13.5 & 11.6 \\
\hline 225.0 & 12.9 & 11.4 & 12.9 & 10.7 & 7.9 & 7.9 & 10.8 & 9.4 & 11.9 & 12.1 \\
\hline 240.0 & 12.3 & 11.2 & 13.0 & 10.2 & 8.9 & 8.5 & 9.4 & 8.6 & 11.0 & 11.8 \\
\hline 255.0 & 13.9 & 12.6 & 13.1 & 12.2 & 9.3 & 9.9 & 9.6 & 9.1 & 11.3 & 13.2 \\
\hline 270.0 & 15.4 & 13.4 & 14.3 & 13.3 & 10.6 & 11.2 & 12.4 & 11.8 & 12.5 & 13.0 \\
\hline
\end{tabular}

$\begin{array}{lllllllllll}\text { AVG } \% & 11.9 & 10.9 & 11.8 & 10.9 & 10.2 & 8.5 & 10.7 & 10.1 & 11.2 & 10.9\end{array}$ $\begin{array}{lllllllllll}\text { WASTE } \% & 12.8 & 11.5 & 12.9 & 11.8 & 9.0 & 8.0 & 11.7 & 10.6 & 12.6 & 11.9\end{array}$ $\begin{array}{lllllllllll}\text { STRG Cm } & 32.8 & 30.0 & 32.3 & 29.9 & 28.0 & 23.4 & 29.5 & 27.9 & 30.9 & 29.9\end{array}$ 
DATE: $\quad 02-04-86$

DAY: $\quad 766$

PROBE: $\quad 6031$ STANDARD COUNTS: 8673

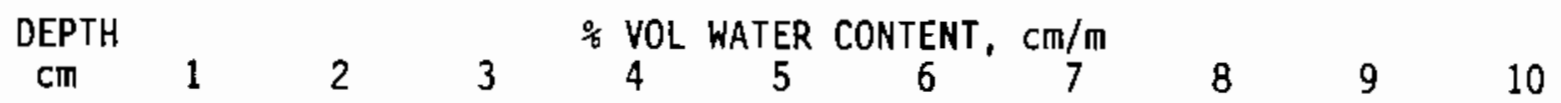

$\begin{array}{lllllllllll}30.0 & 9.8 & 9.6 & 9.3 & 8.9 & 8.9 & 9.1 & 9.2 & 9.5 & 8.3 & 9.6\end{array}$ $\begin{array}{lllllllllll}45.0 & 11.2 & 10.6 & 10.7 & 10.2 & 11.2 & 10.6 & 10.3 & 11.3 & 10.6 & 10.7\end{array}$ $\begin{array}{lllllllllll}60.0 & 12.0 & 10.9 & 10.7 & 10.7 & 12.3 & 10.5 & 10.8 & 11.0 & 11.3 & 11.1\end{array}$ $\begin{array}{lllllllllll}75.0 & 11.8 & 11.6 & 12.0 & 11.4 & 12.0 & 11.0 & 10.9 & 11.2 & 11.4 & 11.0\end{array}$ $\begin{array}{lllllllllll}90.0 & 11.4 & 11.8 & 11.9 & 11.6 & 12.3 & 10.5 & 11.6 & 10.8 & 11.5 & 11.5\end{array}$ $\begin{array}{lllllllllll}105.0 & 10.7 & 11.4 & 12.3 & 12.1 & 13.0 & 9.7 & 10.9 & 10.7 & 11.8 & 11.1\end{array}$ $\begin{array}{lllllllllll}120.0 & 11.1 & 11.7 & 12.7 & 11.6 & 12.5 & 8.6 & 10.9 & 10.8 & 11.5 & 11.1\end{array}$ $\begin{array}{llllllllllll}135.0 & 11.6 & 11.2 & 12.2 & 11.0 & 12.2 & 8.3 & 11.2 & 10.8 & 11.6 & 11.8\end{array}$ $\begin{array}{llllllllllll}150.0 & 12.0 & 12.2 & 12.3 & 11.4 & 11.2 & 8.5 & 11.3 & 10.7 & 12.0 & 11.6\end{array}$ $\begin{array}{lllllllllll}165.0 & 11.5 & 11.3 & 12.7 & 11.3 & 10.6 & 8.6 & 11.8 & 11.2 & 12.3 & 12.2\end{array}$ $\begin{array}{llllllllllll}180.0 & 12.1 & 12.3 & 12.0 & 12.0 & 10.3 & 8.3 & 11.9 & 11.0 & 12.2 & 12.2\end{array}$ $\begin{array}{llllllllllll}195.0 & 11.5 & 11.7 & 11.3 & 11.9 & 10.1 & 7.8 & 11.7 & 12.0 & 12.5 & 11.8\end{array}$ $\begin{array}{lllllllllll}210.0 & 12.0 & 11.4 & 11.9 & 12.4 & 10.4 & 8.1 & 12.2 & 11.3 & 13.2 & 11.9\end{array}$ $\begin{array}{llllllllllll}225.0 & 12.0 & 11.7 & 11.2 & 11.7 & 8.5 & 8.4 & 12.1 & 11.2 & 13.1 & 10.2\end{array}$ $\begin{array}{lllllllllll}240.0 & 11.5 & 12.1 & 11.6 & 12.6 & 9.1 & 8.3 & 12.0 & 11.5 & 11.8 & 11.7\end{array}$ $\begin{array}{lllllllllll}255.0 & 12.9 & 13.2 & 12.2 & 12.7 & 9.4 & 9.8 & 12.4 & 11.6 & 13.0 & 13.0\end{array}$ $\begin{array}{lllllllllll}270.0 & 14.9 & 13.6 & 13.8 & 13.7 & 12.2 & 13.0 & 14.1 & 13.2 & 13.3 & 13.6\end{array}$

$\begin{array}{lllllllllll}\text { AVG : } & 10.9 & 10.9 & 11.0 & 10.8 & 10.2 & 8.6 & 10.7 & 10.4 & 11.1 & 10.7\end{array}$ $\begin{array}{lllllllllll}\text { WASTE } \% & 11.8 & 11.8 & 11.9 & 11.9 & 10.0 & 8.3 & 11.9 & 11.3 & 12.4 & 11.7\end{array}$ $\begin{array}{lllllllllll}\text { STRG } \mathrm{cm} & 30.0 & 29.9 & 30.2 & 29.7 & 28.1 & 23.6 & 29.3 & 28.5 & 30.4 & 29.5\end{array}$ 
DATE: $\quad 02-19-86$

PROBE: $\quad 6031$ STANDARD COUNTS: 8709

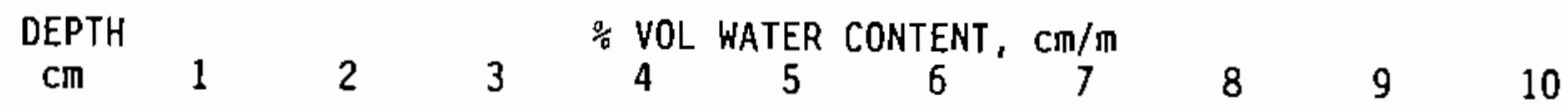

$\begin{array}{lllllllllll}30.0 & 8.9 & 9.4 & 8.8 & 9.1 & 8.5 & 8.5 & 8.9 & 9.7 & 8.1 & 8.5\end{array}$ $\begin{array}{lllllllllll}45.0 & 10.4 & 11.1 & 10.3 & 11.1 & 10.5 & 10.4 & 10.3 & 10.7 & 10.3 & 10.2\end{array}$ $\begin{array}{lllllllllll}60.0 & 11.4 & 11.5 & 10.4 & 10.3 & 10.9 & 10.3 & 10.5 & 10.3 & 11.3 & 11.4\end{array}$ $\begin{array}{lllllllllll}75.0 & 10.9 & 10.7 & 9.8 & 10.5 & 10.6 & 11.1 & 10.4 & 10.1 & 11.7 & 11.1\end{array}$ $\begin{array}{lllllllllll}90.0 & 10.2 & 10.2 & 10.4 & 10.3 & 10.8 & 10.9 & 9.9 & 9.8 & 11.4 & 11.4\end{array}$ $\begin{array}{llllllllllll}105.0 & 10.3 & 10.2 & 10.9 & 10.1 & 11.1 & 9.8 & 10.4 & 9.9 & 10.8 & 11.4\end{array}$ $\begin{array}{lllllllllll}120.0 & 10.0 & 10.1 & 11.6 & 9.8 & 11.1 & 9.2 & 10.0 & 9.4 & 11.1 & 11.1\end{array}$ $\begin{array}{llllllllllll}135.0 & 10.3 & 9.9 & 10.7 & 9.7 & 10.8 & 9.1 & 10.1 & 9.8 & 10.9 & 11.7\end{array}$ $\begin{array}{lllllllllll}150.0 & 10.0 & 10.4 & 12.0 & 10.4 & 9.9 & 9.2 & 10.8 & 9.6 & 11.7 & 10.5\end{array}$ $\begin{array}{llllllllllll}165.0 & 10.7 & 10.9 & 11.3 & 10.6 & 10.3 & 8.7 & 10.5 & 10.7 & 11.9 & 10.9\end{array}$ $\begin{array}{lllllllllll}180.0 & 10.4 & 10.8 & 11.3 & 11.4 & 9.9 & 8.7 & 11.3 & 10.8 & 11.2 & 10.2\end{array}$ $\begin{array}{lllllllllll}195.0 & 10.4 & 11.6 & 11.9 & 11.2 & 10.7 & 8.6 & 11.6 & 11.2 & 12.7 & 10.9\end{array}$ $\begin{array}{lllllllllll}210.0 & 11.1 & 11.3 & 12.6 & 11.5 & 10.2 & 8.7 & 11.5 & 11.0 & 12.3 & 10.9\end{array}$ $\begin{array}{lllllllllll}225.0 & 11.6 & 11.5 & 11.6 & 11.8 & 10.4 & 8.8 & 11.9 & 12.6 & 12.2 & 10.4\end{array}$ $\begin{array}{lllllllllll}240.0 & 10.8 & 12.1 & 12.6 & 11.9 & 11.0 & 8.1 & 12.5 & 11.8 & 12.8 & 11.1\end{array}$ $\begin{array}{llllllllllll}255.0 & 11.2 & 12.9 & 13.2 & 13.1 & 11.1 & 10.2 & 13.2 & 12.3 & 12.9 & 11.5\end{array}$ $\begin{array}{lllllllllll}270.0 & 14.6 & 13.6 & 14.1 & 15.8 & 13.1 & 14.3 & 15.2 & 15.3 & 14.9 & 14.5\end{array}$

$\begin{array}{lllllllllll}\text { AVG \% } & 9.9 & 10.3 & 10.5 & 10.2 & 9.9 & 8.8 & 10.2 & 10.0 & 10.8 & 10.2\end{array}$ $\begin{array}{lllllllllll}\text { WASTE } \% & 10.7 & 11.2 & 11.9 & 11.3 & 10.3 & 8.7 & 11.4 & 11.1 & 12.1 & 10.7\end{array}$ $\begin{array}{lllllllllll}\text { STRG Cm } & 27.3 & 28.2 & 29.0 & 27.9 & 27.1 & 24.3 & 28.1 & 27.5 & 29.7 & 28.0\end{array}$ 


\begin{tabular}{|c|c|c|c|c|c|c|c|c|c|c|}
\hline $\begin{array}{l}\text { DATE: } \\
\text { DAY: } \\
\text { PROBE : }\end{array}$ & $\begin{array}{r}03-0 \\
79 \\
60\end{array}$ & & STANDARD & COUNTS & 86 & & & & & \\
\hline $\begin{array}{l}\text { DEPTH } \\
\mathrm{cm}\end{array}$ & 1 & 2 & 3 & $\begin{array}{l}\text { VOL Wf } \\
4\end{array}$ & $\begin{array}{c}\text { ATER CO } \\
5\end{array}$ & $\begin{array}{l}\text { ITENT, } \\
6\end{array}$ & $\mathrm{~cm} / \mathrm{m}$ & 8 & 9 & 10 \\
\hline 30.0 & 6.6 & 6.8 & 6.9 & 7.5 & 7.0 & 7.4 & 7.1 & 7.4 & 6.6 & 6.7 \\
\hline 45.0 & 8.9 & 9.3 & 9.9 & 9.0 & 9.6 & 9.3 & 9.1 & 9.1 & 9.2 & 8.7 \\
\hline 60.0 & 10.5 & 10.6 & 10.6 & 9.5 & 10.7 & 9.3 & 10.4 & 9.9 & 9.9 & 9.9 \\
\hline 75.0 & 11.8 & 10.4 & 11.7 & 10.7 & 11.1 & 9.7 & 10.5 & 9.8 & 10.2 & 9.4 \\
\hline 90.0 & 10.9 & 10.7 & 10.8 & 10.8 & 11.6 & 10.1 & 10.7 & 9.6 & 10.9 & 10.3 \\
\hline 105.0 & 10.2 & 10.4 & 11.5 & 10.9 & 12.2 & 9.6 & 10.3 & 10.4 & 11.1 & 9.9 \\
\hline 120.0 & 10.3 & 10.8 & 11.8 & 11.0 & 11.6 & 8.6 & 10.6 & 10.2 & 10.6 & 10.4 \\
\hline 135.0 & 10.4 & 11.3 & 11.8 & 10.9 & 11.0 & 9.6 & 10.8 & 10.5 & 11.2 & 10.9 \\
\hline 150.0 & 10.7 & 11.5 & 11.9 & 11.6 & 10.6 & 9.5 & 11.5 & 10.0 & 11.4 & 10.6 \\
\hline 165.0 & 11.1 & 10.4 & 12.2 & 11.4 & 10.3 & 9.1 & 11.1 & 10.4 & 12.1 & 11.2 \\
\hline 180.0 & 11.8 & 11.2 & 12.0 & 11.5 & 9.9 & 9.2 & 11.2 & 11.2 & 12.1 & 11.3 \\
\hline 195.0 & 11.0 & 11.3 & 12.2 & 11.6 & 10.8 & 8.7 & 12.3 & 11.9 & 12.9 & 11.6 \\
\hline 210.0 & 11.5 & 11.8 & 11.7 & 12.4 & 11.2 & 9.1 & 12.4 & 12.1 & 13.2 & 11.8 \\
\hline 225.0 & 11.4 & 11.2 & 12.1 & 12.5 & 11.3 & 9.7 & 12.7 & 11.9 & 12.3 & 11.6 \\
\hline 240.0 & 11.9 & 11.8 & 11.9 & 12.5 & 11.4 & 10.0 & 12.6 & 11.8 & 12.8 & 11.9 \\
\hline 255.0 & 12.2 & 12.4 & 12.9 & 13.5 & 11.4 & 11.0 & 14.1 & 12.3 & 14.1 & 13.1 \\
\hline 270.0 & 13.9 & 13.9 & 13.8 & 16.5 & 13.5 & 15.9 & 16.9 & 16.2 & 16.3 & 17.2 \\
\hline
\end{tabular}

$\begin{array}{lllllllllll}\text { AVG } \% & 10.1 & 10.1 & 10.7 & 10.4 & 10.1 & 8.8 & 10.4 & 9.9 & 10.6 & 10.0\end{array}$ $\begin{array}{lllllllllll}\text { WASTE \% } & 11.3 & 11.3 & 12.0 & 11.9 & 10.8 & 9.3 & 12.0 & 11.3 & 12.4 & 11.4\end{array}$ $\begin{array}{lllllllllll}\text { STRG cm } & 27.7 & 27.8 & 29.4 & 28.7 & 27.8 & 24.3 & 28.7 & 27.3 & 29.2 & 27.4\end{array}$ 


\section{DATE: $\quad 03-20-86$ \\ $\begin{array}{lll}\text { DAY: } & 810 \\ \text { PROBE: } & 6031 \quad \text { STANDARD COUNTS: } 8426\end{array}$}

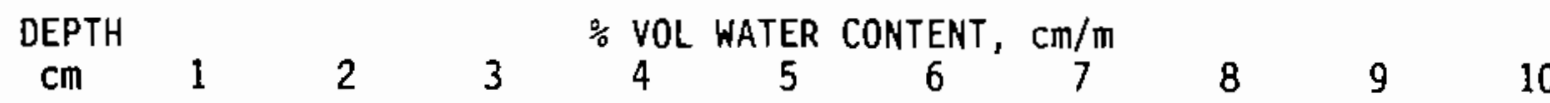

$\begin{array}{lllllllllll}30.0 & 8.4 & 8.7 & 9.0 & 8.1 & 8.2 & 8.7 & 8.4 & 8.6 & 8.1 & 7.9\end{array}$ $\begin{array}{lllllllllll}45.0 & 9.8 & 9.9 & 9.8 & 10.2 & 9.9 & 10.5 & 10.2 & 10.7 & 9.9 & 10.1\end{array}$ $\begin{array}{lllllllllll}60.0 & 11.8 & 11.2 & 10.9 & 9.7 & 11.1 & 9.7 & 10.2 & 10.8 & 10.9 & 9.8\end{array}$ $\begin{array}{lllllllllll}75.0 & 10.6 & 10.4 & 11.4 & 11.1 & 10.9 & 10.8 & 10.4 & 10.4 & 10.4 & 10.1\end{array}$ $\begin{array}{lllllllllll}90.0 & 10.7 & 11.0 & 11.2 & 10.0 & 11.3 & 10.7 & 10.5 & 9.9 & 10.7 & 9.8\end{array}$ $\begin{array}{lllllllllll}105.0 & 10.2 & 10.5 & 10.8 & 10.9 & 11.6 & 8.9 & 10.4 & 9.6 & 10.8 & 9.8\end{array}$ $\begin{array}{lllllllllll}120.0 & 10.0 & 10.4 & 10.6 & 10.5 & 10.7 & 9.2 & 10.7 & 9.9 & 10.0 & 9.7\end{array}$ $\begin{array}{lllllllllll}135.0 & 10.4 & 9.6 & 10.9 & 9.9 & 11.0 & 9.3 & 10.9 & 9.8 & 10.8 & 10.0\end{array}$ $\begin{array}{lllllllllll}150.0 & 10.6 & 11.1 & 11.0 & 10.5 & 10.1 & 9.7 & 10.3 & 10.6 & 11.7 & 10.7\end{array}$ $\begin{array}{lllllllllll}165.0 & 11.5 & 11.2 & 11.5 & 11.3 & 9.9 & 9.9 & 10.9 & 10.7 & 12.3 & 10.4\end{array}$ $\begin{array}{lllllllllll}180.0 & 11.2 & 11.4 & 11.6 & 11.2 & 10.0 & 9.1 & 11.2 & 11.1 & 11.8 & 10.7\end{array}$ $\begin{array}{lllllllllll}195.0 & 11.8 & 11.5 & 11.2 & 11.6 & 10.6 & 9.8 & 11.9 & 12.3 & 12.2 & 11.8\end{array}$ $\begin{array}{lllllllllll}210.0 & 11.9 & 12.4 & 12.4 & 12.2 & 10.0 & 10.1 & 12.0 & 12.9 & 13.7 & 11.2\end{array}$ $\begin{array}{lllllllllll}225.0 & 11.9 & 11.7 & 12.2 & 11.9 & 11.1 & 10.3 & 11.8 & 12.8 & 12.0 & 11.5\end{array}$ $\begin{array}{lllllllllll}240.0 & 11.7 & 12.1 & 12.7 & 12.8 & 10.9 & 9.7 & 11.3 & 12.7 & 12.8 & 11.7\end{array}$ $\begin{array}{lllllllllll}255.0 & 13.6 & 13.0 & 13.6 & 13.8 & 12.0 & 11.4 & 12.2 & 14.0 & 14.1 & 14.6\end{array}$ $\begin{array}{lllllllllll}270.0 & 15.8 & 14.9 & 15.7 & 16.2 & 13.4 & 14.3 & 13.6 & 18.7 & 19.7 & 23.2\end{array}$

$\begin{array}{lllllllllll}\text { AVG } \% & 10.4 & 10.4 & 10.6 & 10.3 & 10.0 & 9.3 & 10.2 & 10.4 & 10.7 & 10.0\end{array}$ $\begin{array}{lllllllllll}\text { WASTE \% } & 11.5 & 11.6 & 11.8 & 11.6 & 10.4 & 9.8 & 11.4 & 11.9 & 12.3 & 11.1\end{array}$ $\begin{array}{lllllllllll}\text { STRG } \mathrm{cm} & 28.5 & 28.5 & 29.2 & 28.4 & 27.4 & 25.5 & 28.0 & 28.6 & 29.5 & 27.5\end{array}$ 


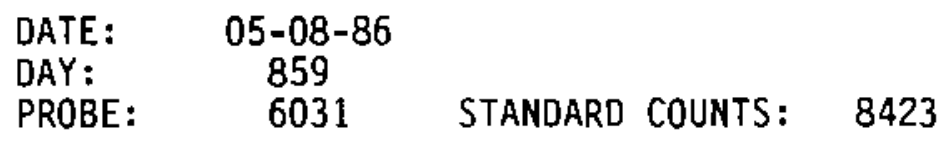

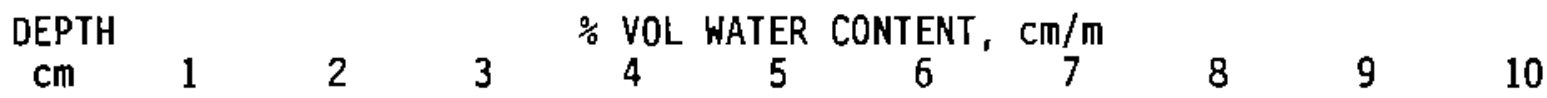

$\begin{array}{lllllllllll}30.0 & 5.9 & 5.3 & 5.9 & 5.5 & 5.5 & 6.2 & 5.6 & 6.1 & 5.5 & 4.6\end{array}$ $\begin{array}{lllllllllll}45.0 & 8.4 & 8.6 & 8.2 & 7.8 & 7.7 & 7.5 & 8.0 & 8.0 & 7.7 & 8.4\end{array}$ $\begin{array}{lllllllllll}60.0 & 9.8 & 9.5 & 10.1 & 9.3 & 9.1 & 8.9 & 8.9 & 8.9 & 8.9 & 9.3\end{array}$

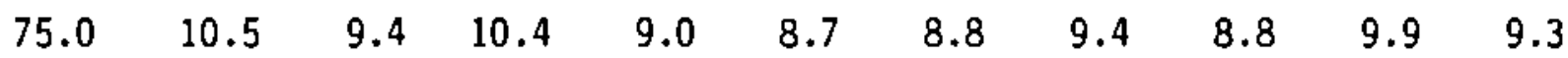

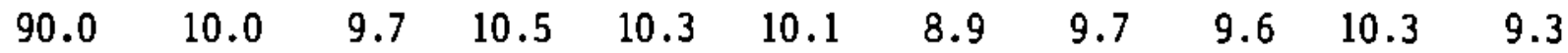

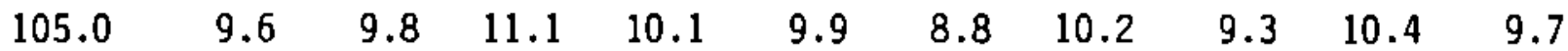

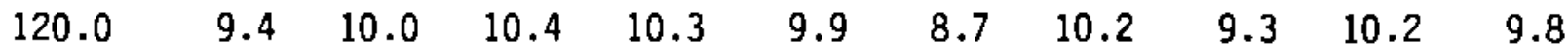

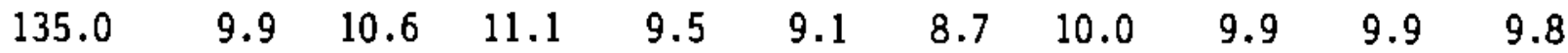

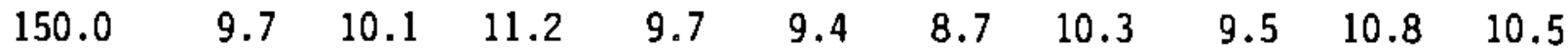

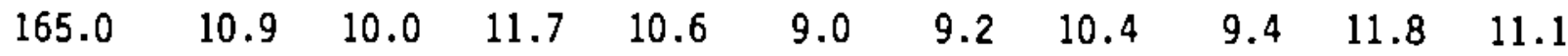

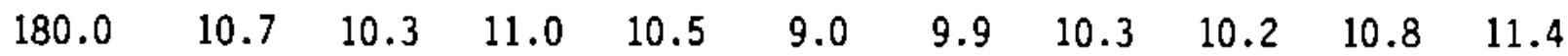

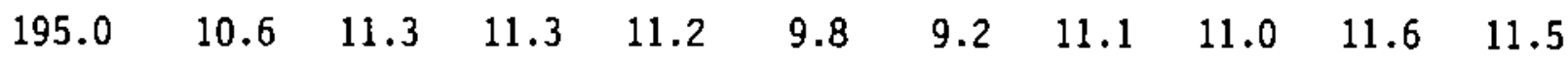

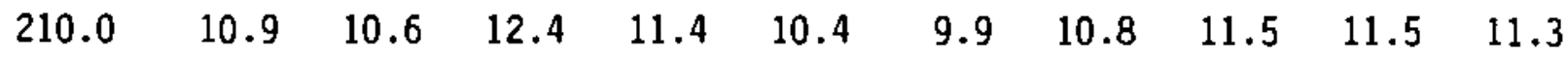

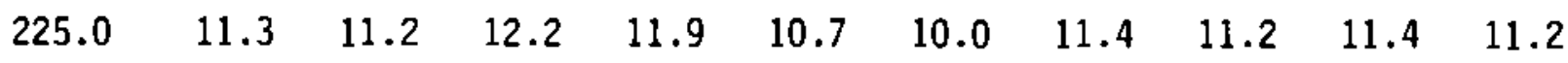

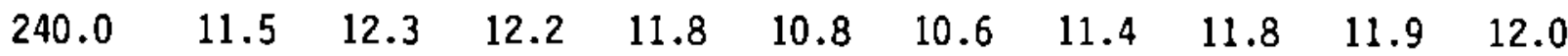

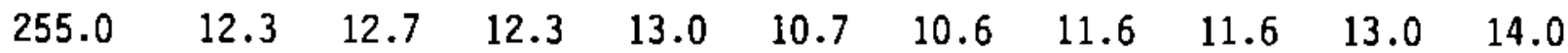

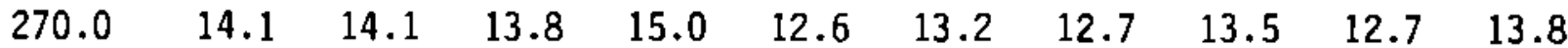

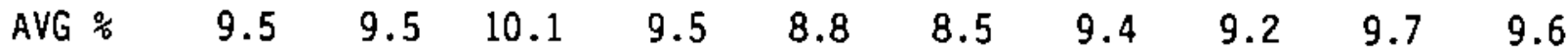

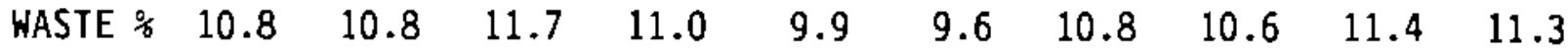

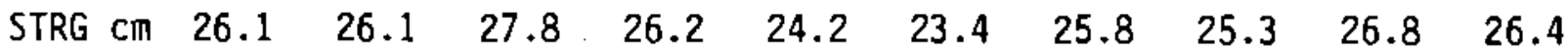


DATE: $\quad 05-23-86$

PROBE: $\quad 6031$ STANDARD COUNTS: 8392

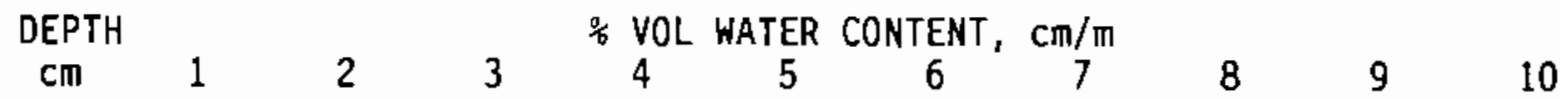

$\begin{array}{lllllllllll}30.0 & 5.1 & 5.8 & 5.3 & 5.7 & 5.1 & 5.7 & 5.8 & 6.0 & 5.4 & 5.2\end{array}$ $\begin{array}{lllllllllll}45.0 & 7.5 & 8.2 & 8.7 & 7.4 & 7.1 & 7.5 & 8.0 & 7.8 & 7.3 & 7.9\end{array}$ $\begin{array}{lllllllllll}60.0 & 10.3 & 9.2 & 9.8 & 9.2 & 8.3 & 8.2 & 9.2 & 8.6 & 9.1 & 9.0\end{array}$ $\begin{array}{lllllllllll}75.0 & 9.8 & 9.6 & 9.8 & 8.9 & 8.7 & 8.5 & 9.3 & 9.2 & 10.1 & 8.8\end{array}$ $\begin{array}{lllllllllll}90.0 & 9.3 & 9.2 & 10.2 & 9.5 & 9.8 & 8.9 & 9.7 & 9.5 & 9.9 & 9.3\end{array}$ $\begin{array}{lllllllllll}105.0 & 9.0 & 9.4 & 10.5 & 9.5 & 10.4 & 8.5 & 9.3 & 9.3 & 10.4 & 9.0\end{array}$ $\begin{array}{lllllllllll}120.0 & 9.2 & 9.6 & 10.4 & 9.4 & 9.4 & 8.4 & 10.3 & 9.6 & 10.2 & 9.5\end{array}$ $\begin{array}{lllllllllll}135.0 & 8.9 & 9.4 & 10.4 & 9.4 & 8.6 & 8.6 & 10.0 & 8.7 & 9.9 & 10.0\end{array}$ $\begin{array}{lllllllllll}150.0 & 9.7 & 9.7 & 11.2 & 9.5 & 8.9 & 9.2 & 9.7 & 9.3 & 10.5 & 10.5\end{array}$ $\begin{array}{lllllllllll}165.0 & 9.9 & 10.3 & 11.4 & 10.4 & 9.3 & 8.9 & 9.9 & 9.9 & 11.1 & 10.8\end{array}$ $\begin{array}{lllllllllll}180.0 & 10.3 & 11.1 & 10.6 & 10.3 & 9.5 & 8.9 & 10.3 & 9.4 & 11.4 & 10.8\end{array}$ $\begin{array}{lllllllllll}195.0 & 10.0 & 10.9 & 11.1 & 10.8 & 10.4 & 9.9 & 11.2 & 10.6 & 11.8 & 11.5\end{array}$ $\begin{array}{lllllllllll}210.0 & 10.3 & 10.7 & 11.5 & 10.6 & 10.5 & 10.4 & 11.6 & 11.1 & 11.9 & 10.9\end{array}$ $\begin{array}{lllllllllll}225.0 & 10.5 & 10.6 & 11.6 & 11.0 & 10.4 & 10.1 & 11.1 & 11.8 & 11.9 & 11.3\end{array}$ $\begin{array}{lllllllllll}240.0 & 11.2 & 11.5 & 11.7 & 11.1 & 10.5 & 9.6 & 11.2 & 11.6 & 12.3 & 11.4\end{array}$ $\begin{array}{lllllllllll}255.0 & 11.7 & 12.5 & 13.7 & 12.4 & 11.8 & 10.8 & 12.1 & 11.9 & 12.7 & 13.1\end{array}$ $\begin{array}{lllllllllll}270.0 & 13.5 & 13.6 & 14.5 & 15.0 & 12.9 & 12.7 & 12.9 & 13.6 & 13.3 & 14.7\end{array}$

$\begin{array}{lllllllllll}\text { AVG } \% & 9.0 & 9.3 & 9.9 & 9.1 & 8.7 & 8.4 & 9.3 & 9.1 & 9.8 & 9.4\end{array}$

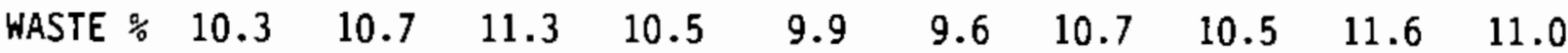
$\begin{array}{lllllllllll}\text { STRG Cm } & 24.7 & 25.5 & 27.2 & 25.1 & 24.1 & 23.0 & 25.7 & 25.0 & 26.8 & 25.7\end{array}$ 


\begin{tabular}{|c|c|c|c|c|c|c|c|c|c|c|}
\hline $\begin{array}{l}\text { DATE: } \\
\text { DAY: } \\
\text { PROBE: }\end{array}$ & $\begin{array}{r}06-0 \\
89 \\
60\end{array}$ & & STANDARD & D COUNT & & 8510 & & & & \\
\hline $\begin{array}{l}\text { DEPTH } \\
\mathrm{cm}\end{array}$ & 1 & 2 & 3 & $\% \underset{4}{\text { VOL W }}$ & $\begin{array}{l}\text { IATER Cl } \\
5\end{array}$ & $\begin{array}{c}\text { CONTENT, } \\
6\end{array}$ & $\begin{array}{c}\mathrm{cm} / \mathrm{m} \\
7\end{array}$ & 8 & 9 & 10 \\
\hline 30.0 & 4.2 & 5.2 & 4.8 & 4.7 & 4.7 & 5.0 & 4.7 & 5.4 & 4.0 & 4.5 \\
\hline 45.0 & 7.9 & 8.3 & 7.6 & 7.2 & 7.4 & 6.9 & 7.1 & 6.9 & 7.2 & 7.7 \\
\hline 60.0 & 9.0 & 9.2 & 8.9 & 8.6 & 8.7 & 7.4 & 8.2 & 8.1 & 8.3 & 9.2 \\
\hline 75.0 & 8.8 & 9.1 & 9.5 & 9.2 & 8.2 & 7.8 & 9.2 & 8.8 & 8.9 & 9.5 \\
\hline 90.0 & 8.7 & 8.9 & 10.1 & 9.4 & 9.6 & 8.6 & 9.4 & 8.8 & 9.3 & 8.8 \\
\hline 105.0 & 8.5 & 8.5 & 10.2 & 8.9 & 10.5 & 8.2 & 8.6 & 8.6 & 9.7 & 9.0 \\
\hline 120.0 & 8.6 & 9.4 & 9.9 & 9.9 & 9.0 & 7.6 & 9.0 & 9.4 & 9.7 & 9.5 \\
\hline 135.0 & 8.7 & 9.5 & 10.6 & 9.1 & 8.5 & 7.8 & 8.9 & 8.7 & 9.8 & 9.1 \\
\hline 150.0 & 9.0 & 9.8 & 10.1 & 9.4 & 8.8 & 8.3 & 9.3 & 9.4 & 10.1 & 9.4 \\
\hline 165.0 & 9.6 & 10.0 & 9.8 & 9.5 & 8.2 & 8.3 & 9.6 & 9.1 & 10.7 & 9.6 \\
\hline 180.0 & 9.6 & 9.8 & 10.5 & 10.2 & 8.7 & 8.4 & 9.9 & 9.0 & 10.4 & 9.8 \\
\hline 195.0 & 10.0 & 10.1 & 10.7 & 10.2 & 9.8 & 8.6 & 10.7 & 9.7 & 10.8 & 9.9 \\
\hline 210.0 & 9.8 & 11.0 & 10.8 & 10.7 & 9.9 & 9.8 & 10.5 & 11.0 & 11.7 & 9.4 \\
\hline 225.0 & 10.5 & 10.5 & 11.2 & 10.6 & 10.7 & 9.8 & 10.0 & 10.9 & 10.7 & 9.8 \\
\hline 240.0 & 9.9 & 11.0 & 11.7 & 11.1 & 10.6 & 10.0 & 9.8 & 11.2 & 11.1 & 10.1 \\
\hline 255.0 & 12.2 & 11.6 & 11.7 & 11.9 & 10.9 & 10.4 & 11.4 & 10.9 & 11.9 & 11.2 \\
\hline 270.0 & 14.5 & 12.8 & 13.3 & 14.4 & 12.5 & 12.0 & 12.1 & 13.2 & 13.2 & 12.6 \\
\hline
\end{tabular}

$\begin{array}{lllllllllll}\text { AVG \% } & 8.5 & 8.9 & 9.3 & 8.9 & 8.5 & 7.8 & 8.6 & 8.6 & 9.1 & 8.6\end{array}$ $\begin{array}{lllllllllll}\text { WASTE \% } & 9.8 & 10.3 & 10.7 & 10.2 & 9.5 & 9.0 & 10.0 & 10.0 & 10.8 & 9.7\end{array}$ $\begin{array}{llllllllllll}\text { STRG CM } & 23.5 & 24.6 & 25.6 & 24.4 & 23.4 & 21.5 & 23.7 & 23.6 & 25.0 & 23.7\end{array}$ 
DATE: $\quad 06-26-86$

PROBE: $\quad 6031$ STANDARD COUNTS: 8529

\begin{tabular}{|c|c|c|c|c|c|c|c|c|c|c|}
\hline $\begin{array}{l}\text { DEPTH } \\
\text { CII }\end{array}$ & 1 & 2 & 3 & $\begin{array}{l}\text { VOL } \\
4\end{array}$ & $\begin{array}{l}\text { NATER CO } \\
5\end{array}$ & $\begin{array}{l}\text { TENT, } \\
6\end{array}$ & $\begin{array}{c}\mathrm{cm} / \mathrm{m} \\
7\end{array}$ & 8 & 9 & 10 \\
\hline 30.0 & 4.2 & 4.4 & 3.9 & 4.0 & 3.9 & 4.1 & 3.9 & 4.9 & 3.2 & 3.9 \\
\hline 45.0 & 6.8 & 7.3 & 7.0 & 6.5 & 6.5 & 6.4 & 7.1 & 6.8 & 6.5 & 6.5 \\
\hline 60.0 & 9.0 & 8.4 & 8.2 & 8.5 & 7.4 & 6.6 & 8.4 & 8.4 & 7.9 & 9.3 \\
\hline 75.0 & 9.1 & 8.4 & 8.7 & 8.5 & 7.4 & 7.5 & 8.9 & 8.2 & 8.6 & 9.0 \\
\hline 90.0 & 8.3 & 9.6 & 8.9 & 9.2 & 8.3 & 7.8 & 9.2 & 8.8 & 9.0 & 8.8 \\
\hline 105.0 & 8.5 & 9.1 & 9.6 & 9.3 & 8.2 & 7.7 & 9.3 & 8.3 & 9.2 & 8.5 \\
\hline 120.0 & 8.7 & 9.3 & 9.7 & 9.2 & 8.3 & 7.6 & 9.3 & 9.0 & 9.2 & 9.1 \\
\hline 135.0 & 8.8 & 9.0 & 9.7 & 8.8 & 8.4 & 7.6 & 9.3 & 8.5 & 9.0 & 8.8 \\
\hline 150.0 & 8.7 & 9.4 & 9.6 & 9.1 & 8.5 & 8.6 & 9.0 & 8.7 & 9.5 & 9.2 \\
\hline 165.0 & 9.7 & 9.2 & 10.5 & 9.7 & 8.3 & 8.1 & 9.6 & 9.2 & 10.7 & 9.4 \\
\hline 180.0 & 9.5 & 10.0 & 9.8 & 9.7 & 8.5 & 8.2 & 9.6 & 8.9 & 10.3 & 9.9 \\
\hline 195.0 & 9.4 & 10.0 & 10.0 & 9.7 & 9.4 & 9.0 & 9.6 & 10.0 & 10.8 & 9.2 \\
\hline 210.0 & 9.9 & 10.0 & 10.5 & 10.0 & 10.1 & 9.3 & 10.3 & 10.5 & 10.8 & 9.5 \\
\hline 225.0 & 9.7 & 10.4 & 10.7 & 10.1 & 9.7 & 9.4 & 10.5 & 10.0 & 10.8 & 9.7 \\
\hline 240.0 & 10.2 & 10.6 & 11.6 & 10.7 & 10.1 & 9.6 & 10.2 & 10.7 & 10.7 & 10.1 \\
\hline 255.0 & 11.2 & 11.3 & 11.3 & 11.5 & 10.6 & 10.7 & 10.4 & 10.8 & 11.8 & 11.4 \\
\hline 270.0 & 13.3 & 12.7 & 12.8 & 14.1 & 12.2 & 11.9 & 11.9 & 13.6 & 12.5 & 12.4 \\
\hline AVG \% & 8.3 & 8.6 & 8.8 & 8.5 & 7.9 & 7.5 & 8.5 & 8.3 & 8.7 & 8.4 \\
\hline WASTE \% & 9.6 & 9.9 & 10.4 & 9.9 & 9.2 & 8.9 & 9.8 & 9.7 & 10.5 & 9.6 \\
\hline STRG cm & 22.9 & 23.7 & 24.2 & 23.4 & 21.6 & 20.7 & 23.4 & 22.9 & 23.9 & 23.0 \\
\hline
\end{tabular}


$\begin{array}{lcl}\text { DATE: } & 07-11-86 & \\ \text { DAY: } & 923 & \\ \text { PROBE: } & 6031 & \text { STANDARD COUNTS: } \quad 8720\end{array}$

\begin{tabular}{|c|c|c|c|c|c|c|c|c|c|c|}
\hline $\begin{array}{l}\text { DEPTH } \\
\text { cm }\end{array}$ & 1 & 2 & 3 & $\begin{array}{l}\text { VOL W } \\
4\end{array}$ & $\begin{array}{l}\text { TER CO } \\
5\end{array}$ & $\begin{array}{l}\text { ENT, } \\
6\end{array}$ & $\begin{array}{c}\mathrm{c} m / \mathrm{m} \\
7\end{array}$ & 8 & 9 & 10 \\
\hline 30.0 & 3.5 & 4.3 & 3.6 & 4.8 & 4.4 & 5.2 & 4.0 & 4.1 & 3.3 & 4.0 \\
\hline 45.0 & 6.0 & 6.4 & 6.2 & 6.5 & 6.1 & 6.4 & 6.2 & 5.8 & 6.4 & 6.3 \\
\hline 60.0 & 7.9 & 8.1 & 8.0 & 8.3 & 6.7 & 7.4 & 7.9 & 7.6 & 7.6 & 6.9 \\
\hline 75.0 & 7.9 & 8.0 & 8.2 & 8.1 & 7.2 & 7.6 & 8.0 & 8.0 & 8.2 & 7.4 \\
\hline 90.0 & 7.9 & 8.2 & 8.5 & 8.3 & 8.1 & 7.5 & 7.8 & 7.7 & 8.4 & 7.5 \\
\hline 105.0 & 7.7 & 8.7 & 9.3 & 8.3 & 8.1 & 6.8 & 8.4 & 8.0 & 8.0 & 8.1 \\
\hline 120.0 & 8.1 & 7.9 & 9.5 & 9.2 & 7.7 & 8.2 & 8.7 & 7.8 & 8.4 & 8.0 \\
\hline 135.0 & 7.8 & 8.4 & 9.5 & 9.0 & 7.5 & 8.0 & 9.2 & 8.8 & 7.3 & 8.5 \\
\hline 150.0 & 8.0 & 8.9 & 9.2 & 9.0 & 7.4 & 9.1 & 8.7 & 8.6 & 9.0 & 9.1 \\
\hline 165.0 & 8.8 & 9.1 & 9.4 & 9.2 & 8.1 & 8.1 & 9.1 & 8.4 & 9.8 & 8.4 \\
\hline 180.0 & 9.4 & 9.1 & 9.5 & 9.9 & 8.0 & 8.7 & 9.2 & 9.0 & 9.4 & 8.8 \\
\hline 195.0 & 9.5 & 8.9 & 9.6 & 9.3 & 8.8 & 9.3 & 9.4 & 9.6 & 10.0 & 8.8 \\
\hline 210.0 & 9.0 & 9.3 & 10.0 & 10.0 & 9.2 & 9.4 & 9.7 & 10.3 & 10.3 & 9.0 \\
\hline 225.0 & 8.8 & 9.6 & 10.1 & 10.5 & 9.7 & 9.8 & 10.0 & 9.7 & 10.1 & 8.6 \\
\hline 240.0 & 8.7 & 10.0 & 9.6 & 10.3 & 10.0 & 10.4 & 8.8 & 10.3 & 10.6 & 9.2 \\
\hline 255.0 & 9.8 & 10.5 & 10.4 & 12.0 & 9.6 & 10.8 & 10.5 & 10.7 & 11.4 & 10.3 \\
\hline 270.0 & 13.0 & 12.3 & 12.8 & 15.0 & 11.6 & 12.5 & 12.0 & 13.1 & 11.9 & 12.6 \\
\hline
\end{tabular}

$\begin{array}{lllllllllll}\text { AVG \% } & 7.6 & 8.0 & 8.3 & 8.4 & 7.4 & 7.8 & 8.0 & 7.9 & 8.1 & 7.6\end{array}$ $\begin{array}{lllllllllll}\text { WASTE \% } & 8.9 & 9.3 & 9.6 & 9.7 & 8.7 & 9.3 & 9.3 & 9.4 & 9.9 & 8.9\end{array}$ $\begin{array}{lllllllllll}\text { STRG Cm } & 20.8 & 21.9 & 22.8 & 23.1 & 20.5 & 21.5 & 21.9 & 21.7 & 22.3 & 20.9\end{array}$ 
$\begin{array}{lcl}\text { DATE: } & 07-28-86 & \\ \text { DAY: } & 923 & \\ \text { PROBE: } & 6031 & \text { STANDARD COUNTS: } \quad 8720\end{array}$

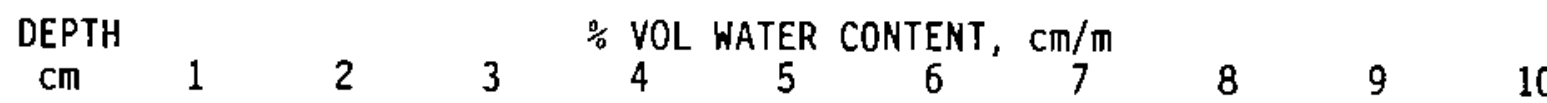

$\begin{array}{lllllllllll}30.0 & 3.2 & 3.9 & 3.5 & 3.3 & 3.4 & 4.6 & 4.2 & 4.2 & 3.0 & 3.4\end{array}$

$\begin{array}{lllllllllll}45.0 & 6.7 & 6.2 & 6.9 & 5.8 & 5.6 & 6.5 & 5.7 & 6.1 & 6.1 & 6.9\end{array}$

$\begin{array}{lllllllllll}60.0 & 7.7 & 7.6 & 8.2 & 7.4 & 6.5 & 6.8 & 7.5 & 6.9 & 7.8 & 7.8\end{array}$

$\begin{array}{lllllllllll}75.0 & 8.6 & 8.2 & 7.9 & 7.7 & 6.0 & 7.4 & 7.6 & 7.6 & 8.2 & 7.6\end{array}$

$\begin{array}{lllllllllll}90.0 & 7.3 & 8.5 & 8.7 & 8.2 & 7.2 & 7.3 & 8.1 & 7.5 & 8.2 & 7.5\end{array}$

$\begin{array}{lllllllllll}105.0 & 7.4 & 8.1 & 9.3 & 8.3 & 7.5 & 7.6 & 8.5 & 7.8 & 8.4 & 8.1\end{array}$

$\begin{array}{lllllllllll}120.0 & 7.9 & 8.0 & 9.3 & 8.6 & 7.1 & 6.9 & 8.6 & 7.9 & 8.3 & 8.7\end{array}$

$\begin{array}{lllllllllll}135.0 & 7.9 & 8.5 & 9.2 & 8.1 & 7.6 & 7.7 & 8.3 & 8.2 & 7.6 & 8.7\end{array}$

$\begin{array}{lllllllllll}150.0 & 8.4 & 8.2 & 9.9 & 8.7 & 7.0 & 7.7 & 8.4 & 8.4 & 8.8 & 9.4\end{array}$

$\begin{array}{lllllllllll}165.0 & 8.9 & 8.5 & 9.9 & 9.2 & 7.5 & 7.9 & 8.5 & 8.1 & 9.3 & 8.7\end{array}$

$\begin{array}{lllllllllll}180.0 & 9.4 & 8.6 & 9.7 & 9.1 & 7.8 & 8.2 & 8.7 & 9.0 & 9.7 & 9.1\end{array}$

$\begin{array}{lllllllllll}195.0 & 8.8 & 9.1 & 9.8 & 9.2 & 8.6 & 8.4 & 9.3 & 8.5 & 10.4 & 9.9\end{array}$

$\begin{array}{lllllllllll}210.0 & 8.8 & 8.8 & 10.6 & 9.7 & 8.4 & 9.4 & 9.7 & 9.5 & 9.9 & 9.8\end{array}$

$\begin{array}{lllllllllll}225.0 & 8.9 & 9.3 & 10.0 & 9.9 & 9.5 & 9.1 & 10.0 & 9.8 & 9.6 & 8.6\end{array}$

$\begin{array}{lllllllllll}240.0 & 9.6 & 9.9 & 10.4 & 10.4 & 9.0 & 9.1 & 9.5 & 10.0 & 10.1 & 9.1\end{array}$

$\begin{array}{lllllllllll}255.0 & 10.3 & 10.3 & 11.2 & 10.6 & 10.0 & 10.2 & 10.5 & 10.3 & 11.2 & 11.2\end{array}$ $\begin{array}{lllllllllll}270.0 & 13.1 & 12.1 & 12.8 & 14.1 & 11.6 & 11.4 & 11.6 & 12.6 & 11.5 & 12.8\end{array}$

AVG \% $\quad \begin{array}{llllllllll}7.6 & 7.7 & 8.5 & 7.9 & 7.0 & 7.3 & 7.8 & 7.6 & 8.0 & 7.9\end{array}$ $\begin{array}{lllllllllll}\text { WASTE : } & 9.0 & 8.9 & 10.0 & 9.4 & 8.2 & 8.5 & 9.2 & 9.0 & 9.7 & 9.2\end{array}$ $\begin{array}{lllllllllll}\text { STRG } \mathrm{cm} & 21.0 & 21.3 & 23.4 & 21.7 & 19.2 & 20.2 & 21.5 & 21.0 & 22.1 & 21.8\end{array}$ 
DATE: $\quad 08-07-86$

DAY: $\quad 950$

PROBE: $\quad 6031$ STANDARD COUNTS: 8621

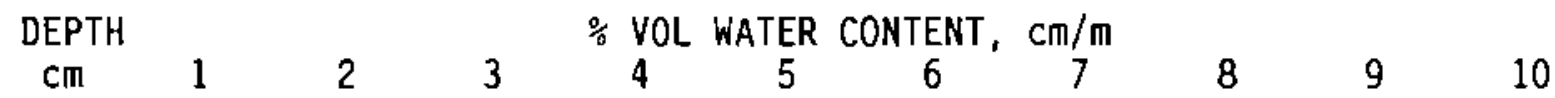

$\begin{array}{lllllllllll}30.0 & 3.3 & 4.2 & 3.6 & 3.8 & 3.2 & 4.4 & 4.2 & 3.8 & 2.4 & 3.4\end{array}$ $\begin{array}{lllllllllll}45.0 & 6.0 & 6.5 & 6.7 & 6.2 & 5.9 & 6.3 & 6.1 & 6.3 & 6.2 & 6.4\end{array}$ $\begin{array}{lllllllllll}60.0 & 7.3 & 7.7 & 7.4 & 7.4 & 6.2 & 6.6 & 7.7 & 6.7 & 7.2 & 7.6\end{array}$ $\begin{array}{lllllllllll}75.0 & 7.5 & 8.1 & 8.3 & 8.0 & 6.4 & 6.5 & 7.9 & 7.5 & 7.8 & 7.9\end{array}$ $\begin{array}{lllllllllll}90.0 & 7.8 & 8.8 & 8.5 & 8.4 & 6.6 & 7.3 & 8.2 & 7.6 & 8.2 & 8.1\end{array}$ $\begin{array}{lllllllllll}105.0 & 7.3 & 8.0 & 9.2 & 8.4 & 7.8 & 7.3 & 8.7 & 7.8 & 8.6 & 8.1\end{array}$ $\begin{array}{lllllllllll}120.0 & 7.9 & 8.6 & 9.5 & 8.5 & 7.0 & 7.0 & 8.8 & 8.3 & 8.2 & 8.1\end{array}$ $\begin{array}{lllllllllll}135.0 & 7.2 & 8.9 & 9.1 & 8.5 & 7.2 & 7.5 & 8.3 & 8.2 & 8.7 & 8.2\end{array}$ $\begin{array}{lllllllllll}150.0 & 8.0 & 9.3 & 9.4 & 9.0 & 7.4 & 8.1 & 9.3 & 8.6 & 8.8 & 9.2\end{array}$ $\begin{array}{lllllllllll}165.0 & 8.9 & 8.7 & 9.8 & 9.0 & 7.6 & 8.2 & 8.8 & 8.9 & 9.4 & 9.4\end{array}$ $\begin{array}{lllllllllll}180.0 & 9.1 & 9.6 & 9.7 & 8.9 & 7.6 & 8.4 & 8.6 & 8.7 & 9.1 & 8.4\end{array}$ $\begin{array}{lllllllllll}195.0 & 9.2 & 9.3 & 9.8 & 9.5 & 8.8 & 8.5 & 8.9 & 8.9 & 10.2 & 9.5\end{array}$ $\begin{array}{lllllllllll}210.0 & 9.3 & 9.3 & 10.3 & 9.3 & 8.7 & 9.1 & 9.6 & 9.5 & 10.3 & 9.7\end{array}$ $\begin{array}{lllllllllll}225.0 & 9.3 & 9.6 & 10.2 & 9.3 & 9.1 & 9.6 & 9.2 & 9.6 & 9.8 & 8.8\end{array}$ $\begin{array}{lllllllllll}240.0 & 9.2 & 9.0 & 10.5 & 9.6 & 9.2 & 9.5 & 8.9 & 10.3 & 10.2 & 9.5\end{array}$ $\begin{array}{lllllllllll}255.0 & 10.7 & 10.7 & 10.7 & 10.9 & 10.3 & 10.1 & 10.1 & 10.9 & 11.4 & 10.8\end{array}$ $\begin{array}{lllllllllll}270.0 & 12.8 & 12.9 & 12.7 & 13.4 & 11.7 & 12.2 & 11.8 & 12.5 & 12.0 & 13.4\end{array}$

AVG \% $\quad \begin{array}{llllllllll}7.5 & 8.0 & 8.4 & 7.9 & 7.0 & 7.3 & 7.8 & 7.8 & 8.0 & 7.8\end{array}$ $\begin{array}{lllllllllll}\text { WASTE } \% & 9.0 & 9.3 & 10.0 & 9.2 & 8.3 & 8.8 & 9.1 & 9.2 & 9.7 & 9.2\end{array}$ $\begin{array}{lllllllllll}\text { STRG cm } & 20.7 & 22.1 & 23.1 & 21.8 & 19.2 & 20.1 & 21.6 & 21.3 & 22.1 & 21.6\end{array}$ 
$\begin{array}{lcl}\text { DATE: } & 08-22-86 & \\ \text { DAY: } & 965 & \\ \text { PROBE: } & 6031 \quad \text { STANDARD COUNTS: } \quad 8622\end{array}$

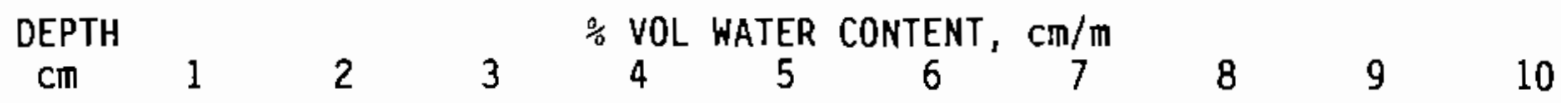

$\begin{array}{lllllllllll}30.0 & 2.4 & 2.7 & 2.3 & 2.9 & 2.3 & 3.1 & 0.0 & 2.7 & 2.3 & 2.7\end{array}$

$\begin{array}{lllllllllll}45.0 & 4.7 & 6.6 & 5.6 & 5.4 & 5.6 & 5.2 & 3.0 & 5.1 & 5.5 & 6.2\end{array}$

$\begin{array}{lllllllllll}60.0 & 5.8 & 7.5 & 5.9 & 6.8 & 6.1 & 5.7 & 5.3 & 6.2 & 7.2 & 7.1\end{array}$

$\begin{array}{lllllllllll}75.0 & 6.1 & 7.3 & 6.1 & 7.4 & 6.6 & 6.8 & 7.4 & 7.0 & 7.8 & 7.4\end{array}$

$\begin{array}{lllllllllll}90.0 & 6.0 & 8.2 & 6.5 & 8.1 & 6.8 & 6.7 & 7.8 & 6.8 & 8.3 & 7.1\end{array}$

$\begin{array}{lllllllllll}105.0 & 5.7 & 8.8 & 7.7 & 8.5 & 7.5 & 6.9 & 7.3 & 7.6 & 8.7 & 8.3\end{array}$

$\begin{array}{lllllllllll}120.0 & 6.4 & 7.9 & 7.6 & 8.6 & 6.7 & 7.0 & 8.8 & 8.1 & 8.0 & 7.3\end{array}$

$\begin{array}{lllllllllll}135.0 & 6.2 & 8.3 & 7.9 & 8.6 & 7.3 & 7.6 & 8.5 & 7.3 & 7.9 & 8.2\end{array}$

$\begin{array}{lllllllllll}150.0 & 6.3 & 9.0 & 8.1 & 9.1 & 7.3 & 8.1 & 8.1 & 7.8 & 8.7 & 8.3\end{array}$

$\begin{array}{lllllllllll}165.0 & 7.2 & 9.3 & 9.1 & 9.9 & 7.1 & 7.1 & 9.1 & 8.1 & 9.4 & 8.9\end{array}$

$\begin{array}{lllllllllll}180.0 & 7.5 & 8.4 & 8.7 & 9.3 & 7.5 & 8.2 & 9.2 & 8.2 & 9.3 & 8.7\end{array}$

$\begin{array}{lllllllllll}195.0 & 7.3 & 9.1 & 9.1 & 10.0 & 8.3 & 8.5 & 8.8 & 9.2 & 10.1 & 8.7\end{array}$

$\begin{array}{lllllllllll}210.0 & 7.9 & 9.5 & 9.2 & 9.4 & 8.7 & 8.9 & 9.0 & 9.2 & 10.2 & 8.7\end{array}$

$\begin{array}{lllllllllll}225.0 & 8.4 & 8.6 & 9.3 & 9.4 & 9.8 & 8.7 & 9.5 & 9.4 & 9.8 & 8.7\end{array}$

$\begin{array}{lllllllllll}240.0 & 8.5 & 9.8 & 9.5 & 9.9 & 10.2 & 9.3 & 9.5 & 9.3 & 9.7 & 8.8\end{array}$

$\begin{array}{lllllllllll}255.0 & 10.0 & 10.4 & 10.1 & 11.0 & 10.1 & 10.3 & 8.6 & 9.7 & 10.9 & 9.8\end{array}$

$\begin{array}{lllllllllll}270.0 & 12.0 & 12.2 & 13.7 & 14.8 & 11.8 & 12.0 & 10.0 & 12.9 & 11.6 & 11.7\end{array}$

$\begin{array}{lllllllllll}\text { AVG 은 } & 6.3 & 7.7 & 7.2 & 7.9 & 6.9 & 6.9 & 7.0 & 7.2 & 7.9 & 7.3\end{array}$

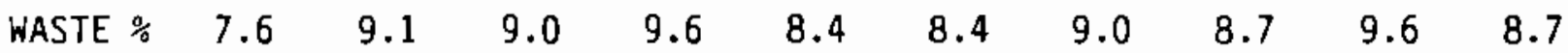
$\begin{array}{lllllllllll}\text { STRG Cm } & 17.2 & 21.2 & 19.8 & 21.7 & 19.1 & 19.1 & 19.4 & 19.7 & 21.6 & 20.2\end{array}$ 
DATE: $\quad 09-05-86$

DAY: $\quad 979$

PROBE: $\quad 6031$ STANDARD COUNTS: 8612

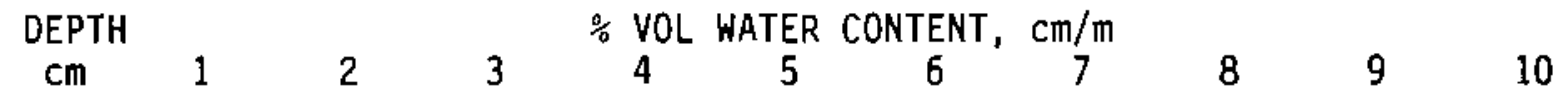

$\begin{array}{lllllllllll}30.0 & 2.2 & 3.1 & 2.5 & 2.8 & 2.8 & 3.1 & 2.3 & 3.0 & 1.9 & 2.8\end{array}$

$\begin{array}{lllllllllll}45.0 & 4.2 & 5.9 & 5.0 & 5.5 & 5.2 & 4.5 & 5.9 & 5.3 & 5.7 & 6.0\end{array}$

$\begin{array}{lllllllllll}60.0 & 6.1 & 7.1 & 5.7 & 6.6 & 6.0 & 6.0 & 6.8 & 6.7 & 7.1 & 7.1\end{array}$

$\begin{array}{lllllllllll}75.0 & 6.0 & 7.1 & 6.0 & 7.3 & 6.3 & 5.9 & 7.8 & 6.3 & 7.4 & 7.0\end{array}$

$\begin{array}{lllllllllll}90.0 & 5.3 & 7.8 & 5.8 & 7.6 & 6.3 & 6.4 & 7.8 & 6.9 & 8.0 & 7.0\end{array}$

$\begin{array}{lllllllllll}105.0 & 5.4 & 7.7 & 6.2 & 7.6 & 7.4 & 6.8 & 8.5 & 6.7 & 8.1 & 7.1\end{array}$

$\begin{array}{lllllllllll}120.0 & 5.2 & 8.1 & 6.8 & 8.3 & 6.6 & 6.3 & 8.2 & 7.5 & 7.9 & 8.0\end{array}$

$\begin{array}{lllllllllll}135.0 & 5.8 & 8.2 & 6.9 & 8.0 & 7.4 & 7.2 & 7.9 & 7.6 & 8.4 & 7.6\end{array}$

$\begin{array}{lllllllllll}150.0 & 5.5 & 8.4 & 7.6 & 8.4 & 7.0 & 7.4 & 8.5 & 7.8 & 8.8 & 8.8\end{array}$

$\begin{array}{lllllllllll}165.0 & 6.4 & 8.3 & 7.3 & 9.2 & 7.2 & 7.7 & 7.9 & 7.7 & 8.5 & 8.6\end{array}$

$\begin{array}{lllllllllll}180.0 & 6.3 & 8.1 & 7.3 & 8.6 & 7.9 & 7.6 & 8.7 & 8.0 & 8.8 & 8.0\end{array}$

$\begin{array}{lllllllllll}195.0 & 6.4 & 8.8 & 7.1 & 9.1 & 7.9 & 7.4 & 9.1 & 8.8 & 9.1 & 8.6\end{array}$

$\begin{array}{lllllllllll}210.0 & 6.8 & 10.0 & 7.7 & 9.1 & 9.1 & 9.1 & 9.0 & 9.6 & 9.9 & 8.3\end{array}$

$\begin{array}{lllllllllll}225.0 & 7.4 & 9.4 & 7.6 & 9.0 & 8.6 & 8.2 & 9.1 & 9.9 & 10.0 & 8.6\end{array}$

$\begin{array}{lllllllllll}240.0 & 7.5 & 9.5 & 7.7 & 9.2 & 8.7 & 9.5 & 9.0 & 9.9 & 9.7 & 9.2\end{array}$

$\begin{array}{lllllllllll}255.0 & 9.2 & 10.5 & 9.3 & 10.2 & 9.9 & 9.8 & 10.0 & 9.9 & 10.5 & 10.4\end{array}$

$\begin{array}{lllllllllll}270.0 & 12.0 & 13.2 & 11.9 & 13.3 & 11.7 & 12.3 & 11.6 & 12.7 & 11.9 & 12.2\end{array}$

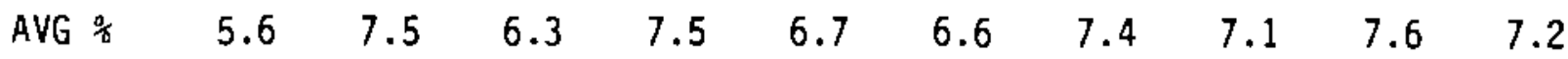

$\begin{array}{lllllllllll}\text { WASTE \% } & 6.6 & 8.9 & 7.5 & 8.9 & 8.1 & 8.1 & 8.8 & 8.8 & 9.3 & 8.6\end{array}$

$\begin{array}{lllllllllll}\text { STRG } \mathrm{cm} & 15.5 & 20.7 & 17.2 & 20.5 & 18.5 & 18.3 & 20.5 & 19.6 & 21.0 & 19.9\end{array}$ 


\begin{tabular}{|c|c|c|c|c|c|c|c|c|c|c|}
\hline $\begin{array}{l}\text { DATE: } \\
\text { DAY: } \\
\text { PROBE: }\end{array}$ & $\begin{array}{r}09-1 \\
99 \\
60\end{array}$ & & STANDARD & COUNTS & & 8284 & & & & \\
\hline $\begin{array}{l}\text { DEPTH } \\
\text { cm }\end{array}$ & 1 & 2 & 3 & $\begin{array}{l}\text { VOL WA } \\
4\end{array}$ & $\begin{array}{l}\text { ATER } \\
5\end{array}$ & $\begin{array}{c}\text { CONTENT, } \\
6\end{array}$ & $\mathrm{~cm} / \mathrm{m}$ & 8 & 9 & 10 \\
\hline 30.0 & 3.5 & 4.7 & 3.0 & 5.0 & 4.1 & 4.6 & 4.6 & 4.3 & 4.2 & 4.5 \\
\hline 45.0 & 5.1 & 6.8 & 5.4 & 6.5 & 6.1 & 6.0 & 6.2 & 5.9 & 6.3 & 6.7 \\
\hline 60.0 & 6.4 & 7.8 & 6.2 & 6.8 & 6.2 & 6.9 & 6.8 & 6.9 & 7.1 & 7.3 \\
\hline 75.0 & 6.1 & 7.9 & 6.1 & 7.8 & 6.6 & 7.2 & 7.2 & 7.2 & 8.0 & 7.7 \\
\hline 90.0 & 6.2 & 8.0 & 6.6 & 8.3 & 7.4 & 6.9 & 7.7 & 7.2 & 8.2 & 8.1 \\
\hline 105.0 & 5.7 & 8.8 & 6.9 & 9.2 & 7.2 & 7.0 & 8.8 & 8.2 & 8.4 & 8.0 \\
\hline 120.0 & 5.8 & 8.5 & 7.6 & 8.7 & 7.6 & 7.5 & 9.4 & 8.1 & 8.8 & 8.2 \\
\hline 135.0 & 5.7 & 9.1 & 7.4 & 8.5 & 7.4 & 8.4 & 8.7 & 7.9 & 8.7 & 8.9 \\
\hline 150.0 & 6.5 & 9.2 & 7.7 & 8.8 & 7.4 & 8.8 & 8.8 & 8.3 & 9.3 & 9.3 \\
\hline 165.0 & 7.3 & 9.7 & 8.0 & 9.9 & 8.3 & 8.7 & 9.1 & 8.2 & 10.3 & 9.6 \\
\hline 180.0 & 7.2 & 9.2 & 8.3 & 9.5 & 7.9 & 8.5 & 8.9 & 9.0 & 9.7 & 8.8 \\
\hline 195.0 & 7.4 & 10.1 & 8.5 & 9.8 & 8.6 & 8.8 & 9.0 & 9.6 & 9.6 & 9.9 \\
\hline 210.0 & 8.2 & 10.0 & 8.8 & 10.0 & 9.6 & 10.1 & 10.1 & 9.8 & 10.6 & 9.3 \\
\hline 225.0 & 7.6 & 9.6 & 8.6 & 10.1 & 10.0 & 10.0 & 9.2 & 9.8 & 10.2 & 9.1 \\
\hline 240.0 & 8.3 & 10.7 & 8.4 & 10.0 & 9.7 & 10.3 & 10.2 & 14.5 & 10.8 & 9.5 \\
\hline 255.0 & 9.3 & 11.4 & 9.4 & 11.0 & 10.9 & 11.7 & 10.0 & 11.0 & 11.9 & 11.3 \\
\hline 270.0 & 13.1 & 13.1 & 13.4 & 14.7 & 12.5 & 13.0 & 12.5 & 13.1 & 12.3 & 22.3 \\
\hline AVG $\%$ & 6.2 & 8.3 & 6.9 & 8.2 & 7.4 & 7.7 & 7.9 & 8.0 & 8.4 & 8.0 \\
\hline WASTE \% & 7.5 & 9.8 & 8.3 & 9.7 & 8.8 & 9.3 & 9.3 & 9.9 & 10.1 & 9.4 \\
\hline STRG $\mathrm{cm}$ & 17.2 & 22.9 & 18.9 & 22.7 & 20.2 & 21.3 & 21.8 & 22.0 & 23.0 & 22.0 \\
\hline
\end{tabular}


$\begin{array}{ll}\text { DATE: } & 10-03-86 \\ \text { DAY: } & 1007\end{array}$

PROBE: $\quad 6031$ STANDARD COUNTS: 8655

\begin{tabular}{|c|c|c|c|c|c|c|c|c|c|c|}
\hline $\begin{array}{l}\text { DEPTH } \\
\mathrm{cm}\end{array}$ & 1 & 2 & 3 & $\begin{array}{l}\text { VOL W } \\
4\end{array}$ & $\begin{array}{l}\text { TER CO } \\
5\end{array}$ & $\begin{array}{l}\text { ENT, } \\
6\end{array}$ & $\frac{m / m}{7}$ & 8 & 9 & 10 \\
\hline 30.0 & 4.5 & 5.4 & 3.7 & 5.3 & 4.9 & 5.4 & 5.4 & 4.7 & 4.7 & 4.3 \\
\hline 45.0 & 5.6 & 6.1 & 5.4 & 5.5 & 6.2 & 5.6 & 6.0 & 5.3 & 6.2 & 6.6 \\
\hline 60.0 & 5.9 & 7.1 & 5.7 & 6.4 & 6.1 & 5.6 & 6.5 & 5.7 & 7.1 & 6.5 \\
\hline 75.0 & 6.0 & 7.2 & 6.4 & 6.8 & 6.7 & 6.4 & 6.9 & 6.7 & 7.7 & 6.9 \\
\hline 90.0 & 5.0 & 6.8 & 6.1 & 7.4 & 6.6 & 6.4 & 7.6 & 6.8 & 8.1 & 7.3 \\
\hline 105.0 & 5.3 & 7.8 & 6.8 & 7.2 & 6.5 & 6.4 & 8.5 & 6.8 & 8.0 & 7.9 \\
\hline 120.0 & 5.4 & 7.4 & 7.0 & 7.9 & 6.8 & 6.3 & 8.5 & 7.4 & 8.2 & 7.1 \\
\hline 135.0 & 5.9 & 7.9 & 6.6 & 7.8 & 6.5 & 7.2 & 8.5 & 7.3 & 7.2 & 8.2 \\
\hline 150.0 & 5.7 & 8.1 & 7.2 & 8.3 & 7.0 & 7.7 & 8.7 & 7.9 & 8.4 & 8.3 \\
\hline 165.0 & 6.0 & 8.7 & 7.5 & 8.7 & 6.3 & 7.3 & 8.9 & 7.4 & 8.9 & 9.0 \\
\hline 180.0 & 6.3 & 8.2 & 7.3 & 8.7 & 7.3 & 7.4 & 9.2 & 7.3 & 9.0 & 8.1 \\
\hline 195.0 & 6.4 & 8.8 & 7.9 & 8.5 & 7.7 & 7.6 & 9.4 & 8.6 & 9.2 & 8.6 \\
\hline 210.0 & 6.5 & 9.0 & 7.4 & 8.8 & 8.4 & 8.6 & 9.6 & 9.6 & 9.5 & 9.1 \\
\hline 225.0 & 6.8 & 9.4 & 8.0 & 8.9 & 8.4 & 8.3 & 9.2 & 9.0 & 9.5 & 8.4 \\
\hline 240.0 & 7.0 & 9.3 & 7.7 & 8.9 & 8.8 & 9.4 & 9.1 & 9.3 & 9.5 & 8.8 \\
\hline 255.0 & 9.0 & 10.5 & 8.8 & 10.4 & 9.7 & 9.4 & 10.1 & 9.9 & 11.0 & 10.6 \\
\hline 270.0 & 10.9 & 12.4 & 11.9 & 13.5 & 10.7 & 12.6 & 11.3 & 12.0 & 11.7 & 12.5 \\
\hline
\end{tabular}

$\begin{array}{lllllllllll}\text { AVG } \% & 5.7 & 7.5 & 6.4 & 7.4 & 6.7 & 6.8 & 7.8 & 7.0 & 7.8 & 7.4\end{array}$

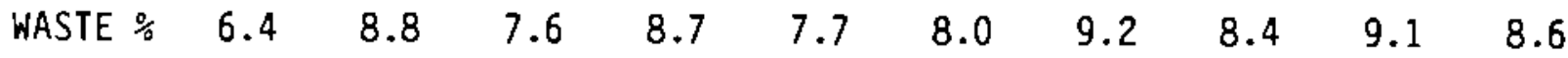
$\begin{array}{lllllllllll}\text { STRG Cm } & 15.7 & 20.7 & 17.7 & 20.3 & 18.4 & 18.6 & 21.4 & 19.4 & 21.4 & 20.3\end{array}$ 


\begin{tabular}{|c|c|c|c|c|c|c|c|c|c|c|}
\hline $\begin{array}{l}\text { DATE: } \\
\text { DAY: } \\
\text { PROBE: }\end{array}$ & $\begin{array}{r}10-2 \\
102 \\
60\end{array}$ & & STANDARD & D COUNTS & & 3811 & & & & \\
\hline $\begin{array}{l}\text { DEPTH } \\
\text { cm }\end{array}$ & 1 & 2 & 3 & $\begin{array}{l}\text { VOL WA } \\
4\end{array}$ & $\underset{5}{\text { ATER }}$ & $\begin{array}{l}\text { ONTENT } \\
6\end{array}$ & $\begin{array}{c}\mathrm{cm} / \mathrm{m} \\
7\end{array}$ & 8 & 9 & 10 \\
\hline 30.0 & 2.9 & 4.0 & 3.6 & 3.7 & 3.4 & 3.8 & 3.3 & 4.0 & 2.7 & 3.3 \\
\hline 45.0 & 4.7 & 6.3 & 5.0 & 5.7 & 4.9 & 5.8 & 4.5 & 5.8 & 5.4 & 5.4 \\
\hline 60.0 & 5.4 & 7.0 & 5.8 & 5.8 & 5.9 & 6.1 & 6.1 & 6.2 & 6.3 & 6.4 \\
\hline 75.0 & 6.2 & 6.1 & 6.4 & 6.7 & 5.5 & 6.0 & 6.2 & 5.9 & 6.3 & 5.9 \\
\hline 90.0 & 5.2 & 6.8 & 5.6 & 6.9 & 5.9 & 6.6 & 6.4 & 6.1 & 6.8 & 6.6 \\
\hline 105.0 & 4.8 & 7.0 & 6.0 & 7.1 & 6.0 & 5.6 & 7.1 & 6.5 & 7.2 & 6.7 \\
\hline 120.0 & 5.1 & 7.9 & 6.9 & 7.4 & 5.8 & 5.8 & 7.4 & 6.9 & 7.1 & 6.5 \\
\hline 135.0 & 5.6 & 7.4 & 7.2 & 7.6 & 5.8 & 7.0 & 7.3 & 7.4 & 6.6 & 7.0 \\
\hline 150.0 & 5.6 & 7.7 & 7.5 & 7.5 & 6.4 & 7.1 & 7.8 & 7.4 & 7.8 & 7.6 \\
\hline 165.0 & 6.4 & 7.9 & 7.9 & 8.3 & 6.6 & 7.2 & 8.2 & 7.4 & 8.6 & 8.0 \\
\hline 180.0 & 6.5 & 7.9 & 7.6 & 8.2 & 6.4 & 6.7 & 7.9 & 7.1 & 8.3 & 7.6 \\
\hline 195.0 & 6.4 & 8.2 & 7.7 & 8.6 & 7.5 & 8.1 & 8.1 & 8.3 & 9.0 & 7.7 \\
\hline 210.0 & 6.4 & 9.0 & 8.3 & 9.2 & 7.5 & 7.9 & 8.2 & 8.2 & 9.2 & 7.9 \\
\hline 225.0 & 6.5 & 8.1 & 8.2 & 8.6 & 8.0 & 7.8 & 8.1 & 8.1 & 9.2 & 8.0 \\
\hline 240.0 & 6.4 & 8.2 & 8.0 & 8.6 & 7.9 & 8.8 & 8.1 & 8.5 & 9.3 & 7.7 \\
\hline 255.0 & 8.7 & 9.7 & 8.7 & 9.6 & 8.8 & 9.1 & 9.1 & 9.4 & 9.9 & 9.9 \\
\hline 270.0 & 11.0 & 11.5 & 12.1 & 14.2 & 11.1 & 10.6 & 10.8 & 11.6 & 11.6 & 11.7 \\
\hline AVG $\%$ & 5.5 & 7.0 & 6.5 & 7.0 & 6.0 & 6.4 & 6.7 & 6.7 & 7.0 & 6.6 \\
\hline WASTE $\%$ & 6.3 & 8.1 & 7.9 & 8.4 & 7.2 & 7.7 & 8.0 & 7.9 & 8.8 & 7.8 \\
\hline STRG cm & 15.0 & 19.2 & 17.8 & 19.3 & 16.5 & 17.7 & 18.4 & 18.3 & 19.4 & 18.1 \\
\hline
\end{tabular}


$\begin{array}{lcl}\text { DATE : } & 10-31-86 & \\ \text { DAY: } & 1035 & \\ \text { PROBE: } & 6031 \quad \text { STANDARD COUNTS: } \quad 8700\end{array}$

\begin{tabular}{|c|c|c|c|c|c|c|c|c|c|c|}
\hline $\begin{array}{c}\text { DEPTH } \\
\mathrm{cm}\end{array}$ & 1 & 2 & 3 & $\begin{array}{l}\text { VOL } \\
4\end{array}$ & $\begin{array}{c}\text { ATER CO } \\
5\end{array}$ & $\underset{6}{\text { TENT, }}$ & $\begin{array}{c}\mathrm{cm} / \mathrm{m} \\
7\end{array}$ & 8 & 9 & 10 \\
\hline 30.0 & 5.5 & 6.8 & 5.9 & 5.2 & 5.1 & 5.2 & 5.3 & 5.8 & 5.2 & \\
\hline 45.0 & 5.4 & 6.6 & 6.0 & 6.1 & 5.9 & 5.6 & 6.3 & 6.6 & 6.0 & 6. \\
\hline 60.0 & 5.8 & 7.1 & 6.0 & 6.7 & 5.7 & 5.7 & 6.8 & 6.4 & 5.9 & 6. \\
\hline 75.0 & 5.9 & 7.6 & 5.8 & 6.7 & 5.6 & 6.0 & 6.7 & 6.2 & 6.9 & 6. \\
\hline 90.0 & 5.3 & 6.6 & 5.9 & 7.3 & 5.4 & 6.6 & 7.1 & 6.9 & 6.8 & 6. \\
\hline 105.0 & 5.1 & 7.3 & 6.4 & 7.6 & 6.2 & 5.8 & 7.9 & 6.8 & 7.4 & 7. \\
\hline 120.0 & 5.1 & 7.7 & 7.0 & 8.4 & 5.9 & 5.7 & 7.6 & 7.5 & 7.4 & \\
\hline 135.0 & 5.1 & 7.4 & 6.6 & 7.7 & 6.0 & 6.9 & 7.9 & 7.2 & 6.9 & 7. \\
\hline 150.0 & 6.0 & 7.7 & 6.6 & 8.3 & 6.4 & 6.9 & 8.6 & 7.0 & 8.1 & 8. \\
\hline 165.0 & 6.7 & 8.4 & 7.1 & 9.1 & 6.0 & 6.6 & 8.6 & 7.5 & 8.6 & 7 \\
\hline 180.0 & 6.7 & 7.8 & 7.3 & 9.5 & 6.9 & 6.8 & 8.2 & 7.4 & 8.9 & 8.1 \\
\hline 195.0 & 7.0 & 8.4 & 7.2 & 8.6 & 7.8 & 7.3 & 8.0 & 8.0 & 8.8 & 8. \\
\hline 210.0 & 6.4 & 9.1 & 7.7 & 9.7 & 8.4 & 8.2 & 8.1 & 8.6 & 9.2 & 8.1 \\
\hline 225.0 & 7.0 & 8.4 & 7.8 & 9.1 & 8.4 & 8.1 & 8.5 & 8.4 & 8.7 & 8. \\
\hline 240.0 & 6.7 & 9.2 & 7.6 & 9.7 & 9.1 & 8.4 & 9.1 & 9.4 & 9.5 & 8.2 \\
\hline 255.0 & 9.0 & 10.1 & 8.8 & 10.4 & 9.8 & 9.2 & 9.0 & 9.0 & 9.9 & 10.3 \\
\hline 270.0 & 11.5 & 12.7 & 10.8 & 13.9 & 11.4 & 11.1 & 11.3 & 11.6 & 11.1 & 11.5 \\
\hline
\end{tabular}

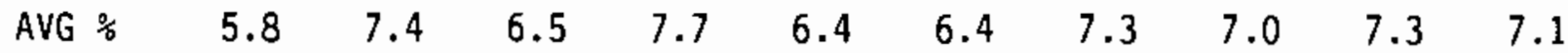

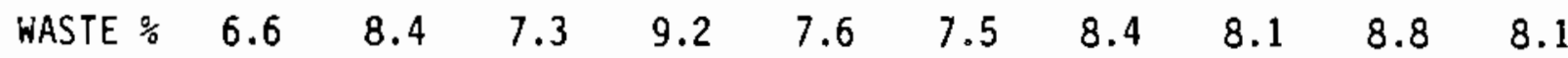

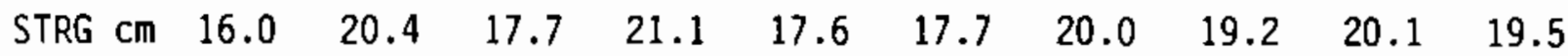


DATE: $\quad 11-17-86$

DAY: $\quad 1052$

PROBE: $\quad 6031$ STANDARD COUNTS: 8831

\begin{tabular}{|c|c|c|c|c|c|c|c|c|c|c|}
\hline $\begin{array}{l}\text { DEPTH } \\
\mathrm{cm}\end{array}$ & 1 & 2 & 3 & $\frac{1}{4}$ VOL W & $\begin{array}{l}\text { TER CC } \\
5\end{array}$ & $\begin{array}{l}\text { TENT, } \\
6\end{array}$ & $\mathrm{~cm} / \mathrm{m}$ & 8 & 9 & 10 \\
\hline 30.0 & 4.2 & 5.2 & 4.4 & 4.6 & 4.5 & 4.9 & 4.9 & 1.0 & 4.2 & 3.5 \\
\hline 45.0 & 5.5 & 6.4 & 5.5 & 5.7 & 5.5 & 5.6 & 5.5 & 4.4 & 5.8 & 5.9 \\
\hline 60.0 & 5.9 & 6.5 & 6.0 & 5.8 & 2.6 & 6.2 & 6.4 & 5.8 & 6.6 & 5.8 \\
\hline 75.0 & 5.4 & 6.4 & 5.6 & 6.4 & 5.6 & 5.4 & 5.6 & 5.8 & 6.8 & 5.9 \\
\hline 90.0 & 5.2 & 6.5 & 5.4 & 6.4 & 5.6 & 5.5 & 6.4 & 6.4 & 6.8 & 5.8 \\
\hline 105.0 & 5.3 & 6.9 & 5.6 & 6.8 & 5.8 & 5.2 & 7.2 & 5.6 & 7.1 & 6.6 \\
\hline 120.0 & 4.9 & 7.2 & 6.4 & 7.3 & 6.3 & 6.1 & 7.1 & 5.8 & 6.9 & 6.5 \\
\hline 135.0 & 4.8 & 7.8 & 6.8 & 7.0 & 6.3 & 7.0 & 7.2 & 7.1 & 7.1 & 6.9 \\
\hline 150.0 & 5.5 & 8.2 & 7.0 & 7.1 & 6.4 & 6.9 & 7.8 & 6.5 & 7.9 & 7.6 \\
\hline 165.0 & 6.6 & 7.9 & 7.4 & 7.8 & 6.3 & 6.6 & 7.5 & 7.2 & 8.4 & 7.6 \\
\hline 180.0 & 6.4 & 7.7 & 7.2 & 7.9 & 6.5 & 7.0 & 7.9 & 6.9 & 8.6 & 7.8 \\
\hline 195.0 & 6.5 & 7.6 & 8.1 & 8.4 & 7.5 & 7.4 & 7.3 & 7.4 & 8.8 & 7.4 \\
\hline 210.0 & 6.4 & 8.1 & 8.3 & 8.1 & 7.6 & 7.5 & 7.8 & 7.7 & 9.1 & 7.2 \\
\hline 225.0 & 6.6 & 7.8 & 8.2 & 8.4 & 8.0 & 8.0 & 8.0 & 8.0 & 8.4 & 7.3 \\
\hline 240.0 & 7.1 & 8.3 & 8.1 & 8.4 & 7.4 & 8.0 & 7.8 & 8.8 & 9.1 & 8.0 \\
\hline 255.0 & 8.1 & 9.7 & 9.0 & 10.1 & 8.6 & 9.8 & 8.7 & 9.1 & 10.2 & 9.4 \\
\hline 270.0 & 13.9 & 11.3 & 11.2 & 13.7 & 10.7 & 11.5 & 10.3 & 8.9 & 11.5 & 10.6 \\
\hline AVG $\%$ & 5.5 & 6.9 & 6.4 & 6.8 & 5.9 & 6.3 & 6.7 & 6.1 & 7.2 & 6.4 \\
\hline WASTE $\%$ & 6.4 & 7.9 & 7.8 & 8.0 & 7.1 & 7.3 & 7.7 & $7.5^{\circ}$ & 8.6 & 7.6 \\
\hline STRG $\mathrm{cm}$ & 15.3 & 19.1 & 17.6 & 18.8 & 16.3 & 17.3 & 18.3 & 16.8 & 19.7 & 17.7 \\
\hline
\end{tabular}


DATE: $\quad 12-01-86$

DAY: $\quad 1066$

PROBE: $\quad 6031$ STANDARD COUNTS: 8646

\begin{tabular}{|c|c|c|c|c|c|c|c|c|c|c|}
\hline $\begin{array}{l}\text { DEPTH } \\
\mathrm{cm}\end{array}$ & 1 & 2 & 3 & $\begin{array}{l}\text { VOL W/ } \\
4\end{array}$ & $\begin{array}{l}\text { TER CO } \\
5\end{array}$ & $\begin{array}{l}\text { TENT, } \\
6\end{array}$ & $\begin{array}{c}\mathrm{cm} / \mathrm{m} \\
7\end{array}$ & 8 & 9 & 10 \\
\hline 30.0 & 7.1 & 7.8 & 7.2 & 7.1 & 7.0 & 6.5 & 7.0 & 7.7 & 7.7 & 6.7 \\
\hline 45.0 & 6.5 & 7.8 & 6.7 & 6.7 & 7.1 & 6.8 & 7.2 & 7.3 & 7.8 & 7.2 \\
\hline 60.0 & 6.4 & 7.2 & 6.2 & 6.3 & 6.5 & 6.0 & 7.1 & 6.7 & 7.2 & 6.7 \\
\hline 75.0 & 7.0 & 6.9 & 6.0 & 6.4 & 6.2 & 6.5 & 6.5 & 6.8 & 6.8 & 6.4 \\
\hline 90.0 & 5.5 & 6.4 & 6.5 & 7.0 & 6.3 & 6.7 & 7.1 & 6.7 & 7.3 & 6.9 \\
\hline 105.0 & 4.8 & 7.3 & 6.8 & 6.6 & 6.9 & 5.9 & 7.0 & 7.0 & 7.2 & 6.9 \\
\hline 120.0 & 5.5 & 7.1 & 7.0 & 7.4 & 6.2 & 6.0 & 7.3 & 7.1 & 7.4 & 7.3 \\
\hline 135.0 & 5.1 & 7.8 & 6.8 & 7.2 & 6.0 & 6.6 & 7.2 & 7.5 & 7.6 & 7.4 \\
\hline 150.0 & 5.4 & 7.5 & 6.8 & 7.7 & 6.5 & 7.1 & 7.7 & 6.7 & 8.6 & 7.9 \\
\hline 165.0 & 6.1 & 8.1 & 7.7 & 8.5 & 6.2 & 6.7 & 8.2 & 7.4 & 8.6 & 7.7 \\
\hline 180.0 & 5.7 & 8.0 & 7.9 & 8.1 & 6.7 & 6.9 & 7.7 & 7.9 & 9.3 & 8.5 \\
\hline 195.0 & 5.7 & 7.8 & 7.8 & 8.1 & 6.8 & 7.5 & 7.8 & 8.7 & 9.1 & 8.8 \\
\hline 210.0 & 6.7 & 8.7 & 7.9 & 8.0 & 7.8 & 8.0 & 8.4 & 8.5 & 9.5 & 8.2 \\
\hline 225.0 & 7.1 & 7.7 & 8.0 & 8.2 & 7.9 & 8.3 & 8.1 & 8.9 & 9.5 & 8.1 \\
\hline 240.0 & 6.9 & 8.7 & 7.8 & 8.7 & 7.9 & 8.9 & 8.1 & 9.3 & 9.1 & 8.1 \\
\hline 255.0 & 8.8 & 10.0 & 8.3 & 10.0 & 9.2 & 9.9 & 8.5 & 9.2 & 10.4 & 10.1 \\
\hline 270.0 & 11.5 & 12.5 & 11.3 & 12.7 & 10.7 & 11.3 & 11.2 & 11.4 & 11.2 & 12.1 \\
\hline
\end{tabular}

$\begin{array}{lllllllllll}\text { AVG } \% & 5.9 & 7.3 & 6.8 & 7.2 & 6.5 & 6.7 & 7.1 & 7.3 & 7.8 & 7.2\end{array}$ $\begin{array}{lllllllllll}\text { WASTE } \% & 6.2 & 8.1 & 7.7 & 8.2 & 7.1 & 7.6 & 8.0 & 8.2 & 9.1 & 8.2\end{array}$ $\begin{array}{lllllllllll}\text { STRG } \mathrm{cm} & 16.2 & 20.2 & 18.7 & 19.7 & 17.9 & 18.4 & 19.6 & 20.0 & 21.5 & 19.9\end{array}$ 
DATE: $\quad 12-29-86$

DAY: $\quad 1094$

PROBE: $\quad 6031$ STANDARD COUNTS: 8641

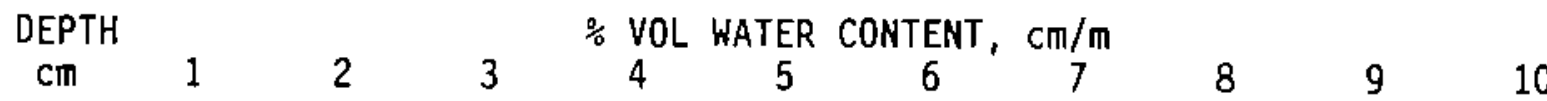

$\begin{array}{lllllllllll}30.0 & 8.5 & 9.1 & 8.7 & 9.9 & 9.1 & 8.9 & 9.0 & 9.6 & 8.4 & 9.0\end{array}$ $\begin{array}{lllllllllll}45.0 & 10.5 & 10.6 & 9.8 & 10.0 & 11.1 & 9.8 & 10.2 & 10.7 & 10.3 & 10.6\end{array}$ $\begin{array}{lllllllllll}60.0 & 9.7 & 9.4 & 8.4 & 8.5 & 11.0 & 9.0 & 10.2 & 10.0 & 10.6 & 9.0\end{array}$ $\begin{array}{lllllllllll}75.0 & 7.6 & 8.1 & 7.0 & 7.3 & 8.2 & 7.8 & 7.5 & 7.9 & 8.8 & 8.1\end{array}$ $\begin{array}{lllllllllll}90.0 & 6.5 & 7.2 & 5.8 & 6.7 & 7.4 & 7.3 & 7.3 & 7.3 & 7.6 & 6.5\end{array}$ $\begin{array}{lllllllllll}105.0 & 5.8 & 7.6 & 6.6 & 7.0 & 6.8 & 5.9 & 6.9 & 7.3 & 7.5 & 6.9\end{array}$ $\begin{array}{lllllllllll}120.0 & 5.5 & 7.4 & 7.0 & 7.1 & 6.2 & 6.1 & 7.1 & 7.0 & 6.8 & 7.1\end{array}$ $\begin{array}{lllllllllll}135.0 & 5.4 & 7.8 & 7.1 & 7.2 & 6.5 & 6.4 & 7.5 & 6.4 & 7.3 & 7.0\end{array}$ $\begin{array}{lllllllllll}150.0 & 5.8 & 8.0 & 6.6 & 7.5 & 6.1 & 6.8 & 7.9 & 6.7 & 7.8 & 8.3\end{array}$ $\begin{array}{lllllllllll}165.0 & 6.4 & 7.8 & 8.2 & 7.8 & 6.7 & 6.6 & 8.1 & 7.4 & 8.7 & 8.1\end{array}$ $\begin{array}{lllllllllll}180.0 & 6.4 & 8.0 & 8.5 & 8.3 & 6.5 & 6.4 & 8.2 & 7.7 & 8.2 & 8.0\end{array}$ $\begin{array}{lllllllllll}195.0 & 6.5 & 8.6 & 7.8 & 7.3 & 6.9 & 6.9 & 7.8 & 8.1 & 8.9 & 7.9\end{array}$ $\begin{array}{lllllllllll}210.0 & 6.1 & 8.4 & 8.3 & 8.4 & 7.5 & 8.2 & 8.0 & 8.2 & 8.9 & 8.2\end{array}$ $\begin{array}{lllllllllll}225.0 & 6.7 & 8.5 & 7.4 & 8.4 & 7.3 & 8.1 & 8.0 & 7.8 & 8.7 & 8.3\end{array}$ $\begin{array}{lllllllllll}240.0 & 6.8 & 8.8 & 7.9 & 8.5 & 7.8 & 8.6 & 7.1 & 8.4 & 9.1 & 8.1\end{array}$ $\begin{array}{lllllllllll}255.0 & 8.7 & 9.6 & 8.6 & 10.4 & 8.5 & 9.6 & 8.3 & 9.6 & 10.4 & 10.3\end{array}$ $\begin{array}{lllllllllll}270.0 & 11.7 & 12.4 & 12.1 & 12.4 & 10.6 & 11.5 & 10.8 & 11.5 & 11.2 & 12.0\end{array}$

AVG \% $\quad \begin{array}{llllllllll}6.6 & 7.9 & 7.3 & 7.7 & 7.3 & 7.2 & 7.6 & 7.7 & 8.1 & 7.7\end{array}$ $\begin{array}{lllllllllll}\text { WASTE } \% & 6.4 & 8.3 & 7.8 & 8.0 & 7.0 & 7.4 & 7.9 & 7.8 & 8.6 & 8.1\end{array}$ $\begin{array}{lllllllllll}\text { STRG Cm } & 18.2 & 21.8 & 20.0 & 21.1 & 20.0 & 19.8 & 20.9 & 21.1 & 22.3 & 21.3\end{array}$ 
DATE: $\quad 01-12-87$

DAY: $\quad 1108$

PROBE: $\quad 6031$ STANDARD COUNTS: 8867

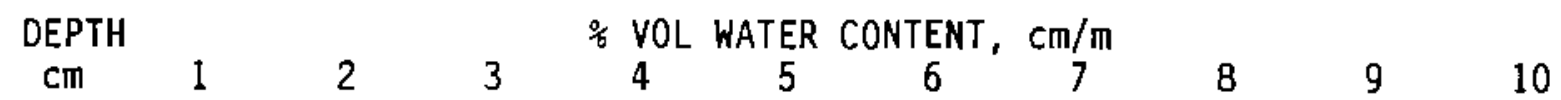

$\begin{array}{lllllllllll}30.0 & 6.4 & 7.6 & 7.7 & 7.3 & 6.6 & 7.4 & 7.4 & 8.1 & 7.2 & 6.9\end{array}$ $\begin{array}{lllllllllll}45.0 & 9.1 & 9.7 & 10.0 & 9.8 & 9.0 & 9.7 & 8.6 & 9.3 & 9.7 & 9.9\end{array}$ $\begin{array}{lllllllllll}60.0 & 10.2 & 9.8 & 11.1 & 9.9 & 10.5 & 9.8 & 9.5 & 10.3 & 10.1 & 10.1\end{array}$ $\begin{array}{lllllllllll}75.0 & 9.9 & 9.6 & 10.1 & 9.4 & 11.0 & 9.9 & 9.4 & 9.9 & 10.5 & 9.6\end{array}$ $\begin{array}{lllllllllll}90.0 & 8.3 & 8.6 & 8.2 & 8.0 & 10.8 & 10.3 & 8.7 & 8.5 & 9.2 & 9.0\end{array}$ $\begin{array}{lllllllllll}105.0 & 6.4 & 7.6 & 6.9 & 7.2 & 10.0 & 8.0 & 7.8 & 8.1 & 9.0 & 8.1\end{array}$ $\begin{array}{lllllllllll}120.0 & 6.3 & 7.0 & 7.3 & 7.0 & 7.4 & 7.1 & 7.6 & 7.2 & 7.7 & 6.8\end{array}$ $\begin{array}{lllllllllll}135.0 & 6.0 & 7.4 & 6.7 & 6.7 & 6.2 & 6.9 & 6.9 & 7.4 & 8.1 & 6.8\end{array}$ $\begin{array}{lllllllllll}150.0 & 5.9 & 6.8 & 7.2 & 7.4 & 5.4 & 6.5 & 7.5 & 6.9 & 7.9 & 7.4\end{array}$ $\begin{array}{lllllllllll}165.0 & 6.8 & 6.8 & 7.6 & 7.9 & 5.7 & 6.5 & 7.6 & 7.2 & 8.5 & 7.5\end{array}$ $\begin{array}{lllllllllll}180.0 & 6.4 & 7.0 & 7.2 & 8.0 & 5.7 & 6.2 & 7.4 & 6.4 & 8.4 & 7.6\end{array}$ $\begin{array}{lllllllllll}195.0 & 6.6 & 7.6 & 7.5 & 7.6 & 6.5 & 6.6 & 7.2 & 7.6 & 8.4 & 7.8\end{array}$ $\begin{array}{lllllllllll}210.0 & 6.5 & 7.2 & 7.8 & 8.0 & 6.9 & 7.3 & 8.0 & 7.8 & 8.8 & 7.3\end{array}$ $\begin{array}{lllllllllll}225.0 & 6.3 & 7.7 & 7.5 & 8.6 & 7.4 & 7.8 & 7.6 & 8.3 & 8.4 & 7.0\end{array}$ $\begin{array}{lllllllllll}240.0 & 7.2 & 8.3 & 8.0 & 8.3 & 7.6 & 8.2 & 7.1 & 8.2 & 8.5 & 8.2\end{array}$ $\begin{array}{lllllllllll}255.0 & 9.2 & 9.3 & 8.8 & 9.6 & 7.9 & 8.7 & 8.3 & 8.7 & 9.8 & 9.3\end{array}$ $\begin{array}{lllllllllll}270.0 & 11.8 & 10.3 & 10.5 & 14.1 & 9.5 & 10.8 & 10.3 & 11.1 & 11.4 & 11.2\end{array}$ $\begin{array}{lllllllllll}\text { AVG } \frac{\circ}{6} & 6.9 & 7.5 & 7.6 & 7.7 & 7.3 & 7.5 & 7.4 & 7.6 & 8.2 & 7.6\end{array}$ $\begin{array}{lllllllllll}\text { WASTE \% } & 6.5 & 7.3 & 7.5 & 8.0 & 6.5 & 7.0 & 7.5 & 7.5 & 8.4 & 7.5\end{array}$ $\begin{array}{lllllllllll}\text { STRG } \mathrm{cm} & 19.0 & 20.7 & 21.0 & 21.1 & 20.2 & 20.5 & 20.5 & 21.0 & 22.6 & 20.9\end{array}$ 
APPENDIX C

FIELD RADIOCHEMISTRY DATA 


\section{APPENDIX C}

\section{FIELD RADIOCHEMISTRY DATA}

The data shown in this appendix are concentrations and cumulative amounts of radionuclides measured in lysimeter leachates. Tritium is the only radionuclide found in the leachates of lysimeters 1 and 7 . Cobalt-60 is the only radionuclide found in the leachates of lysimeters $2,8,3,9,4$, and 10 . No measurable radionuclides have been found in the leachates of lysimeters 5 and 6. The column marked DAY is the number of days since January 1, 1984, and is used to facilitate plotting the data. The date and amount of drainage water extracted from the lysimeters is also shown in the listing. When a sample of drainage water was not analyzed for radionuclides, the sample was assigned the mean concentration of the closest sample that was counted before and after the uncounted sample. Cumulative amounts were calculated using this interpolation scheme. 


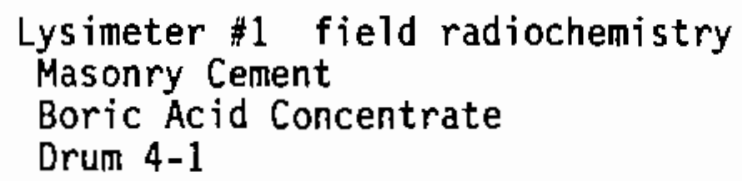

\begin{tabular}{|c|c|c|c|c|c|c|}
\hline DATE & DAY & $\begin{array}{c}\text { DRAIN } \\
\mathrm{L}\end{array}$ & $\begin{array}{l}\text { CMLTV } \\
\text { DRAIN } \\
\text { Cm }\end{array}$ & $\begin{array}{l}\text { TRITIUM } \\
\text { CONC } \\
\mu \mathrm{Ci} / \mathrm{L}\end{array}$ & $\begin{array}{c}\mu \mathrm{Ci} \\
\text { RELEASED }\end{array}$ & $\begin{array}{c}\text { CMLTV } \\
\text { RELEASED } \\
{ }_{\mu} \mathrm{Ci}\end{array}$ \\
\hline $\begin{array}{r}11-16-84 \\
1-24-85 \\
2-13-85 \\
3-11-85 \\
3-12-85 \\
3-29-85 \\
4-04-85 \\
4-12-85 \\
6-20-85 \\
7-23-85 \\
8-14-85 \\
10-24-85 \\
1-30-86 \\
2-22-86 \\
2-28-86 \\
3-07-86 \\
3-13-86 \\
3-21-86 \\
3-28-86 \\
4-03-86 \\
4-10-86 \\
4-17-86 \\
4-25-86 \\
5-01-86 \\
5-08-86 \\
5-15-86 \\
5-22-86 \\
5-29-86 \\
6-06-86 \\
6-09-86 \\
6-12-86 \\
6-19-86 \\
6-26-86 \\
7-03-86 \\
7-10-86 \\
7-17-86 \\
7-24-86 \\
0-07\end{array}$ & $\begin{array}{l}300.0 \\
321.0 \\
390.0 \\
410.0 \\
436.0 \\
437.0 \\
454.0 \\
460.0 \\
468.0 \\
537.0 \\
570.0 \\
592.0 \\
663.0 \\
761.0 \\
784.0 \\
790.0 \\
797.0 \\
803.0 \\
811.0 \\
818.0 \\
824.0 \\
831.0 \\
838.0 \\
846.0 \\
852.0 \\
859.0 \\
866.0 \\
873.0 \\
880.0 \\
888.0 \\
891.0 \\
894.0 \\
901.0 \\
908.0 \\
915.0 \\
922.0 \\
929.0 \\
936.0 \\
951.0 \\
956.0 \\
971.0\end{array}$ & $\begin{array}{r}58.0 \\
14.0 \\
9.0 \\
13.0 \\
9.0 \\
9.7 \\
7.5 \\
9.5 \\
9.8 \\
7.4 \\
8.0 \\
9.4\end{array}$ & $\begin{array}{l}0.04 \\
0.05 \\
0.05 \\
0.05 \\
0.05 \\
0.05 \\
0.05 \\
0.05 \\
0.05 \\
1.96 \\
1.96 \\
3.01 \\
3.93 \\
5.01 \\
5.01 \\
6.95 \\
6.95 \\
6.95 \\
9.15 \\
9.68 \\
10.02 \\
10.52 \\
10.86 \\
11.23 \\
11.52 \\
11.88 \\
12.25 \\
12.53 \\
12.83 \\
13.19 \\
13.19 \\
13.40 \\
13.66 \\
13.92 \\
14.19 \\
14.41 \\
14.60 \\
14.78 \\
14.88 \\
15.16 \\
15.48\end{array}$ & $\begin{array}{l}4.020 \\
5.160\end{array}$ & $\begin{array}{r}250.56 \\
60.48 \\
38.88 \\
56.16 \\
38.88 \\
33.76 \\
22.61 \\
28.64 \\
29.55 \\
22.31 \\
24.12 \\
23.97\end{array}$ & $\begin{array}{r}0.19 \\
0.22 \\
0.22 \\
0.22 \\
0.22 \\
0.22 \\
0.22 \\
0.22 \\
0.22 \\
105.41 \\
105.41 \\
163.46 \\
260.74 \\
407.80 \\
407.80 \\
627.26 \\
627.26 \\
627.26 \\
877.82 \\
938.30 \\
977.18 \\
1033.34 \\
1072.22 \\
1105.97 \\
1128.59 \\
1157.23 \\
1186.77 \\
1209.09 \\
1233.21 \\
1257.18 \\
1257.18 \\
1271.96 \\
1289.65 \\
1308.48 \\
1328.05 \\
1344.64 \\
1358.76 \\
1371.88 \\
1378.71 \\
1397.83 \\
1418.74 \\
1436.99\end{array}$ \\
\hline
\end{tabular}


Lysimeter \#1 field radiochemistry (continued) Masonry Cement

Boric Acid Concentrate

Drum 4-1

\begin{tabular}{rrrrrrr} 
& & \multicolumn{4}{c}{ CMLTV TRITIUM TOTAL } & \multicolumn{2}{c}{ CMLTV } \\
DATE & DAY & DRAIN & \multicolumn{2}{c}{ DRAIN CONC } & RELEASED RELEASED \\
& & L & Cm & $\mu C i / L$ & $\mu C i$ & $\mu C i$ \\
$9-25-86$ & 999.0 & 6.6 & 16.00 & 2.450 & 16.17 & 1453.16 \\
$10-02-86$ & 1006.0 & 5.1 & 16.19 & 2.450 & 12.50 & 1465.65 \\
$10-23-86$ & 1027.0 & 5.2 & 16.39 & 3.380 & 17.58 & 1483.23 \\
$11-06-86$ & 1041.0 & 3.1 & 16.51 & 5.630 & 17.45 & 1500.68 \\
$11-20-86$ & 1055.0 & 2.6 & 16.61 & 2.340 & 6.08 & 1506.77 \\
$12-10-86$ & 1075.0 & 2.5 & 16.70 & 2.430 & 6.08 & 1512.84 \\
$12-30-86$ & 1095.0 & 3.2 & 16.82 & 2.520 & 8.06 & 1520.91 \\
$1-13-87$ & 1109.0 & 1.6 & 16.88 & 2.630 & 4.21 & 1525.11 \\
$1-26-87$ & 1122.0 & 1.5 & 16.94 & 4.590 & 6.89 & 1532.00 \\
$2-09-87$ & 1136.0 & 1.3 & 16.99 & 5.630 & 7.32 & 1539.32 \\
$3-09-87$ & 1164.0 & 2.4 & 17.08 & 2.760 & 6.69 & 1546.01 \\
$3-23-87$ & 1178.0 & 1.6 & 17.14 & 2.140 & 3.32 & 1549.33 \\
$4-07-87$ & 1193.0 & 1.8 & 17.21 & 2.540 & 4.64 & 1553.96 \\
$4-21-87$ & 1207.0 & 4.6 & 17.38 & 2.280 & 10.37 & 1564.34 \\
$5-08-87$ & 1224.0 & 7.3 & 17.66 & 2.270 & 16.63 & 1580.96 \\
$5-27-87$ & 1243.0 & 9.2 & 18.01 & 3.980 & 36.62 & 1617.58
\end{tabular}


Lysimeter \#7 field radiochemistry Masonry Cement Boric Acid Concentrate Drum 4-2

\begin{tabular}{|c|c|c|c|c|c|c|}
\hline DATE & DAY & $\begin{array}{c}\text { ORAIN } \\
L\end{array}$ & $\begin{array}{l}\text { CMLTV } \\
\text { DRAIN } \\
\text { Cm }\end{array}$ & $\begin{array}{l}\text { TRITIUM } \\
\text { CONC } \\
\mu \mathrm{Ci} / \mathrm{L}\end{array}$ & $\begin{array}{l}\text { TOTAL } \\
\text { RELEASED } \\
\quad \mu \mathrm{Ci}\end{array}$ & $\begin{array}{c}\text { CMLTV } \\
\text { RELEASED } \\
\quad \mu C j\end{array}$ \\
\hline $\begin{array}{r}10-26-84 \\
1-24-85 \\
2-13-85 \\
3-11-85 \\
3-12-85 \\
3-29-85 \\
4-04-85 \\
4-12-85 \\
6-20-85 \\
7-23-85 \\
8-14-85 \\
10-24-85 \\
1-30-86 \\
2-22-86 \\
2-28-86 \\
3-07-86 \\
3-13-86 \\
3-21-86 \\
3-28-86 \\
4-03-86 \\
4-10-86 \\
4-17-86 \\
4-25-86 \\
5-01-86 \\
5-08-86 \\
5-15-86 \\
5-22-86 \\
5-29-86 \\
6-06-86 \\
6-09-86 \\
6-12-86 \\
6-19-86 \\
6-26-86 \\
7-03-86 \\
7-10-86 \\
7-17-86 \\
7-24-86 \\
8-07-86 \\
8-13-86 \\
8-28-86 \\
9-10-86 \\
9-25-86\end{array}$ & $\begin{array}{l}300.0 \\
390.0 \\
410.0 \\
436.0 \\
437.0 \\
454.0 \\
460.0 \\
468.0 \\
537.0 \\
570.0 \\
592.0 \\
663.0 \\
761.0 \\
784.0 \\
790.0 \\
797.0 \\
803.0 \\
811.0 \\
818.0 \\
824.0 \\
831.0 \\
838.0 \\
846.0 \\
852.0 \\
859.0 \\
866.0 \\
873.0 \\
880.0 \\
888.0 \\
891.0 \\
894.0 \\
901.0 \\
908.0 \\
915.0 \\
922.0 \\
929.0 \\
936.0 \\
951.0 \\
956.0 \\
971.0 \\
984.0 \\
999.0\end{array}$ & $\begin{array}{r}67.245 \\
27.398 \\
24.712 \\
32.283 \\
26.000 \\
100.000 \\
32.000 \\
14.000 \\
14.000 \\
11.000 \\
9.000 \\
9.355 \\
8.390 \\
7.480 \\
9.000 \\
7.665 \\
6.480 \\
9.050\end{array}$ & $\begin{array}{l}0.03 \\
0.03 \\
0.03 \\
0.03 \\
0.03 \\
0.36 \\
0.36 \\
0.36 \\
2.92 \\
2.92 \\
3.96 \\
4.90 \\
6.12 \\
6.12 \\
7.11 \\
7.11 \\
10.91 \\
12.13 \\
12.66 \\
13.20 \\
13.61 \\
13.96 \\
14.31 \\
14.63 \\
14.92 \\
15.26 \\
15.55 \\
15.80 \\
16.14 \\
16.14 \\
16.35 \\
16.60 \\
16.85 \\
17.09 \\
17.28 \\
17.45 \\
17.64 \\
17.77 \\
18.02 \\
18.25 \\
18.47 \\
18.67\end{array}$ & $\begin{array}{l}2.440 \\
2.560\end{array}$ & $\begin{array}{r}351.00 \\
112.32 \\
49.14 \\
49.14 \\
38.61 \\
31.59 \\
25.45 \\
22.19 \\
19.78 \\
23.81 \\
20.27 \\
17.14 \\
23.26\end{array}$ & $\begin{array}{r}0.06 \\
0.07 \\
0.07 \\
0.07 \\
0.07 \\
24.84 \\
24.84 \\
24.84 \\
251.45 \\
251.45 \\
355.98 \\
461.25 \\
600.07 \\
600.07 \\
691.33 \\
691.33 \\
1042.33 \\
1154.65 \\
1203.79 \\
1252.93 \\
1291.54 \\
1323.13 \\
1348.57 \\
1370.76 \\
1390.55 \\
1414.35 \\
1434.63 \\
1451.77 \\
1475.02 \\
1475.02 \\
1489.10 \\
1505.69 \\
1521.35 \\
1536.90 \\
1549.70 \\
1559.58 \\
1568.66 \\
1577.08 \\
1591.07 \\
1602.35 \\
1615.20 \\
1627.05\end{array}$ \\
\hline
\end{tabular}


Lysimeter \#7 field radiochemistry (continued)

Masonry Cement

Boric Acid Concentrate

Drum 4-2

\begin{tabular}{|c|c|c|c|c|c|c|}
\hline DATE & DAY & $\begin{array}{c}\text { DRAIN } \\
L\end{array}$ & $\begin{array}{l}\text { CML TV } \\
\text { DRAIN } \\
\text { Cm }\end{array}$ & $\begin{array}{l}\text { TRI TIUM } \\
\text { CONC } \\
\mu \mathrm{Ci} / \mathrm{L}\end{array}$ & $\begin{array}{l}\text { TOTAL } \\
\text { RELEASED } \\
\quad \mu C i\end{array}$ & $\begin{array}{c}\text { CMLTV } \\
\text { RELEASED } \\
\quad \mu C i\end{array}$ \\
\hline $\begin{array}{r}10-02-86 \\
10-23-86 \\
11-06-86 \\
1-20-86 \\
12-10-86 \\
12-30-86 \\
1-13-87 \\
1-26-87 \\
2-09-87 \\
3-09-87 \\
3-23-87 \\
4-07-87 \\
4-21-87 \\
5-08-87 \\
5-27-87\end{array}$ & $\begin{array}{l}1027.0 \\
1041.0 \\
1055.0 \\
1075.0 \\
1095.0 \\
1109.0 \\
1122.0 \\
1136.0 \\
1164.0 \\
1178.0 \\
1193.0 \\
1207.0\end{array}$ & $\begin{array}{l}3.500 \\
4.100 \\
3.120 \\
2.525 \\
2.925 \\
3.150 \\
2.025 \\
1.800 \\
1.650 \\
3.950 \\
2.250 \\
3.125 \\
4.150 \\
6.650 \\
3.600\end{array}$ & $\begin{array}{l}18.80 \\
18.96 \\
19.08 \\
19.17 \\
19.28 \\
19.40 \\
19.48 \\
19.55 \\
19.61 \\
19.76 \\
19.85 \\
19.97 \\
20.12 \\
20.38 \\
20.51\end{array}$ & $\begin{array}{l}1.970 \\
2.950 \\
5.180 \\
2.230 \\
2.180 \\
2.230 \\
2.230 \\
4.280 \\
5.410 \\
2.400 \\
2.820 \\
2.810 \\
2.980 \\
4.470\end{array}$ & $\begin{array}{r}6.90 \\
12.10 \\
16.16 \\
5.63 \\
6.38 \\
7.02 \\
4.52 \\
7.70 \\
8.93 \\
9.48 \\
6.35 \\
8.78 \\
12.37 \\
29.73 \\
16.09\end{array}$ & $\begin{array}{l}1633.95 \\
1646.04 \\
1662.20 \\
1667.83 \\
1674.21 \\
1681.23 \\
1685.75 \\
1693.45 \\
1702.38 \\
1711.86 \\
1718.21 \\
1726.99 \\
1739.35 \\
1769.08 \\
1785.17\end{array}$ \\
\hline
\end{tabular}


Lysimeter \#2 field radiochemistry Portland III Cement $\mathrm{Na}_{2} \mathrm{SO}_{4}$ Evaporator Concentrate

Drum 1-1

$\begin{array}{rrrrrrrr}\text { DATE } & \text { OAY } & \text { ORAIN } & \text { ORAIN } & \text { CONC } & \text { RELEASED } & \text { RELEASED } \\ & & \text { L } & \text { Cm } & \mu C i / L & \mu C i & \mu C i \\ 10-26-84 & 300.0 & 1.070 & 0.04 & 0.000 & & 0.00 \\ 11-16-84 & 321.0 & 0.175 & 0.05 & & & 0.00 \\ 1-24-85 & 390.0 & 0.210 & 0.06 & & & 0.00 \\ 2-13-85 & 410.0 & 0.000 & 0.06 & 0.000 & & 0.00 \\ 3-11-85 & 436.0 & & 0.06 & & & 0.00 \\ 3-12-85 & 437.0 & & 0.06 & & & 0.00 \\ 3-29-85 & 454.0 & 16.141 & 0.67 & 0.000 & & 0.00 \\ 4-04-85 & 460.0 & & 0.67 & & & 0.00 \\ 4-12-85 & 468.0 & & 0.67 & & & 0.00 \\ 6-20-85 & 537.0 & 57.781 & 2.87 & 0.000 & & 0.00 \\ 7-23-85 & 570.0 & & 2.87 & & & 0.00 \\ 8-14-85 & 592.0 & 29.391 & 3.98 & & 0.36 & 0.36 \\ 10-24-85 & 663.0 & 23.712 & 4.88 & 0.024 & 0.57 & 0.93 \\ 1-30-86 & 761.0 & 17.142 & 5.54 & 0.001 & 0.01 & 0.94 \\ 2-22-86 & 784.0 & & 5.54 & & & 0.94 \\ 2-28-86 & 790.0 & 40.500 & 7.08 & & 0.86 & 1.80 \\ 3-07-86 & 797.0 & & 7.08 & & & 1.80 \\ 3-13-86 & 803.0 & & 7.08 & & & 1.80 \\ 3-21-86 & 811.0 & 62.000 & 9.43 & & 1.32 & 3.12 \\ 3-28-86 & 818.0 & 14.000 & 9.97 & & 0.30 & 3.42 \\ 4-03-86 & 824.0 & 10.000 & 10.35 & & 0.21 & 3.63 \\ 4-10-86 & 831.0 & 11.000 & 10.76 & & 0.23 & 3.87 \\ 4-17-86 & 838.0 & 9.000 & 11.11 & & 0.19 & 4.06 \\ 4-25-86 & 846.0 & 10.460 & 11.50 & 0.042 & 0.44 & 4.50 \\ 5-01-86 & 852.0 & 7.050 & 11.77 & & 0.36 & 4.85 \\ 5-08-86 & 859.0 & 9.200 & 12.12 & & 0.46 & 5.31 \\ 5-15-86 & 866.0 & 8.735 & 12.45 & & 0.44 & 5.75 \\ 5-22-86 & 873.0 & 7.435 & 12.74 & & 0.37 & 6.13 \\ 5-29-86 & 880.0 & 7.490 & 13.02 & & 0.38 & 6.51 \\ 6-06-86 & 888.0 & 8.215 & 13.33 & 0.059 & 0.48 & 6.99 \\ 6-09-86 & 891.0 & & 13.33 & & & 6.99 \\ 6-12-86 & 894.0 & 5.540 & 13.54 & & 0.31 & 7.30 \\ 6-19-86 & 901.0 & 6.980 & 13.81 & & 0.39 & 7.68 \\ 6-26-86 & 908.0 & 7.290 & 14.09 & 0.052 & 0.38 & 8.06 \\ 7-03-86 & 915.0 & 7.600 & 14.38 & & 0.70 & 8.75 \\ 7-10-86 & 922.0 & 6.140 & 14.61 & 0.132 & 0.81 & 9.56 \\ 7-17-86 & 929.0 & 5.380 & 14.81 & & 0.78 & 10.34 \\ 7-24-86 & 936.0 & 4.800 & 15.00 & 0.157 & 0.75 & 11.09 \\ 8-07-86 & 951.0 & 3.900 & 15.14 & & 0.62 & 11.71 \\ 8-13-86 & 956.0 & 7.440 & 15.43 & 0.160 & 1.19 & 12.90 \\ 8-28-86 & 971.0 & 7.900 & 15.73 & 0.115 & 0.91 & 13.81 \\ 9-10-86 & 984.0 & 7.260 & 16.00 & 0.108 & 0.79 & 14.60\end{array}$


Lysimeter \#2 field radiochemistry (continued)

Portland III Cement

$\mathrm{Na}_{2} \mathrm{SO}_{4}$ Evaporator Concentrate

Drum 1-1

\begin{tabular}{|c|c|c|c|c|c|c|}
\hline DATE & DAY & $\begin{array}{c}\text { DRAIN } \\
L\end{array}$ & $\begin{array}{c}\text { CMLTV } \\
\text { DRAIN } \\
\text { Cm }\end{array}$ & $\begin{array}{l}\text { COBALT } \\
\text { CONC } \\
\mu \mathrm{Ci} / \mathrm{L}\end{array}$ & $\begin{array}{l}\text { TOTAL } \\
\text { RELEASED } \\
\qquad \mathrm{\mu C} i\end{array}$ & $\begin{array}{l}\text { CMLTV } \\
\text { RELEASED } \\
\quad \mu \mathrm{C} i\end{array}$ \\
\hline $\begin{array}{r}9-25-86 \\
10-02-86 \\
10-23-86 \\
11-06-86 \\
11-20-86 \\
12-10-86 \\
12-30-86 \\
1-13-87\end{array}$ & $\begin{array}{r}999.0 \\
1006.0 \\
1027.0 \\
1041.0 \\
1055.0 \\
1075.0 \\
1095.0 \\
1109.0\end{array}$ & $\begin{array}{l}6.810 \\
5.100 \\
4.620 \\
4.160 \\
3.350 \\
3.750 \\
3.250 \\
2.100 \\
1.800\end{array}$ & $\begin{array}{l}16.46 \\
16.63 \\
16.79 \\
16.92 \\
17.06 \\
17.18 \\
17.26 \\
17.33 \\
17.39\end{array}$ & $\begin{array}{l}0.097 \\
0.092 \\
0.094 \\
0.131 \\
0.082 \\
0.071 \\
0.071 \\
0.432 \\
0.071 \\
0.061\end{array}$ & $\begin{array}{l}0.66 \\
0.47 \\
0.43 \\
0.54 \\
0.28 \\
0.27 \\
0.23 \\
0.91 \\
0.13 \\
0.10\end{array}$ & $\begin{array}{l}15.26 \\
15.73 \\
16.16 \\
16.71 \\
16.98 \\
17.25 \\
17.48 \\
18.39 \\
18.51 \\
18.61\end{array}$ \\
\hline
\end{tabular}


Lysimeter $\# 8$ field radiochemistry

Portland III Cement

$\mathrm{Na}_{2} \mathrm{SO}_{4}$ Evaporator Concentrate

Drum 1-2

\begin{tabular}{|c|c|c|c|c|c|c|}
\hline DATE & DAY & $\begin{array}{c}\text { DRAIN } \\
\mathrm{L}\end{array}$ & $\begin{array}{l}\text { CMLTV } \\
\text { DRAIN } \\
\text { CI }\end{array}$ & $\begin{array}{c}\text { COBALT } \\
\text { CONC } \\
\mu \mathrm{Ci} / \mathrm{L}\end{array}$ & $\begin{array}{l}\text { TOTAL } \\
\text { RELEASED } \\
\quad \mu \mathrm{C} i\end{array}$ & $\begin{array}{c}\text { CMLTV } \\
\text { RELEASED } \\
\qquad \mu \mathrm{Ci}\end{array}$ \\
\hline $\begin{array}{r}10-26-84 \\
11-16-84 \\
1-24-85 \\
2-13-85 \\
3-11-85 \\
3-12-85 \\
3-29-85 \\
4-04-85 \\
4-12-85 \\
6-20-85 \\
7-23-85 \\
8-14-85 \\
10-24-85 \\
1-30-86 \\
2-22-86 \\
2-28-86 \\
3-07-86 \\
3-13-86 \\
3-21-86 \\
3-28-86 \\
4-03-86 \\
4-10-86 \\
4-17-86 \\
4-25-86 \\
5-01-86 \\
5-08-86 \\
5-15-86 \\
5-22-86 \\
5-29-86 \\
6-06-86 \\
6-09-86 \\
6-12-86 \\
6-19-86 \\
6-26-86 \\
7-03-86 \\
7-10-86 \\
7-17-86 \\
7-24-86 \\
8-07-86 \\
8-13-86 \\
8-28-86 \\
9-10-86\end{array}$ & $\begin{array}{l}300.0 \\
321.0 \\
390.0 \\
410.0 \\
436.0 \\
437.0 \\
454.0 \\
460.0 \\
468.0 \\
537.0 \\
570.0 \\
592.0 \\
663.0 \\
761.0 \\
784.0 \\
790.0 \\
797.0 \\
803.0 \\
811.0 \\
818.0 \\
824.0 \\
831.0 \\
838.0 \\
846.0 \\
852.0 \\
859.0 \\
866.0 \\
873.0 \\
880.0 \\
888.0 \\
891.0 \\
894.0 \\
901.0 \\
908.0 \\
915.0 \\
922.0 \\
929.0 \\
936.0 \\
951.0 \\
956.0 \\
971.0 \\
984.0\end{array}$ & $\begin{array}{r}55.888 \\
23.712 \\
18.034 \\
36.069 \\
82.000 \\
14.000 \\
\\
30.000 \\
12.000 \\
19.000 \\
14.500 \\
11.000 \\
9.000 \\
9.740 \\
7.485 \\
8.260 \\
8.680 \\
7.225 \\
7.825 \\
10.375 \\
\\
5.900 \\
7.720 \\
7.560 \\
7.400 \\
5.680 \\
5.920 \\
4.680 \\
3.840 \\
7.580 \\
7.300 \\
6.360\end{array}$ & $\begin{array}{l}0.03 \\
0.03 \\
0.03 \\
6.62 \\
11.41 \\
12.92 \\
14.11 \\
14.11 \\
14.11 \\
16.23 \\
16.23 \\
17.13 \\
17.82 \\
19.19 \\
22.31 \\
22.84 \\
22.84 \\
23.98 \\
24.44 \\
25.16 \\
25.71 \\
26.13 \\
26.47 \\
26.84 \\
27.13 \\
27.44 \\
27.77 \\
28.04 \\
28.34 \\
28.74 \\
28.74 \\
28.96 \\
29.25 \\
29.54 \\
29.82 \\
30.04 \\
30.26 \\
30.44 \\
30.59 \\
30.88 \\
31.15 \\
31.40\end{array}$ & $\begin{array}{l}0.000 \\
0.001\end{array}$ & $\begin{array}{l}1.45 \\
0.58 \\
0.92 \\
0.70 \\
0.53 \\
0.44 \\
0.51 \\
0.55 \\
0.60 \\
0.63 \\
0.53 \\
0.57 \\
0.98\end{array}$ & $\begin{array}{r}0.00 \\
0.00 \\
0.00 \\
0.29 \\
0.39 \\
0.39 \\
0.41 \\
0.41 \\
0.41 \\
0.54 \\
0.54 \\
0.80 \\
1.15 \\
2.76 \\
6.72 \\
7.40 \\
7.40 \\
8.85 \\
9.43 \\
10.35 \\
11.05 \\
11.58 \\
12.01 \\
12.52 \\
13.07 \\
13.68 \\
14.31 \\
14.84 \\
15.41 \\
16.39 \\
16.39 \\
16.84 \\
17.43 \\
17.88 \\
18.54\end{array}$ \\
\hline
\end{tabular}




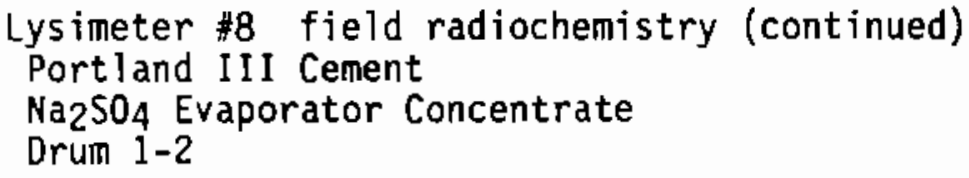

\begin{tabular}{|c|c|c|c|c|c|c|}
\hline DATE & DAY & $\begin{array}{c}\text { DRAIN } \\
L\end{array}$ & $\begin{array}{l}\text { CMLTV } \\
\text { DRAIN } \\
\mathrm{Cm}\end{array}$ & $\begin{array}{c}\text { COBALT } \\
\text { CONC } \\
\mu \mathrm{Cj} / \mathrm{L}\end{array}$ & $\begin{array}{l}\text { TOTAL } \\
\text { RELEASED } \\
\quad \mu \mathrm{C} i\end{array}$ & $\begin{array}{c}\text { CMLTV } \\
\text { RELEASED } \\
\mu \mathrm{\mu Ci}\end{array}$ \\
\hline $\begin{array}{r}9-25-86 \\
10-02-86 \\
10-23-86 \\
11-06-86 \\
11-20-86 \\
12-10-86 \\
12-30-86 \\
1-13-87 \\
1-26-87 \\
2-09-87\end{array}$ & $\begin{array}{r}999.0 \\
1006.0 \\
1027.0 \\
1041.0 \\
1055.0 \\
1075.0 \\
1095.0 \\
1109.0 \\
1122.0 \\
1136.0\end{array}$ & $\begin{array}{l}6.180 \\
4.900 \\
4.700 \\
3.760 \\
3.050 \\
3.300 \\
3.100 \\
1.800 \\
1.550 \\
1.350\end{array}$ & $\begin{array}{l}31.63 \\
31.82 \\
32.00 \\
32.14 \\
32.25 \\
32.38 \\
32.50 \\
32.57 \\
32.62 \\
32.68\end{array}$ & $\begin{array}{l}0.116 \\
0.272 \\
0.142 \\
0.127 \\
0.568 \\
0.091 \\
0.619 \\
0.097 \\
0.092 \\
0.086\end{array}$ & $\begin{array}{l}0.72 \\
1.33 \\
0.67 \\
0.48 \\
1.73 \\
0.30 \\
1.92 \\
0.18 \\
0.14 \\
0.12\end{array}$ & \\
\hline
\end{tabular}


Lysimeter \#3 field radiochemistry

Portland III Cement

$\mathrm{Na}_{2} \mathrm{SO}_{4}$ Evaporator Concentrate w/ Resin

Drum 2-1

$\begin{array}{rcccccc}\text { DATE } & \text { DAY } & \text { DRAIN } & \text { DRAIN } & \text { CONC } & \text { TOTAL } & \text { CMLTV } \\ & & \text { L } & \text { Cm } & \mu C i / L & \mu C i & \mu C i \\ 10-26-84 & 300.0 & 0.850 & 0.03 & 0.000 & 0.00 & 0.00 \\ 11-16-84 & 321.0 & 0.850 & 0.06 & & 0.00 & 0.00 \\ 1-24-85 & 390.0 & 0.691 & 0.09 & 0.000 & 0.00 & 0.00 \\ 2-13-85 & 410.0 & 0.000 & 0.09 & & 0.00 & 0.00 \\ 3-11-85 & 436.0 & & 0.09 & & & 0.00 \\ 3-12-85 & 437.0 & & 0.09 & & & 0.00 \\ 3-29-85 & 454.0 & 1.400 & 0.14 & 0.001 & .00 & .00 \\ 4-04-85 & 460.0 & & 0.14 & & & .00 \\ 4-12-85 & 468.0 & & 0.14 & & & .00 \\ 6-20-85 & 537.0 & 50.210 & 2.05 & 0.004 & 0.19 & 0.19 \\ 7-23-85 & 570.0 & & 2.05 & & & 0.19 \\ 8-14-85 & 592.0 & 31.083 & 3.23 & & 0.06 & 0.26 \\ 10-24-85 & 663.0 & 19.927 & 3.99 & .000 & 0.01 & 0.26 \\ 1-30-86 & 761.0 & 24.712 & 4.93 & 0.087 & 2.14 & 2.40 \\ 2-22-86 & 784.0 & & 4.93 & & & 2.40 \\ 2-28-86 & 790.0 & 39.000 & 6.41 & & 3.43 & 5.83 \\ 3-07-86 & 797.0 & & 6.41 & & & 5.83 \\ 3-13-86 & 803.0 & & 6.41 & & & 5.83 \\ 3-21-86 & 811.0 & 57.000 & 8.58 & & 5.01 & 10.84 \\ 3-28-86 & 818.0 & 15.000 & 9.15 & & 1.32 & 12.15 \\ 4-03-86 & 824.0 & 12.000 & 9.61 & & 1.05 & 13.21 \\ 4-10-86 & 831.0 & 11.000 & 10.03 & & 0.97 & 14.17 \\ 4-17-86 & 838.0 & 10.000 & 10.41 & & 0.88 & 15.05 \\ 4-25-86 & 846.0 & 10.000 & 10.79 & 0.089 & 0.89 & 15.94 \\ 5-01-86 & 852.0 & 6.730 & 11.04 & & 0.87 & 16.81 \\ 5-08-86 & 859.0 & 7.145 & 11.31 & & 0.92 & 17.73 \\ 5-15-86 & 866.0 & 9.850 & 11.69 & & 1.27 & 19.01 \\ 5-22-86 & 873.0 & 6.950 & 11.95 & & 0.90 & 19.90 \\ 5-29-86 & 880.0 & 8.755 & 12.29 & & 1.13 & 21.03 \\ 6-06-86 & 888.0 & 8.405 & 12.61 & 0.169 & 1.42 & 22.45 \\ 6-09-86 & 891.0 & & 12.61 & & & 22.45 \\ 6-12-86 & 894.0 & 5.040 & 12.80 & & 0.76 & 23.21 \\ 6-19-86 & 901.0 & 7.360 & 13.08 & & 1.11 & 24.33 \\ 6-26-86 & 908.0 & 7.480 & 13.36 & 0.133 & 0.99 & 25.32 \\ 7-03-86 & 915.0 & 7.600 & 13.65 & & 1.25 & 26.57 \\ 7-10-86 & 922.0 & 6.940 & 13.91 & 0.195 & 1.35 & 27.92 \\ 7-17-86 & 929.0 & 4.860 & 14.10 & & 1.01 & 28.93 \\ 7-24-86 & 936.0 & 4.720 & 14.28 & 0.221 & 1.04 & 29.97 \\ 8-07-86 & 951.0 & 4.140 & 14.44 & & 0.96 & 30.93 \\ 8-13-86 & 956.0 & 8.680 & 14.77 & 0.244 & 2.12 & 33.05 \\ 8-28-86 & 971.0 & 7.950 & 15.07 & 0.208 & 1.65 & 34.71 \\ 9-10-86 & 984.0 & 7.820 & 15.37 & 0.214 & 1.67 & 36.38\end{array}$




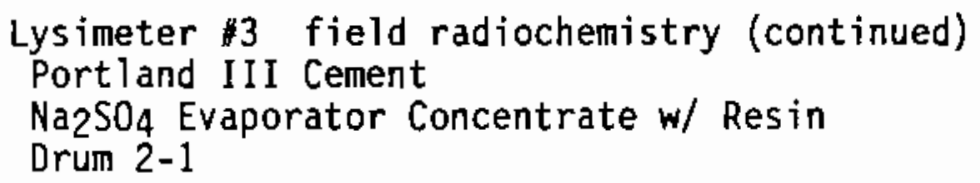

\begin{tabular}{|c|c|c|c|c|c|c|}
\hline DATE & DAY & $\begin{array}{c}\text { DRAIN } \\
L\end{array}$ & $\begin{array}{c}\text { CMLTV } \\
\text { DRAIN } \\
\text { Cm }\end{array}$ & $\begin{array}{c}\text { COBALT } \\
\text { CONC } \\
\mu \mathrm{Ci} / \mathrm{L}\end{array}$ & $\begin{array}{c}\text { TOTAL } \\
\text { RELEASED } \\
\boldsymbol{\mu} \boldsymbol{C} i\end{array}$ & $\begin{array}{c}\text { CMLTV } \\
\text { RELEASED } \\
\quad \mu C i\end{array}$ \\
\hline $\begin{array}{r}9-25-86 \\
10-02-86 \\
10-23-86 \\
11-06-86 \\
11-20-86 \\
12-10-86 \\
12-30-86 \\
1-13-87 \\
1-26-87 \\
2-09-87\end{array}$ & $\begin{array}{r}999.0 \\
1006.0 \\
1027.0 \\
1041.0 \\
1055.0 \\
1075.0 \\
1095.0 \\
1109.0 \\
1122.0 \\
1136.0\end{array}$ & $\begin{array}{l}6.520 \\
5.840 \\
5.280 \\
3.250 \\
3.100 \\
3.150 \\
3.050 \\
1.200 \\
1.750 \\
1.000\end{array}$ & $\begin{array}{l}15.61 \\
15.84 \\
16.04 \\
16.16 \\
16.28 \\
16.40 \\
16.51 \\
16.56 \\
16.63 \\
16.66\end{array}$ & $\begin{array}{l}0.249 \\
0.253 \\
0.227 \\
0.227 \\
0.228 \\
1.153 \\
1.037 \\
0.182 \\
1.007 \\
1.064\end{array}$ & $\begin{array}{l}1.62 \\
1.48 \\
1.20 \\
0.74 \\
0.71 \\
3.63 \\
3.16 \\
0.22 \\
1.76 \\
1.06\end{array}$ & $\begin{array}{l}38.00 \\
39.48 \\
40.67 \\
41.41 \\
42.12 \\
45.75 \\
48.91 \\
49.13 \\
50.89 \\
51.96\end{array}$ \\
\hline
\end{tabular}


Lysimeter \#9 field radiochemistry

Portland III Cement

$\mathrm{Na}_{2} \mathrm{SO}_{4}$ Evaporator Concentrate $w /$ Resin

Drum 2-2

\begin{tabular}{rrrrrrrr} 
& & & & & \\
DATE & DAY & \multicolumn{1}{c}{ DRAIN } & DRLTV & COBALT & TOTAL & CMLTV \\
& & L & CONC & RELEASED & RELEASED \\
& & & $\mu C i / L$ & $\mu C i$ & $\mu C i$ \\
$10-26-84$ & 300.0 & 1.090 & 0.04 & 0.000 & 0.00 & 0.00 \\
$11-16-84$ & 321.0 & 0.260 & 0.05 & & .00 & .00 \\
$1-24-85$ & 390.0 & 0.010 & 0.05 & & .00 & .00 \\
$2-13-85$ & 410.0 & 199.734 & 7.65 & 0.001 & 0.11 & 0.11 \\
$3-11-85$ & 436.0 & 120.240 & 12.22 & & 0.17 & 0.28 \\
$3-12-85$ & 437.0 & 19.873 & 12.97 & 0.002 & 0.05 & 0.33 \\
$3-29-85$ & 454.0 & 23.712 & 13.87 & & 1.45 & 1.78 \\
$4-04-85$ & 460.0 & & 13.87 & & & 1.78 \\
$4-12-85$ & 468.0 & & 13.87 & & & 1.78 \\
$6-20-85$ & 537.0 & 48.318 & 15.71 & & 2.96 & 4.73 \\
$7-23-85$ & 570.0 & & 15.71 & & & 4.73 \\
$8-14-85$ & 592.0 & 26.551 & 16.72 & & 1.62 & 6.36 \\
$10-24-85$ & 663.0 & 20.873 & 17.51 & 0.120 & 2.50 & 8.86 \\
$1-30-86$ & 761.0 & 13.910 & 18.04 & 0.188 & 2.62 & 11.48 \\
$2-22-86$ & 784.0 & 113.000 & 22.34 & & 16.39 & 27.86 \\
$2-28-86$ & 790.0 & 23.000 & 23.21 & & 3.34 & 31.20 \\
$3-07-86$ & 797.0 & & 23.21 & & & 31.20 \\
$3-13-86$ & 803.0 & 0.000 & 23.21 & & 0.00 & 31.20 \\
$3-21-86$ & 811.0 & 4.000 & 23.37 & & 0.58 & 31.78 \\
$3-28-86$ & 818.0 & 17.000 & 24.01 & & 2.47 & 34.24 \\
$4-03-86$ & 824.0 & 12.500 & 24.49 & & 1.81 & 36.06 \\
$4-10-86$ & 831.0 & 11.000 & 24.91 & & 1.60 & 37.65 \\
$4-17-86$ & 838.0 & 10.000 & 25.29 & & 1.45 & 39.10 \\
$4-25-86$ & 846.0 & 8.600 & 25.61 & 0.102 & 0.88 & 39.98 \\
$5-01-86$ & 852.0 & 6.950 & 25.88 & & 0.96 & 40.93 \\
$5-08-86$ & 859.0 & 7.345 & 26.16 & & 1.01 & 41.94 \\
$5-15-86$ & 866.0 & 7.430 & 26.44 & & 1.02 & 42.97 \\
$5-22-86$ & 873.0 & 6.210 & 26.67 & & 0.85 & 43.82 \\
$5-29-86$ & 880.0 & 6.830 & 26.93 & & 0.94 & 44.76 \\
$6-06-86$ & 888.0 & 8.000 & 27.24 & 0.173 & 1.38 & 46.14 \\
$6-09-86$ & 891.0 & & 27.24 & & & 46.14 \\
$6-12-86$ & 894.0 & 5.445 & 27.45 & & 1.37 & 47.51 \\
$6-19-86$ & 901.0 & 6.840 & 27.71 & & 1.72 & 49.24 \\
$6-26-86$ & 908.0 & 7.250 & 27.98 & 0.331 & 2.40 & 51.64 \\
$7-03-86$ & 915.0 & 7.660 & 28.27 & & 2.54 & 54.18 \\
$7-10-86$ & 922.0 & 6.180 & 28.51 & 0.333 & 2.06 & 56.24 \\
$7-17-86$ & 929.0 & 5.360 & 28.71 & & 1.43 & 57.67 \\
$7-24-86$ & 936.0 & 4.660 & 28.89 & & 1.25 & 58.92 \\
$8-07-86$ & 951.0 & 3.960 & 29.04 & & 1.06 & 59.97 \\
$8-13-86$ & 956.0 & 7.840 & 29.34 & 0.201 & 1.58 & 61.55 \\
$8-28-86$ & 971.0 & 7.320 & 29.62 & 0.195 & 1.43 & 62.98 \\
$9-10-86$ & 984.0 & 6.700 & 29.87 & 0.187 & 1.25 & 64.23
\end{tabular}


Lysimeter \#9 field radiochemistry (continued)

Portland III Cement

$\mathrm{Na}_{2} \mathrm{SO}_{4}$ Evaporator Concentrate w/ Res in

Drum 2-2

\begin{tabular}{|c|c|c|c|c|c|c|}
\hline DATE & DAY & $\begin{array}{c}\text { DRAIN } \\
L\end{array}$ & $\begin{array}{l}\text { CMLTV } \\
\text { DRAIN } \\
\text { CI }\end{array}$ & $\begin{array}{c}\text { COBALT } \\
\text { CONC } \\
\mu \mathrm{Ci} / \mathrm{L}\end{array}$ & $\begin{array}{l}\text { TOTAL } \\
\text { RELEASED } \\
\quad \mu \mathrm{Ci}\end{array}$ & $\begin{array}{c}\text { CMLTV } \\
\text { RELEASED } \\
\quad \mu \mathrm{Ci}\end{array}$ \\
\hline $\begin{array}{l}9-25-86 \\
0-02-86 \\
0-23-86 \\
1-06-86 \\
1-20-86 \\
2-10-86 \\
2-30-86 \\
1-13-87 \\
1-26-87\end{array}$ & $\begin{array}{r}999.0 \\
1006.0 \\
1027.0 \\
1041.0 \\
1055.0 \\
1075.0 \\
1095.0 \\
1109.0 \\
1122.0 \\
1136.0\end{array}$ & $\begin{array}{l}6.320 \\
4.100 \\
4.100 \\
3.340 \\
2.700 \\
3.200 \\
2.700 \\
1.525 \\
1.225 \\
1.300\end{array}$ & $\begin{array}{l}30.11 \\
30.27 \\
30.42 \\
30.55 \\
30.65 \\
30.77 \\
30.88 \\
30.93 \\
30.98 \\
31.03\end{array}$ & $\begin{array}{l}0.246 \\
0.263 \\
0.233 \\
0.190 \\
0.162 \\
0.177 \\
0.191 \\
0.165 \\
0.176 \\
1.118\end{array}$ & $\begin{array}{l}1.55 \\
1.08 \\
0.95 \\
0.63 \\
0.44 \\
0.57 \\
0.51 \\
0.25 \\
0.22 \\
1.45\end{array}$ & \\
\hline
\end{tabular}


Lysimeter \#4 field radiochemistry

Dow Polymer

$\mathrm{Na}_{2} \mathrm{SO}_{4}$ Evaporator Concentrate w/ Resin

Drum 7-2

\begin{tabular}{|c|c|c|c|c|c|c|}
\hline DATE & DAY & $\begin{array}{c}\text { DRAIN } \\
L\end{array}$ & $\begin{array}{l}\text { CMLTV } \\
\text { DRAIN } \\
\text { CI }\end{array}$ & $\begin{array}{c}\text { COBALT } \\
\text { CONC } \\
\mu \mathrm{Ci} / \mathrm{L}\end{array}$ & $\begin{array}{l}\text { TOTAL } \\
\text { RELEASED } \\
\quad \mu C i\end{array}$ & $\begin{array}{l}\text { CMLTV } \\
\text { RELEASED } \\
\quad \mu \mathrm{C} i\end{array}$ \\
\hline $\begin{array}{r}10-26-84 \\
11-16-84 \\
1-24-85 \\
2-13-85 \\
3-11-85 \\
3-12-85 \\
3-29-85 \\
4-04-85 \\
4-12-85 \\
6-20-85 \\
7-23-85 \\
8-14-85 \\
10-24-85 \\
1-30-86 \\
2-22-86 \\
2-28-86 \\
3-07-86 \\
3-13-86 \\
3-21-86 \\
3-28-86 \\
4-03-86 \\
4-10-86 \\
4-17-86 \\
4-25-86 \\
5-01-86 \\
5-08-86 \\
5-15-86 \\
5-22-86 \\
5-29-86 \\
6-06-86 \\
6-09-86 \\
6-12-86 \\
6-19-86 \\
6-26-86 \\
7-03-86 \\
7-10-86 \\
7-17-86 \\
7-24-86 \\
8-07-86 \\
8-13-86 \\
8-28-86 \\
9-10-86\end{array}$ & $\begin{array}{l}300.0 \\
321.0 \\
390.0 \\
410.0 \\
436.0 \\
437.0 \\
454.0 \\
460.0 \\
468.0 \\
537.0 \\
570.0 \\
592.0 \\
663.0 \\
761.0 \\
784.0 \\
790.0 \\
797.0 \\
803.0 \\
811.0 \\
818.0 \\
824.0 \\
831.0 \\
838.0 \\
846.0 \\
852.0 \\
859.0 \\
866.0 \\
873.0 \\
880.0 \\
888.0 \\
891.0 \\
894.0 \\
901.0 \\
908.0 \\
915.0 \\
922.0 \\
929.0 \\
936.0 \\
951.0 \\
956.0 \\
971.0 \\
984.0\end{array}$ & $\begin{array}{r}55.000 \\
50.000 \\
\\
40.000 \\
14.000 \\
11.000 \\
10.000 \\
9.000 \\
4.600 \\
7.400 \\
8.425 \\
9.250 \\
7.220 \\
7.790 \\
7.990\end{array}$ & $\begin{array}{r}0.04 \\
0.04 \\
0.05 \\
0.05 \\
0.05 \\
0.05 \\
0.09 \\
0.09 \\
0.09 \\
2.28 \\
2.28 \\
3.33 \\
4.37 \\
5.31 \\
5.31 \\
7.41 \\
9.31 \\
9.31 \\
10.83 \\
11.36 \\
11.78 \\
12.16 \\
12.50 \\
12.67 \\
12.96 \\
13.28 \\
13.63 \\
13.90 \\
14.20 \\
14.50 \\
14.50 \\
14.71 \\
14.97 \\
15.23 \\
15.49 \\
15.72 \\
15.89 \\
16.08 \\
16.23 \\
16.54 \\
16.85 \\
17.14\end{array}$ & $\begin{array}{l}0.052 \\
0.050 \\
0.068\end{array}$ & $\begin{array}{l}0.06 \\
0.01 \\
1.36 \\
2.28 \\
2.07 \\
\\
1.66 \\
0.58 \\
0.46 \\
0.41 \\
0.37 \\
0.13 \\
0.19 \\
0.22 \\
0.24 \\
0.19 \\
0.21 \\
0.20\end{array}$ & $\begin{array}{r}0.00 \\
0.00 \\
0.00 \\
0.00 \\
0.00 \\
0.00 \\
.00 \\
.00 \\
.00 \\
0.22 \\
0.22 \\
0.28 \\
0.29 \\
1.64 \\
1.64 \\
3.92 \\
6.00 \\
6.00 \\
7.65 \\
8.23 \\
8.69 \\
9.10 \\
9.48 \\
9.61 \\
9.80 \\
10.02 \\
10.27 \\
10.46 \\
10.66 \\
10.86 \\
10.86 \\
11.00 \\
11.18 \\
11.36 \\
11.53 \\
11.67 \\
11.83 \\
12.07 \\
12.26 \\
12.69 \\
13.10 \\
13.61\end{array}$ \\
\hline
\end{tabular}




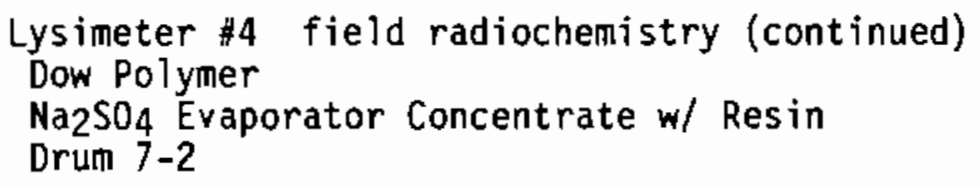

\begin{tabular}{|c|c|c|c|c|c|c|}
\hline DATE & DAY & $\begin{array}{c}\text { DRAIN } \\
\mathrm{L}\end{array}$ & $\begin{array}{c}\text { CMLTV } \\
\text { DRAIN } \\
\text { Cm }\end{array}$ & $\begin{array}{c}\text { COBALT } \\
\text { CONC } \\
\mu \mathrm{Ci} / \mathrm{L}\end{array}$ & $\begin{array}{l}\text { TOTAL } \\
\text { RELEASED } \\
\quad \mu \mathrm{Ci}\end{array}$ & $\begin{array}{c}\text { CMLTV } \\
\text { RELEASED } \\
\quad \mu \mathrm{Cj}\end{array}$ \\
\hline $\begin{array}{r}9-25-86 \\
10-02-86 \\
10-23-86 \\
11-06-86 \\
11-20-86 \\
12-10-86 \\
12-30-86 \\
1-13-87 \\
1-26-87 \\
2-09-87\end{array}$ & $\begin{array}{r}999.0 \\
1006.0 \\
1027.0 \\
1041.0 \\
1055.0 \\
1075.0 \\
1095.0 \\
1109.0 \\
1122.0 \\
1136.0\end{array}$ & $\begin{array}{l}7.180 \\
5.100 \\
6.100 \\
3.400 \\
3.550 \\
3.600 \\
3.550 \\
1.750 \\
2.125 \\
1.650\end{array}$ & $\begin{array}{l}17.41 \\
17.61 \\
17.84 \\
17.97 \\
18.10 \\
18.24 \\
18.37 \\
18.44 \\
18.52 \\
18.58\end{array}$ & $\begin{array}{l}0.061 \\
0.065 \\
0.075 \\
0.076 \\
0.066 \\
0.074 \\
0.077 \\
0.083 \\
0.472 \\
0.452\end{array}$ & $\begin{array}{l}0.44 \\
0.33 \\
0.45 \\
0.26 \\
0.24 \\
0.27 \\
0.27 \\
0.14 \\
1.00 \\
0.75\end{array}$ & $\begin{array}{l}14.05 \\
14.38 \\
14.84 \\
15.09 \\
15.33 \\
15.59 \\
15.87 \\
16.01 \\
17.02 \\
17.76\end{array}$ \\
\hline
\end{tabular}


Lysimeter $\# 10$ field radiochemistry

Dow Polymer

$\mathrm{Na}_{2} \mathrm{SO}_{4}$ Evaporator Concentrate w/ Resin

Drum 7-3

\begin{tabular}{|c|c|c|c|c|c|c|}
\hline DATE & DAY & $\begin{array}{c}\text { DRAIN } \\
\mathrm{L}\end{array}$ & $\begin{array}{c}\text { CMLTV } \\
\text { DRAIN } \\
\text { Cm }\end{array}$ & $\begin{array}{l}\text { COBALT } \\
\text { CONC } \\
\mu \mathrm{Ci} / \mathrm{L}\end{array}$ & $\begin{array}{l}\text { TOTAL } \\
\text { RELEASED } \\
\quad \mu \mathrm{Ci}\end{array}$ & $\begin{array}{l}\text { CMLTV } \\
\text { RELEASED } \\
\quad \mu \mathrm{Ci}\end{array}$ \\
\hline $\begin{array}{r}1 D-26-84 \\
11-16-84 \\
1-24-85 \\
2-13-85 \\
3-11-85 \\
3-12-85 \\
3-29-85 \\
4-04-85 \\
4-12-85 \\
6-20-85 \\
7-23-85 \\
8-14-85 \\
10-24-85 \\
1-30-86 \\
2-22-86 \\
2-28-86 \\
3-07-86 \\
3-13-86 \\
3-21-86 \\
3-28-86 \\
4-03-86 \\
4-10-86 \\
4-17-86 \\
4-25-86 \\
5-01-86 \\
5-08-86 \\
5-15-86 \\
5-22-86 \\
5-29-86 \\
6-06-86 \\
6-09-86 \\
6-12-86 \\
6-19-86 \\
6-26-86 \\
7-03-86 \\
7-10-86 \\
7-17-86 \\
7-24-86 \\
8-07-86 \\
8-13-86 \\
8-28-86 \\
9-10-86\end{array}$ & $\begin{array}{l}300.0 \\
321.0 \\
390.0 \\
410.0 \\
436.0 \\
437.0 \\
454.0 \\
460.0 \\
468.0 \\
537.0 \\
570.0 \\
592.0 \\
663.0 \\
761.0 \\
784.0 \\
790.0 \\
797.0 \\
803.0 \\
811.0 \\
818.0 \\
824.0 \\
831.0 \\
838.0 \\
846.0 \\
852.0 \\
859.0 \\
866.0 \\
873.0 \\
880.0 \\
888.0 \\
891.0 \\
894.0 \\
901.0 \\
908.0 \\
915.0 \\
922.0 \\
929.0 \\
936.0 \\
951.0 \\
956.0 \\
971.0 \\
984.0\end{array}$ & $\begin{array}{r}0.500 \\
147.631 \\
11.356 \\
0.000 \\
97.663\end{array}$ & $\begin{array}{r}0.00 \\
0.00 \\
.00 \\
0.49 \\
0.49 \\
0.49 \\
0.51 \\
6.12 \\
6.55 \\
6.55 \\
10.27 \\
10.27 \\
12.03 \\
12.40 \\
12.40 \\
12.40 \\
12.40 \\
12.40 \\
14.34 \\
18.33 \\
18.33 \\
18.33 \\
20.15 \\
20.39 \\
20.39 \\
21.23 \\
21.23 \\
21.23 \\
21.23 \\
21.23 \\
22.45 \\
22.45 \\
22.77 \\
23.18 \\
23.66 \\
23.66 \\
23.90 \\
24.09 \\
24.09 \\
24.50 \\
24.73 \\
24.92\end{array}$ & $\begin{array}{r}0.0 \\
0.001\end{array}$ & $\begin{array}{l}0.00 \\
0.00 \\
0.00 \\
0.00 \\
0.00 \\
0.00 \\
0.00\end{array}$ & $\begin{array}{l}0.00 \\
0.00 \\
.00 \\
.00 \\
.00 \\
.00 \\
.00 \\
.00 \\
.00 \\
.00 \\
.00 \\
.00 \\
.00 \\
.00 \\
.00 \\
.00 \\
.00 \\
.00 \\
.00 \\
0.01 \\
0.01 \\
0.01 \\
0.01 \\
0.02 \\
0.02 \\
0.04 \\
0.04 \\
0.04 \\
0.04 \\
0.04 \\
0.10 \\
0.10 \\
0.10 \\
0.11 \\
0.13 \\
0.13 \\
0.14 \\
0.15 \\
0.15 \\
0.16 \\
0.16 \\
0.16\end{array}$ \\
\hline
\end{tabular}


Lysimeter \#10 field radiochemistry (cont inued)

Dow Polymer

$\mathrm{Na}_{2} \mathrm{SO}_{4}$ Evaporator Concentrate w/ Resin

Drum 7-3

\begin{tabular}{|c|c|c|c|c|c|c|}
\hline DATE & DAY & $\begin{array}{c}\text { DRAIN } \\
\text { L }\end{array}$ & $\begin{array}{c}\text { CMLTV } \\
\text { DRAIN } \\
\text { CI }\end{array}$ & $\begin{array}{c}\text { COBALT } \\
\text { CONC } \\
\mu C i / L\end{array}$ & $\begin{array}{l}\text { TOTAL } \\
\text { RELEASED } \\
\quad \mu \mathrm{Ci}\end{array}$ & $\begin{array}{c}\text { CMLTV } \\
\text { RELEASEL } \\
\quad \mu C i\end{array}$ \\
\hline $\begin{array}{r}9-25-86 \\
10-02-86 \\
10-23-86 \\
11-06-86 \\
11-20-86 \\
11-10\end{array}$ & $\begin{array}{r}999.0 \\
1006.0 \\
1027.0 \\
1041.0 \\
1055.0 \\
1075.0 \\
1095.0\end{array}$ & $\begin{array}{l}6.600 \\
4.100 \\
4.000 \\
6.000\end{array}$ & $\begin{array}{l}25.17 \\
25.33 \\
25.48 \\
25.71 \\
25.71 \\
25.71 \\
25.98\end{array}$ & $\begin{array}{l}0.000 \\
0.001 \\
0.000 \\
0.001\end{array}$ & $\begin{array}{l}0.00 \\
0.01 \\
0.00 \\
.00\end{array}$ & $\begin{array}{l}0.16 \\
0.16 \\
0.16 \\
0.17 \\
0.17 \\
0.17 \\
0.17\end{array}$ \\
\hline
\end{tabular}




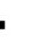

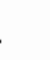

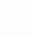

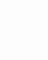

. 


\section{APPENDIX D}

CHEMICAL ANALYSES OF LEACHATES 


\section{CHEMICAL ANAYLYSES OF LEACHATES}

The first listing of data in this appendix is the complete chemical analyses of all quarterly samples taken at the lysimeter facility. Some lysimeters have more results than others depending on whether there was leachate collected on the particular sampling dates. The cations were analyzed with ICP and the anions with IC. All concentrations presented in the listing are milligrams per liter. Less than values represent limits of detection for the individual chemical species. The second data listing presents both drainage data and cumulative amounts of selected chemicals leached from each lysimeter. The data are similar to those presented for radionuclides in Appendix $C$. 
LYSIMETER 1

\begin{tabular}{|c|c|c|c|c|c|c|c|c|}
\hline & 240СТ84 & 20 JUN85 & 240СТ85 & 30JAN86 & 25APR86 & 24JUL86 & 6N0V86 & 9FEB87 \\
\hline $\begin{array}{ll}1 & \mathrm{pH} \\
2 & \mathrm{Eh} \\
4 & \mathrm{Al} \\
5 & \mathrm{~B} \\
6 & \mathrm{H} 3 \mathrm{B0} 3 \\
7 & \mathrm{Ba} \\
8 & \mathrm{Ca} \\
9 & \mathrm{Cd} \\
10 & \mathrm{Cr} \\
11 & \mathrm{Cu} \\
12 & \mathrm{Fe} \\
13 & \mathrm{~K} \\
14 & \mathrm{Li} \\
15 & \mathrm{Mg} \\
16 & \mathrm{Mn} \\
17 & \mathrm{Na} \\
18 \mathrm{Ni} \\
19 \mathrm{P} \\
20 \mathrm{Si} \\
21 \mathrm{Sr} \\
22 \mathrm{Zn} \\
23 \mathrm{~F}- \\
24 \mathrm{Cl}- \\
25 \mathrm{NO2}- \\
26 \mathrm{NO3-} \\
27 \mathrm{SO4}- \\
28 \mathrm{P04}- \\
29 \mathrm{ALKALINITY} \\
30 \mathrm{IC} \\
31 \mathrm{TOC} \\
32 \mathrm{CATIONS} \\
33 \mathrm{ANIONS}\end{array}$ & $\begin{array}{r}8.340 \\
312.000 \\
<0.030 \\
0.120 \\
0.685 \\
0.120 \\
54.700 \\
<0.004 \\
<0.020 \\
0.010 \\
<0.005 \\
46.000 \\
<0.004 \\
11.020 \\
0.150 \\
127.000 \\
<0.020 \\
0.200 \\
23.500 \\
0.320 \\
0.510 \\
9.200 \\
3.990 \\
<1.000 \\
0.300 \\
60.300 \\
0.613 \\
206.280 \\
104.600 \\
124.400 \\
10.340 \\
8.734\end{array}$ & $\begin{array}{r}8.270 \\
257.000 \\
<0.030 \\
<0.010 \\
<5.710 \\
0.230 \\
98.100 \\
<0.004 \\
0.020 \\
<0.004 \\
<0.005 \\
10.400 \\
<0.004 \\
22.200 \\
<0.002 \\
31.200 \\
<0.020 \\
<0.100 \\
14.100 \\
0.460 \\
0.150 \\
0.510 \\
6.600 \\
<1.000 \\
246.000 \\
66.000 \\
0.3065 \\
30.000 \\
\text { NA } \\
\text { NA } \\
8.355 \\
7.160\end{array}$ & $\begin{array}{r}8.240 \\
270.000 \\
<0.030 \\
0.056 \\
0.320 \\
0.268 \\
103.000 \\
<0.004 \\
0.043 \\
0.021 \\
<0.025 \\
16.000 \\
<0.073 \\
23.700 \\
0.005 \\
37.000 \\
<0.020 \\
0.100 \\
17.600 \\
0.511 \\
0.057 \\
0.700 \\
5.700 \\
<1.000 \\
296.000 \\
68.000 \\
0.306 \\
54.000 \\
30.750 \\
10.160 \\
9.119 \\
8.189\end{array}$ & $\begin{array}{r}8.160 \\
236.700 \\
<0.030 \\
0.042 \\
0.240 \\
0.150 \\
130.000 \\
0.007 \\
0.042 \\
0.009 \\
<0.025 \\
13.000 \\
0.084 \\
31.500 \\
0.003 \\
33.000 \\
<0.020 \\
0.200 \\
15.700 \\
0.578 \\
0.110 \\
0.700 \\
5.200 \\
<1.000 \\
435.000 \\
65.000 \\
0.306 \\
40.908 \\
22.910 \\
7.350 \\
10.860 \\
9.918\end{array}$ & $\begin{array}{r}8.290 \\
249.400 \\
<0.030 \\
0.117 \\
0.668 \\
0.060 \\
74.900 \\
<0.004 \\
<0.020 \\
0.005 \\
0.011 \\
7.300 \\
0.080 \\
18.500 \\
<0.002 \\
17.000 \\
<0.020 \\
<0.100 \\
18.800 \\
0.320 \\
0.100 \\
<1.000 \\
4.100 \\
<1.000 \\
32.000 \\
39.000 \\
<0.306 \\
\text { NA } \\
15.900 \\
7.200 \\
6.193 \\
\text { NA }\end{array}$ & $\begin{array}{r}8.230 \\
296.000 \\
<0.030 \\
0.200 \\
1.142 \\
0.060 \\
70.000 \\
<0.004 \\
<0.020 \\
<0.004 \\
<0.005 \\
<0.300 \\
<0.004 \\
16.000 \\
<0.002 \\
22.000 \\
<0.020 \\
<0.100 \\
20.000 \\
0.300 \\
<0.020 \\
<1.000 \\
3.600 \\
<1.000 \\
210.000 \\
38.000 \\
<0.306 \\
45.000 \\
20.120 \\
7.120 \\
5.773 \\
5.780\end{array}$ & $\begin{array}{r}8.520 \\
382.000 \\
<0.030 \\
0.188 \\
1.073 \\
0.098 \\
70.400 \\
<0.004 \\
<0.020 \\
0.020 \\
0.010 \\
29.000 \\
0.078 \\
15.900 \\
<0.002 \\
39.000 \\
<0.020 \\
<0.100 \\
17.700 \\
0.330 \\
0.094 \\
<1.000 \\
3.400 \\
<1.000 \\
190.000 \\
40.000 \\
<0.306 \\
\text { NA } \\
\text { NA } \\
\text { NA } \\
7.266 \\
\text { NA }\end{array}$ & $\begin{array}{r}8.620 \\
321.000 \\
<0.030 \\
0.140 \\
0.799 \\
0.110 \\
82.600 \\
<0.004 \\
<0.020 \\
0.018 \\
0.010 \\
35.400 \\
0.062 \\
19.100 \\
<0.002 \\
45.600 \\
<0.020 \\
<0.100 \\
14.400 \\
0.380 \\
0.060 \\
0.600 \\
4.300 \\
1.000 \\
240.000 \\
47.000 \\
<0.306 \\
96.600 \\
145.730 \\
11.770 \\
8.590 \\
8.245\end{array}$ \\
\hline
\end{tabular}


LYSIMETER 2

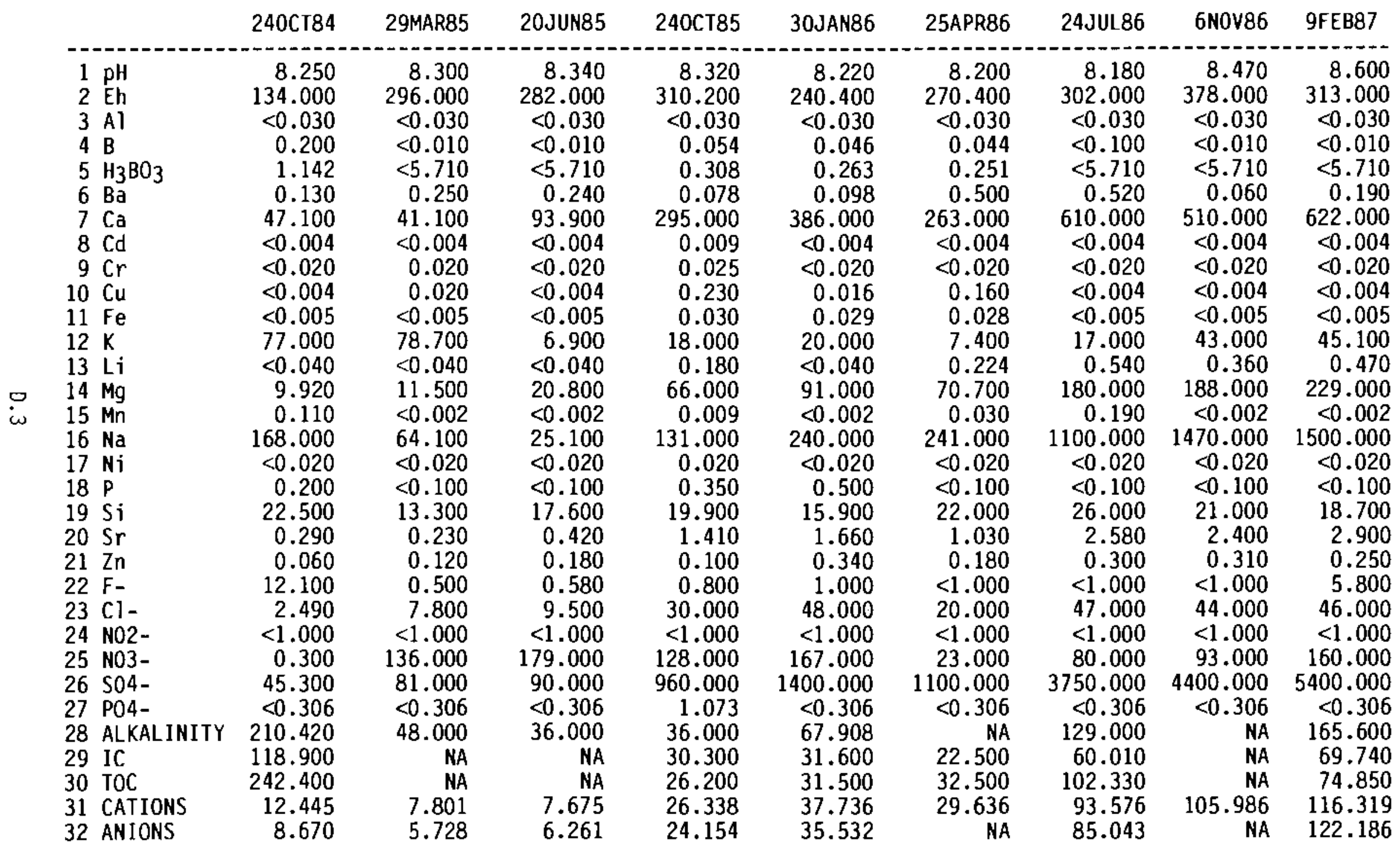


LYSIMETER 3

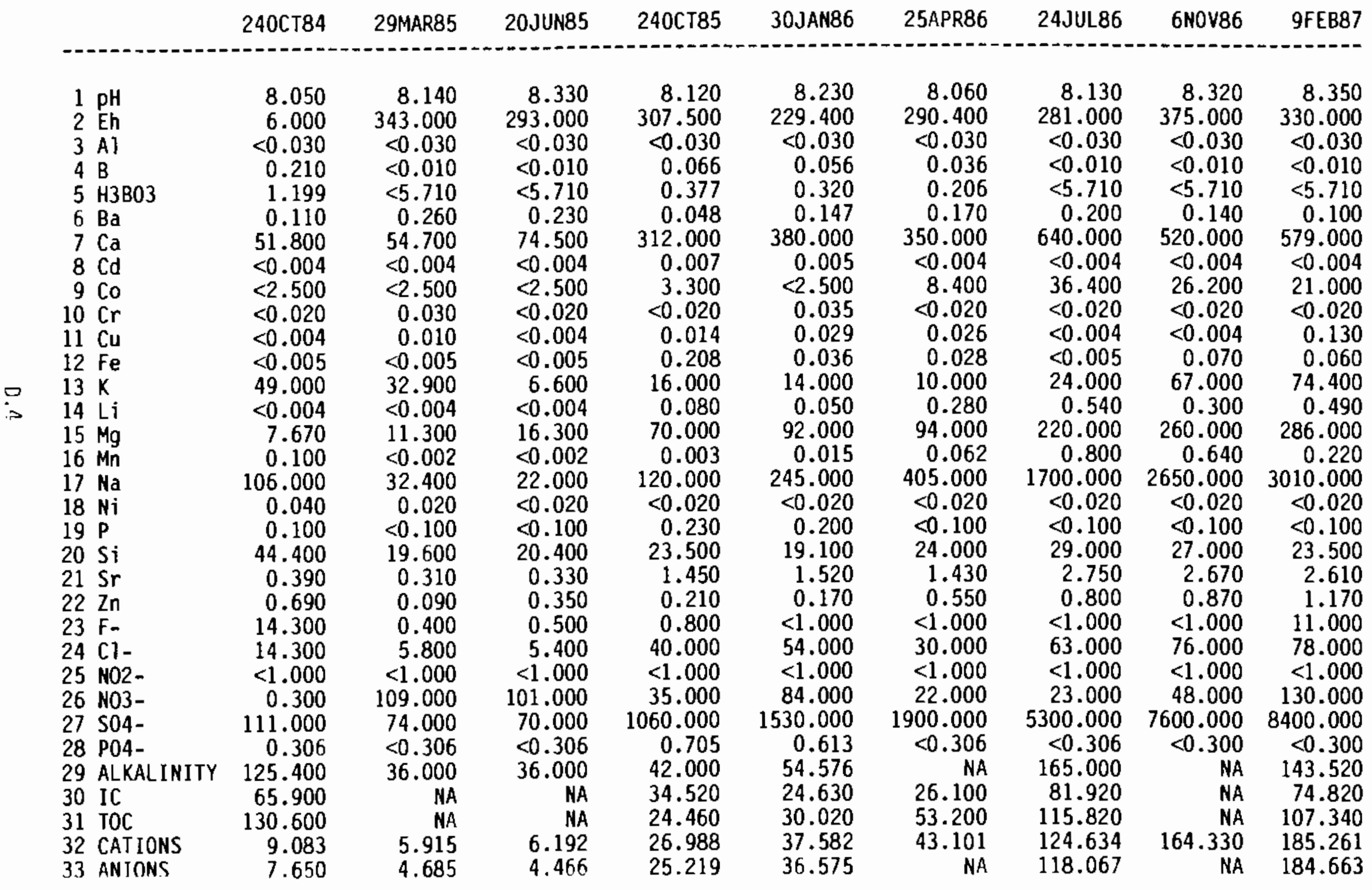


LYSIMETER 4

\begin{tabular}{|c|c|c|c|c|c|c|c|c|c|}
\hline & 240 СТ84 & 29MAR85 & 20 JUNB5 & 240 СT85 & 30JAN86 & 25APR86 & 24JUL86 & 6NOVB6 & 9FEB87 \\
\hline $\begin{array}{rl}1 & \mathrm{pH} \\
2 & \mathrm{Eh} \\
3 & \mathrm{Al} \\
4 & \mathrm{~B} \\
5 & \mathrm{H}_{3} \mathrm{B0}_{3} \\
6 & \mathrm{Ba} \\
7 & \mathrm{Ca} \\
8 & \mathrm{Cd} \\
9 & \mathrm{Cr} \\
10 & \mathrm{Cu} \\
11 & \mathrm{Fe} \\
12 & \mathrm{~K} \\
13 & \mathrm{Li} \\
14 & \mathrm{Mg} \\
15 & \mathrm{Mn} \\
16 & \mathrm{Na} \\
17 & \mathrm{Ni} \\
18 & \mathrm{P} \\
19 & \mathrm{Si} \\
20 & \mathrm{Sr} \\
21 & \mathrm{Zn} \\
22 & \mathrm{~F}- \\
23 & \mathrm{Cl}- \\
24 & \mathrm{NO2}- \\
25 & \mathrm{NO3-} \\
26 & \mathrm{SO4-} \\
27 & \mathrm{P04}- \\
28 & \mathrm{ALKALINITY} \\
29 & \mathrm{IC} \\
30 & \mathrm{TOC} \\
31 & \mathrm{CATIONS} \\
32 & \mathrm{ANIONS}\end{array}$ & $\begin{array}{r}8.120 \\
-17.000 \\
<0.030 \\
0.420 \\
2.398 \\
0.180 \\
62.000 \\
<0.004 \\
<0.020 \\
<0.004 \\
0.200 \\
173.000 \\
<0.004 \\
18.610 \\
0.220 \\
266.000 \\
<0.020 \\
0.200 \\
33.200 \\
0.420 \\
0.170 \\
25.400 \\
5.490 \\
<1.000 \\
0.300 \\
90.700 \\
0.613 \\
293.700 \\
163.700 \\
343.400 \\
20.621 \\
13.170\end{array}$ & $\begin{array}{r}8.260 \\
319.000 \\
<0.030 \\
<0.010 \\
<0.571 \\
0.350 \\
148.000 \\
<0.004 \\
0.010 \\
0.050 \\
<0.005 \\
286.000 \\
<0.004 \\
44.900 \\
<0.002 \\
105.000 \\
0.040 \\
<0.100 \\
13.300 \\
0.830 \\
0.300 \\
4.100 \\
72.000 \\
3.000 \\
108.000 \\
447.000 \\
<0.306 \\
72.000 \\
\text { NA } \\
\text { NA } \\
22.975 \\
8.710\end{array}$ & $\begin{array}{r}8.390 \\
293.000 \\
<0.030 \\
<0.010 \\
<0.571 \\
0.310 \\
190.000 \\
<0.004 \\
<0.020 \\
<0.004 \\
<0.005 \\
10.300 \\
<0.004 \\
42.800 \\
0.080 \\
34.000 \\
0.020 \\
<0.100 \\
14.000 \\
0.880 \\
1.820 \\
0.490 \\
49.000 \\
6.000 \\
104.000 \\
326.000 \\
<0.306 \\
60.000 \\
\mathrm{NA} \\
\mathrm{NA} \\
14.764 \\
7.380\end{array}$ & $\begin{array}{r}8.000 \\
314.100 \\
<0.030 \\
0.076 \\
0.434 \\
0.400 \\
271.000 \\
0.008 \\
0.020 \\
0.014 \\
0.048 \\
15.000 \\
0.090 \\
61.500 \\
0.046 \\
99.000 \\
0.020 \\
0.200 \\
17.700 \\
1.330 \\
0.310 \\
0.700 \\
65.000 \\
5.600 \\
52.000 \\
690.000 \\
0.613 \\
84.000 \\
\mathrm{NA} \\
\mathrm{NA} \\
23.300 \\
20.000\end{array}$ & $\begin{array}{r}8.150 \\
254.200 \\
<0.030 \\
0.123 \\
0.702 \\
0.180 \\
525.000 \\
0.009 \\
<0.020 \\
0.041 \\
0.069 \\
17.000 \\
0.060 \\
135.000 \\
0.017 \\
430.000 \\
0.150 \\
1.000 \\
14.000 \\
2.170 \\
0.070 \\
1.300 \\
65.000 \\
<1.000 \\
128.000 \\
2230.000 \\
3.065 \\
109.152 \\
\mathrm{NA} \\
\mathrm{NA} \\
56.492 \\
51.780\end{array}$ & $\begin{array}{r}8.060 \\
315.100 \\
<0.030 \\
0.100 \\
0.571 \\
0.140 \\
187.000 \\
<0.004 \\
<0.020 \\
0.014 \\
0.038 \\
10.000 \\
0.194 \\
45.000 \\
0.006 \\
261.000 \\
<0.020 \\
0.400 \\
17.000 \\
0.780 \\
0.600 \\
<1.000 \\
17.000 \\
<1.000 \\
14.000 \\
740.000 \\
1.226 \\
\mathrm{NA} \\
45.300 \\
195.000 \\
24.657 \\
\mathrm{NA}\end{array}$ & $\begin{array}{r}8.020 \\
311.000 \\
<0.030 \\
0.100 \\
0.571 \\
0.220 \\
320.000 \\
<0.004 \\
<0.020 \\
<0.004 \\
<0.005 \\
7.000 \\
0.250 \\
73.000 \\
<0.002 \\
290.000 \\
<0.020 \\
<0.100 \\
18.000 \\
1.350 \\
1.200 \\
<1.000 \\
24.000 \\
<1.000 \\
71.000 \\
1060.000 \\
<0.306 \\
171.000 \\
178.000 \\
304.200 \\
34.796 \\
29.600\end{array}$ & $\begin{array}{r}8.070 \\
387.000 \\
<0.030 \\
0.260 \\
1.485 \\
0.190 \\
585.000 \\
<0.004 \\
<0.020 \\
<0.004 \\
0.140 \\
52.000 \\
0.280 \\
174.000 \\
0.060 \\
1220.000 \\
0.200 \\
1.300 \\
15.000 \\
2.780 \\
2.330 \\
<1.000 \\
53.000 \\
<1.000 \\
54.000 \\
3900.000 \\
3.984 \\
\mathrm{NA} \\
\mathrm{NA} \\
\mathrm{NA} \\
97.944 \\
83.610\end{array}$ & $\begin{array}{r}8.130 \\
328.000 \\
<0.030 \\
0.240 \\
1.370 \\
0.380 \\
829.000 \\
<0.004 \\
<0.020 \\
<0.000 \\
0.120 \\
52.700 \\
0.530 \\
265.000 \\
<0.002 \\
1500.000 \\
0.210 \\
2.000 \\
13.400 \\
3.910 \\
3.200 \\
2.400 \\
69.000 \\
<1.000 \\
105.000 \\
5100.000 \\
6.130 \\
212.520 \\
508.140 \\
936.740 \\
129.826 \\
117.100\end{array}$ \\
\hline
\end{tabular}


LYSIMETER 5

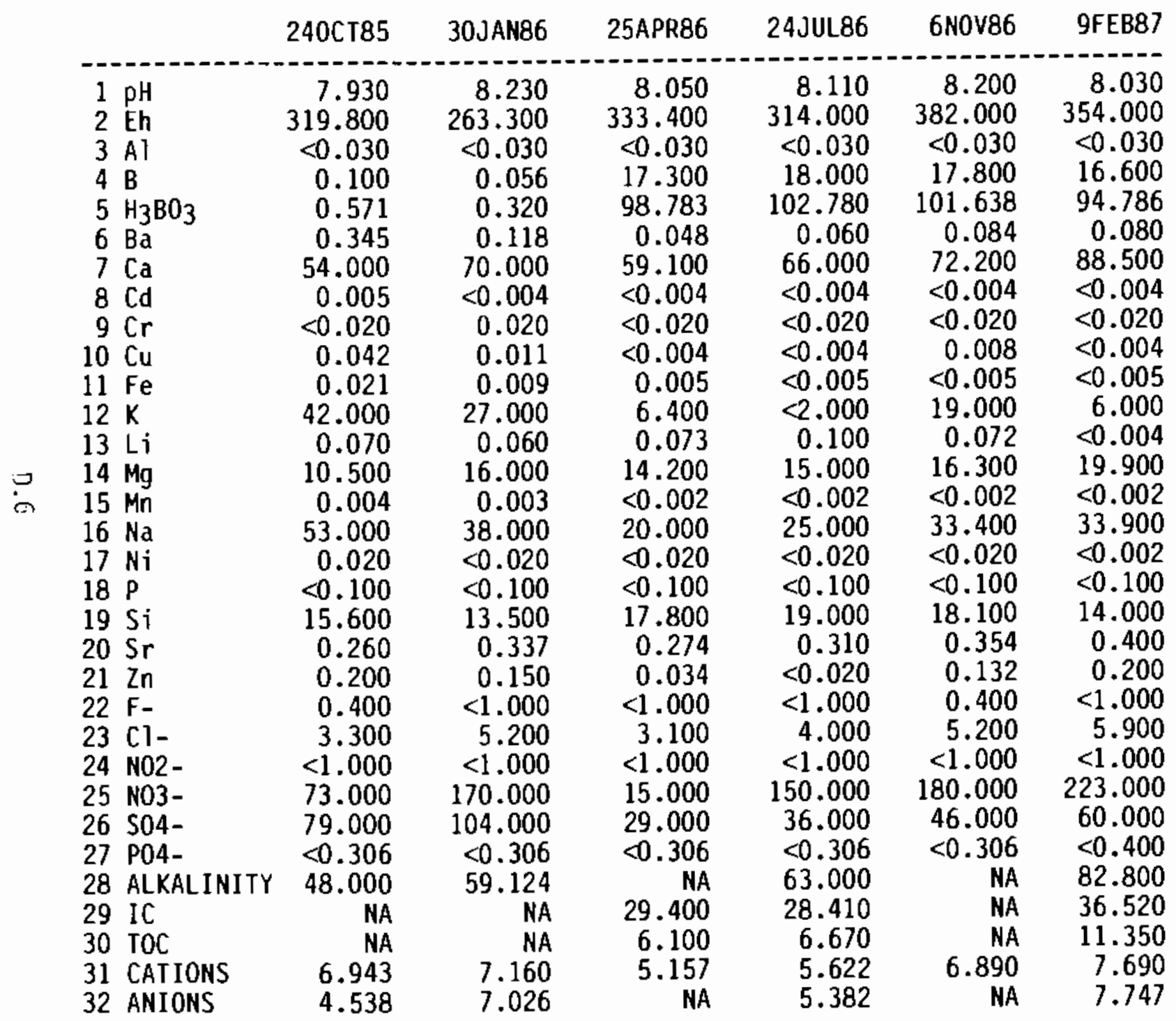


LYSIMETER 6

\begin{tabular}{|c|c|c|c|c|c|c|c|}
\hline & $240 \mathrm{CT} 84$ & $240 \mathrm{CT} 85$ & 30JAN86 & 25APR86 & 24JUL86 & 6NOV86 & $9 F E B 87$ \\
\hline $\begin{array}{ll}1 & \mathrm{pH} \\
2 & \mathrm{Eh} \\
3 & \mathrm{Al} \\
4 & \mathrm{~B} \\
5 & \mathrm{H}_{3} \mathrm{BO}_{3} \\
6 & \mathrm{Ba} \\
7 & \mathrm{Ca} \\
8 & \mathrm{Cd} \\
9 & \mathrm{Cr} \\
0 & \mathrm{Cu} \\
1 & \mathrm{Fe} \\
2 & \mathrm{~K} \\
3 & \mathrm{Li} \\
4 & \mathrm{Mg} \\
5 & \mathrm{Mn} \\
6 & \mathrm{Na} \\
7 & \mathrm{Ni} \\
8 & \mathrm{P} \\
9 & \mathrm{Si} \\
0 & \mathrm{Sr} \\
1 & \mathrm{Zn} \\
2 & \mathrm{~F}- \\
3 & \mathrm{Cl}- \\
4 & \mathrm{NO}- \\
5 & \mathrm{NO}- \\
6 & \mathrm{SO}- \\
7 & \mathrm{PO}- \\
8 & \mathrm{ALKALINITY} \\
9 & 1 \mathrm{C} \\
0 & \mathrm{TOC} \\
1 & \mathrm{CATIONS} \\
2 & \mathrm{ANIONS} \\
\end{array}$ & $\begin{array}{r}7.640 \\
259.000 \\
<0.030 \\
0.060 \\
0.342 \\
0.124 \\
90.000 \\
<0.004 \\
<0.020 \\
0.010 \\
<0.005 \\
54.000 \\
<0.004 \\
20.720 \\
0.020 \\
71.400 \\
<0.020 \\
0.200 \\
20.000 \\
0.520 \\
0.870 \\
0.500 \\
5.180 \\
27.100 \\
52.300 \\
69.000 \\
0.613 \\
178.200 \\
81.200 \\
14.700 \\
10.690 \\
9.931\end{array}$ & $\begin{array}{r}8.210 \\
338.700 \\
<0.030 \\
0.082 \\
0.468 \\
0.279 \\
83.000 \\
<0.004 \\
<0.020 \\
0.018 \\
0.019 \\
29.000 \\
0.084 \\
21.000 \\
0.005 \\
40.000 \\
<0.020 \\
0.200 \\
14.900 \\
0.459 \\
0.230 \\
0.400 \\
4.400 \\
<1.000 \\
118.000 \\
56.000 \\
0.613 \\
66.000 \\
\text { NA } \\
\text { NA } \\
8.359 \\
5.415\end{array}$ & $\begin{array}{r}8.100 \\
272.300 \\
<0.030 \\
0.064 \\
0.365 \\
0.124 \\
83.000 \\
<0.004 \\
0.020 \\
0.009 \\
0.056 \\
16.000 \\
0.056 \\
20.000 \\
0.008 \\
34.000 \\
0.020 \\
<0.100 \\
13.900 \\
0.428 \\
0.220 \\
0.700 \\
4.800 \\
1.200 \\
158.000 \\
61.000 \\
<0.306 \\
86.412 \\
\mathrm{NA} \\
\mathrm{NA} \\
7.684 \\
6.898\end{array}$ & $\begin{array}{r}8.040 \\
332.400 \\
<0.030 \\
24.500 \\
139.895 \\
0.059 \\
74.200 \\
<0.004 \\
<0.020 \\
0.029 \\
0.041 \\
5.100 \\
0.080 \\
18.200 \\
<0.002 \\
19.000 \\
<0.020 \\
<0.100 \\
18.800 \\
0.320 \\
0.160 \\
<1.000 \\
5.200 \\
<1.000 \\
25.000 \\
34.000 \\
<0.306 \\
\text { NA } \\
25.000 \\
6.400 \\
6.164 \\
\mathrm{NA}\end{array}$ & $\begin{array}{r}8.020 \\
319.000 \\
<0.030 \\
36.000 \\
205.560 \\
0.070 \\
85.000 \\
<0.004 \\
<0.020 \\
<0.004 \\
0.100 \\
<2.000 \\
0.060 \\
20.000 \\
<0.002 \\
24.000 \\
<0.020 \\
<0.100 \\
21.000 \\
0.380 \\
<0.020 \\
<1.000 \\
5.300 \\
<1.000 \\
190.000 \\
39.000 \\
<0.306 \\
81.000 \\
32.820 \\
8.300 \\
6.939 \\
6.727\end{array}$ & $\begin{array}{r}8.180 \\
386.000 \\
<0.030 \\
32.200 \\
183.862 \\
0.100 \\
83.800 \\
<0.004 \\
<0.020 \\
0.010 \\
0.012 \\
17.000 \\
0.072 \\
20.200 \\
<0.002 \\
30.400 \\
<0.020 \\
<0.100 \\
19.300 \\
0.392 \\
0.106 \\
0.400 \\
5.600 \\
<1.000 \\
210.000 \\
42.000 \\
<0.306 \\
\text { NA } \\
\text { NA } \\
\text { NA } \\
7.609 \\
\text { NA }\end{array}$ & $\begin{array}{r}8.260 \\
341.000 \\
<0.030 \\
16.000 \\
91.360 \\
0.120 \\
97.200 \\
<0.004 \\
<0.020 \\
0.016 \\
0.014 \\
25.600 \\
0.086 \\
23.000 \\
0.004 \\
35.400 \\
<0.020 \\
<0.100 \\
14.600 \\
0.440 \\
0.100 \\
<1.000 \\
5.500 \\
<1.000 \\
360.000 \\
60.000 \\
<0.306 \\
113.160 \\
37.970 \\
9.330 \\
8.947 \\
10.984\end{array}$ \\
\hline
\end{tabular}


LYSIMETER 7

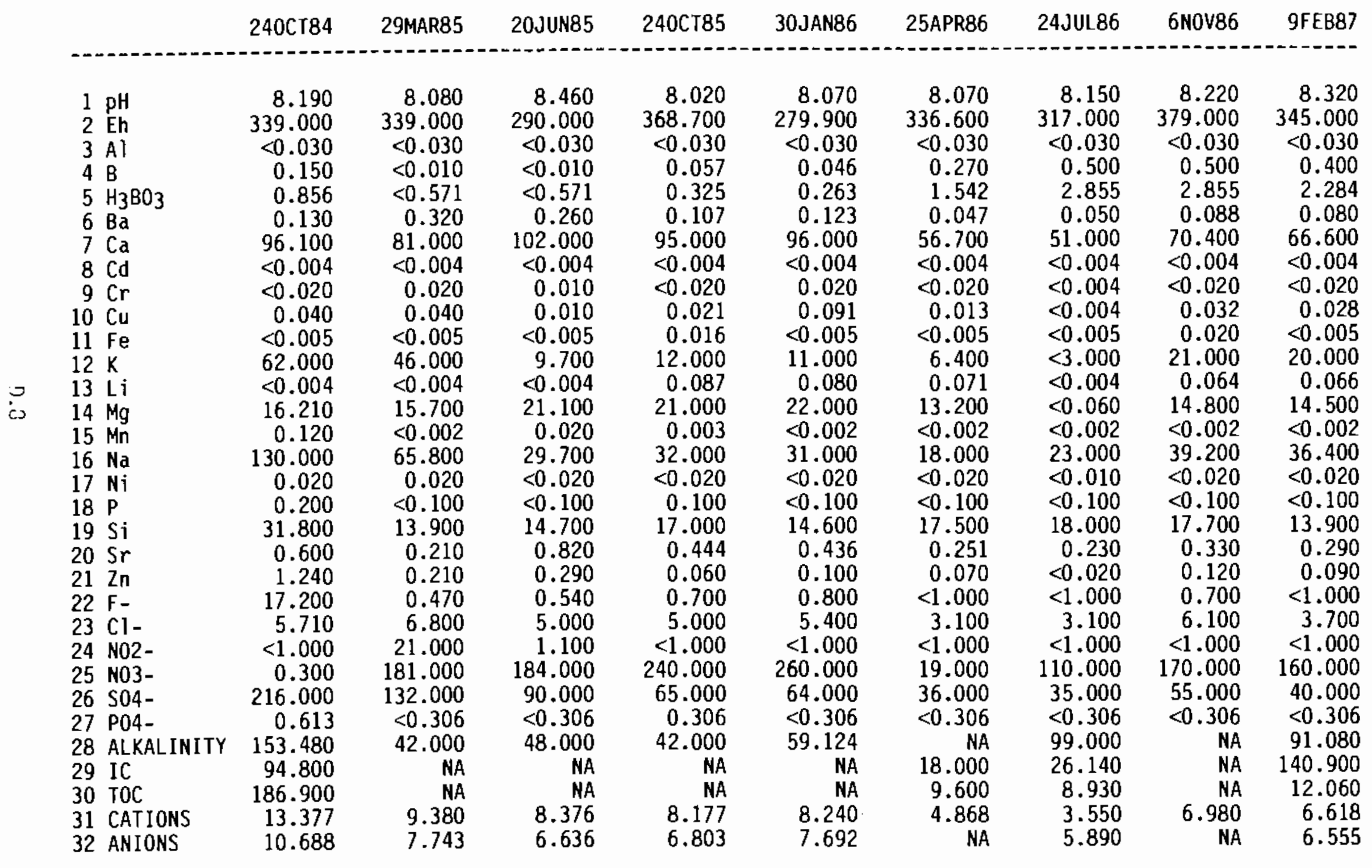


LYSIMETER 8

\begin{tabular}{|c|c|c|c|c|c|c|c|c|c|}
\hline & $240 \mathrm{CT} 84$ & 29MAR85 & 20 JUN85 & 240 CT85 & 30JAN86 & 25APR86 & 24JUL86 & 6N0V86 & 9FEB87 \\
\hline $\begin{array}{ll}1 & \mathrm{pH} \\
2 & \mathrm{Eh} \\
3 & \mathrm{Al} \\
4 & \mathrm{~B} \\
5 & \mathrm{H} 3 \mathrm{B0}_{3} \\
6 & \mathrm{Ba} \\
7 & \mathrm{Ca} \\
8 & \mathrm{Cd} \\
9 & \mathrm{Cr} \\
10 & \mathrm{Cu} \\
11 & \mathrm{Fe} \\
12 & \mathrm{~K} \\
13 & \mathrm{Li} \\
14 & \mathrm{Mg} \\
15 & \mathrm{Mn} \\
16 & \mathrm{Na} \\
17 & \mathrm{Ni} \\
18 & \mathrm{P} \\
19 & \mathrm{Si} \\
20 & \mathrm{Sr} \\
21 & \mathrm{Zn} \\
22 & \mathrm{~F}- \\
23 & \mathrm{Cl}- \\
24 & \mathrm{NO2}- \\
25 & \mathrm{NO3-} \\
26 & \mathrm{SO4-} \\
27 & \mathrm{PO4-} \\
28 & \mathrm{ALKALINITY} \\
29 & \mathrm{IC} \\
30 & \mathrm{TOC} \\
31 & \mathrm{CATIONS} \\
32 & \mathrm{ANIONS}\end{array}$ & $\begin{array}{r}7.730 \\
288.000 \\
<0.030 \\
0.180 \\
1.028 \\
0.130 \\
76.000 \\
<0.004 \\
0.020 \\
0.020 \\
<0.005 \\
88.000 \\
<0.004 \\
16.040 \\
0.070 \\
153.000 \\
0.020 \\
0.200 \\
37.900 \\
0.560 \\
1.150 \\
13.100 \\
3.730 \\
<1.000 \\
0.200 \\
181.000 \\
0.613 \\
199.680 \\
102.300 \\
181.900 \\
14.023 \\
10.375\end{array}$ & $\begin{array}{r}7.780 \\
322.000 \\
<0.030 \\
<0.010 \\
<0.571 \\
0.250 \\
91.800 \\
<0.004 \\
0.030 \\
0.020 \\
<0.005 \\
5.200 \\
<0.004 \\
21.400 \\
<0.002 \\
21.800 \\
0.010 \\
0.300 \\
18.500 \\
0.340 \\
0.280 \\
0.620 \\
7.500 \\
<1.000 \\
88.000 \\
195.000 \\
0.919 \\
24.000 \\
\mathrm{NA} \\
\mathrm{NA} \\
7.432 \\
6.526\end{array}$ & $\begin{array}{r}8.370 \\
290.000 \\
<0.030 \\
<0.010 \\
<0.571 \\
0.260 \\
94.100 \\
<0.004 \\
<0.020 \\
0.010 \\
<0.005 \\
7.400 \\
<0.004 \\
21.100 \\
<0.002 \\
21.300 \\
<0.020 \\
<0.100 \\
19.800 \\
0.400 \\
0.820 \\
0.500 \\
57.000 \\
1.500 \\
57.000 \\
187.000 \\
<0.306 \\
30.000 \\
\mathrm{NA} \\
\mathrm{NA} \\
7.557 \\
7.484\end{array}$ & $\begin{array}{r}8.190 \\
353.400 \\
<0.030 \\
0.065 \\
0.371 \\
0.214 \\
256.000 \\
<0.004 \\
<0.020 \\
0.017 \\
0.064 \\
18.000 \\
0.190 \\
61.000 \\
0.128 \\
113.000 \\
0.020 \\
0.200 \\
23.300 \\
1.210 \\
0.230 \\
0.800 \\
32.000 \\
<1.000 \\
9.000 \\
955.000 \\
0.613 \\
42.000 \\
\mathrm{NA} \\
\mathrm{NA} \\
23.194 \\
22.388\end{array}$ & $\begin{array}{r}8.210 \\
269.600 \\
<0.030 \\
0.049 \\
0.280 \\
0.137 \\
331.000 \\
0.006 \\
0.035 \\
0.045 \\
0.035 \\
17.000 \\
0.050 \\
81.000 \\
0.012 \\
193.000 \\
0.110 \\
0.400 \\
14.600 \\
1.370 \\
0.167 \\
0.700 \\
46.000 \\
<1.000 \\
49.000 \\
1300.000 \\
1.226 \\
63.672 \\
N A \\
N A \\
32.043 \\
31.332\end{array}$ & $\begin{array}{r}8.000 \\
365.700 \\
<0.030 \\
0.038 \\
0.217 \\
0.180 \\
252.000 \\
<0.004 \\
<0.020 \\
0.046 \\
0.020 \\
7.400 \\
0.212 \\
72.000 \\
0.058 \\
207.000 \\
0.046 \\
<0.100 \\
23.000 \\
1.000 \\
0.240 \\
<1.000 \\
18.000 \\
<1.000 \\
14.000 \\
1100.000 \\
<0.306 \\
\text { NA } \\
26.000 \\
33.300 \\
27.715 \\
\text { NA }\end{array}$ & $\begin{array}{r}8.130 \\
296.000 \\
<0.030 \\
<0.010 \\
<0.571 \\
0.410 \\
48.000 \\
<0.004 \\
<0.020 \\
0.050 \\
0.080 \\
24.000 \\
0.430 \\
210.000 \\
0.990 \\
1700.000 \\
<0.020 \\
1.000 \\
30.000 \\
2.150 \\
0.400 \\
<1.000 \\
52.000 \\
<1.000 \\
<2.000 \\
5100.000 \\
3.065 \\
225.000 \\
100.760 \\
139.350 \\
94.211 \\
115.219\end{array}$ & $\begin{array}{r}8.460 \\
389.000 \\
<0.030 \\
<0.010 \\
<0.571 \\
0.060 \\
424.000 \\
<0.004 \\
<0.020 \\
0.130 \\
0.240 \\
56.000 \\
0.260 \\
198.000 \\
0.020 \\
2100.000 \\
<0.020 \\
<0.100 \\
25.600 \\
1.960 \\
0.220 \\
<1.000 \\
49.000 \\
<1.000 \\
69.000 \\
5600.000 \\
<0.306 \\
\mathrm{NA} \\
\mathrm{NA} \\
\mathrm{NA} \\
130.233 \\
\mathrm{NA}\end{array}$ & $\begin{array}{r}8.520 \\
341.000 \\
<0.030 \\
<0.010 \\
<0.571 \\
0.210 \\
513.000 \\
<0.004 \\
<0.020 \\
0.120 \\
<0.005 \\
54.000 \\
0.290 \\
227.000 \\
<0.002 \\
2050.000 \\
<0.020 \\
<0.100 \\
23.200 \\
2.260 \\
<0.020 \\
7.100 \\
47.000 \\
<1.000 \\
126.000 \\
5800.000 \\
<0.306 \\
173.880 \\
74.880 \\
82.500 \\
134.845 \\
130.360\end{array}$ \\
\hline
\end{tabular}


LYSIMETER 9

\begin{tabular}{|c|c|c|c|c|c|c|c|c|c|}
\hline & 240 СТ84 & 29MAR85 & 20JUN85 & 240 CT85 & 30JANB6 & 25APR86 & 24JUL86 & 6N0V86 & 9FEB87 \\
\hline $\begin{array}{ll}1 & \mathrm{pH} \\
2 & \mathrm{Eh} \\
3 & \mathrm{Al} \\
4 & \mathrm{~B} \\
5 & \mathrm{H} 3 \mathrm{BO} 3 \\
6 & \mathrm{Ba} \\
7 & \mathrm{Ca} \\
8 & \mathrm{Cd} \\
9 & \mathrm{Cr} \\
10 & \mathrm{Cu} \\
11 & \mathrm{Fe} \\
12 & \mathrm{~K} \\
13 & \mathrm{Li} \\
14 & \mathrm{Mg} \\
15 & \mathrm{Mn} \\
16 & \mathrm{Na} \\
17 & \mathrm{Ni} \\
18 & \mathrm{P} \\
19 & \mathrm{Si} \\
20 & \mathrm{Sr} \\
21 & \mathrm{Zn} \\
22 & \mathrm{~F}- \\
23 & \mathrm{Cl}- \\
24 & \mathrm{NO2}- \\
25 & \mathrm{~N} 03- \\
26 & \mathrm{SO4}- \\
27 & \mathrm{PO4}- \\
28 & \mathrm{ALKALINITY} \\
29 & \mathrm{IC} \\
30 & \mathrm{TOC} \\
31 & \mathrm{CATIONS} \\
32 & \mathrm{ANIONS}\end{array}$ & $\begin{array}{r}7.930 \\
376.000 \\
<0.030 \\
0.110 \\
0.628 \\
0.120 \\
141.500 \\
<0.004 \\
<0.020 \\
1.000 \\
<0.005 \\
87.000 \\
<0.004 \\
19.620 \\
0.140 \\
110.000 \\
0.030 \\
0.100 \\
22.300 \\
0.710 \\
1.030 \\
24.500 \\
6.900 \\
<1.000 \\
0.300 \\
261.000 \\
0.306 \\
123.780 \\
99.000 \\
212.000 \\
15.697 \\
11.053\end{array}$ & $\begin{array}{r}8.010 \\
352.000 \\
<0.030 \\
<0.010 \\
<0.571 \\
0.240 \\
70.100 \\
<0.004 \\
0.020 \\
0.170 \\
<0.005 \\
6.500 \\
<0.004 \\
16.400 \\
<0.002 \\
17.800 \\
0.010 \\
<0.100 \\
20.500 \\
0.300 \\
0.220 \\
0.650 \\
8.000 \\
<1.000 \\
112.000 \\
95.000 \\
<0.306 \\
24.000 \\
\text { NA } \\
\text { NA } \\
5.795 \\
4.846\end{array}$ & $\begin{array}{r}8.320 \\
299.000 \\
<0.030 \\
<0.010 \\
<0.571 \\
0.260 \\
92.100 \\
<0.004 \\
<0.020 \\
0.040 \\
<0.005 \\
8.200 \\
<0.004 \\
20.300 \\
<0.002 \\
21.900 \\
<0.020 \\
<0.100 \\
19.800 \\
0.400 \\
1.610 \\
0.690 \\
9.000 \\
2.400 \\
71.000 \\
171.000 \\
<0.306 \\
42.000 \\
\mathrm{NA} \\
\mathrm{NA} \\
7.438 \\
6.450\end{array}$ & $\begin{array}{r}8.220 \\
336.000 \\
<0.030 \\
0.067 \\
0.383 \\
0.156 \\
245.000 \\
0.008 \\
0.025 \\
0.070 \\
0.033 \\
22.000 \\
0.200 \\
57.000 \\
0.116 \\
196.000 \\
0.026 \\
1.100 \\
26.000 \\
1.190 \\
0.470 \\
0.700 \\
50.000 \\
<1.000 \\
50.000 \\
915.000 \\
3.371 \\
54.000 \\
\text { NA } \\
\text { NA } \\
26.026 \\
23.118\end{array}$ & $\begin{array}{r}8.360 \\
266.700 \\
<0.030 \\
0.043 \\
0.246 \\
0.129 \\
370.000 \\
0.006 \\
0.044 \\
0.170 \\
0.038 \\
26.000 \\
0.120 \\
88.000 \\
0.034 \\
253.000 \\
0.140 \\
1.600 \\
24.300 \\
1.660 \\
0.122 \\
<1.000 \\
81.000 \\
<1.000 \\
123.000 \\
1360.000 \\
4.904 \\
81.864 \\
\mathrm{NA} \\
\mathrm{NA} \\
37.408 \\
35.334\end{array}$ & $\begin{array}{r}8.260 \\
281.800 \\
<0.030 \\
0.042 \\
0.240 \\
0.220 \\
272.000 \\
<0.004 \\
<0.020 \\
0.070 \\
0.042 \\
15.000 \\
0.440 \\
96.500 \\
0.510 \\
486.000 \\
0.040 \\
2.000 \\
30.000 \\
1.250 \\
0.200 \\
<1.000 \\
23.000 \\
<1.000 \\
11.000 \\
1800.000 \\
6.130 \\
\mathrm{NA} \\
45.900 \\
74.200 \\
43.056 \\
\mathrm{NA}\end{array}$ & $\begin{array}{r}8.430 \\
271.000 \\
<0.030 \\
<0.010 \\
<0.571 \\
0.260 \\
34.000 \\
<0.004 \\
<0.020 \\
0.140 \\
<0.005 \\
52.000 \\
0.330 \\
200.000 \\
0.320 \\
2600.000 \\
<0.020 \\
7.000 \\
42.000 \\
1.860 \\
0.200 \\
<1.000 \\
59.000 \\
<1.000 \\
<2.000 \\
6000.000 \\
21.455 \\
333.000 \\
151.130 \\
255.230 \\
132.534 \\
137.767\end{array}$ & $\begin{array}{r}8.480 \\
401.000 \\
<0.030 \\
<0.010 \\
<0.571 \\
0.210 \\
445.000 \\
<0.004 \\
<0.020 \\
0.210 \\
<0.005 \\
58.000 \\
0.300 \\
188.000 \\
0.140 \\
2290.000 \\
<0.020 \\
1.400 \\
34.900 \\
2.090 \\
<0.020 \\
<1.000 \\
58.000 \\
<1.000 \\
78.000 \\
5600.000 \\
4.291 \\
\mathrm{NA} \\
\mathrm{NA} \\
\mathrm{NA} \\
138.772 \\
\mathrm{NA}\end{array}$ & $\begin{array}{r}8.500 \\
334.000 \\
<0.030 \\
<0.010 \\
<0.571 \\
0.180 \\
511.000 \\
<0.004 \\
<0.020 \\
0.270 \\
<0.005 \\
65.000 \\
0.390 \\
237.000 \\
0.080 \\
2530.000 \\
<0.020 \\
<0.100 \\
33.100 \\
2.350 \\
<0.020 \\
8.900 \\
65.000 \\
<1.000 \\
160.000 \\
7200.000 \\
<0.306 \\
212.520 \\
86.400 \\
118.260 \\
156.719 \\
161.969\end{array}$ \\
\hline
\end{tabular}


LYSIMETER 10

29MAR85 240CT85 30JAN86 25APR86 24JUL86 6NOV86

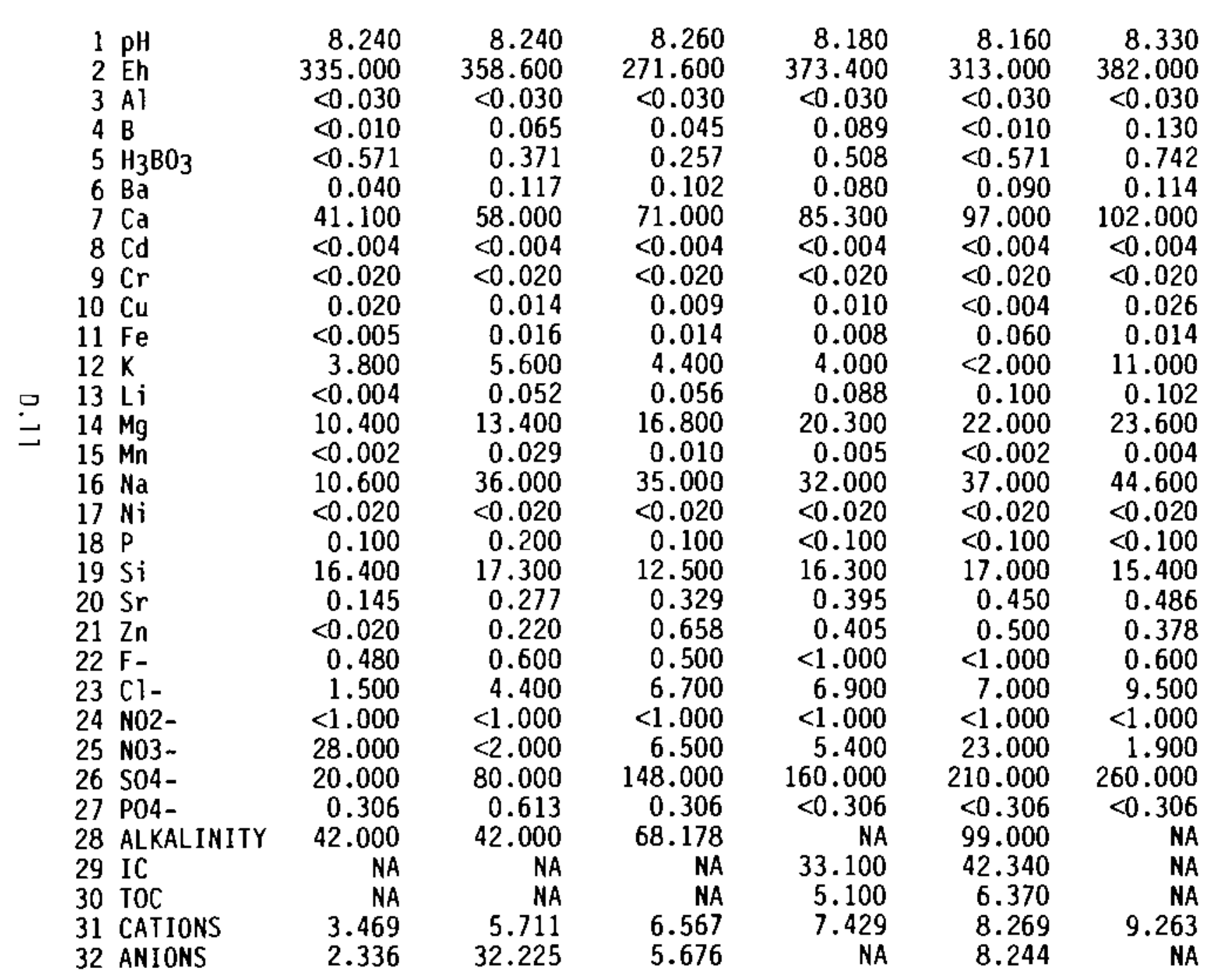


Lysimeter \#1 field chemistry

Masonry Cement

Boric Acid Concentrate

Drum 4-1

CLUATIIVE LEACHED, 9

CUTN

\begin{tabular}{|c|c|c|c|c|c|c|c|c|c|c|c|c|c|c|}
\hline DATE & DAY & $\begin{array}{l}\text { DRAIN } \\
\text { liters }\end{array}$ & $\begin{array}{c}\text { DRAIK } \\
\text { c }\end{array}$ & TOC & Ca+o & $\| \mathbf{g}+4$ & Sr. & $\mathrm{Na}$. & k. & B & $\mathrm{Cl}-$ & N03- & SO4-- & $\mathrm{Si}$ \\
\hline$-26-84$ & 300 & 1.10 & 0.04 & 0.137 & ต. 660 & 0.012 & .080 & 0.146 & c.051 & .000 & 0.004 & .860 & 6. 468 & 0.026 \\
\hline $1-16-84$ & 321 & 9.17 & 6.65 & 9.148 & 0.073 & 0.015 & .000 & D.153 & 0.055 & .800 & 0.005 & 0.021 & 0.077 & 6.829 \\
\hline $1-24-85$ & 390 & & 0.85 & 0.148 & 0.073 & 0.015 & .000 & 0.153 & 0.855 & .00 & อ. 005 & 0.021 & B. .077 & 1029 \\
\hline $2-13-85$ & 410 & 0.00 & 0.05 & a. 148 & 6.073 & 6. .15 & .680 & 0.153 & 0.655 & .600 & 0.685 & ๑. 821 & 6. .77 & 0.029 \\
\hline $3-11-85$ & 436 & & 0.05 & 0.148 & 0.673 & 016 & .080 & 0.153 & 8.955 & .860 & 0.005 & 0.621 & 0.077 & 0.029 \\
\hline $3-12-85$ & 437 & & 0.65 & 0.148 & 0.073 & 0.015 & .000 & 0.153 & 0.455 & .060 & 0.605 & 6.621 & 6.677 & c. 029 \\
\hline $3-29-85$ & 454 & 0.00 & 6. 65 & อ. 148 & 0.073 & 0.815 & .068 & 0.153 & 0.655 & .090 & อ.e95 & 0.821 & 0.077 & 0.629 \\
\hline $4-84-85$ & 468 & & c. 45 & 0.148 & 0.073 & 0.015 & .000 & 0.153 & 0.055 & .000 & 9.065 & 6.021 & 0.077 & 0.029 \\
\hline $4-12-85$ & 488 & & 0.05 & 0.148 & 0.073 & 0.615 & .000 & 0.153 & ๑.655 & .060 & 0.005 & 0.021 & 1.977 & t.829 \\
\hline $6-20-85$ & 537 & 60.20 & 1.98 & 3. 528 & 4.998 & 1.128 & 0.024 & 1.719 & 0.577 & 0.012 & 0. 337 & 12.376 & $3.39 \pi$ & 0.737 \\
\hline $7-23-85$ & 578 & & 1.96 & 3.528 & 4.898 & 1.128 & 0.624 & 1.719 & 0.577 & 0.012 & 0. 337 & 12.370 & 3. 396 & ต. 737 \\
\hline $8-14-85$ & 592 & 27.70 & 3.81 & 5.389 & 7.783 & 1.765 & 9.837 & 2.864 & 0.943 & 0.619 & 0.587 & 18.877 & 5.246 & 1.176 \\
\hline $0-24-85$ & 883 & 24.26 & 3.93 & 5.635 & 19.278 & 2.339 & 0.049 & 3.559 & 1.330 & 0.025 & 9. 645 & 27.040 & 8. 892 & 1.602 \\
\hline $1-39-88$ & 761 & 28.50 & 5.01 & 5.845 & 13.981 & 3. 238 & - . .086 & 4.500 & 1.761 & 0.829 & 0.793 & 39.438 & 8.744 & 2.049 \\
\hline $2-22-88$ & 784 & & 5.11 & 5.845 & 13.961 & 3. 236 & 6.068 & 4.560 & 1.781 & 0.029 & 0.793 & 38.438 & 8.744 & 2.049 \\
\hline $2-28-86$ & 790 & 50.80 & B. 95 & 8.214 & 19.185 & 4.506 & 0.088 & 6.770 & 2.218 & 6.035 & 1.629 & 51.300 & 11.386 & 2.926 \\
\hline $3-87-86$ & 797 & & 8. 95 & 8.214 & 19.185 & 4.580 & 0.089 & 5.776 & 2.216 & 0.035 & 1.029 & 51.300 & 11.386 & 2.926 \\
\hline $3-13-68$ & 893 & & 8.95 & 6.214 & 19.185 & 4.668 & ๑.689 & 5.779 & 2.216 & 4.036 & 1.029 & 51.300 & 11.386 & 2.826 \\
\hline $3-21-88$ & 011 & 58.60 & 9.15 & 6.836 & 25.127 & 5.958 & 6.116 & 7.220 & 2.865 & 0.041 & 1.299 & 84.843 & 14.462 & 3.928 \\
\hline $3-28-86$ & 818 & 14.60 & 9.68 & B. $73 B$ & 28.581 & B. 380 & 0.121 & 7.570 & 2.947 & 0.042 & 1.384 & 88.112 & 15.130 & 4.188 \\
\hline $4-63-88$ & 824 & 9.00 & 10.62 & 6.894 & 27.484 & 8.531 & g.125 & 7.795 & 3.639 & 0.043 & 1.408 & 70.213 & 15.598 & 4.323 \\
\hline $4-10-86$ & 831 & 13.00 & 16.52 & 8.898 & 28.815 & 6.858 & ๑. 131 & B.120 & 3.171 & 0.045 & 1.466 & 73.249 & 16.274 & 4.547 \\
\hline $4-17-88$ & $83 B$ & 9.00 & 16.86 & 6.984 & 29.737 & 7.061 & 0.135 & 6.345 & 3.262 & 0.046 & 1.580 & 75.350 & 18.742 & 4.702 \\
\hline $4-25-88$ & 848 & 9.70 & 11.23 & 7.033 & 36.464 & 7. 281 & 6.138 & 8.610 & 3. 333 & 0.046 & 1.548 & 75.661 & 17.120 & 4.885 \\
\hline $5-61-68$ & 852 & $7.5 \mathrm{~A}$ & 11.52 & 7.087 & 31.007 & 7.390 & 0.139 & 8.656 & 3.368 & 0.047 & 1.577 & 76.568 & 17.469 & 5.030 \\
\hline $5-68-88$ & 859 & 9.50 & 11.88 & 7.155 & 31.696 & 7.554 & 0.141 & 8.841 & 3.412 & 0.847 & 1.613 & 77.718 & 17.775 & 5.214 \\
\hline $5-15-88$ & 888 & 9.80 & 12.25 & 7. 225 & 32.408 & 7.723 & 0.143 & 9.032 & 3.457 & 0.048 & 1.651 & 78.983 & 18.152 & 5.165 \\
\hline $5-22-86$ & 873 & 7.40 & 12.53 & 7.278 & 32.942 & 7.851 & 0.144 & 9.177 & 3.492 & 0.048 & 1.680 & 79.799 & 18.437 & 5.548 \\
\hline
\end{tabular}


Lysimeter \#1 field chemistry (continued)

Masonry Cement

Boric Acid Concentrate

Drum 4-1

\begin{tabular}{|c|c|c|c|c|c|c|c|c|c|c|c|c|c|c|}
\hline & & & & & & cund & IVE LE & $H E D, g$ & & & & & & \\
\hline & & & CHIV & & & & & & & & & & & \\
\hline DATE & DAY & DRAIN & DRAIN & TOC & $\mathrm{Ca}_{2++}$ & $\mathrm{Hg}+4$ & $\mathrm{Sr}+$ & $\mathrm{Na} \cdot$ & $k$. & B & $\mathrm{Cl}-$ & NO3- & SO4.- & Si \\
\hline $5-29-88$ & 880 & 8.00 & 12.83 & 7.338 & 33.621 & 7.989 & 0.145 & 9.333 & 3.529 & 0.649 & 1.711 & 86.767 & 18.745 & 5.703 \\
\hline $6-86-86$ & 888 & 9.40 & 13.18 & 7.463 & 34.262 & 8.151 & 0.147 & 9.516 & 3.573 & 0.049 & 1.747 & 81.964 & 19.197 & 5.888 \\
\hline $6-69-86$ & 891 & & 13.19 & 7.403 & 34.292 & g. 151 & 0.147 & 9.516 & 3.573 & 0.049 & 1.747 & 81.964 & 19.107 & 5,886 \\
\hline $6-12-88$ & 894 & 5.88 & 13,40 & 7.443 & 94.698 & B. 248 & 0.148 & 9.825 & 3.599 & 0.056 & 1.768 & 82.582 & 19.322 & 5.994 \\
\hline $6-19-86$ & 961 & 6.70 & 13.86 & 7.491 & 35.004 & 8.363 & 0.149 & 9.758 & 3.639 & 0.050 & 1.794 & 83.392 & 19.580 & 6.124 \\
\hline 6-26-86 & 988 & 8.90 & 13.92 & 7.540 & 36.693 & 8.482 & e.158 & 9.890 & 3.882 & 0.050 & 1.821 & 84.227 & 19.848 & 6.258 \\
\hline $7-63-88$ & 215 & 7.60 & 14.19 & 7.591 & 36.101 & 8.803 & 0.152 & 10.627 & 3.694 & 0.051 & 1.848 & 85.674 & 20.115 & 6.394 \\
\hline $7-10-88$ & 922 & 5.80 & 14.41 & 7.832 & 38.621 & 8.703 & 6.153 & 10.140 & 3.721 & 0.051 & 1.870 & 85.776 & 28.339 & 8.567 \\
\hline $7-17-86$ & 929 & 5.60 & 14.68 & 7.868 & 38.883 & 8.789 & .153 & 16.237 & 3.745 & 6.951 & 1.889 & 88.381 & 28. 591 & 6.804 \\
\hline $7-24-86$ & 936 & 4.76 & 14.78 & 7.701 & 37.212 & 8.864 & 6.154 & 10.341 & 3.754 & 6.052 & 1.908 & 87.968 & 20.716 & 6.698 \\
\hline $8-97-86$ & 951 & 2.70 & 14.88 & 7.727 & 37.492 & 8.907 & 6.154 & 10.423 & 3.798 & 6.652 & 1.816 & 87.988 & 20.815 & 6.748 \\
\hline $8-13-86$ & 958 & 7.50 & 15.16 & 7.798 & 37.928 & 9.627 & 0.155 & 10.852 & 3.912 & 6.653 & 1.842 & 89.468 & 21.198 & 6.890 \\
\hline $8-28-88$ & 971 & 8.28 & 15.48 & 7.875 & 38.514 & 9.158 & 0.157 & 10.902 & 4.039 & 0.053 & 1.870 & 81.648 & 21.427 & 7.044 \\
\hline $9-16-86$ & 984 & 7.10 & 16.75 & 7.942 & 99.692 & 9.271 & 6.158 & 11.119 & 4.149 & 0.054 & 1.895 & 92.468 & 21.704 & 7.178 \\
\hline $9-25-86$ & 999 & 8.68 & 18.60 & 8.694 & 39.485 & 9.376 & ๑. 159 & 11.320 & 4.252 & 0.654 & 2.618 & 83.788 & 21.962 & 7.303 \\
\hline $10-62-86$ & 1086 & 5.10 & 18.19 & 8.953 & 39.823 & 9.458 & 0.160 & 11.475 & 4.331 & 0.056 & 2.038 & 94.808 & 22.161 & 7.399 \\
\hline $10-23-88$ & 1827 & 5.20 & 18.39 & 8.162 & 46.189 & 9.541 & 0.181 & 11.834 & 4.411 & 0.655 & 2.654 & 85.848 & 22.363 & 7.497 \\
\hline $11-66-86$ & 1041 & 3.10 & 16.51 & 8.131 & 40.407 & 9.590 & 0.182 & 11.755 & 4.581 & 0.055 & 2.865 & 98.497 & 22.487 & 7.552 \\
\hline $11-20-88$ & 1055 & 2.60 & 16.61 & 8.158 & 40.868 & 9.635 & 0.163 & 11.865 & 4.585 & 0.056 & 2.875 & 96.998 & 22.601 & 7.593 \\
\hline $12-10-88$ & 1075 & 2.50 & $16.7 \%$ & 8.179 & 40.797 & 9.679 & 0.164 & 11.971 & 4.885 & 0.658 & 2.685 & 97.534 & 22.709 & 7.633 \\
\hline $12-30-88$ & 1695 & 3.20 & 16.82 & 0.269 & 41.042 & 9.735 & 0.165 & 12.198 & 4.768 & 0.058 & 2.097 & 98.222 & 22.849 & 7.685 \\
\hline $1-19-87$ & 1189 & 1.60 & 16.88 & B. 225 & 41.164 & 9.763 & 0.168 & 12.174 & 4.820 & 0.058 & 2.103 & 98.568 & 22.018 & 7.711 \\
\hline $1-20-87$ & 1122 & 1.50 & 16.94 & 0.239 & 41.279 & 9.789 & 0.166 & 12.237 & 4.868 & 0.657 & 2.169 & 98.888 & 22.983 & 7.735 \\
\hline $2-89-87$ & 1136 & 1.36 & 16.99 & B. 254 & 41.388 & 9.814 & 6.167 & 12.298 & 4.914 & 0.057 & 2.114 & 99.200 & 23.044 & 7.753 \\
\hline
\end{tabular}


Lysimeter $\$ 2$ field chemistry

Portland III Cement

$\mathrm{Na}_{2} \mathrm{SO}_{4}$ Evaporator Concentrate

Drum 1-1

CLULATIVE LEACHED, $g$

\begin{tabular}{|c|c|c|c|c|c|c|c|c|c|c|c|c|c|c|}
\hline DATE & DAY & $\begin{array}{l}\text { ORAIN } \\
\text { liters }\end{array}$ & $\begin{array}{l}\text { CLTV } \\
\text { DRAIN } \\
\text { CA }\end{array}$ & JOC & Ca+. & $\omega_{\mathrm{g}++}$ & Sr. & $\mathrm{Na}+$ & K+ & B & $\mathrm{Cl}-$ & N03- & S04-- & Si \\
\hline$-26-84$ & 368 & 1.87 & 0.04 & 6.259 & 0.658 & 0.011 & 600 & 0.188 & 8. 882 & .068 & 8.603 & .960 & 8.848 & 0.624 \\
\hline $11-18-84$ & 321 & 8.68 & 0.07 & 6.347 & 0.079 & 0.018 & 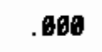 & 0.258 & 0.133 & .060 & 9.8B6 & 8.645 & 8.890 & 0.636 \\
\hline $1-24-85$ & 396 & 0.02 & 0.07 & 0.358 & 0.686 & 6.818 & .000 & 0.258 & 6. 135 & . 060 & 0.006 & 0.648 & e. 691 & 0.836 \\
\hline $2-13-85$ & 410 & 0.08 & 6. 87 & 6.350 & 8.880 & 0.018 & .060 & 0.258 & 6.135 & .060 & 6.868 & 8.048 & 6. .991 & 0.038 \\
\hline $3-11-86$ & 438 & 8.60 & 6.67 & 0.350 & 0.080 & 0.018 & .000 & C. $25 B$ & 0.135 & .000 & 8.868 & 0.046 & 6. 891 & 0.638 \\
\hline $3-12-85$ & 437 & 9.68 & 0.07 & 0.350 & 8. 680 & 0.018 & .060 & C. 258 & t.135 & .001 & 0.066 & 6.946 & - 6.691 & 0.638 \\
\hline $3-29-86$ & 454 & 18.14 & 0.68 & 2.618 & 6.744 & 6.263 & 3.684 & 1.293 & 1.495 & . & 0.132 & 2.242 & 1.399 & 0.251 \\
\hline $4-64-85$ & 460 & 0.00 & 0.88 & 2.518 & 9.744 & 6.293 & 6.604 & 1.283 & 1.485 & .000 & 0.132 & 2.242 & 1.398 & .251 \\
\hline $4-12-85$ & 468 & 8.00 & 8.88 & 2.518 & 6.744 & 0.263 & 1.064 & 1.283 & 1.405 & .006 & 6.132 & 2.242 & 1.398 & e.251 \\
\hline $8-26-86$ & 637 & 67.78 & 2.88 & 18.278 & 8.169 & 1.485 & $.82 B$ & 2.743 & 1.604 & 0.001 & 8.681 & 12.584 & 6.598 & 1.288 \\
\hline $7-23-86$ & 670 & 0.80 & 2.88 & 10.278 & 6. 169 & 1.495 & 6.028 & 2.743 & 1.864 & 0.001 & 0.681 & $12.5 B 4$ & 6.599 & 1.268 \\
\hline $8-14-85$ & 592 & 29.39 & 3.89 & 14.225 & 11.884 & 2.681 & 0.655 & 5.837 & 2.170 & 0.002 & 1.281 & 17.096 & 22.028 & 1.819 \\
\hline $18-24-85$ & $B 63$ & 23.71 & 4.98 & 14.848 & 18.879 & 4.246 & $\theta .08 \theta$ & B. 143 & 2.597 & 1.603 & 1.873 & 26.131 & 44.793 & 2.291 \\
\hline $1-39-86$ & 781 & 17.14 & 5. 55 & 15.386 & 26.496 & 5.808 & 0.117 & 12.257 & 2.840 & 0.664 & 2.798 & 22.894 & 68.791 & 2.583 \\
\hline $2-22-68$ & 784 & 0.00 & 5.55 & 15.388 & 25.496 & 5.008 & 6.117 & 12.257 & 2.840 & 0.094 & 2.796 & 22.994 & 68.791 & 2.583 \\
\hline $2-28-88$ & 790 & 46.50 & 7.89 & 16.682 & 38.638 & 9.060 & 0.172 & 21.998 & 3.494 & 0.806 & 4.173 & 28.041 & 118.418 & 3.331 \\
\hline $3-87-88$ & 797 & 0.80 & 7.69 & 16.882 & 38.638 & 9.080 & .172 & 21.998 & 3.494 & 0.068 & 4.173 & 28.841 & 118.416 & .331 \\
\hline $3-13-86$ & 803 & 0.60 & 7.09 & 18.882 & 38.638 & 8.686 & 0.172 & 21.898 & 3.494 & 0.068 & 4.173 & 26.841 & 119.416 & .331 \\
\hline $3-21-86$ & 811 & 62.06 & 9.44 & 18.866 & 68.757 & 14.093 & .255 & 36.989 & 4.344 & 8.060 & 6.281 & 32.731 & 198.818 & 4.568 \\
\hline $3-28-88$ & 818 & 14.60 & 9.88 & 10.114 & 63.300 & 15.225 & 0.274 & 48.278 & 4.536 & 0.069 & 8.757 & 34.661 & 214.418 & 4.771 \\
\hline 4-83-86 & 824 & 16.60 & 10.36 & 19.434 & 86.645 & 16.033 & e. 287 & 42.881 & 4.673 & 0.010 & 7.697 & 35.811 & 228.916 & 4.986 \\
\hline $4-10-86$ & 831 & 11.80 & 10.78 & $19.78 \mathrm{~B}$ & 78.115 & 16.823 & 6.362 & 46.328 & 4.823 & 0.010 & 7.471 & 38.858 & 246.688 & 189 \\
\hline 4-17-88 & 838 & 9.96 & 11.12 & 20.674 & 73.035 & 17.656 & 0.314 & 47,491 & 4.847 & 6.011 & $7.7 m$ & 36.911 & 251.916 & .339 \\
\hline $4-25-88$ & 848 & 10.48 & 11.52 & $2 \theta, 414$ & 75.786 & 18.398 & 8.325 & 56. 012 & 6.824 & 8.011 & 7.986 & .152 & 283.422 & 8.670 \\
\hline $5-61-88$ & 852 & 7.05 & 11.78 & 26.896 & 78.884 & 19.274 & 8.338 & 54.739 & 5.110 & 0.012 & 8.222 & .615 & .619 & 5.739 \\
\hline $8+88$ & 859 & 9.28 & 12. & 21.510 & 92.880 & .427 & 0. 354 & 967 & .222 & 812 & 8.536 & 37.989 & 2.828 & 5.860 \\
\hline $5-15-86$ & 866 & 8.74 & 12.47 & 22.099 & 88.892 & .522 & 370 & 784 & 29 & .013 & 6.823 & .439 & 24.811 & 6.169 \\
\hline $5-22-86$ & 873 & 7.44 & 12.75 & 22.600 & 89.938 & 22.454 & 0.384 & 71.749 & 5.429 & 0.613 & 9.872 & 38.821 & 342.841 & 8.348 \\
\hline
\end{tabular}


Lysimeter \#2 field chemistry (continued)

portland III Cement

$\mathrm{Na}_{2} \mathrm{SO}_{4}$ Evaporator Concentrate

Drum 1-1

CUMATIVE LEACHED, $g$

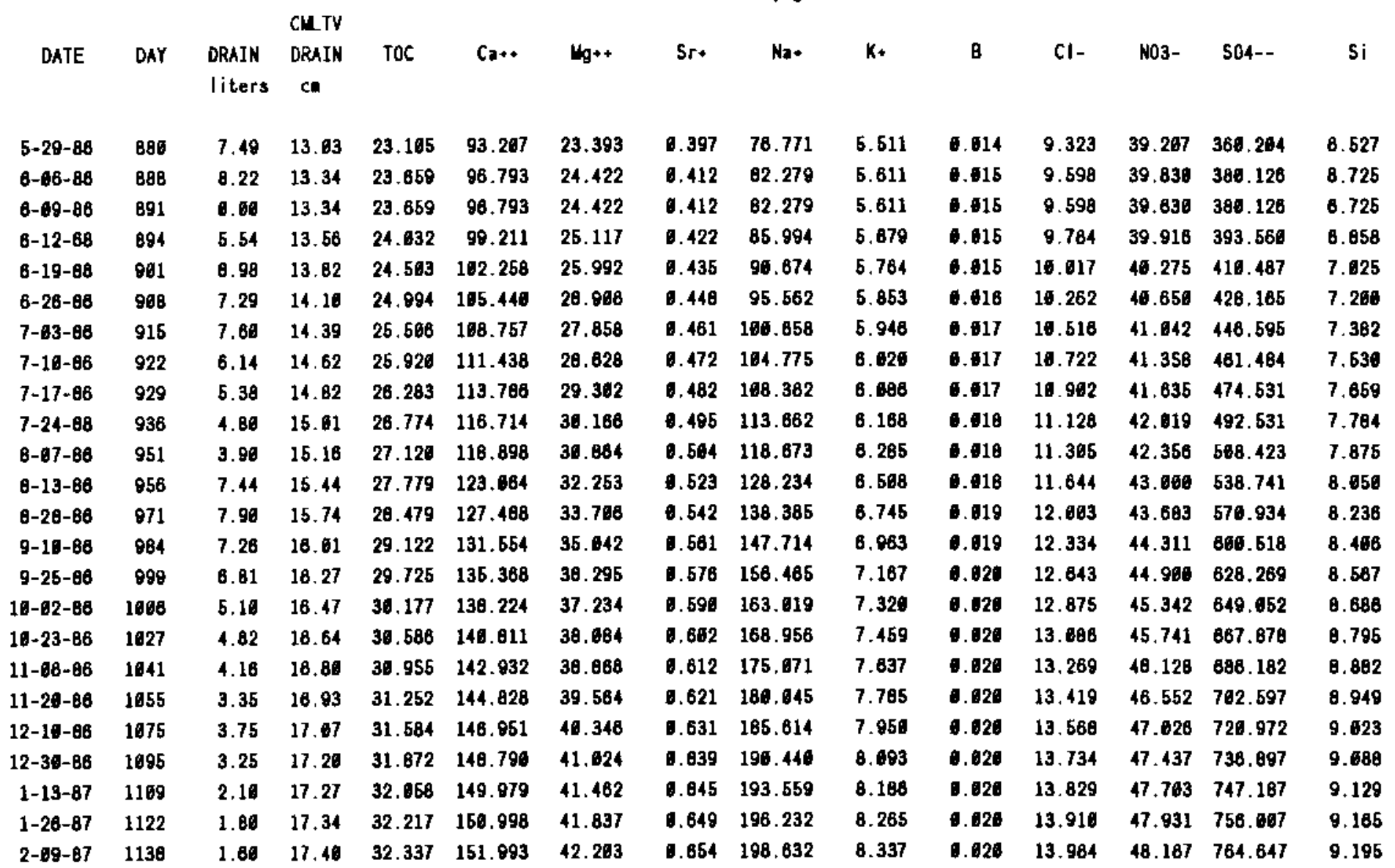


Lysimeter $\$ 3$ field chemistry

Portland III Cement

$\mathrm{Na}_{2} \mathrm{SO}_{4}$ Evaporator Concentrate w/ Ion Exchange Resin

Drum 2-1

CUMUATIVE LEACHED, g

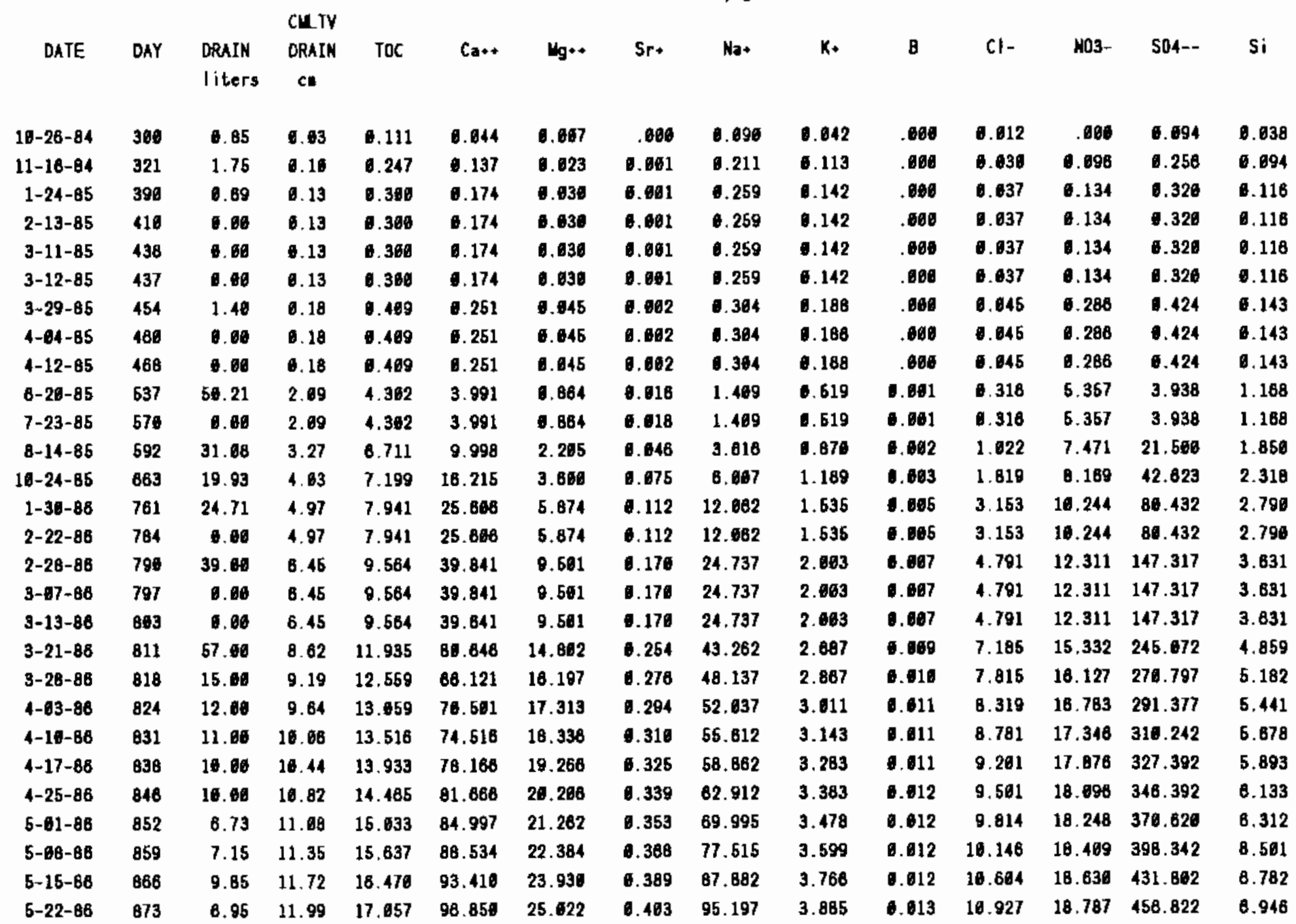


Lysimeter \#3 field chemistry (continued)

Portland III Cement

$\mathrm{Na}_{2} \mathrm{SO}_{4}$ Evaporator Concentrate w/ Ion Exchange Resin

Drum 2-1

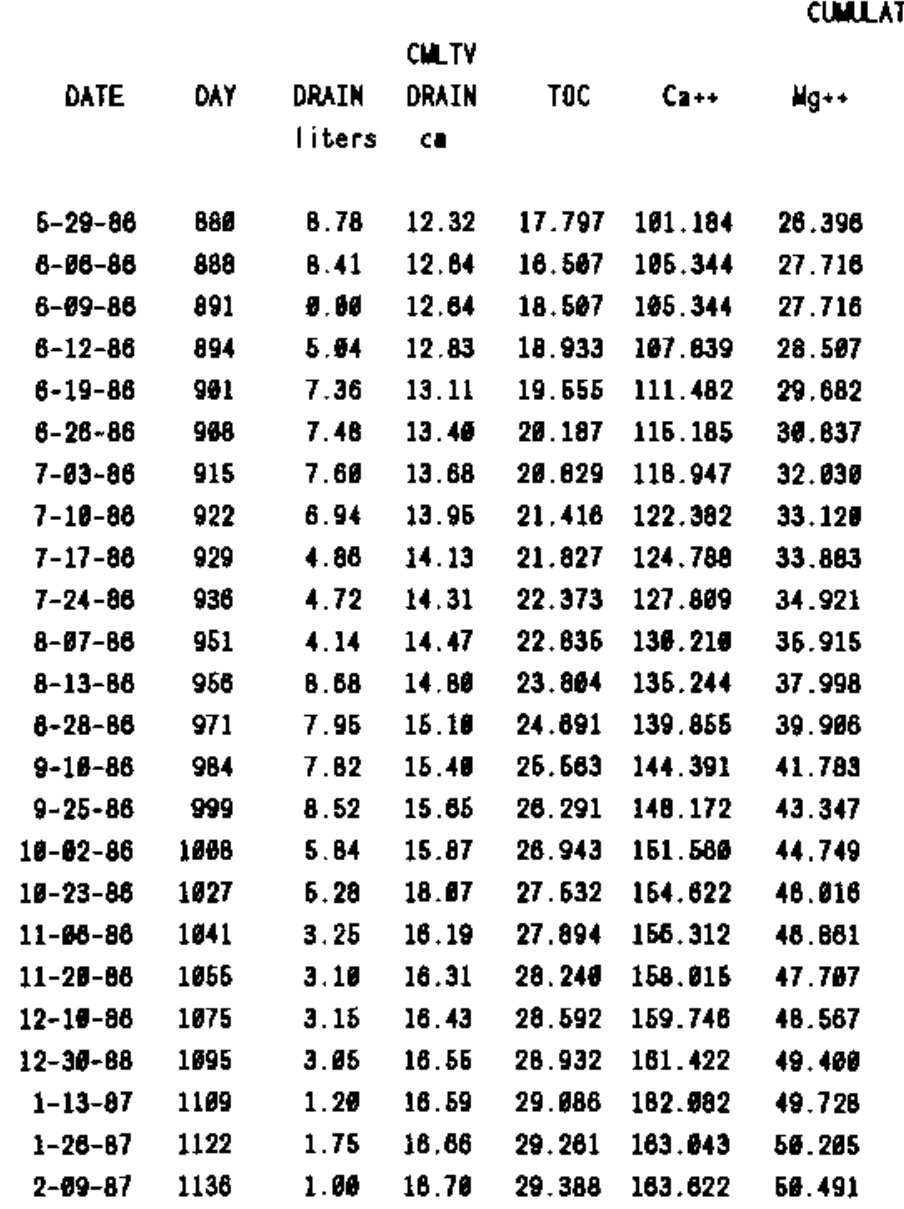

\begin{tabular}{|c|c|}
\hline Sr. & $\mathrm{Na} \cdot$ \\
\hline 0.421 & 164.4 \\
\hline 0.439 & 113.28 \\
\hline 0.439 & 113.25 \\
\hline 0.450 & 118.58 \\
\hline D. 485 & 128.3 \\
\hline 0.481 & 134.1 \\
\hline$\nabla .496$ & 142.1 \\
\hline 0.511 & 149.4 \\
\hline 6.521 & 154.6 \\
\hline 8.634 & 162.8 \\
\hline 0.645 & 171.6 \\
\hline 6.669 & 190.6 \\
\hline 6.690 & 207.7 \\
\hline 0.612 & 224.8 \\
\hline 0.629 & 238.9 \\
\hline 0.645 & 251.6 \\
\hline 0.659 & 283.1 \\
\hline 0.686 & 271.7 \\
\hline 0.678 & 280.5 \\
\hline 0.885 & 289.4 \\
\hline 6.693 & 298.1 \\
\hline 6.898 & 2a1 \\
\hline 6.760 & 368. \\
\hline 6.763 & 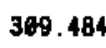 \\
\hline
\end{tabular}

K+

B

Cl- NO3- SD4--

$\mathrm{Si}$

$4.033 \quad 0.013 \quad 11.335$

$4.176 \quad 0.013 \quad 11.725$

$4.176 \quad .013 \quad 11.726$

$4.282 \quad 0.013 \quad 11.960$

$4.387 \quad 0.013 \quad 12.382$

$4.514 \quad .013 \quad 12.659$

$4.843 \quad 0.014 \quad 13.063$

$4.7810 .014 \quad 13.328$

$4.844 \quad 0.614 \quad 13.652$

$4.957 \quad 0.014 \quad 13.849$

5.148

5.541

6.01414 .137

$0.614 \quad 14.740$

5.992

6. 258

6.655

6.621

0.61415 .293

.01415 .838

0.61416 .289

0.01416 .895

7.681

0.01417 .062

$0.014 \quad 17.369$

7.498

7.720

0.01417 .548

$9.014 \quad 17.798$

$7.9380 .014 \quad 18.925$

0.01418 .118

$0.014 \quad 18.252$

$18.984 \quad 488.348$

$19.173 \quad 518.598$

19.173518 .598

$19.286 \quad 536.742$

$19.452 \quad 583.238$

$19.628 \quad 590.186$

$19.791 \quad 617.526$

$19.947 \quad 642.510$

$29.058 \quad 669.066$

$20.185 \quad 685.922$

26.312711 .725

20.820787 .711

$20.902 \quad 018.989$

$21.188 \quad 889.428$

$21.411 \quad 911.482$

$21.819 \quad 949.150$

$21.806 \quad 983.286$

21.9621007 .996

22.2381032 .796

22.5181057 .998

$22.790 \quad 1682.306$

22.8971691 .098

23.0521105 .908

.401

7.461

7.535

7.739

7.928

0.129

8.313

0.442

8. 679

8.695

8. 938

9.160

9.379

8.562

9.725

9.873

9.961

10.039

16.119

8.145

6. 16 18.330

23.1821114 .396

10.228

10.270

10. 294 
Lysimeter \#4 field chemistry

Dow Polymer

$\mathrm{Na}_{2} \mathrm{SO}_{4}$ Evaporator Concentrate w/ Ion Exchange Resin

Druin 7-2

CUMUATIVE LEACHED, g

CULTY

\begin{tabular}{|c|c|c|c|c|c|c|c|c|c|c|c|c|c|c|}
\hline DATE & AY & $\begin{array}{l}\text { RAIN } \\
\text { iters }\end{array}$ & $\begin{array}{c}\text { DRAIN } \\
\text { C॥ }\end{array}$ & TOC & Ca.* & $\mathbf{H g}_{*+}$ & $5 r+$ & $\mathrm{Na}$ + & K. & B & cl- & N03- & SO4-. & Si \\
\hline $28-84$ & 398 & 1.10 & 6. 64 & ด. 378 & 0.068 & 0.020 & .060 & C. 293 & 0.190 & .806 & 0.006 & .000 & 0.100 & 0.037 \\
\hline$-16-84$ & 21 & 0.91 & 0.8 & 0.823 & 184 & 1. 849 & 0. 281 & 0.461 & 6. 399 & 0.001 & 0.041 & 8.858 & 0.344 & 8. 858 \\
\hline $1-24-85$ & 90 & 0.10 & $A . B B$ & 8.676 & . 182 & 0.855 & 6.601 & 0.494 & 0.430 & .061 & 6.648 & 0.959 & C. 391 & 0.862 \\
\hline $2-13-65$ & 410 & 6.06 & 6. 88 & .678 & 0.182 & 0.0 & .601 & 8. 494 & .439 & 6.001 & 0.948 & 0.059 & 6. 391 & 9.862 \\
\hline $3-11-85$ & 436 & $\theta .00$ & 8.68 & 8.670 & 0.182 & 0.056 & 0.001 & 9.494 & 0.439 & 1.001 & 0.048 & 0.658 & 6.391 & 8. 682 \\
\hline $3-12-85$ & 437 & 6. 99 & 0.88 & 0.670 & 6. 182 & 0.056 & 0. 801 & C. 494 & 0.439 & 0.081 & 0.048 & 8.659 & C. 391 & 9. 862 \\
\hline $3-29-85$ & 454 & 60 & 0.12 & B. 939 & ब. 330 & 6.100 & .062 & 0.580 & 0.725 & 0.001 & 0.129 & G. 187 & 6.838 & 0.875 \\
\hline $1-84-85$ & 468 & .06 & 9.12 & 8. 939 & 6. 330 & A. 100 & 8.602 & 1. 699 & 6.726 & 0.001 & 0.129 & d. 187 & 6. 838 & 0.075 \\
\hline$-12-86$ & 6 & 80 & $\theta$ & 0.030 & 1.336 & 0.180 & 02 & 1. 699 & 0.725 & 0.001 & C.128 & 0.187 & 6.838 & 6.075 \\
\hline$-20-85$ & 17 & 78 & 32 & & & & 0.853 & 2.583 & 1.326 & 6.001 & 2.951 & 6.178 & 19.675 & 6. 884 \\
\hline 7-23-85 & & & & 494 & & 2.573 & 8.653 & 2.583 & 1.328 & 1. .001 & 2.951 & 8.178 & 19.876 & 1. 864 \\
\hline $3-14-85$ & 692 & 27.5 & 3.3 & 3.896 & 17.847 & 4.607 & 8. 883 & 4.392 & 1.868 & 0.062 & 4.519 & 8.321 & 33.844 & 1.326 \\
\hline$-24-85$ & 63 & 27.5 & 4.41 & 31.298 & 25.899 & 5.698 & 9.120 & 7.114 & 2.981 & 0.065 & 8.386 & 9.751 & $\mathbf{6 2 . 6 1 7}$ & 1.807 \\
\hline $1-30-$ & 81 & 24.71 & 5.35 & 37.951 & 38.672 & 9.034 & .173 & 7.749 & 2.501 & 8. 068 & 7.912 & 12.914 & 107.725 & 2.162 \\
\hline-22 & 84 & 6.00 & 5.36 & 37.951 & 38.072 & 9.634 & .173 & 17.746 & 2. 581 & 9. 980 & 7.012 & 12.914 & 107.725 & 2.152 \\
\hline $2-28-88$ & 790 & 5.60 & 7.44 & 62.757 & 57.652 & 3.984 & .255 & 8.743 & 3.243 & 0.014 & 16.167 & 16.819 & 189.400 & 3.065 \\
\hline$-67-88$ & 797 & 60.68 & 9.34 & 68.217 & 75.452 & 18.484 & .328 & 4.118 & 3. 818 & 6.018 & 12.217 & 9. 389 & 283.850 & 3.780 \\
\hline$-13-88$ & & 0.66 & 9.34 & 66.217 & 75.452 & 9.464 & .328 & 4.018 & 3.918 & 6.619 & 2.217 & 0.369 & 283.858 & 3.780 \\
\hline$-21-86$ & & 8.00 & 10.86 & 78.085 & 89.892 & .884 & 0.387 & & 4.458 & 0.824 & 3.857 & 3.269 & 323.856 & 4.480 \\
\hline$-28-88$ & & .60 & 11.39 & .754 & 94.678 & .344 & 0.468 & & 4.847 & 0.125 & 14.431 & 4.203 & 343.848 & 4.817 \\
\hline$-63-86$ & 24 & & 11.81 & .716 & 98.692 & 4.334 & 0.424 & 8.475 & 4.798 & 0.027 & 14.882 & 24.984 & 368.175 & 4.787 \\
\hline$-16-86$ & 831 & 10.00 & 12.19 & $B 6,467$ & 162.152 & 25.234 & 6.439 & 79.930 & 4.931 & C. $\$ 2 B$ & 15.282 & 25.694 & 375.026 & 4.942 \\
\hline $4-17-86$ & 838 & 9.00 & 12.53 & 88.838 & 105.358 & 28.644 & 6.452 & 83.640 & 5.052 & 6.029 & 15.661 & 28.333 & 388.390 & 5.682 \\
\hline $4-25-86$ & 848 & 4.68 & 12.71 & 89.727 & 196.217 & & 0.456 & & 5.696 & 6. 829 & 15.740 & 28.398 & 391.794 & 5.160 \\
\hline $5-61-86$ & 852 & 7.46 & 12.99 & 91.574 & 108.892 & 26.888 & & & 5.161 & 0.030 & 15.891 & 6.712 & 398.454 & 5.298 \\
\hline 5-88-86 & 859 & 8.43 & 13.31 & 93.877 & 110.228 & & & & & & & 7.670 & 86.036 & 5.437 \\
\hline $5-15-86$ & 866 & 9.25 & 13.68 & 95.985 & & & & & & . 832 & & & 361 & 5. 599 \\
\hline $5-22-86$ & 873 & 7.22 & 13.94 & 97.787 & 114.463 & 28.156 & 0.490 & 93.138 & 5.373 & 0.832 & 18.482 & 27.770 & 426.859 & 5.725 \\
\hline
\end{tabular}


Lysimeter $\$ 4$ field chemistry (continued)

Dow Polymer

$\mathrm{Na}_{2} \mathrm{~S}_{4} 4$ Evaporator Concentrate w/ Ion Exchange Resin

Drum 7-2

CUMATIVE LEACHED, g

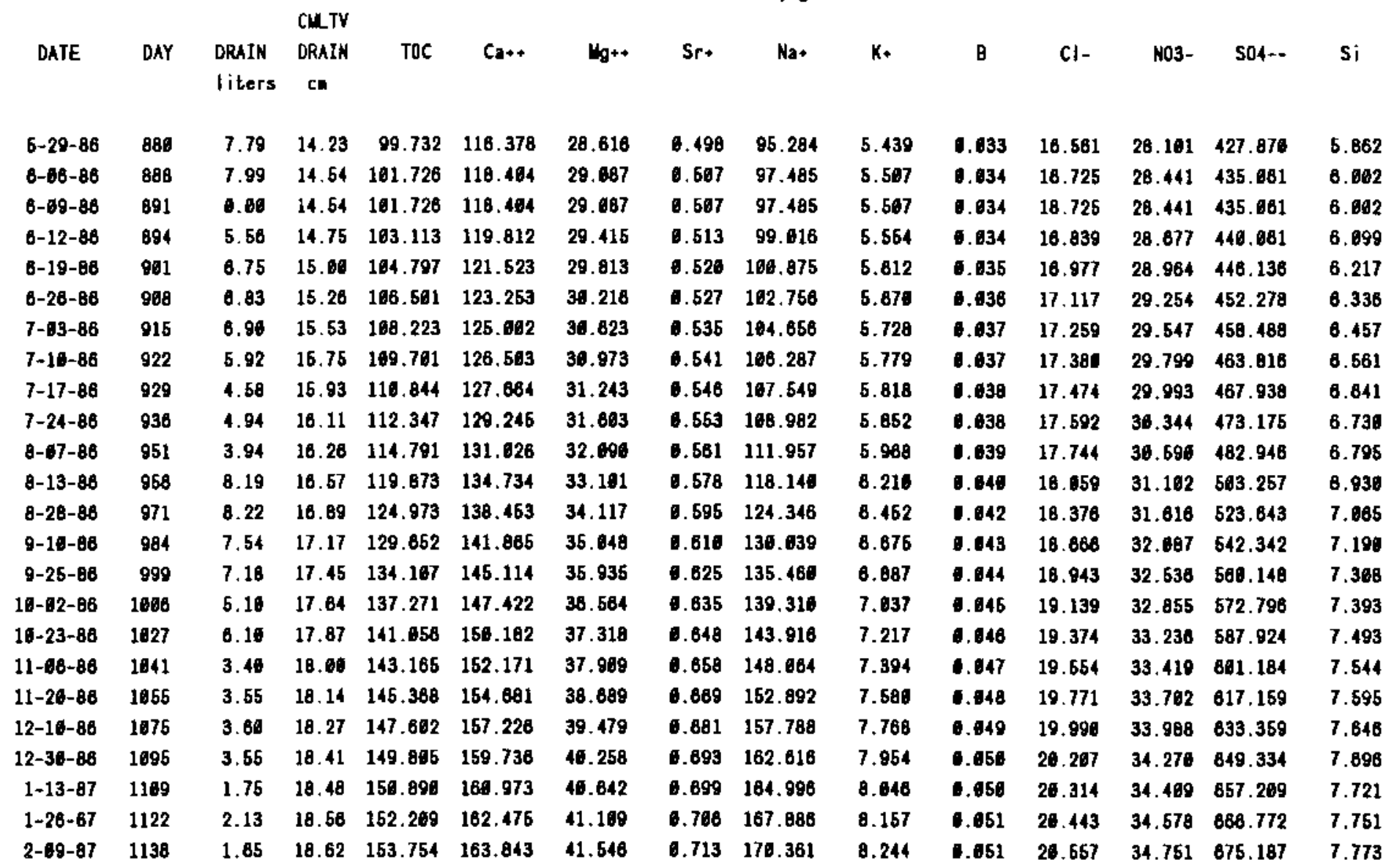


Lysimeter \#5 field chemistry

Bitumen

Boric Acid Evaporator Concentrate

Drum \#1

CUMLATIVE LEACHED, $g$

\begin{tabular}{|c|c|c|c|c|c|c|c|c|c|c|c|c|c|c|}
\hline DATE & DAY & $\begin{array}{l}\text { DRAIK } \\
\text { liters }\end{array}$ & $\begin{array}{l}\text { CILTV } \\
\text { DRAIN } \\
\text { CM }\end{array}$ & TOC & $\mathrm{Ca}_{\mathbf{a}+*}$ & $\mathrm{H}_{\mathrm{g}+4}$ & Sr* & $\mathrm{Na}+$ & K. & B & $\mathrm{Cl}-$ & N03- & S04-- & $\mathrm{Si}$ \\
\hline $6-26-84$ & 380 & 0.80 & 8.00 & 0.060 & 0.860 & 6.080 & 0.060 & 1.000 & 0.800 & 0.960 & 8.601 & 0.600 & 8.896 & 0.000 \\
\hline $11-16 \sim 84$ & 321 & 0.24 & 0.01 & 8.881 & 9.013 & 6.082 & .060 & 0.812 & 0.010 & .06 & 0.061 & 0.817 & 6.819 & 0.004 \\
\hline $1-24-85$ & 396 & 0.82 & 0.01 & 8.881 & 0.014 & 0.803 & .006 & 0.014 & 0.011 & .060 & 0.081 & 0.119 & 9.020 & 6.804 \\
\hline $2-13-85$ & 416 & 8.88 & 0.61 & 6.001 & 0.014 & 0.063 & .606 & 6.614 & 0.011 & .080 & 8.001 & 0.019 & 9.80 & 8.684 \\
\hline $3-11-85$ & 436 & 0.00 & 0. 1 & 0.001 & 0.014 & 0.03 & .809 & 0.614 & 0.011 & .000 & 6. 001 & 0.019 & 8. 620 & 0.004 \\
\hline $3-12-85$ & 437 & 0.00 & 0.01 & 8.801 & 0.014 & 6.683 & .860 & 0.014 & 6.611 & . & 0.801 & 8.019 & 0.820 & 0.004 \\
\hline $3-29-85$ & 454 & 0.60 & 0.01 & 6. .001 & 0.014 & 6.863 & .066 & 0.014 & B.811 & .680 & 1. 001 & 0.819 & 0.626 & 0.004 \\
\hline $4-64-85$ & 488 & 6.06 & 8.81 & 6.861 & 0.014 & 6. 693 & .060 & 0.014 & 0.011 & .000 & 8.601 & 0.019 & 0.028 & 0.094 \\
\hline $4-12-85$ & 488 & 6.80 & 0.81 & 0.601 & 0.014 & 0.063 & .000 & 6. 814 & 0.011 & .000 & 0. 861 & 6.919 & 0.028 & 0.804 \\
\hline $6-20-85$ & 537 & 0.80 & 6. 1 & 9.01 & 1.014 & 0.863 & .669 & 6.014 & 0.011 & .069 & 6. .01 & e. 019 & G. .28 & 0.004 \\
\hline $7-23-65$ & 570 & 0.88 & 0.11 & 0.001 & 0.014 & 0.863 & .868 & 0.614 & 0.611 & . & 0.001 & 0.119 & 0.928 & 0.004 \\
\hline $8-14-85$ & 592 & 8.83 & 8.61 & 8.001 & 0.015 & 6.863 & .000 & 0.015 & 0.012 & .060 & 8.601 & 0.021 & 0.023 & 0.004 \\
\hline $10-24-85$ & 863 & 0.56 & 0.83 & 0.064 & 0.042 & 6.868 & .060 & 0.042 & 0.033 & .000 & 8.883 & 0.657 & 0.862 & 8. 12 \\
\hline $1-3 \theta-88$ & 761 & 6.36 & 8.64 & 0.866 & 6.963 & 0.013 & .006 & 0.063 & 0.041 & .000 & 9.064 & อ. 108 & 8. 893 & 0.016 \\
\hline $2-22-86$ & 784 & 6.80 & 0.84 & 1. 8186 & c.663 & 0.013 & .000 & 0.053 & 0.041 & .800 & 0.084 & 6. 108 & 1. 893 & 0.018 \\
\hline $2-28-86$ & 799 & 29.25 & 1.15 & 0.184 & 1.952 & 0.455 & 0.069 & t. 961 & 6. 539 & .254 & t.128 & 2.814 & 2.038 & 0.474 \\
\hline $3-87-88$ & 797 & 85.68 & 3.82 & 0.581 & 6.147 & 1.436 & 0.029 & 2.788 & 1.615 & 0.818 & C. 385 & 8.827 & 6.381 & 1.491 \\
\hline $3-13-88$ & $B 83$ & 0.08 & 3.82 & 6. 581 & 8.147 & 1.436 & 0.029 & 2.786 & 1.816 & 0.818 & c. 395 & 0.827 & 8.381 & 1.491 \\
\hline $3-21-88$ & 811 & 38.60 & 5.97 & 6.813 & 8.669 & 2.010 & 6.641 & 3. 880 & 2.260 & 1.148 & 6. 553 & 12.342 & 8.888 & 2.686 \\
\hline $3-28-8 b$ & 818 & 12. & 5.53 & 4. 886 & 9.375 & 2.191 & 0.844 & 4.238 & 2.459 & 1.252 & 9.603 & 13.452 & 9.688 & 2.274 \\
\hline $4-83-86$ & 824 & 11.06 & 5.94 & 0.953 & 16.685 & .357 & 0.048 & 4.655 & 2.634 & 1.347 & 0.848 & 14.469 & 10.417 & 2.448 \\
\hline $4-19-86$ & 831 & 10.06 & 8.32 & 1.014 & 18.738 & .506 & B. 851 & 4.845 & 2.801 & 1.434 & 0.896 & 15.394 & 11.882 & 2.602 \\
\hline $4-17-86$ & 838 & 9.50 & 8.69 & 1.672 & 11.344 & 2.852 & 6.854 & 5.121 & 2.950 & 1.617 & 6. 729 & 18.273 & 11.714 & 2.751 \\
\hline $4-25-86$ & 848 & 11.26 & 7.11 & 1.140 & 12.865 & 2.811 & 0.657 & 5.346 & 3.031 & $1.71 \mathrm{~d}$ & 8.764 & 16.441 & 12.839 & 2.951 \\
\hline $5-81-86$ & 852 & 8.86 & 7.45 & 1.196 & 12.556 & 2.939 & 0.859 & 5.543 & 3.088 & 1.868 & Q. 795 & 17.168 & 12.325 & 3.112 \\
\hline $5-68-88$ & 859 & 8.61 & 7.77 & 1.251 & 13.694 & 3.065 & 6. 862 & 5.736 & 3.104 & 2.817 & 0.828 & 17.878 & 12.894 & 3.271 \\
\hline $5-15-86$ & 866 & 9.16 & 8.12 & 1.316 & 13.867 & & 8.085 & & 3.143 & 2.179 & 9. 858 & 18.632 & 2.962 & 3.439 \\
\hline $5-22-88$ & 873 & 7.41 & 2. 40 & 1.357 & 14.130 & 3.397 & 0.067 & 6.169 & 3.174 & 2.310 & c.885 & 19.243 & 13.143 & 3.578 \\
\hline
\end{tabular}


Lysimeter \#5 field chemistry (continued)

Bitumen

Boric Acid Evaporator Concentrate

Drum \#1

CUNULATIVE LEACHED, 9

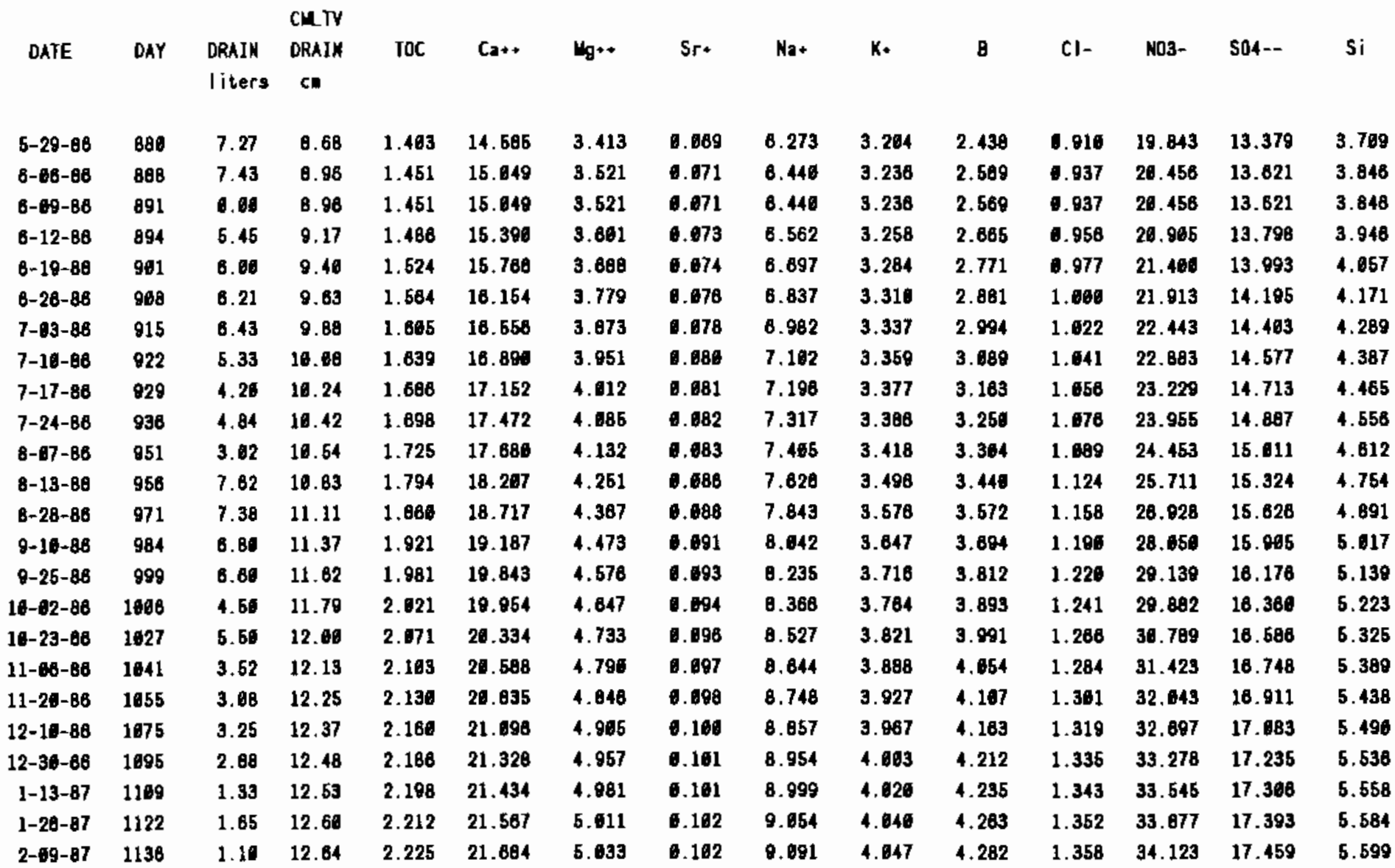


Lysimeter \#6 field chemistry

Bitumen

Boric Acid Evaporator Concentrate

Drum \#2

CLULATIVE LEACHED, $\mathbf{g}$

CULTV

\begin{tabular}{|c|c|c|c|c|c|c|c|c|c|c|c|c|c|c|}
\hline DATE & DAY & $\begin{array}{l}\text { DRAIN } \\
\text { liters }\end{array}$ & DRAIN & TOC & $\mathrm{Ca}+$. & $u_{g} *$ & St. & $\mathrm{Ma}$. & $K_{*}$ & B & Cl- & N03- & SO4-- & Si \\
\hline $26-84$ & 390 & 0.95 & 6.64 & 0.010 & 0.882 & 0.026 & .680 & 0.053 & 0.839 & . 860 & 8.695 & 0.681 & 0.059 & 0.617 \\
\hline $11-16-84$ & 321 & 1.60 & 6.89 & 6.728 & อ. 212 & c. 651 & 0.001 & 8.136 & 0.172 & .000 & ๑. 012 & 0.289 & 6.153 & 0.643 \\
\hline $1-24-85$ & 390 & 6.15 & 0.10 & 0.627 & . .225 & 1.654 & 6.061 & 0.145 & 6.168 & .068 & 6. .12 & ๑.221 & 8.162 & 0.045 \\
\hline 2-13-85 & 410 & 0.00 & 0.16 & 0.627 & .225 & 8. 854 & 0.061 & 8.145 & 0.108 & .060 & 0.612 & - .221 & 6. 182 & 9.045 \\
\hline $3-11-85$ & 438 & 0.00 & 0.18 & 0.827 & C. 225 & 0.054 & 0.601 & 6.146 & $0.18 B$ & .600 & 0.612 & 0.221 & a. 182 & 0.045 \\
\hline $3-12-85$ & 437 & 0.68 & 0.16 & 6. 827 & 8.226 & 6.054 & 0.801 & 0.146 & 9.188 & .606 & 0.812 & c.221 & 0.162 & 6.045 \\
\hline $3-29-85$ & 454 & 8.68 & 0.10 & 6. 127 & 8.225 & 1.654 & 0.001 & D. 145 & 6.168 & .060 & 9.812 & e. 221 & 0.162 & 0.045 \\
\hline $4-84-85$ & 486 & 0.00 & 9.10 & $\$ .627$ & 8. 225 & 1.654 & 0.601 & 0.145 & 6.168 & .860 & C.12 & 8.221 & 0.162 & 0.845 \\
\hline $4-12-85$ & 468 & 0.06 & 6.10 & 6. 627 & 0.225 & 0.054 & 6. 061 & 0.145 & 6.160 & .060 & 6.012 & t. 221 & 8. 162 & 0.645 \\
\hline $8-28-85$ & 537 & 0.00 & e.18 & 1. 827 & 6.225 & 0.054 & 0.001 & b.146 & $8.18 \mathrm{~B}$ & .806 & 0.012 & 0.221 & 6.162 & 0.045 \\
\hline $7-23-85$ & 578 & 0.00 & 0.10 & 6.827 & C. 225 & 0.864 & 0.801 & 0.146 & 0.188 & .600 & 0.012 & 0.221 & 0.182 & 0.045 \\
\hline $8-14-85$ & 592 & 1.00 & 0.14 & 0.838 & 0.311 & 0.075 & 8.882 & 8.200 & 0.149 & .000 & 8.617 & 6. 386 & U.225 & 0.883 \\
\hline $18-24-85$ & 663 & 8.36 & . 15 & 0.041 & 1336 & A. 601 & 0. 602 & 0.212 & 6.158 & .006 & 0.018 & d. 342 & .242 & e. 887 \\
\hline $1-36-86$ & 761 & 11.48 & 6. 58 & D. 182 & 1.287 & I.311 & 6.807 & 0.882 & 6.341 & 5.661 & 0.074 & 2.153 & 0.941 & B.227 \\
\hline$-22-88$ & 784 & t. & 0.58 & 6. 182 & 1.287 & 1.311 & 0.967 & 6882 & 6.341 & 0.861 & 6.074 & 2.163 & .041 & 0.227 \\
\hline $2-28-86$ & 798 & 24.00 & 1.58 & 6.415 & 3.174 & 1.769 & 0.616 & 1.238 & c. 695 & 0.288 & 8.194 & 4.349 & 2.681 & 0.819 \\
\hline $3-97-86$ & 797 & 86.00 & 3.97 & 1.101 & 8.283 & 2.010 & 0.640 & 2.981 & 1.289 & 1.694 & 0.519 & 16.298 & 5.188 & 1.602 \\
\hline $3-13-86$ & 863 & 119.80 & 8.49 & 2.356 & 17.636 & 4.283 & 0.885 & 8.114 & 2.536 & 2.558 & 1.114 & 21.185 & 10.821 & 3.627 \\
\hline $3-21-88$ & B11 & 44.06 & 18.18 & 2.821 & 21.096 & 5.124 & 0.101 & 7,280 & 3.098 & 3.898 & 1.334 & 25.211 & 12.911 & 4.347 \\
\hline $3-28-88$ & B1B & 16.00 & 10.74 & 2. 979 & 22.274 & 5.416 & 0.107 & 7.678 & 3.158 & 3.286 & 1.469 & 26.683 & 13.823 & .592 \\
\hline $4-83-86$ & B24 & 14.69 & 11.27 & 3.127 & 23.374 & 5.878 & 0.112 & .649 & 3.386 & .452 & 1.479 & 7.864 & 14.288 & 4.821 \\
\hline 4-10-86 & 831 & 12.86 & 11.72 & 3. 253 & 24.317 & 5.967 & $0.11 \mathrm{~B}$ & 8. 387 & 3.433 & 3.600 & 1.539 & 28.982 & 14.858 & 5.817 \\
\hline $4-17-86$ & 838 & 11.00 & 12.14 & 3.369 & 25.102 & 7 & 121 & 8.858 & 3.549 & 3.735 & 1.594 & 29.980 & 16.381 & 5.197 \\
\hline $4-25-86$ & 846 & 13.75 & 12.86 & 3.457 & .262 & 6.367 & 4.125 & 8. 919 & 3.819 & 4.872 & 1.865 & 36.313 & 15.848 & 5.455 \\
\hline $5-81-86$ & 852 & 8.78 & 13.00 & & 28.961 & 8.635 & 6.128 & 9.188 & 3.858 & 4.337 & 1.711 & 31.257 & 16.169 & 5.836 \\
\hline $6-68-86$ & 859 & 16.51 & 13.48 & 3.599 & 27.737 & 6.736 & 6.132 & 9.334 & 3.887 & 4.856 & 1.786 & 32.388 & 18.552 & 5.839 \\
\hline & 866 & 18.06 & $13.7 \mathrm{~B}$ & 3.872 & $2 B .533$ & 8.927 & 0.135 & 9.549 & 3.723 & 4.857 & 1.819 & 33.461 & 18.917 & 8.638 \\
\hline $5-22-88$ & 873 & 8.42 & 14.16 & 3.734 & 29.263 & 7.087 & $0.13 B$ & 9.738 & 3.753 & 5.212 & 1.863 & 34.388 & 17.225 & 8.268 \\
\hline
\end{tabular}


Lysimeter \#6 field chemistry (continued)

Bitumen

Boric Acid Evaporator Concentrate

Drum \#2

CUMLATIVE LEACHED, g

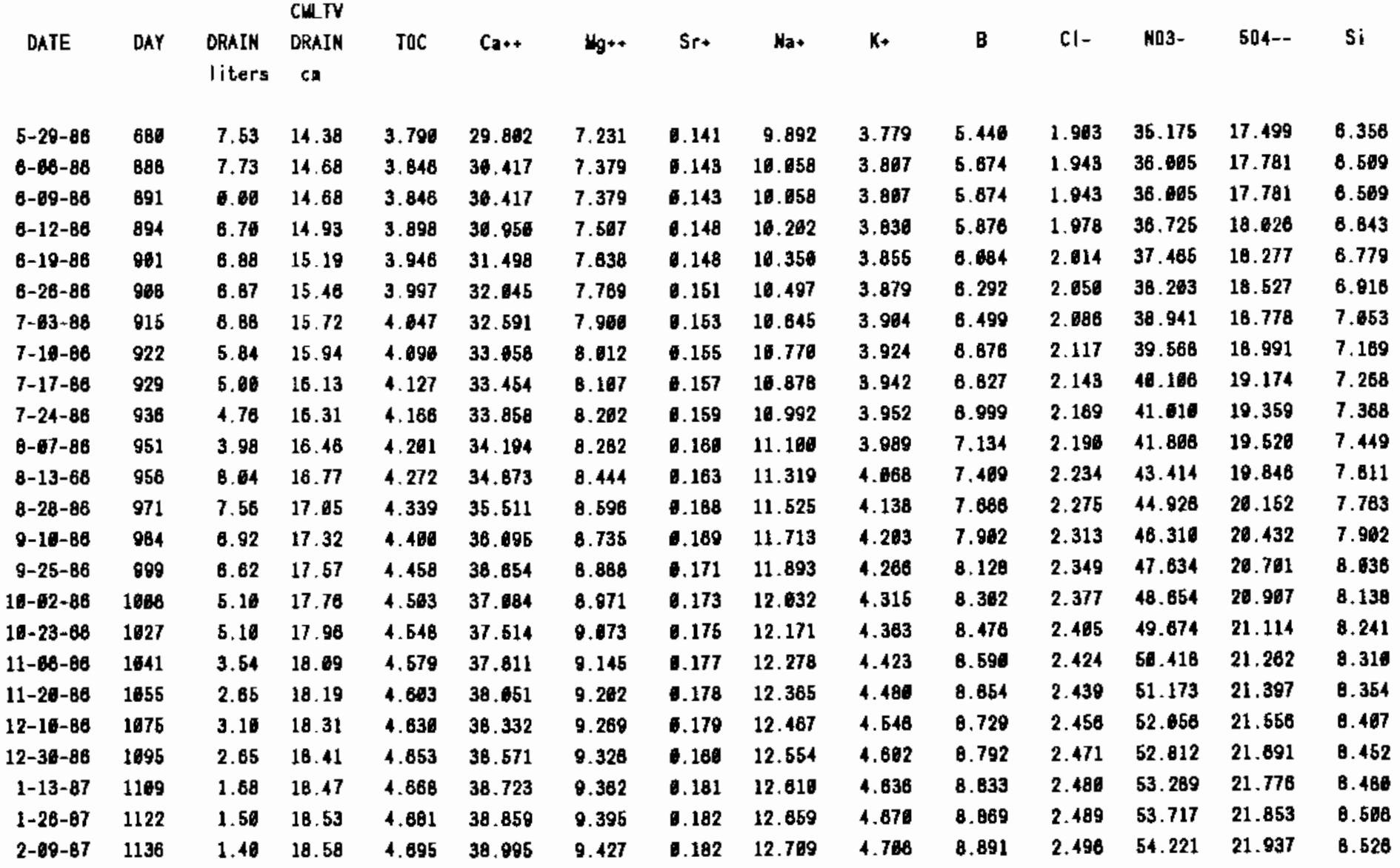


Lysimeter \#7 field chemistry

Masonry Cement

Boric Acid Concentrate

Drum 4-2

CUMATIVE LEACHED, g

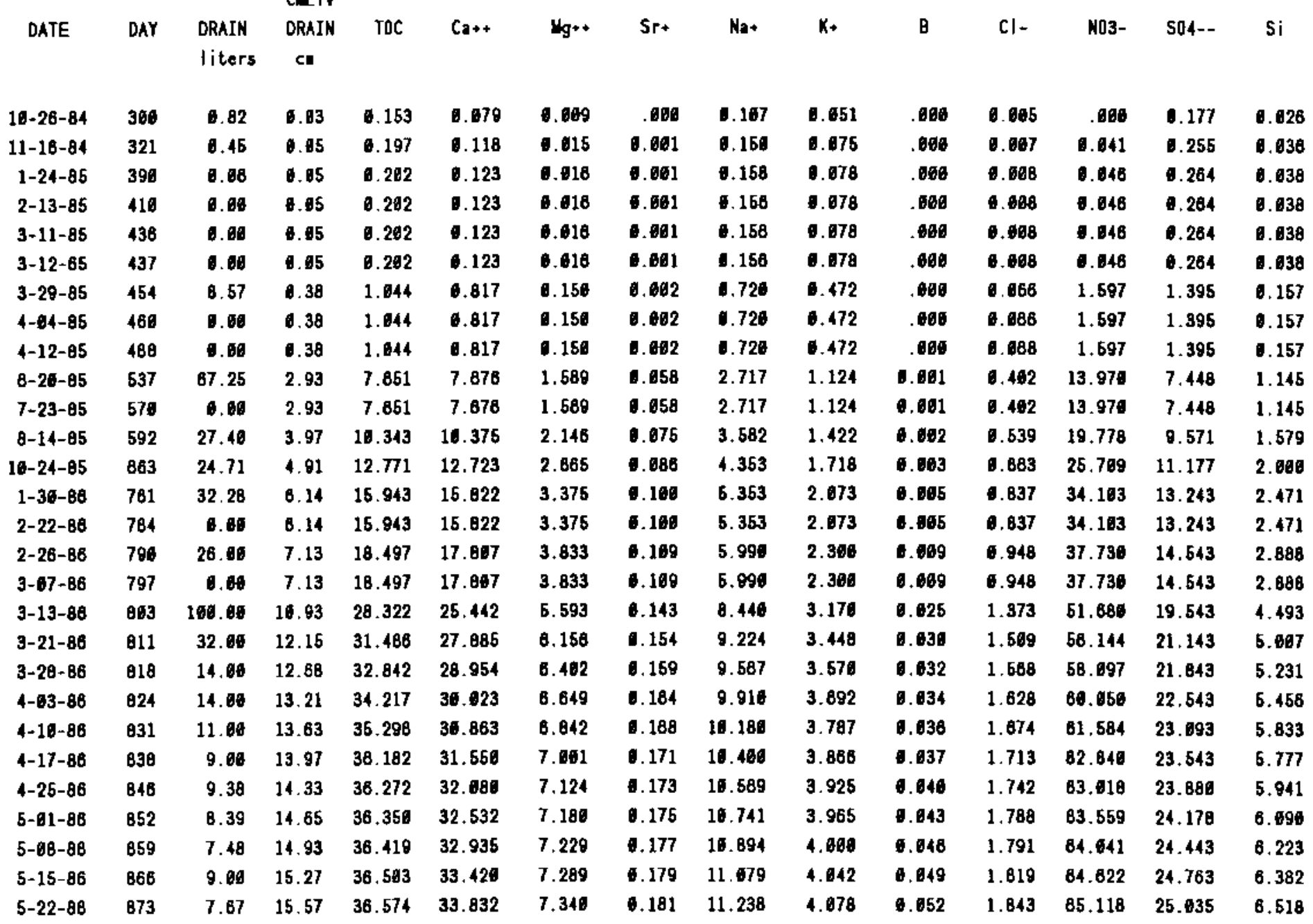


Lysimeter $\$ 7$ field chemistry

Masonry Cement

Boric Acid Concentrate

Drum 4-2

CUMLATIYE LEACHED, g

CUTY

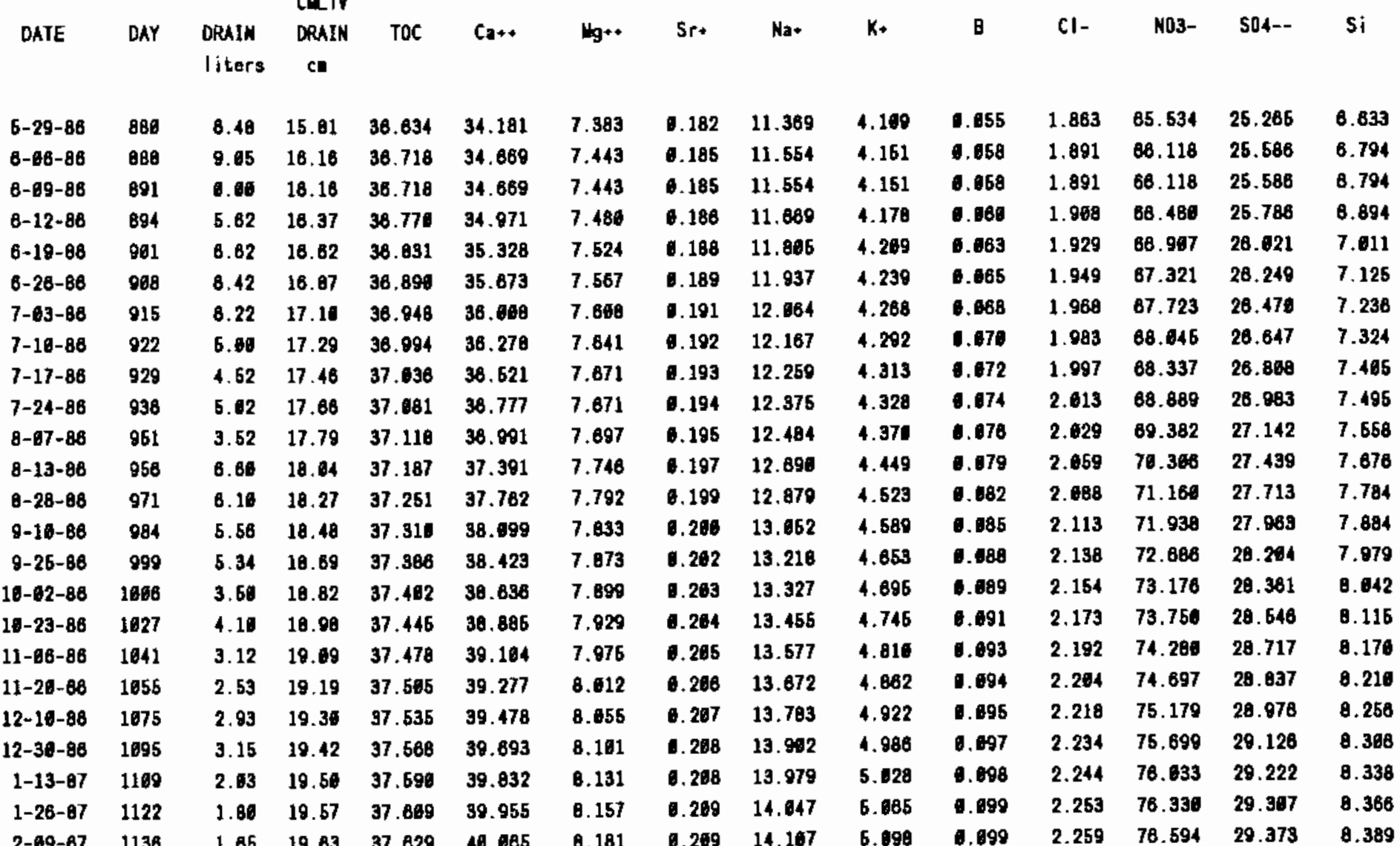


Lysimeter $\# 8$ field chemistry

Portland III Cement

$\mathrm{Na}_{2} \mathrm{SO}_{4}$ Evaporator Concentrate

Drum 1-2

CUMUATIVE LEACHED,

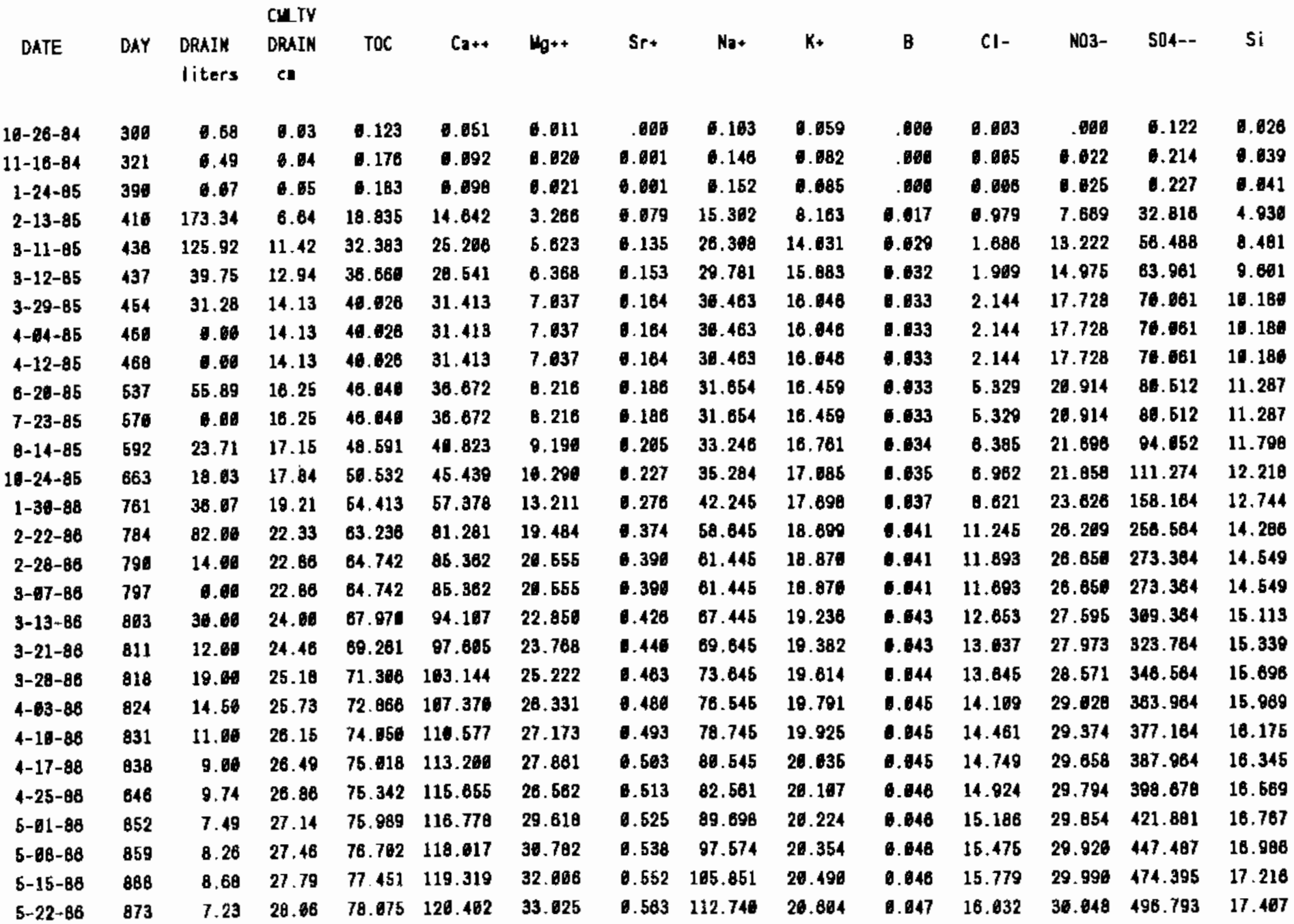


Lysimeter \#8 field chemistry (continued)

Portland III Cement

$\mathrm{Na}_{2} \mathrm{SO}_{4}$ Evaporator Concentrate

Drum 1-2

CUMATIVE LEACHED, 8

\begin{tabular}{|c|c|c|c|c|c|c|c|c|c|c|c|c|c|c|}
\hline DATE & DAY & $\begin{array}{l}\text { DRAIN } \\
\text { liters }\end{array}$ & $\begin{array}{l}\text { CLLTV } \\
\text { DRAIN } \\
\text { CA }\end{array}$ & TOC & Ca+t & $\mathbf{u g}_{\mathrm{g}+\boldsymbol{*}}$ & Sr+ & $\mathrm{Na}+$ & $\mathbf{k}$. & B & $\mathrm{Cl}-$ & N03- & S04-- & Si \\
\hline $29-88$ & 886 & 7.33 & 28.34 & 78.787 & 121.601 & 34.658 & 0.576 & 118.724 & 26.718 & 0.847 & 16.288 & 30.108 & 519.566 & 17.862 \\
\hline $1-90-88$ & 888 & 10.38 & 28.74 & 79.863 & 123.057 & 35.521 & 8. 591 & 128.817 & 26.882 & 0.047 & 18.851 & 36.189 & 551.683 & 17.878 \\
\hline$-69-86$ & 891 & 0.06 & 28.74 & 78.863 & 129.857 & 36.521 & ๑. 591 & 129.817 & 20.882 & 0.047 & 18.651 & 30.189 & 551.883 & 17.876 \\
\hline $3-12-86$ & 894 & 5.98 & 28.96 & 86.112 & 123.942 & 3.353 & 8.860 & 195.242 & 28.974 & 0.047 & 18.058 & 38.236 & 569.953 & 18.033 \\
\hline $8-19-68$ & 981 & 7.72 & 29.25 & 86.778 & 125.160 & 37.441 & 6.612 & 142.863 & 21.695 & 0.047 & 17.128 & 36.298 & 593.885 & 18.237 \\
\hline$\theta-28-68$ & 998 & 7.78 & 29.55 & 1.448 & 128.204 & 38.535 & 0.825 & 149.999 & 21.217 & .047 & 17.400 & 30.386 & 817.928 & 18.443 \\
\hline $7-63-86$ & 915 & 7.40 & 29.83 & 82.687 & 127.374 & 39.578 & 6.838 & 167.856 & 21.333 & .048 & 17.859 & 30.419 & 848.880 & 18.839 \\
\hline $7-10-88$ & 922 & 5.80 & 30.06 & 82.577 & 128.228 & 46.378 & 8.846 & 182.476 & 21.423 & .048 & 17.857 & 36.485 & 858.478 & 18.798 \\
\hline 7-17-88 & 929 & 5.92 & 36.27 & 83.088 & 129.114 & 41.214 & 6.854 & 189.116 & 21.616 & 6.648 & 18.085 & 36.512 & 878.828 & 18.948 \\
\hline$-24-88$ & 938 & 4.88 & 30.46 & 83.748 & 129.338 & 42.198 & d. 885 & 178.871 & $21.62 B$ & 0.048 & 18.380 & 30.522 & 780.890 & 18.887 \\
\hline $3-67-86$ & 951 & 9.84 & 36.59 & 84.168 & 136.245 & 42.980 & 1. 672 & 183.387 & 21.781 & 6.648 & 18.662 & $36.85 \theta$ & 721.248 & 18.194 \\
\hline $1-13-86$ & 958 & 58 & 3.88 & 86.067 & 132.834 & 4.628 & d. 8.88 & 197.789 & 22.085 & 6.648 & 18.885 & 36.927 & 781.793 & 19.464 \\
\hline $3-28-86$ & 871 & 7.30 & 1.18 & .817 & 133.758 & 46.616 & 0.783 & 211.639 & 22.377 & 0.648 & 19.253 & 31.180 & 860.848 & 19.807 \\
\hline $8-16-88$ & 884 & 38 & 1.46 & .522 & 136.257 & 47.313 & 0.718 & 223.723 & 22.831 & 0.648 & 19.675 & 31.412 & 834.874 & 19.784 \\
\hline -25-88 & 999 & 18 & 1.84 & .288 & 136.716 & 40.573 & 8.729 & 235.485 & 22.878 & 0.648 & 19.887 & 31.631 & 867.937 & 19.858 \\
\hline $.02-88$ & 1066 & 89 & 31.82 & 87.751 & 137.872 & 18.573 & 1.739 & 244.775 & 23.074 & 0.848 & 26.134 & .985 & 894.152 & 26.092 \\
\hline $23-88$ & 1827 & .76 & 32.60 & & & & 0.749 & 253.765 & 23.262 & 1.840 & 6.371 & 972 & 297 & 26.223 \\
\hline$-86-86$ & 1841 & 76 & .15 & & 148. & 18 & 9.758 & 281.801 & 23.473 & 1.048 & 28.656 & 2.231 & .353 & 26.319 \\
\hline $20-86$ & & 65 & & & 142.665 & 24 & 0.762 & 287.938 & 23.840 & 0.848 & 26.782 & 32.529 & 957.738 & 26.393 \\
\hline$-18-88$ & & 30 & 39 & 394 & 661 & 2.628 & 0.769 & 274.777 & 23.822 & 0.848 & 26.860 & 32.851 & 978.548 & 26.474 \\
\hline $12-38-88$ & & 16 & & 38 & 3 & .284 & 9.778 & 281.210 & 23.992 & 0.048 & 21.099 & 33.153 & 994.218 & 28.659 \\
\hline $1-13-87$ & 1109 & 86 & & .938 & 145.848 & 87 & 6.780 & 284.945 & 24.681 & 0.048 & 21.096 & 33.328 & 1804.478 & 26.594 \\
\hline $1-28-87$ & 112 & 55 & 2.63 & 19 & 146.572 & 53.996 & 6.783 & 288.101 & 24.177 & 0.849 & 21.178 & 93.479 & 1013.313 & 20.831 \\
\hline $2-69-67$ & 1138 & .36 & 32.88 & 8. 221 & 147.285 & 4.363 & 6.788 & 298.829 & 24.250 & 9.848 & 21.233 & 33.856 & 1821.143 & 20.883 \\
\hline
\end{tabular}


Lysimeter \#9 field chemistry

Portland III Cement

$\mathrm{Na}_{2} \mathrm{SO}_{4}$ Evaporator Concentrate $\mathrm{w} /$ Ion Exchange Resin

Drum 2-2

CUMUATIVE LERCHED, g

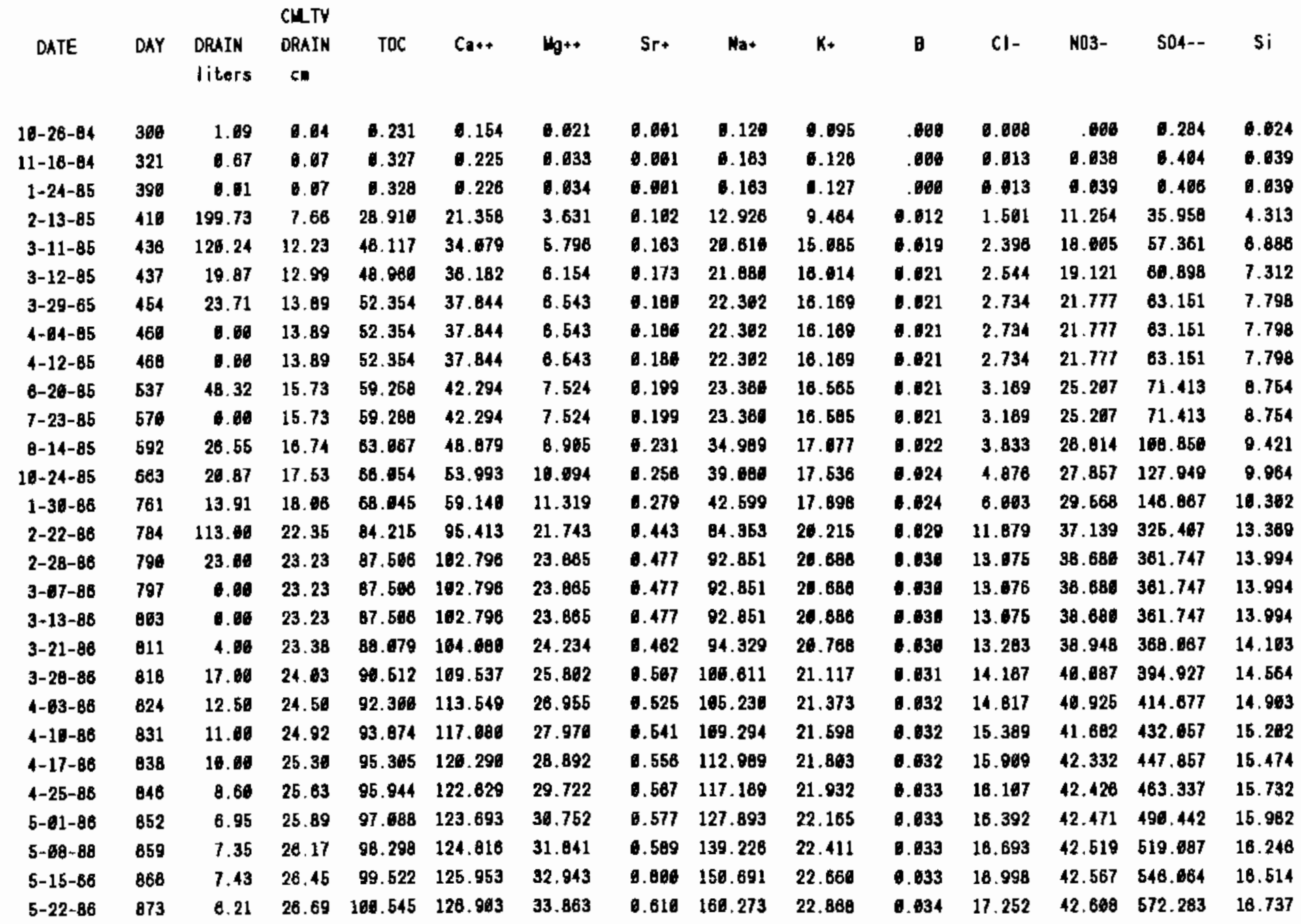


Lysimeter $\#$ field chemistry (continued)

Portland III Cement

$\mathrm{Na}_{2} \mathrm{SO}_{4}$ Evaporator Concentrate w/ Ion Exchange Resin

Drum 2-2

\begin{tabular}{|c|c|c|c|c|c|}
\hline \multirow{3}{*}{ DATE } & \multirow{3}{*}{ DAY } & \multicolumn{2}{|r|}{ CLTY } & \multirow{3}{*}{ TOC } & \multirow{3}{*}{$\mathrm{Cat+}$} \\
\hline & & & DRAIN & & \\
\hline & & liters & c: & & \\
\hline $5-29-86$ & 880 & B. 83 & 26.95 & 101.670 & 127.848 \\
\hline $6-66-86$ & 888 & 8.60 & 27.25 & 102.988 & 129.172 \\
\hline $8-88-86$ & 891 & 0.80 & 27.25 & 102.988 & 129.172 \\
\hline $6-12-86$ & 894 & 5.45 & 27.46 & 103.884 & 136.605 \\
\hline $8-19-86$ & 901 & 6.84 & 27.72 & 105.011 & 131.052 \\
\hline $8-26-86$ & 906 & 7.25 & 28.60 & 106.265 & 132.161 \\
\hline $7-63-88$ & 915 & 7.68 & 28.29 & 107.467 & 133.333 \\
\hline $7-10-86$ & 922 & 6.18 & 28.52 & 188.485 & 134.278 \\
\hline $7-17-68$ & 929 & 5.38 & 28.73 & 199.368 & 135.098 \\
\hline $7-24-86$ & 938 & 4.86 & 28.90 & 116.557 & 135.257 \\
\hline $8-97-86$ & 951 & 3.96 & 29.05 & 111.297 & 138.296 \\
\hline $0-13-88$ & 956 & 7.84 & 29.35 & 112.761 & 138.003 \\
\hline $0-28-88$ & 971 & 7.32 & 29.83 & 114.128 & 139.836 \\
\hline $9-10-86$ & 884 & 6.70 & 29.89 & 116.379 & 141.441 \\
\hline $9-25-88$ & 998 & 6.32 & 36.13 & 118.559 & 142.955 \\
\hline $14-12-86$ & 1006 & 4.10 & 36.28 & 117.325 & 143.937 \\
\hline $10-23-86$ & 1627 & 4.10 & 30.44 & 118.96 & 144.818 \\
\hline $1-86-86$ & 1041 & 3.34 & 30.68 & 118.714 & 146.495 \\
\hline $11-26-88$ & 1055 & 2.70 & 39.67 & 119.218 & 147.695 \\
\hline $12-10-86$ & 1076 & 3.28 & 39.79 & 119.816 & 148.225 \\
\hline $12-39-86$ & 1095 & 2.70 & 38.89 & 120.326 & 158.616 \\
\hline $1-13-87$ & 1109 & & 30.95 & 126.865 & 151.245 \\
\hline $1-26-87$ & 1122 & 1.23 & 31.00 & 120.834 & 161.839 \\
\hline 2-69-87 & 1136 & 1.30 & 31.65 & 128.988 & 152.494 \\
\hline
\end{tabular}

CUSULATIVE LEACHED, 9

Sr. Na.

K. 8 Cl- $203-$ so4-- Si

$\begin{array}{lllllllll}34.876 & 0.821 & 170.811 & 23.697 & 0.034 & 17.532 & 42.652 & 598.929 & 16.883\end{array}$

$\begin{array}{llllllllll}36.082 & 0.833 & 183.155 & 23.365 & 0.034 & 17.860 & 42.784 & 830.120 & 17.271\end{array}$

$\begin{array}{llllllllll}36.062 & 0.833 & 183.155 & 23.386 & 0.034 & 17.886 & 42.794 & 839.120 & 17.271\end{array}$

$\begin{array}{llllllllll}36.869 & 0.642 & 191.657 & 23.647 & 0.034 & 18.684 & 42.749 & 851.356 & 17.487\end{array}$

$\begin{array}{llllllllll}37.863 & 6.852 & 202.111 & 23.777 & 0.034 & 18.364 & 42.784 & 878.032 & 17.713\end{array}$

$\begin{array}{lllllllll}38.958 & 0.664 & 213.299 & 24.019 & 0.034 & 18.681 & 42.031 & 798.367 & 17.974\end{array}$

$\begin{array}{llllllllll}40.694 & 0.675 & 225.117 & 24.276 & 6.035 & 18.975 & 42.801 & 736.181 & 18.250\end{array}$

$\begin{array}{lllllllll}41.016 & 0.685 & 234.653 & 24.483 & 6.035 & 19.229 & 42.921 & 769.283 & 18.473\end{array}$

$\begin{array}{llllllllll}41.804 & 1.693 & 242.923 & 24.883 & 0.035 & 18.448 & 42.958 & 781.187 & 18.686\end{array}$

$\begin{array}{llllllllll}42.736 & 0.762 & 255.039 & 24.985 & 1.035 & 19.723 & 42.985 & 809.147 & 18.861\end{array}$

$\begin{array}{llllllllll}43.505 & 0.710 & 264.722 & 25.123 & 0.635 & 10.955 & 43.124 & 832.115 & 19.014\end{array}$

$\begin{array}{llllllllll}46.728 & 0.725 & 283.890 & 25.564 & 0.036 & 28.414 & 43.437 & 877.587 & 19.315\end{array}$

$\begin{array}{lllllllllll}48.446 & 0.746 & 361.788 & 26.967 & 0.036 & 28.842 & 43.736 & 920.043 & 19.596\end{array}$

$\begin{array}{llllllllll}47.745 & 0.763 & 318.169 & 26.325 & 1.036 & 21.234 & 43.998 & 958.963 & 18.854\end{array}$

$\begin{array}{llllllllll}48.972 & 0.786 & 333.622 & 28.673 & 1.635 & 21.864 & 44.251 & 995.559 & 28.897\end{array}$

$\begin{array}{llllllllll}49.787 & 0.774 & 343.846 & 28.898 & 1.435 & 21.843 & 44.415 & 1019.339 & 29.255\end{array}$

$\begin{array}{llllllll}0.782 & 353.871 & 27.124 & 1.035 & 22.683 & 44.570 & 1043.110 & 20.412\end{array}$

$\begin{array}{llllllll}0.789 & 361.310 & 27.317 & 0.036 & 22.277 & 44.039 & 1061.023 & 29.628\end{array}$

$\begin{array}{llllllll}6.795 & 387.828 & 27.483 & 0.036 & 22.443 & 45.181 & 1079.103 & 28.621\end{array}$

$\begin{array}{llllllll}6.802 & 376.638 & 27.680 & 0.035 & 22.048 & 45.542 & 1089.583 & 20.738\end{array}$

$\begin{array}{lllllllll}6.868 & 382.645 & 27.846 & 0.835 & 22.896 & 46.883 & 1116.863 & 20.821\end{array}$

$\begin{array}{lllllllll}6.811 & 385.720 & 27.949 & 0.035 & 22.960 & 48.044 & 1128.823 & 26.873\end{array}$

$\begin{array}{llllllll}0.814 & 388.673 & 28.616 & 0.636 & 22.975 & 48.190 & 1134.463 & 20.015\end{array}$

2-69-87 1136

$0.817 \quad 391.982 \quad 28.109$

$\begin{array}{lll}48.190 & 1134.463 & 26.915 \\ 46.398 & 1143.823 & 20.868\end{array}$ 
Lysimeter $\# 10$ field chemistry

Dow Polymer

$\mathrm{Na}_{2} \mathrm{SO}_{4}$ Evaporator Concentrate w/ Ion Exchange Resin

Drum 7-3

CWUATIVE LEACHED,

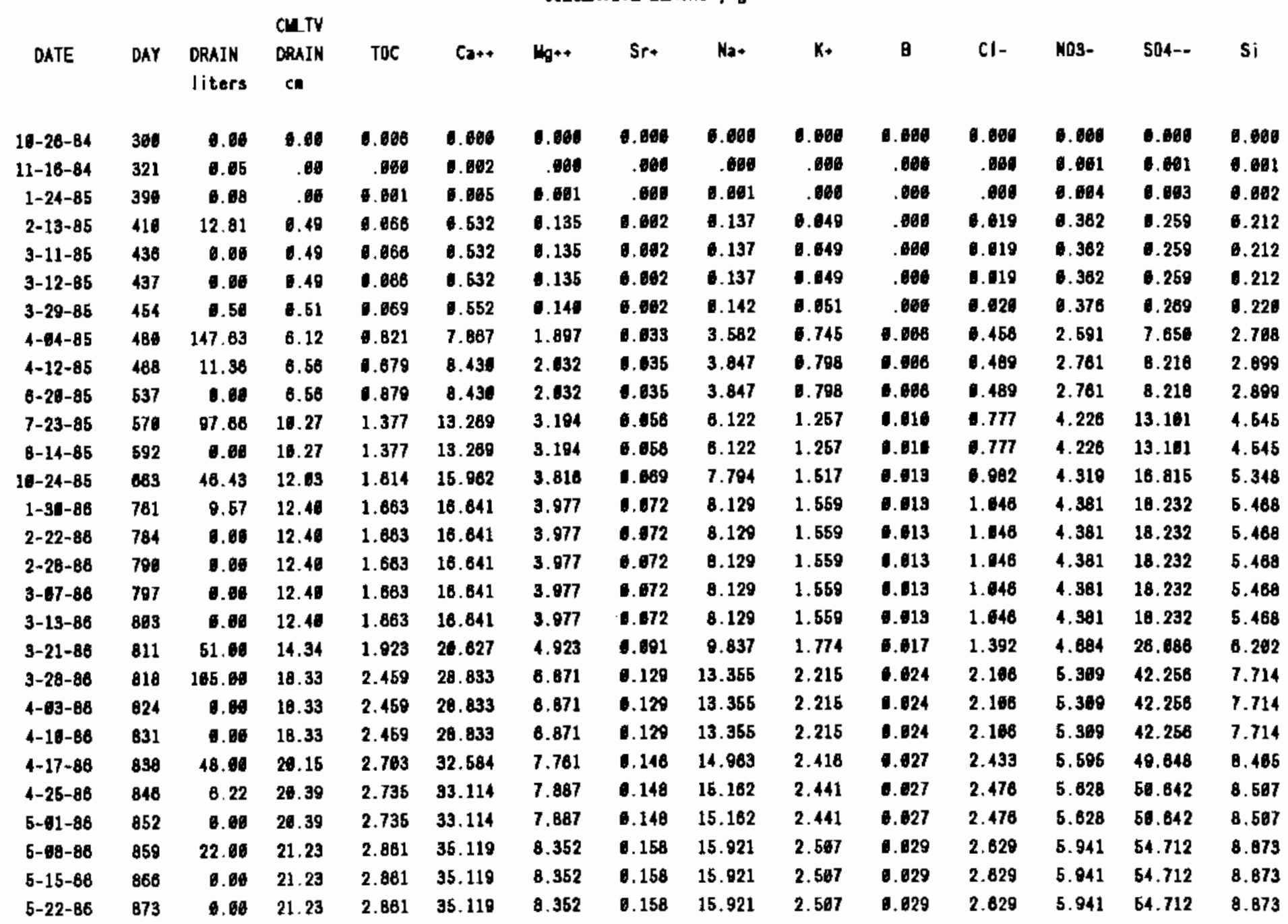


Lysimeter 10 field chemistry (continued)

0ow Polymer

$\mathrm{Na}_{2} \mathrm{SO}_{4}$ Evaporator Concentrate w/ Ion Exchange Res in

Drum 7-3

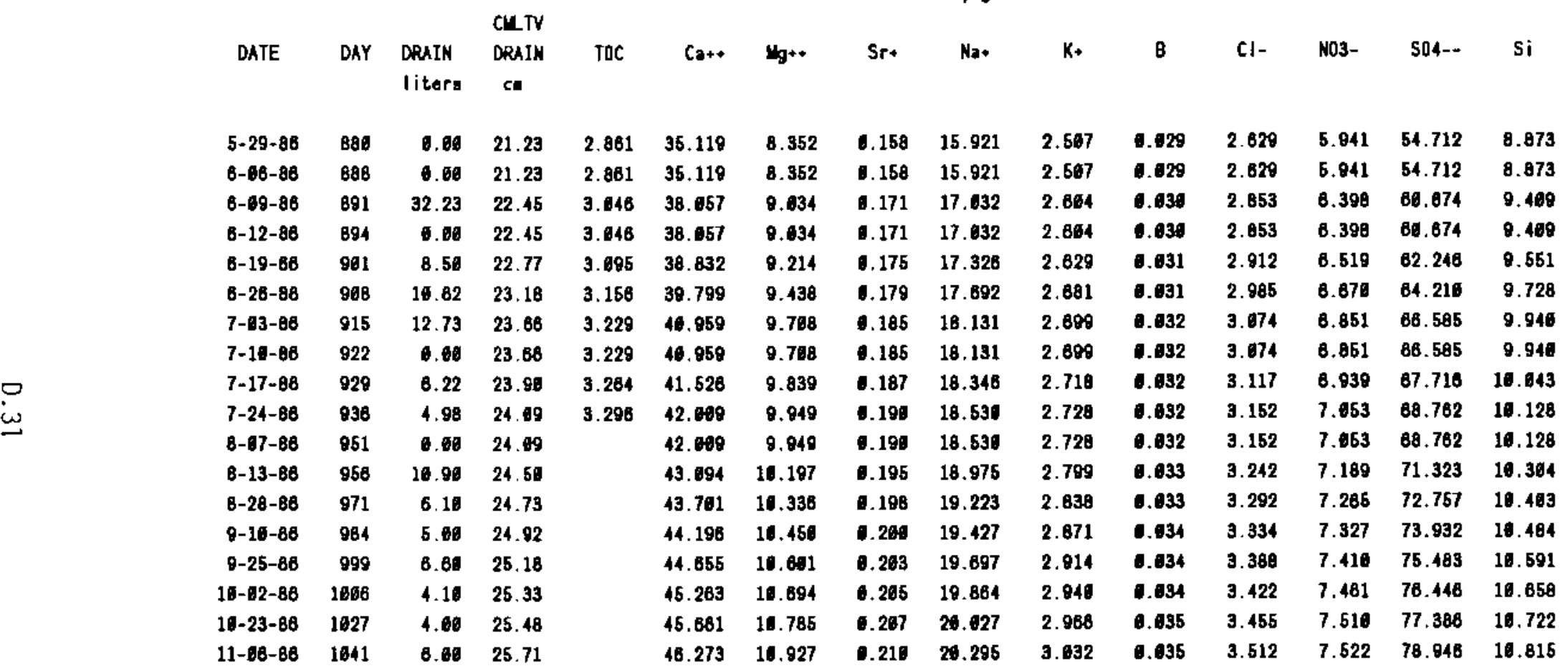

CULATIVE LEACHED, 


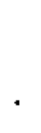

$i$ , 


\section{DISTRIBUTION}

No. of

Copies

OFFSITE

6 Geologic Repository Division DOE Office of Civilian

Radioactive Waste Management Forrestal Building

Washington, D.C. 20585

ATTN: C. R. Cooley, RW-4

J. R. Hilley, RH-40

D. E. Shelor, RW-32

R. Stein, RW-23

J. H. Kale, RW-20

L. H. Barrett, RW-33

3 DOE Office of Defense Waste \& GTN

Byproducts Management

Washington, D.C. 20545

ATTN: R. K. Heusser, DP -123

J. E. Lytle, DP-12

T. C. Chee, DP-123

4 DOE Office of Remedial Action GTN

\& Waste Technology

Washington, DC 20545

ATTN: J. A. Coleman, NE-24

T. W. McIntosh, NE-24

W. R. Voigt, NE-20

H. F. Walter, NE-24

2 DOE Idaho Operations office

550 Second Street

Idaho Falls, ID 83401

ATTN: J. P. Hamric

S. T. Hinschberger

W. J. Brumley

DOE Savannah River Operations Office

P.0. Box A

Aiken, SC 29801
No. of

Copies

F. T. Fong

DOE San Francisco Operations Office

1333 Broadway

0akland, CA 94612

M. R. Jugan

DOE Oak Ridge Operations office

P.0. Box E

Oak Ridge, TN 37830

E. Maestas

DOE West Valley Project Office

P.0. Box 191

West Valley, NY 14171

J. M. McGough

DOE Albuquerque Operations Office

P.0. Box 5400

Albuquerque, NM 87185

10 DOE Technical Information Center

C. S. Abrams

Argonne National Laboratory

P.0. Box 2528

Idaho Falls, ID 83401

M. J. Steindler

Argonne National Laboratory

9700 South Cass Avenue

Argonne, IL 60439

D. B. Shipp

Battelle Memorial Institute Office of Crystalline Repository Deve Topment

9800 South Cass Avenue

Argonne, IL 60439 
No. of

Copies

3 Battelle Memorial Institute Project Management Division $505 \mathrm{King}$ Avenue

Columbus, $\mathrm{OH} 43201$

ATTN: W. A. Carbeiner

W. S. Madia

Technical Library

4 Brookhaven National Laboratory

Nuclear Waste Management Division

Upton, Long Is land, NY 11973

ATTN: $P$. Colombo

M. Fuhrmann

C. R. Kempf

T. Sullivan

2 E. I. du Pont de Nemours Company

Savannah River Laboratory

Aiken, SC 29801

ATTN: E. J. Hennelly

H. F. Sturm, Jr.

6 EG\&G Idaho

P.0. Box 1625

Idaho Falls, ID 83415

ATTN: E. A. Jennrich

D. Halford

J. McConnell

T. Tait

J. Logan

R. D. Rogers

R. Shaw

Electric Power Research Institute

3412 Hillview Avenue

P.0. Box 10412

Palo Alto, CA 94304

J. L. White, Chairman

Energy Research \& Development Authority

Empire State Plaza

Albany, NY 12223
No. of

Copies

Sheldon Meyers

Environmental Protection Agency

Office of Radiation Programs (ANR-428)

401 M Street, S.W.

Washington, D.C. 20460

P. G. Hagan

Joint Integration Office

Carlmont Executive 1

4308 Carlisle, N.E.

Albuquerque, NM 87107

D. T. Oakley, MS 619

Los Alamos Scientific Laboratory

P.0. Box 1663

Los Alamos, NM 87544

3 Oak Ridge National Laboratory

P.0. Box Y

Oak Ridge, TN 37830

ATTN: R. T. Jubin

L. J. Mezga

R. Clapp

4 Sandia Laboratories

P.0. Box 5800

Albuquerque, NM 87185

ATTN: D. R. Anderson

R. W. Lynch

W. Weart

Technical Library

J. R. Berreth

Westinghouse Idaho Nuclear

Co. , Inc.

P.0. Box 4000

Idaho Falls, ID 83401

J. Starmer

U.S. Nuclear Regulatory

Commission

Mail Stop 62355

Washington, D.C. 20555 
No. of

Copies

G. S. Campbel1

Washington State University

Pullman, WA 99164

E. O'Donnell

Earth Sciences Branch

Division of Health, Siting, and Waste Management Research

U.S. Nuclear Regulatory Commission

Washington, D.C. 20555

\section{FOREIGN}

R. W. Douglas Killey

Environmental Research Branch

Health Sciences Division

Chalk River Nuclear Laboratories

Chalk River, Ontario KOJ $1 \mathrm{J0}$

CANADA

\section{ONSITE}

3 DOE Richland Operations Office

E. A. Bracken

N. T. Karagianes

J. R. Hunter

7 West inghouse Hanford Company
N. W. Kirch
H. E. McGuire
K. Owen
T. B. Venziano
D. D. Wodrich
R. D. Wojtosak
R. E. Lerch

No. of

Copies

61 Pacific Northwest Laboratory

W. W. Ballard, Jr.

M. P. Bergeron

J. L. Buelt

D. W. Dragnich

M. J. Fayer

G. W. Gee

M. J. Graham

M. S. Hanson

P. C. Hayes

T. L. Jones (20)

C. T. Kincaid

R. R. Kirkham

V. L. LeGore

W. W. Laity

L. T. Lakey

G. V. Last

C. L. Lindenmeier

J. L. McElroy

W. J. Martin

J. E. Minor

R. J. Serne (10)

R. L. Skaggs

J. A. Stottlemyre

A. P. Toste (4)

Publishing Coordination (2)

Technical Report Files (5) 
